\begin{abstract}
UNIVERSIDADE DE BRASÍLIA
INSTITUTO DE RELAÇÕES INTERNACIONAIS

PROGRAMA DE PÓS-GRADUAÇÃO EM RELAÇÕES INTERNACIONAIS
\end{abstract}

PAULA GOMES MOREIRA

OBSERVAÇÃO INTERNACIONAL DE ELEIÇÕES NA TERCEIRA ONDA: HAITI E MÉXICO EM PERSPECTIVA COMPARADA 
PAULA GOMES MOREIRA

\title{
OBSERVAÇÃO INTERNACIONAL DE ELEIÇÕES NA TERCEIRA ONDA: HAITI E MÉXICO EM PERSPECTIVA COMPARADA
}

\author{
Tese apresentada ao Programa de \\ Pós-Graduação em Relações \\ Internacionais do Instituto de Relações \\ Internacionais da Universidade de \\ Brasília, como requisito parcial para \\ obtenção do título de Doutora em \\ Relações Internacionais.
}

Área de concentração: Política Internacional e Comparada.

Orientadora: Profa. Dra. Maria Helena de Castro Santos 


\section{Catalogação da Publicação}

Instituto de Relações Internacionais da Universidade de Brasília

MM8380 Observação Internacional de Eleições na Terceira Onda: Haiti e México em perspectiva comparada / Paula Gomes Moreira; orientador Maria Helena de Castro Santos. -- Brasília, 2016. $218 \mathrm{p}$.

Tese (Doutorado - Doutorado em Relações Internacionais) -- Universidade de Brasília, 2016.

1. Política Comparada. 2. Observação Internacional. 3. Eleições. 4. México. 5. Haiti. I. Castro Santos, Maria Helena de, orient. II. Título. 


\section{OBSERVAÇÃO INTERNACIONAL DE ELEIÇÕES NA TERCEIRA ONDA: HAITI E MÉXICO EM PERSPECTIVA COMPARADA}

Tese apresentada ao Programa de Pós-Graduação em Relações Internacionais do Instituto de Relações Internacionais da Universidade de Brasília, como requisito parcial para obtenção do título de Doutora em Relações Internacionais.

Aprovada em 16 de dezembro de 2016.

COMISSÃO EXAMINADORA

Profa. Dra. Maria Helena de Castro Santos

Universidade de Brasília (UnB)

Orientadora

Profa. Dra. Norma Breda dos Santos Universidade de Brasília (UnB)

Profa. Dra. Maria Regina Soares de Lima Instituto de Estudos Sociais e Políticos (IESP/UERJ)

Prof. Dr. Rafael Duarte Villa

Universidade de São Paulo (IRI/USP)

Prof. Dr. Luiz Daniel Jatobá França Universidade de Brasília (UnB) 
Dedico este trabalho a minha mãe e a todas as mulheres que se empenham em fazer deste um mundo melhor. 


\section{AGRADECIMENTOS}

Primeiramente, o estímulo maior para escrever esta tese foi o início da minha trajetória de estudos no Instituto de Relações Internacionais, da Universidade de Brasília, na qual tive a oportunidade de frequentar um Programa de Pós-Graduação de excelência na área. Todos os Professores e Funcionários contribuíram enormemente para meu aperfeiçoamento profissional e interpessoal.

Em especial, agradeço à minha maior inspiração intelectual e orientadora, Profa. Maria Helena de Castro Santos, que sempre me apoiou nos momentos necessários e me incentivou.

Também sou grata pelas valiosas lições aprendidas com o Prof. Eiiti Sato por meio de conversas longas e ricas em histórias e estórias.

Ainda no Instituto tive colegas, e hoje mais que isso, amigos, que levarei para a vida acadêmica e fora dela. Amigos, vocês tornaram essa jornada mais terna ao compartilhar seus anseios e medos comigo, e eu com vocês.

É também no meio acadêmico que conheci profissionais excepcionais, que de forma indireta, me auxiliaram na formação de um pensamento crítico na construção da tese. Aí estão inseridos os colegas do Observatório Político SulAmericano (OPSA) com os quais comparti o espírito latino-americano de pensar as relações políticas no continente. Todos (as) foram fundamentais na ampliação do meu modo de entender a região e, posteriormente, de pesquisá-la. Dedico um agradecimento especial à Profa. Maria Regina Soares de Lima, na qual me espelho na docência e pesquisa.

Em termos de pesquisa, ainda, não poderia deixar de citar meu coordenador do Instituto de Pesquisa Econômica Aplicada (IPEA), Guilherme Mendes Resende. Uma mão amiga e alguém que desejo ver crescer cada dia mais pelo ótimo profissional que é, além de um acadêmico mais que merecidamente laureado em sua trajetória.

Fundamental agradecer também o auxílio do amigo da mesma instituição, Wesley de Jesus Silva na parte quantitativa da tese. Seu olhar estatístico contribuiu imensamente para a qualidade do trabalho. Muito obrigada.

Da mesma forma, a convivência com os servidores do Ministério da Integração Nacional, Paulo Pitanga, Morganna Mendes de Oliveira, Thales Alessandro de Carvalho, Katia Yajima Habara, Luisa de Castro Pereira, Luiz Carlos de Lima e Guilherme Castelo Branco Coutinho, me permitiram conhecer mais a visão do governo, me permitiram contribuir em projetos e outros instrumentos de criação de oportunidades, para os países do Sul Global.

Por acreditar que o conhecimento é resultado de muitas experiências, penso ser fundamental citar a acolhida da Associação dos Diplomados da Escola Superior de Guerra (ADESG) de Brasília. A aproximação com o então coordenador da ADESG, Paulo Henrique Fernandes Cavalcante, e com o Coronel Paulo Roberto Laraburu, me abriram novas oportunidades de atuação, às quais sou muito grata. 
Também foi importante a troca com estudantes de outros países no Think Tank da Associação Internacional para os Estudantes de Ciência Política (IAPSS Think Tank), que me permitiu dialogar com outros acadêmicos com visões e perspectivas diferentes sobre o tema da democracia.

O mesmo gostaria de dizer de minha participação em curso realizado pelo Centro Conjunto de Operações de Paz (CCOPAB), no Rio de Janeiro, na qual investiguei um pouco mais do pensamento daqueles que, de fato, puderam acompanhar eleições e outros processos políticos em países com pouca ou quase nenhuma governabilidade. Meu agradecimento pelo amparo no período em que aí estive.

Parte importante do processo de construção da tese não teria sido possível sem minha participação efetiva em missões de observação eleitoral internacionais, de modo que, gostaria de agradecer, inicialmente, ao apoio recebido pelo Instituto Nacional Eleitoral (INE), do México, que me recebeu como uma das visitantes estrangeiras, em um de seus processos eleitorais. Mais ainda, destaco minha participação nas últimas eleições realizadas no Haiti, em que tive a oportunidade, por duas vezes, de ser observadora internacional da Organização dos Estados Americanos (OEA). É com muita satisfação que agradeço a todos os meus companheiros (as) de missão, coordenadores, sobretudo Alexandra Hiraldo; a secretária do chefe da missão, Tenente Sofia Meirose Salles e o chefe da missão o ex-chanceler Celso Amorim, por tudo que compartilhamos e trocamos.

Finalizando, agradeço aos amigos da vida, que me fizeram rir, me escutaram com paciência e compreenderam minha ausência durante o tempo em que estive imersa no meu tema de pesquisa.

Minha ausência foi sentida também pela família, que, apesar de tudo, sempre me apoiou nas minhas decisões, por isso, o agradecimento final vai para minha mãe Waldemarisa, minha irmã Simone e meu companheiro Diogo. Com todo carinho. 


\section{RESUMO}

MOREIRA, Paula Gomes. Observação Internacional de Eleições na Terceira Onda: Haiti e México em perspectiva comparada. 2016. 218 f. Tese (Doutorado) - Programa de Pós-graduação em Relações Internacionais, Universidade de Brasília, Brasília, 2016.

Com esta pesquisa analisamos os impactos do monitoramento internacional de eleições no Haiti e México, através de um índice de boa governança eleitoral, entre os anos de 1990 e 2015. Incialmente foram introduzidos os marcos teórico e conceituais, que guiam o trabalho, e dizem respeito à relação entre a boa governança eleitoral e democracia, traduzidas nas avaliações dos observadores através de quatro visões principais: eleições livres e justas, qualidade das eleições, integridade das eleições e más práticas. A última foi adotada no trabalho como principal eixo analítico, em virtude de abranger as demais perspectivas em sua interpretação dos ciclos eleitorais latino-americanos. Em seguida, foi apresentada a trajetória da prática de observação internacional de eleições, indo desde os referendos e plebiscitos europeus, passando pelas missões multidimensionais da Organização das Nações Unidas e emergência das organizações internacionais e regionais intergovernamentais, também dedicadas ao tema, até sua configuração atual. A terceira parte do trabalho mostra como foi feita a seleção de casos, metodologia utilizada e construção de índice de boa governança eleitoral, além dos principais resultados quantitativos. Os dois últimos capítulos foram dedicados à apresentações e análise dos resultados quanto ao impacto das missões nos períodos do ciclo eleitoral, nomeadamente: pré-eleitoral, durante a votação e pós-eleitoral. Também é demonstrada a variação do índice para cada um dos países, e na conclusão é feita a análise comparativa final.

Palavras-chave: Política Comparada; Observação Internacional; Eleições; Haiti; México. 


\begin{abstract}
MOREIRA, Paula Gomes. International Election Observation of Elections in the Third Wave: Haiti and Mexico in compared perspective. 2016. $218 \mathrm{f}$. Tese (Doutorado) - Programa de Pós-graduação em Relações Internacionais, Universidade de Brasília, Brasília, 2016.

With this research, we analyze the impacts of international monitoring of elections in Haiti and Mexico through an index of good electoral governance between 1990 and 2015. Initially, we introduce the theoretical and conceptual frameworks that guide the work. This conceptual and theoretical frame is based on the relationship between good electoral governance and democracy, reflected in the evaluations of the international observers through four main views: free and fair elections, election quality, election integrity and bad practices. The latter was adopted in the work as the main analytical axis, because it covers the other perspectives in its interpretation of the Latin American electoral cycles. Then, the trajectory of the practice of international observation of elections, ranging from the referendums and plebiscites in Europe, passing through the multidimensional missions of the United Nations and the emergence of international and regional intergovernmental organizations, also dedicated to the theme, until its current configuration. The third part of the thesis shows how the case selection, methodology used and the construction of good electoral governance index were done, in addition to the main quantitative results. The last two chapters were devoted to presentations and analysis of the results regarding the impact of the missions in the periods of the electoral cycle, namely: pre-electoral, during voting and post-election. The index variation for each of the countries is also demonstrated, and at the conclusion is made the final comparative analysis.
\end{abstract}

Keywords: Compared Politics; International Observation; Elections; Haiti; Mexico. 


\section{LISTA DE ABREVIATURAS E SIGLAS}

$\begin{array}{ll}\text { DUDH } & \text { Declaração Universal dos Direitos Humanos } \\ \text { PIDCP } & \text { Pacto Internacional sobre Direitos Civis e Políticos } \\ \text { DPOIE } & \text { Declaração de Princípios para a Observação Internacional } \\ & \text { Eleitoral } \\ \text { ACE Project } & \text { Projeto de Administração e Custo das Eleições } \\ \text { BEC } & \text { Escritório Comunal Eleitoral } \\ \text { BED } & \text { Escritório Departamental de Eleições } \\ \text { BID } & \text { Banco Interamericano de Desenvolvimento } \\ \text { CAPEL } & \text { Centro de Assessoria e Promoção Eleitoral } \\ \text { CARICOM } & \text { Comunidade do Caribe } \\ \text { CC } & \text { Centro Carter } \\ \text { CDI } & \text { Carta Democrática Interamericana } \\ \text { CEP } & \text { Conselho Eleitoral Provisório } \\ \text { CIVPOL } & \text { Polícia Civil do Haiti } \\ \text { CNC } & \text { Confederação Nacional Camponesa } \\ \text { CNE } & \text { Conselho Nacional Eleitoral da Venezuela } \\ \text { CONCANACO } & \text { Confederação de Câmaras Nacionais de Comércio } \\ \text { COPA } & \text { Confederação Parlamentar das Américas } \\ \text { CSE } & \text { Conselho Supremo Eleitoral da Nicarágua } \\ \text { CTM } & \text { Confederação de Trabalhadores do México } \\ \text { DECO } & \text { Departamento para a Cooperação e Observação Eleitoral } \\ \text { DES } & \text { Projeto de Padrões de Eleições Democráticas } \\ \text { DPA } & \text { Departamento de Assuntos Políticos } \\ \text { DPD } & \text { Departamento para a Promoção da Democracia } \\ \text { EAD } & \text { Divisão de Assistência Eleitoral } \\ \text { ECOWAS } & \text { Comunidade Econômica dos Estados da África Ocidental } \\ \text { EMB } & \text { Organismo de Administração Eleitoral } \\ \text { EUA } & \text { Estados Unidos da América } \\ \text { EZLN } & \text { Exército Zapatista de Libertação Nacional } \\ \text { FMI } & \text { Fundo Monetário Internacional } \\ \text { FND } & \text { Front Nacional Democrático } \\ \text { FSI } & \text { Índice sobre Estados Frágeis } \\ \text { HNP } & \text { Polícia Nacional Haitiana } \\ \text { IADC } & \text { Quadro Interamericano Democrático } \\ \text { IDEA } & \text { Instituto para a Democracia e Assistência Eleitoral } \\ \text { IDH } & \text { Índice de Desenvolvimento Humano } \\ \text { IEM } & \text { Norma de Monitoramento Internacional Eleitoral } \\ \text { IFE } & \text { Instituto Federal Eleitoral } \\ \text { IFES } & \text { Fundação Internacional para os Sistemas Eleitorais } \\ \text { IHRLG } & \text { Grupo de Direito Internacional para os Direitos Humanos } \\ \text { IIDH } & \text { Instituto Interamericano de Direitos Humanos } \\ \text { IPSF } & \text { Força Interina de Segurança Pública } \\ & \end{array}$




$\begin{array}{ll}\text { IPU } & \text { União Inter parlamentária Internacional } \\ \text { IRI } & \text { Instituto Republicano Internacional } \\ \text { ISO } & \text { Organização Internacional para Padronização } \\ \text { LTO } & \text { Observador de Longa Duração } \\ \text { MERCOSUL } & \text { Mercado Comum do Sul } \\ \text { MICIVIH } & \text { Missão Civil Internacional no Haiti } \\ \text { MOE } & \text { Missão de Observação Eleitoral } \\ \text { MOEI } & \text { Missão de Observação Eleitoral Internacional } \\ \text { NAFTA } & \text { Tratado Norte-Americano de Livre Comércio } \\ \text { NCDM } & \text { Congresso Nacional de Movimentos Democráticos } \\ \text { NDI } & \text { Instituto Democrático Nacional } \\ \text { NED } & \text { Fundo Nacional para a Democracia } \\ \text { NELDA } & \text { Banco de Dados de Eleições Nacionais em Democracias e } \\ & \text { Anocracias } \\ \text { NRIIA } & \text { Instituto Nacional Republicano para Assuntos Internacionais } \\ \text { OCDE } & \text { Organização para a Cooperação e Desenvolvimento } \\ & \text { Econômico } \\ \text { OEA } & \text { Organização dos Estados Americanos } \\ \text { OIF } & \text { Organizção Internacional da Francofonia } \\ \text { OII } & \text { Organização Internacional Intergovernamental } \\ \text { OING } & \text { Organização Internacional Não Governamental } \\ \text { ONG } & \text { Organização Intergovernamental Internacional } \\ \text { ONU } & \text { Organização das Nações Unidas } \\ \text { ONUVEH } & \text { Grupo de Observadores das Nações Unidas para a } \\ & \text { Verificação das Eleições no Haiti } \\ \text { OPL } & \text { Organização do Povo em Luta } \\ \text { OSCE } & \text { Organização para Segurança e Cooperação na Europa } \\ \text { PAN } & \text { Partido da Ação Nacional } \\ \text { PAN } & \text { Partido da Ação Nacional } \\ \text { PE } & \text { Parlamento Europeu } \\ \text { PIB } & \text { Produto Interno Bruto } \\ \text { PND } & \text { Partido da Nova Democracia } \\ \text { PNR } & \text { Partido Nacional Revolucionário } \\ \text { PNUD } & \text { Programa das Nações Unidas para o Desenvolvimento } \\ \text { PRD } & \text { Partido da Revolução Democrática } \\ \text { PREP } & \text { Programa de Resultados Eleitorais Preliminares } \\ \text { PRI } & \text { Partido Revolucionário Institucional } \\ \text { PRM } & \text { Partido da Revolução Mexicana } \\ \text { PVEM } & \text { Partido Verde Ecologista do México } \\ \text { PVT } & \text { Tabulação de Voto Paralela } \\ \text { SADC } & \text { Comunidade Sul Africana de Desenvolvimento } \\ \text { SIDS } & \text { Pequenos Estados Insulares em Desenvolvimento } \\ \text { STO } & \text { Observador de Curta Duração } \\ \text { TEPJF } & \text { Tribunal Eleitoral e de Poder Judicial Federal } \\ & \end{array}$




$\begin{array}{ll}\text { TSE } & \text { Tribunal Superior Eleitoral } \\ \text { UA } & \text { União Africana } \\ \text { UE } & \text { União Europeia } \\ \text { UNASUL } & \text { União de Nações Sul-Americanas } \\ \text { UNC } & \text { Comando das Nações Unidas na Coreia } \\ \text { UNCOK } & \text { Comissão das Nações Unidas para a Coreia } \\ \text { UNIORE } & \text { União Interamericana de Organismos Eleitorais } \\ \text { UNKURK } & \text { Comissão das Nações Unidas para a Unificação e } \\ & \text { Reabilitação da Coreia } \\ \text { UNOMOZ } & \text { Operação das Nações Unidas em Moçambique } \\ \text { UNTAG } & \text { Grupo de Assistência Transitória das Nações Unidas para a } \\ & \text { Namíbia } \\ \text { UPD } & \text { Unidade de Promoção da Democracia } \\ \text { URSS } & \text { União das Repúblicas Socialistas Soviéticas } \\ \text { USAID } & \text { Agência dos Estados Unidos para o Desenvolvimento } \\ & \text { Internacional } \\ \text { V-DEM } & \text { Índice de Variedades da Democracia } \\ \text { WOLA } & \text { Escritório de Washington para a América Latina }\end{array}$




\section{SUMÁRIO}

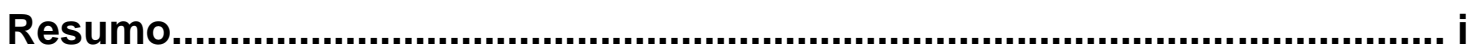

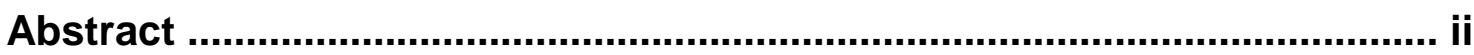

Lista de abreviaturas e siglas....................................................................... ii

Lista de gráficos e figuras..................................................................... viii

Lista de quadros e tabelas................................................................................

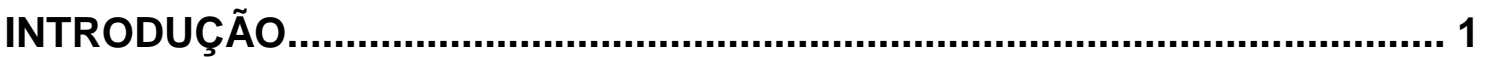

\section{GOVERNANÇA E BOA GOVERNANÇA ELEITORAL: UMA RELAÇÃO}

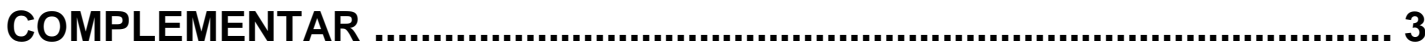

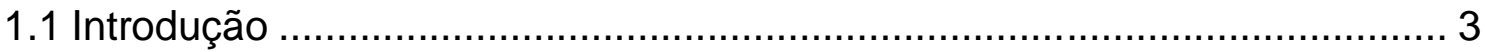

1.2 Governança, boa governança e capacidade governativa: o controle efetivo como estratégia para impulsionar a participação política ................................. 5

1.3 Boa governança eleitoral e as missões internacionais de observação........ 14

1.4 Os diferentes enfoques sobre as boas eleições.......................................17

1.4.1 Eleições livres e justas ......................................................... 18

1.4.2 Qualidade das eleições ...................................................... 24

1.4.3 Integridade eleitoral ........................................................ 28

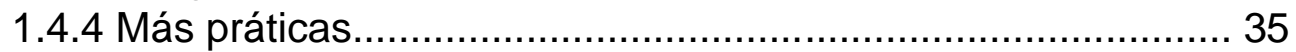

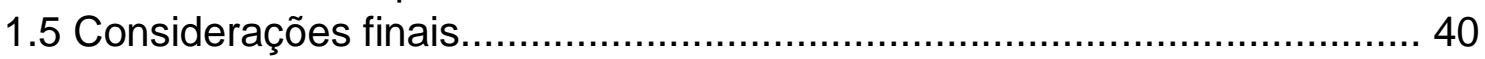

2. DOS REFERENDOS TERRITORIAIS À NORMA DE MONITORAMENTO INTERNACIONAL DE ELEIÇÕES: BREVE HISTÓRIA.................................. 43

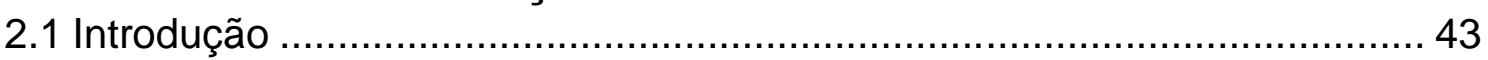

2.2 Fim da Primeira Guerra e reconfiguração do mapa europeu no apogeu dos referendos e plebiscitos territoriais............................................................ 43

2.3 Novos conceitos e novas práticas eleitorais: pós-Segunda Guerra 49

2.4 Avanço da Terceira Onda e criação de novas organizações internacionais

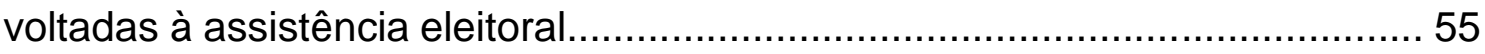

2.5 Expansão do monitoramento internacional de eleições: emergência de

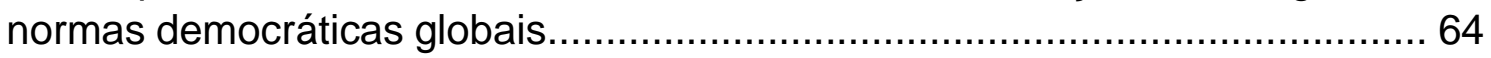

2.5.1 A questão da soberania e os entraves postos às missões internacionais de observação eleitoral............................................ 74 2.5.2 O papel dos observadores internacionais nos sufrágios atuais:

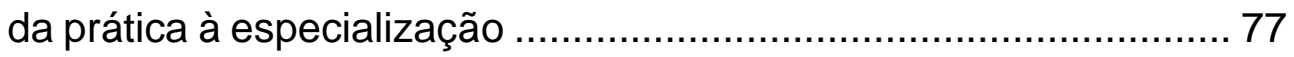

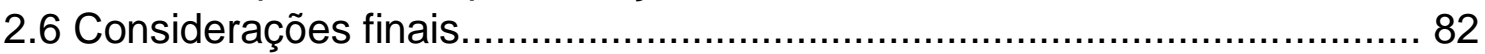

3. IMPACTO DAS MISSÕES DE MONITORAMENTO INTERNACIONAL NA BOA GOVERNANÇA ELEITORAL DO HAITI E MEXICO: MÉTODOS ........... 84

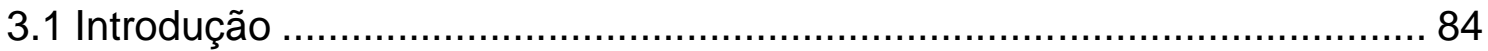

3.20 paradigma de transição como norteador da seleção de casos................. 84

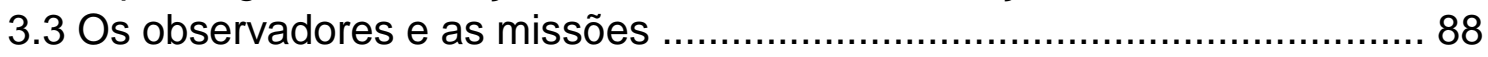

3.3.1 União Europeia ............................................................. 91

3.3.2 Organização das Nações Unidas ....................................... 93 
3.4 Os relatórios das missões e seu uso na avaliação de processos eleitorais. 96

3.5 Haiti e México e sua relação com a observação internacional de eleições. 98

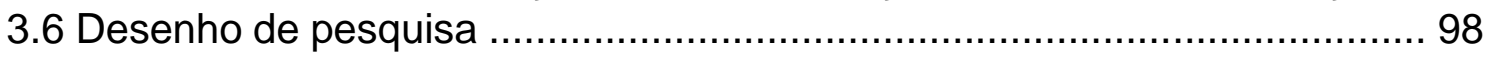

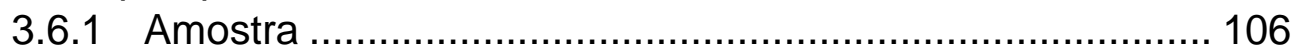

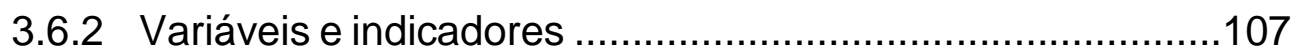

3.6.3 Análise Empírica ............................................................108

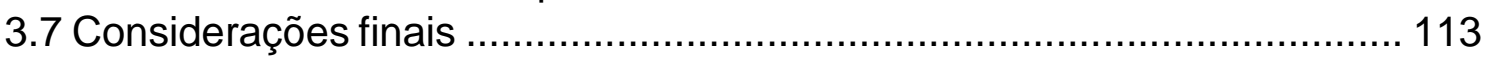

4. LONGA TRADIÇÃO, POUCA EFICIÊNCIA: IMPACTO DAS MISSÕES DE OBSERVAÇÃO ELEITORAL NO PROCESSO ELEITORAL DO HAITI....... 114

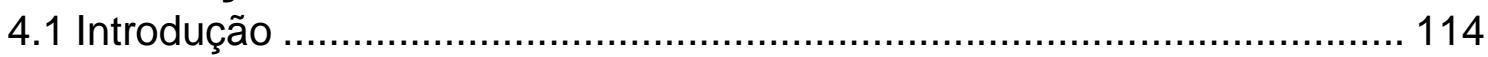

4.2 Observadores nas eleições haitianas: convidar ou não? ........................... 115

4.3 Caracterização do Haiti segundo aspectos socioeconômicos e

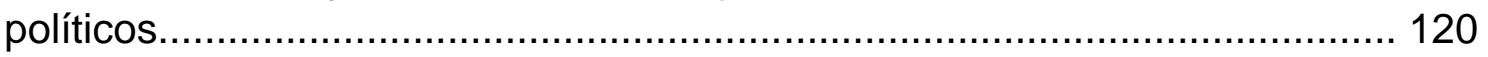

4.3.1 Antecedentes das eleições fundacionais de 1990................. 124

4.4 Primeiras análises: observação desde as eleições fundacionais................ 128

4.5 Impacto das missões de observação: implementação das

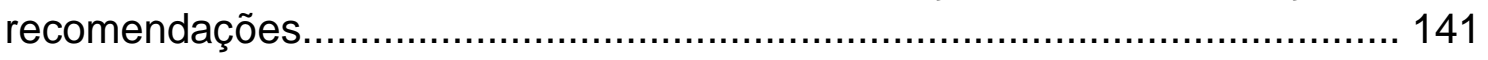

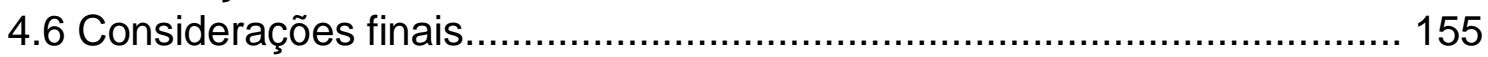

5. RESISTÊNCIA E PERSISTÊNCIA: IMPACTO DAS MISSÕES DE OBSERVAÇÃO ELEITORAL NO PROCESSO ELEITORAL DO MÉXICO.... 156

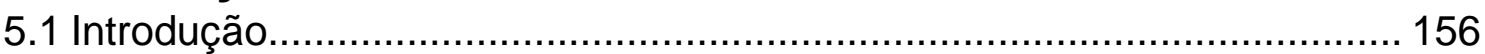

5.2 Caracterização do México e sua cultura política...................................... 156

5.2.1 Da soberania à aderência a normas internacionais democráticas..................................................................... 159

5.3 Primeiras análises: a observação eleitoral a serviço dos interesses políticos

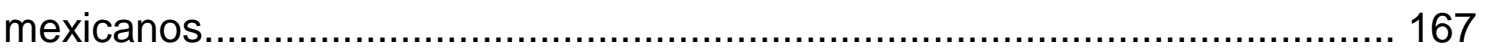

5.4 Visitantes estrangeiros e o impacto das recomendações no sistema eleitoral

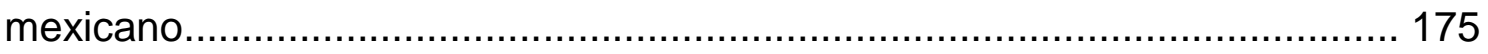

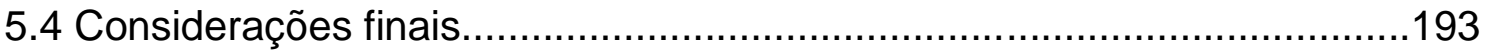

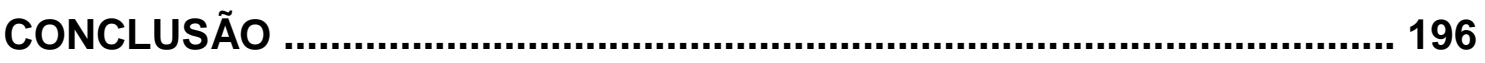

REFERÊNCIAS BIBLIOGRÁFICAS ......................................................201 


\section{LISTA DE GRÁFICOS E FIGURAS}

Figura 1 - O ciclo eleitoral.............................................................. 30

Gráfico 1 - Total de democracias eleitorais no mundo por ano, 1990-201.... 99100

Gráfico 2 - Porcentagem no número de votantes nas eleições haitianas, por ano e tipo $152-153$ 


\section{LISTA DE QUADROS E TABELAS}

Tabela 1 - Percepções sobre as últimas eleições realizadas na América Latina, em países selecionados 80

Tabela 2 - Número total de MOEIs/OEA por década 95

Tabela 3 - A democracia no Haiti e México segundo índices globais de democracia em 2015. 98

Tabela 4 - Classificação como democracia eleitoral, sim ou não, pela Freedom House, do Haiti e México, entre 1990-2015 100

Tabela 5 - Eleições realizadas entre 1990 e 2015 no Haiti e México por ano, data, tipo e organização internacional de observação eleitoral. 107

Tabela 6 - IDH do Haiti, 1990 a 2015 ........................................................120

Tabela 7 - Matriz de observação para o período pré-eleitoral, Haiti 130

Tabela 8 - Matriz de observação pós-eleitorais, Haiti 131

Tabela 9 - Matriz de recomendações para o período pré-eleitoral, Haiti 143

Tabela 10 - Matriz de recomendações para o dia da eleição, Haiti 144

Tabela 11 - Matriz de recomendações pós-eleitorais, Haiti 145

Tabela 12 - Visão geral da taxa de participação popular nas eleições legislativa/parlamentar e presidenciais no Haiti, 1990-2015.

Tabela 13 - Satisfação com a democracia no México, 1995 -

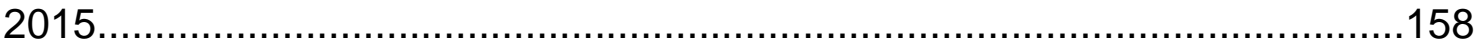

Tabela 14 - Fundos recebidos pela Aliança Cívica, 1994..............................164

Tabela 15 - Matriz de observação para o período pré-eleitoral, México ........168

Tabela 16 - Matriz de observação para o dia da votação, México ...................169

Tabela 17 - Matriz de observação pós-eleitorais, México ................................170

Tabela 18 - Indicadores de recomendações para o período pré-eleitoral, México 177

Tabela 19 - Indicadores de recomendações para o dia da votação, México 178 
Tabela 20 - Indicadores de recomendações pós-eleitorais, México 179

Tabela 21 - Taxa de participação popular nos processos eleitorais mexicanos, por tipo de eleição, data, votos e eleitores registrados, a partir dos anos 2000

Quadro 1 - Lista de verificação das duas principais dimensões de avaliação das eleições com as três fases de observação (antes, durante e após o dia da eleição) 21-22

Quadro 2 - Dispositivos de Direitos Humanos Internacionais em referência a eleições democráticas 25

Quadro 3 - Indicadores de boa governança eleitoral no período pré-eleitoral, dia da eleição e pós-eleitoral $110-111$

Quadro 4 - Classificação das MOEls segundo Índice de Boa Governança Eleitoral (observação e recomendações) $111-112$

Quadro 5 - Índice de Governança Eleitoral, por fase de observação, Haiti 129

Quadro 6 - Índice de Implementação das recomendações das MOEls, Haiti 141

Quadro 7 - Implementação das recomendações das MOEls, Haiti $146-147$

Quadro 8 - Índice de Governança Eleitoral, por fase de observação, México 167

Quadro 9 - Índice de Implementação das recomendações das MOEls, México 176

Quadro 10 - Implementação das recomendações das MOEls, México 181-182 


\section{INTRODUÇÃO}

O envio de observadores internacionais durante o período eleitoral se tornou uma norma internacional democrática, com o fim da Guerra Fria. Isso ocorreu, sobretudo, porque aqueles governos que não convidavam observadores para as suas eleições, passaram a ser vistos, pela comunidade internacional, como autoritários, o que poderia significar maior dificuldade em termos de acordos e negociações, em um mundo cada vez mais liberal e democrático.

Os observadores que podem permanecer por um período mais longo ou mais curto, dependendo de seus mandatos, à semelhança de missões de paz, são enviados aos países que realizarão eleições por organizações internacionais. Muitas dessas organizações têm como um de seus objetivos a promoção da democracia, regime que ganhou força com o advento da Terceira Onda democrática. Elas se especializaram na avaliação da performance dos governos com relação ao cumprimento ou não de determinados critérios desejáveis à boa governança eleitoral.

Embora haja diferenças na forma como as missões de observação internacional atuem, todas têm como objetivo principal contribuir para a construção democrática, sendo que as eleições assumem papel central. Em muitas democracias eleitorais, ou seja, em muitos regimes ainda não consolidados, a observação internacional tem sido desejável, como uma forma de demonstrar internacionalmente, que uma eleição cumpriu com requisitos mínimos para ser considerada democrática.

Não somente isso, como o aumento no número de países que tiveram suas eleições observadas foi impulsionado também pelas mudanças nas condicionalidades impostas pelas agências de financiamento internacional a partir dos anos 1990. Muitas dessas condicionalidades constrangeram os governos a adotarem práticas mais afins à boa governança, inicialmente, e, depois, à boa governança eleitoral. Uma das soluções encontradas pelos governos foi a realização de eleições que contaram com forte componente humano e assistencial internacional. Este comportamento foi mimetizado por uma série de outros governos no mundo, no entanto, é na América Latina, que 
a emergência de um modelo mais especializado de missões de monitoramento internacionais (MOEls) apareceu inicialmente.

A prática da observação também se consolidou na Europa, África, Ásia e, mais recentemente, na América do Norte, assim como se consolidaram as organizações responsáveis por ela.

Não obstante a importância da América Latina para os estudos de observação eleitoral de eleições, a maioria dos países aqui localizados recebe observadores em suas eleições, fato que nos levou a questionar sobre sua relevância como um instrumento na promoção da democracia. Dessa forma, o presente trabalho se debruçou sobre a avaliação do impacto dessas missões para dois estudos de caso, nomeadamente, Haiti e México.

O Haiti possui uma longa história com a observação, tendo os seus primeiros pleitos sido observados de perto por organizações internacionais, que são, nos dias atuais, referências no tema. Assim, desde sua eleição fundacional, em 1990, o país recebe observadores. De outro lado, o México, que durante muitos anos rejeitou a observação, por considerá-la uma ameaça à sua soberania, no entanto, recebeu números recordes de observadores em suas eleições. A observação se tornou um atributo desejável aos últimos governos que convidaram observadores, principalmente, como uma forma de demonstrar externamente, que o país não estava mais sob o domínio de um único partido político.

Como forma de realizar a comparação do impacto da observação (se alto, médio ou baixo) para cada um dos países construímos um índice de boa governança eleitoral, a partir dos relatórios divulgados publicamente pelas MOEls, em que foram agrupados alguns indicadores.

Ainda que a observação seja um fenômeno já consolidado há poucos estudos que de fato se debruçam sobre sua avaliação, de modo que o presente trabalho pretende contribuir para que mais pesquisadores se interessem sobre o tema. Em especial, pretende contribuir para a ampliação da bibliografia existente sobre MOEls, que nos últimos anos, tem sido dominada por autores estadunidenses.

Por fim, esperamos que o trabalho inspire novas gerações de pesquisadores da área de relações internacionais no tema da política internacional e comparada. 


\title{
1. GOVERNANÇA E BOA GOVERNANÇA ELEITORAL: UMA RELAÇÃO COMPLEMENTAR
}

\subsection{Introdução}

O presente capítulo apresenta os conceitos de democracia, democratização, governança, boa governança e boa governança eleitoral.

O conceito inicial de democracia utilizado na tese é o de Schumpeter/Dahl. Os autores definem democracia tendo em vista o momento no qual o processo de decisão ocorre. Schumpeter (1942) problematiza a questão da democracia ao atribuir ao povo, ou conjunto de cidadãos, os fundamentos de legitimação dos pressupostos democráticos na sociedade e no Estado. Na interpretação schumpeteriana:

\begin{abstract}
"A democracia é um método político, isto é, um certo tipo de arranjo institucional para chegar a uma decisão política (legislativa ou administrativa) e, por isso mesmo, incapaz de ser um fim em si mesmo, sem relação com as decisões que produzirá em determinadas condições históricas. E justamente este deve ser o ponto de partida para qualquer tentativa de definição" (idem, p. 296).
\end{abstract}

Schumpeter (1942) propõe que a população ao invés de escolher representantes que expressem suas opiniões passe a escolher os indivíduos que estariam tomando as decisões. Para o autor, a vontade dos indivíduos não é algo ordenado, mas antes, impulsos. Para fazer com que a vontade do cidadão seja um fator político digno de respeito, essa vontade deve, em primeiro lugar, existir e isso é feito mediante a escolha de representantes através do voto. Ou seja, através de uma forma organizada de escolha democrática (ibidem).

Já Dahl amplia o conceito de democracia proposto por Schumpeter mantendo a definição procedural e incorporando outras condições para a democracia moderna. Segundo Dahl (2005), nas democracias os cidadãos devem ter o direito de governar sobre si, ou seja, os indivíduos é que são soberanos, e não o Estado. A soberania deve ser distribuída de forma igual, porque sua desigual distribuição implicaria no fato de que alguns setores da sociedade não são soberanos. De forma que, a igualdade de participação é, portanto, um elemento-chave da democracia, sendo um dos requisitos ao autogoverno como expressão da soberania popular (idem).

A definição de democracia de Dahl traduzida pela poliarquia, requer não somente a igualdade na participação política, mas também competição política 
livre. Assim, para que um sistema político seja democrático e responda às necessidades da população, ele precisa proporcionar igualdade de participação com base na distribuição igualitária de soberania aos cidadãos, que necessitam ter as mesmas liberdades políticas. Devem existir iguais oportunidade de participação em termos de sufrágio, organização de partidos políticos e direito à participação em eleições com competição política (ibidem).

Os regimes variam na proporção da população habilitada a participar de forma mais ou menos desigual, do controle e da contestação à conduta do governo. De modo que

\begin{abstract}
"... uma escala refletindo a amplitude do direito de participação na contestação pública nos permitiria comparar diferentes regimes segundo sua inclusividade. O direito de voto em eleições livres e idôneas, por exemplo, participa das duas dimensões. Quando um regime garante este direito a alguns de seus cidadãos, ele caminha para uma maior contestação pública. Mas, quanto maior a proporção de cidadãos que desfruta do direito, mais inclusivo é o regime. " (Dahl, 2005, p. 3).
\end{abstract}

A repetição contínua de ciclos eleitorais contribui para a realização dos direitos políticos na forma de aumento da participação política, competição mais intensa e intensificação da ideia de autogoverno como algo legítimo. Para Dahl, portanto, a democratização pode se dar através de várias rotas onde as dimensões relativas de contestação e participação aumentam.

As dimensões da contestação e participação são essenciais para a definição dos regimes, que podem assumir características de "regimes híbridos", "autoritarismos eleitorais", entre outros (Collier e Levitsky, 1997). A essas diferentes concepções Collier e Levitsky (1997), denominaram como "democracias com adjetivo". Esta tendência em dar novos nomes e classificações aos regimes que surgiram no imediato pós-Guerra Fria, é consequência do aumento no número de democracias, no mundo. Todas estas novas democracias, com as suas histórias e culturas diferentes, têm o potencial de levar à identificação de uma nova forma democrática (Levitsky e Way, 2002).

Assim, a democracia é mais que eleições, e a democratização é, em parte, garantida com o aumento das qualidades democráticas para além do sistema político. Segundo O'Donnell e Schmitter (1986), qualquer país transitando de um regime autoritário poderia ser considerado em fase transitória para a democracia, sendo que o processo de democratização inclui duas fases: a transição e a consolidação. Para os autores, a transição começa desde o 
momento em que o regime autoritário começa a ruir, até o momento das eleições fundacionais. Após isso, inicia-se a consolidação (idem).

Essa ideia é baseada no argumento de Rustow (1970) de que as transições de regime ocorrem em várias fases, sendo as eleições fundacionais o fim desse ciclo e o início de uma nova era democrática. Dessa forma, as eleições são elemento essencial do processo de consolidação democrática.

Diamond (1996) propõe que a democracia pode variar quanto ao seu grau de democratização, e argumenta que muitos países se encontram em um contínuo entre os extremos de uma democracia completa (liberal) a um autoritarismo fechado, sendo que para esse tipo de classificação as eleições assumem papel centra para determinar em que grau os países se encontram. Collier e Levitsky (1997) também propõem a classificação das democracias com essa variação dicotômica, porém, para os autores, as concepções de democracia variam daquelas mais e menos gerais. O mesmo tipo de classificação também é utilizado pela Freedom House (2016).

Daqueles subtipos de regime democráticos dentro da classificação proposta pela literatura de democratização, estão os chamados regimes semidemocráticos, ou democracias eleitorais, que são "regimes nos quais estão mais ou menos asseguradas eleições inclusivas, limpas e competitivas, porém que falham na manutenção de liberdades civis e direitos políticos que são essenciais à democracia liberal" (Schedler, 2002a, p. 93).

Dentro dessa perspectiva está nosso objeto de estudo, que são as missões de monitoramento internacional de eleições (MOEs), cuja atuação se dá na fase de consolidação democrática, notadamente, em democracias eleitorais.

\subsection{Governança, boa governança e capacidade governativa: o controle efetivo como estratégia para impulsionar a participação política}

De forma inicial, é importante mencionar que a "o desafio da reforma do Estado e seu ajuste à nova ordem econômica e financeira global provocou profusa literatura sobre os conceitos de governabilidade e governança" (Castro Santos, 1997, s. p.). O tema da governabilidade passou a estar em primeiro 
plano dos debates acadêmicos e políticos e era uma alternativa às teorias dominantes sobre modernização e desenvolvimento político.

A partir daí o foco das preocupações deixaram de estar focadas no problema da construção democrática, passando a ter como eixo principal a questão da estabilidade política ou, mais especificamente, da governabilidade. Muitas das análises de governabilidade, interpretada como fruto dos excessos de participação e sobrecarga de demandas, no contexto das democracias consolidadas, derivaram dos trabalhos seminais de Samuel Huntington nos anos 1960 e 1970. Segundo o autor, a saída para o excesso e sobrecarga mencionados está no reforço e criação de instituições e da autoridade governamental (idem).

No mesmo período surge uma segunda geração de análises sobre governabilidade e as crises de governabilidade derivadas das tentativas de sustentação das políticas de ajuste em ambientes democráticos. O Banco Mundial e o Fundo Monetário Internacional lideraram esse debate que teve também, muitas das agências internacionais de financiamento, como maiores expoentes (ibidem).

À governabilidade seria atribuída um conteúdo eminentemente normativo ou programático, do ponto de vista das instituições multilaterais. Tornando a governabilidade sinônimo de "capacidade dos governos de conjugar simultânea e eficientemente as 'market friendly reforms' com a criação de condições institucionais capazes de estabilizar as expectativas dos decisores econômicos" (idem, p. 4).

Para Fiori (1995), a governança aumentava o detalhamento do que seria um governo pequeno, bom e, sobretudo, confiável do ponto de vista da comunidade internacional, em contrapartida à fragilidade de sistemas políticos, com instituições pouco sólidas, políticas incertas e variáveis e falta de uma estrutura legal sólida. Assim, o conceito de governança apareceu ligado "às características que estão geralmente associadas a um sistema nacional de administração" (Weiss, 2000, p. 795), que, em outras palavras, significa o método, forma ou maneira de governar.

Para Bøås (1998), governança corresponderia à "forma como indivíduos e instituições, públicas e privadas, administram seus assuntos em comum" ( $p$. 120). Sendo que, "a governança claramente engloba instituições 
governamentais, mas ela também subsume organizações informais, e instituições não governamentais que operam na esfera pública" (idem). A governança pode ser entendida, de um modo geral, como o processo decisório ou procedimento através do qual os governantes decidem quais serão as suas políticas governamentais com vistas à melhoria do bem-estar e condições de vida dos cidadãos (ibidem).

Governabilidade ou boa governança passaram a ser sinônimo ou resultado da capacidade dos governos de realizarem reformas, atendendo às demandas dessas agências. Segundo Castro Santos (1997), a capacidade governativa existe quando um sistema político produz políticas públicas que resolvam os problemas da sociedade ou, em outras palavras, quando consegue converter o potencial político de um dado conjunto de instituições e práticas políticas em capacidade de definir, implementar e sustentar políticas.

Interessante notar que mesmo governos autoritários podem ter capacidade governativa. No entanto, é somente nas democracias que há espaço para reformas e promoção da boa governança. Isso ocorre porque o comprometimento com reformas nas instituições e sua execução requerem um mínimo de liberalização política, existente apenas em um ambiente democrático. Além disso, accountability ${ }^{1}$, participação e construção de consenso, elementos da capacidade governativa, só podem ser plenamente desenvolvidos em um sistema democrático" (idem, p. 3).

A definição teórica e prática de governabilidade foi sendo redefinida, até que em 1990, surgiu o termo "boa governança", que passou a ser visto com mais frequência nas agendas de pesquisa e em outras atividades subsidiadas por bancos públicos e/ou privados e agências de financiamento internacionais. Estas últimas passaram a condicionar sua ajuda externa à performance dos países

\footnotetext{
1 Accountability é entendido aqui como um conceito bi-dimensional. De um lado, indica a responsabilidade do Estado em responder a demandas, dar informações e explicações para as medidas que realiza em nome da boa governança. Se traduz na forma de obrigar o poder público a ser coerente nas ações a que se propõe realizar. De outro lado, representa a possibilidade do Estado ser punido caso não haja com coerência. Significa dizer, por exemplo, que as instituições podem tomar medidas para punir seus executores. No caso das eleições, corresponderia à capacidade dos eleitores de ter suas demandas atendidas, e, quando isso não ocorre, ou seja, quando seus direitos são violados, tem-se a possibilidade de punir os eleitos através de sua deposição, por meio do voto. Segundo a própria definição da União Inter Parlamentária (1997, Ponto 14): "a responsabilidade pública implica um direito de acesso do público a informações sobre as atividades do governo, o direito de petição ao governo e de obter reparação através de mecanismos administrativos e judiciais imparciais".
} 
receptores em termos de sua "boa governança", utilizando-se do princípio da "seletividade"2". Ou seja, a retomada do crescimento econômico per se garantiria o desenvolvimento de instituições democráticas, existindo ainda a expectativa de que "o auxílio ao desenvolvimento fosse usado de forma efetiva" (Nanda, 2006, p. 270). Este foi o modo encontrado pelas agências financeiras multilaterais para obrigar os países destinatários a demonstrar seu compromisso com reformas econômicas pró-mercado e políticas pró-instituições democráticas (idem).

Segundo Fiori (1995), tanto no meio acadêmico quanto nas agências multilaterais, os termos governabilidade e reformas estruturais passaram a ser definidos, de forma dependente, uma vez que "a governabilidade era condição das reformas como estas eram o caminho mais seguro para consolidar a própria governabilidade" (p. 5). Assim,

"Em meados dos anos 1990 e nos anos subsequentes, a chamada
[neoliberal] para que houvesse menos Estado passou a ser substituída
por uma chamada para um melhor Estado. Esta nova abordagem não
deve ser confundida com um apelo ao retorno do Estado forte
(keynesiano ou socialista). Pelo contrário, implica uma melhor e mais
transparente governança do que restou do Estado depois da
implementação da reestruturação neoliberal. Muitas vezes, a ênfase na
boa governança foi combinada com um chamado pela
democratização" (Demmers et al, 2005, p. 1)

Bøås (1998) complementa que

"O chamado à boa governança de instituições financeiras internacionais bilaterais e multilaterais é, ao menos implicitamente, um chamado a liberalização econômica, democratização, accountability e respeito aos direitos básicos dos indivíduos. É uma tentativa de promover os direitos políticos" (idem, p. 119).

Para Weiss (2000), a boa governança surgiu como resposta a uma "má governança", muitas vezes associada aos regimes autoritários, nos quais estavam presentes a personificação do poder na figura de um líder, a inexistência de direitos humanos, a corrupção entre os governantes, além de governos ilegítimos, ou seja, não eleitos por voto popular.

Bøås (1998) concorda com este argumento ao indicar que o Banco Mundial também vê a boa governança como o oposto da má governança. A boa governança seria capaz de "garantir não somente a legitimidade de um governo,

\footnotetext{
${ }^{2}$ Seleção de áreas nas quais os financiamentos seriam aplicados.
} 
como também conferir legitimidade aos decisores" (p. 120), de forma que, esse conceito passaria a incluir temas como maior transparência, prestação de contas, representação e justiça nos países em desenvolvimento, com incorporação do político ao econômico através das reformas demandadas pelas agências multilaterais. O Banco Mundial interpretou a boa governança como os meios que devem ser empregados por um governo para melhor eficiência do serviço público, promoção da efetividade do setor judiciário, respeito pelos direitos humanos e defesa de uma estrutura pluralística institucional (Banco Mundial, 1994).

Já o Fundo Monetário Internacional (FMI) associa boa governança a práticas que potencialmente impactem a performance econômica de um país, promovendo maior transparência e regulação do ambiente econômico. Para que reformas na governança deem certo é necessário que sejam respeitadas a cultura e história dos países receptores da ajuda externa. Contudo, "os objetivos do Fundo sobre a governança não são bem definidos e nem articulados" (Nanda, 2006, p. 277), sendo mais voltados à gestão econômica tradicional com vistas ao reforço da confiança do mercado.

O governo dos Estados Unidos é importante doador e tem sua política de ajuda baseada no princípio da seletividade. Subjacente a suas ações e programas de ajuda está a crença nos laços entre democratização e crescimento econômico. Além do mais, no âmbito de suas atividades de promoção da democracia e boa governança estão previstos o respeito ao Estado de direito, eleições e processos político-democráticos e fortalecimento da sociedade civil (idem, p. 279).

A ONU tem utilizado a boa governança como um conceito organizacional para seu maior envolvimento em uma série de operações, de construção e/ou manutenção da paz. Dessa forma, o conceito definido pelo Programa das Nações Unidas para o Desenvolvimento (Pnud) (1997), denota a boa governança, de uma forma geral, como o exercício de autoridade econômica, política e administrativa na condução de um país em todos os seus níveis. Ela engloba mecanismos, processos e instituições através das quais os cidadãos e grupos articulam seus interesses, exercem direitos legais, conhecem suas obrigações e mediam diferenças. 
De forma mais precisa, a organização vê a boa governança por meio de um modelo de oito pontos principais, que incluem: participação; consenso orientado; accountability; transparência, responsividade, efetividade; eficiência e equidade com inclusão. Conforme tal visão, a Organização crê que há diminuição nos níveis de corrupção e ampliação na participação de minorias em processos decisórios, principalmente em democracias, mas não somente nestas, podendo englobar ainda outras formas de governo.

Em 1992, o secretário-geral das Nações Unidas, Boutros Boutros-Ghali, no documento "Uma Agenda para a Paz", enfatizou o papel da participação política como um fator necessário à estabilidade política de um país e seu desenvolvimento. Para ele, a democracia requer uma compreensão mais profunda dos direitos das minorias e das necessidades dos grupos mais vulneráveis da sociedade. De modo que "a estabilidade social necessária ao crescimento produtivo seja nutrida por condições nas quais as pessoas possam expressar sua vontade. Para isso, instituições domésticas fortes são essenciais" (Boutros-Ghali, 1992, § 82).

O secretário-geral enfatizou a ligação entre participação popular, democracia e desenvolvimento em documento suplementar, no ano de 1994. Na "Uma Agenda para o Desenvolvimento", ele diz que a promoção de maior participação popular nas democracias aumenta a probabilidade de que os projetos de desenvolvimento reflitam as aspirações e prioridades sociais (Boutros-Ghali, 1994, § 128).

No seu último documento à frente da liderança das Nações Unidas, denominado "Uma Agenda para a Democratização" (1996), Boutros afirma que é necessária a existência de um Estado que seja capaz não somente de criar as condições mínimas para a realização de eleições livres e justas, como também de dar suporte ao desenvolvimento e manutenção de instituições necessárias à prática da democracia (Boutros-Ghali, 1996, § 16). Padilla e Houppert (1993, p. 76), dizem que: "assim como a transição para uma democracia requer escolhas livres e justas sobre aqueles que irão governar, escolhas livres e justas requerem que a democracia implemente os direitos que ajudou a garantir". Com esse documento o secretário geral finaliza sua gestão, indicando sua crença em um maior consenso sobre a governança democrática como um instrumento para a 
preservação da paz e segurança, justiça social e direitos humanos, assim como para a promoção do desenvolvimento social e econômico (Goodwin-Gill, 2006).

Para o atual secretário das Nações Unidas, Kofi Annan, a boa governança está na garantia do respeito aos direitos humanos e no estado de direito; fortalecimento da democracia; promoção da transparência e responsabilidade na administração pública (Weiss, 2000).

Como se pode perceber, o tema da boa governança passou a ganhar mais força no âmbito da ONU, ao mesmo tempo em que crescia o respeito e alcance dos direitos humanos no mundo. Como consequência, identifica-se uma preocupação maior, não apenas quanto ao resultado das eleições, mas também quanto a sua condução. Esta passa a ser avaliada no que se refere ao seu impacto na representatividade e accountability do governo alvo.

A Organização para a Cooperação e Desenvolvimento Econômico (OCDE) também percebe a governança como o uso da autoridade política e exercício do controle em uma sociedade com relação a seus recursos existentes com vistas ao desenvolvimento social e econômico. Esta definição abrange o papel de autoridades públicas no estabelecimento de um ambiente favorável aos operadores econômicos ao mesmo tempo em que prevê a distribuição de benefícios em um dado país. Assim, para além da definição baseada nos mecanismos que garantem a boa governança, na visão da OCDE está previsto o alcance de resultados, no sentido de que todos, independentemente de seu status social ou econômico, teriam voz no governo e receberiam tratamento equitativo (OCDE, 1995).

Nanda (2006) argumenta que não há parâmetros universais que determinem o que é a boa governança, ainda que a maioria das definições incluam aspectos como estabilidade política, controle da corrupção e accountability.

Demmers et al (2005) defendem que há pelo menos três diferentes visões sobre o desenvolvimento no que concerne a questão da boa governança. A primeira visão dominante sobre o desenvolvimento se dá a partir de um ponto de vista administrativo ou tecnocrático. Seus principais elementos são: eficiência, autoridade e accountability do Estado. Para que se possa contribuir ao desenvolvimento é necessário realizar mudanças qualitativas a exemplo do 
combate à corrupção e maior transparência política. Como consequência, haverá crescimento econômico.

A segunda abordagem é mais ampla e considera a redução da pobreza como principal objetivo do desenvolvimento, sendo a boa governança um meio para alcança-lo. Há ênfase no efetivo papel desempenhado pelas instituições responsáveis pelo tema da pobreza e também na participação popular no âmbito destas.

Por fim, tem-se a perspectiva da boa governança em referência aos direitos humanos e democracia, que é a mais atual e é a adotada neste trabalho. O que se vê é a defesa de práticas que garantam: separação de poderes; um poder judicial independente; liberdade de organização; expressão e de imprensa, eleições livres e sistema político multipartidário. Dessa forma, a sociedade tem grande importância não somente através da participação, mas também na condução das forças políticas para um desenvolvimento equitativo. "O desenvolvimento é compreendido como algo que engloba processos econômicos, socioeconômicos e políticos, que ocorrem simultaneamente" (idem, p.3).

O tema ganhou relevância em início dos anos 90 durante a Terceira Onda de Democracia (Huntington, 1994), uma vez que muitos países em desenvolvimento e da antiga União Soviética (URSS) estavam envolvidos nesta onda de transições democráticas ${ }^{3}$. Segundo Weiss (2000, p. 799), “a democratização generalizada, incluindo o monitoramento de eleições pelas Nações Unidas em antigas ditaduras (...), trouxe o foco diretamente para as condições e qualidade da governança local". Dessa forma, países antes autoritários passaram a adotar governo civil, eleições e democracia multipartidária como uma forma de atrair financiamento internacional, tendo as eleições sido a condição principal para tais mudanças (idem).

Também contribui para a ênfase nas eleições, a proliferação de atores não-estatais em locus nos quais somente o governo atuava. Grupos de direitos

\footnotetext{
3 Transição democrática é a primeira fase do processo de democratização, correspondendo ao período entre o final do regime autoritário anterior e o início da fase de consolidação da nova democracia. Em geral termina quando se promove as chamadas eleições fundacionais (cf. O'Donnell and Schmitter, 1988). Para Przeworski (2015, p. 105) uma transição democrática ocorre quando: "uma primeira eleição competitiva é realizada após um período em que as eleições não foram realizadas ou foram contestados ou foram tão manipuladas que a oposição não tinha chance de ganhar".
} 
humanos, redes transnacionais de comunicação ou mesmo a atuação de grandes multinacionais, fizeram com que "políticas sociais e econômicas não fossem mais somente uma questão exclusiva dos governos" (idem, p. 800)

Como consequência, a boa governança se tornou uma condicionalidade política e econômica inseparável dos debates sobre financiamento bilateral e multilateral aos países em desenvolvimento ou antigos territórios do bloco socialista. O PNUD, por exemplo, passou a oferecer, nos últimos anos, não somente ajuda econômica, como ainda, assistência em áreas sensíveis à boa governança, como direitos humanos e apoio a reformas no Legislativo. Em países que experimentaram algum tipo de transição política, o Programa passou a realizar também assistência eleitoral, de modo a diversificar suas ações conforme novas demandas surgiram. A maioria dos esforços internacionais, têm, assim, nos últimos anos, apoiado a democratização (aí incluídas eleições, accountability e direitos humanos) junto à liberalização econômica.

Além disso, conforme Chauvet e Collier (2009, p. 512), "o eleitorado, mais que os doadores internacionais, passaram a condicionar os governos a adotarem uma boa performance. Os autores estabeleceram uma correlação entre os efeitos cíclicos da realização de eleições em países em desenvolvimento. Para eles, eleições frequentes levam a melhores políticas, enquanto se ocorre diminuição na frequência entre um processo eleitoral e outro os bons efeitos diminuem. Da mesma forma, se uma eleição é má conduzida ela perde sua eficácia estrutural, podendo vir a ser algo contra produtivo. Os governos que utilizam meios ilícitos (ou de má governança) para vencer um processo eleitoral, tais como suborno, fraude eleitoral e intimidação de eleitores, tenderá a recorrer a políticas ruins para manter seu governo. Em outras palavras, "uma eleição que não é 'livre e justa' é uma tecnologia que não funciona: uma vez que não se pode esperar que o governo seja responsável para com seus cidadãos" (p. 539). No centro da promoção da democracia, portanto, estava a promoção de eleições".

Há que se destacar, ainda, que os doadores internacionais adotam padrões internacionais de boa governança eleitoral, estabelecendo, como condição para a ajuda econômica aos países-alvo, alguns padrões mínimos de accountability ou de responsabilidade pública, sendo as eleições uma parte importante dessas exigências. 
Para Pereira (2006), ainda que existam diversas definições de boa governança formuladas por organizações internacionais e acadêmicos, quatro pontos principais (ou padrões mínimos) são recorrentes, sendo eles: (1) o fato de que a boa governança tem como base principal a constituição; (2) práticas administrativas efetivas e eficientes, com ausência de corrupção e sem partidarismos; (3) políticas que de fato representam a vontade popular e; (4) um governo representativo. Assim, "as eleições são vistas como o elemento mais comum para garantia da representatividade e accountability de um governo. A boa governança é reflexo da democracia" (idem, p. 16).

Pode-se concluir do exposto acima, que atualmente a boa governança e democracia são conceitos intimamente ligados. Hoje, diferentemente de algumas décadas atrás, as agências multilaterais de desenvolvimento necessariamente incluem condicionalidades de boa governança.

\subsection{Boa governança eleitoral e as missões internacionais de observação}

Elklit e Reynolds (2005) afirmam que só recentemente a literatura acadêmica de democratização começou a reconhecer que questões de governança devem abranger o tema da realização de eleições, tanto nas democracias consolidadas, quanto naquelas emergentes. Da mesma forma, Carothers (1997), Diamond (2004) e Levitsky e Way (2002) complementam que apesar da rede de organizações internacionais empenhadas no monitoramento de eleições e de democracia eleitoral já ter se expandido há algum tempo, existe dificuldade nas áreas de política e relações internacionais em reconhecer a importância de estudos sobre governança eleitoral para a consolidação democrática.

É somente com o aumento a preocupação com a credibilidade dos resultados eleitorais das democracias da Terceira Onda democrática, que o tema ganhou destaque na literatura de política comparada. Sendo que, a preocupação básica desses novos governos era, principalmente, assegurar que os resultados das urnas fossem justos, transparentes e aceitos pelos candidatos e partidos em disputa (Huntington, 1994). 
Somado a isso, Kelley (2012) ressalta a maior aproximação entre democracia e boa governança, como critérios importantes para a comunidade de doadores internacionais, o que contribuiu para ampliação no número de eleições realizadas em países em desenvolvimento, dependentes desses recursos. Segundo a autora, os governos desses países passaram a convidar monitores internacionais como forma de demonstrar que estavam comprometidos com as reformas estruturais impostas pelas agências de financiamento internacionais, de forma a evitar que seus benefícios fossem retirados. A autora cita o caso do autogolpe no Peru, em 1992, quando o "Fundo Monetário Internacional (FMI) e o Banco Mundial cortaram a ajuda econômica do país e forçaram Fujimori a realizar eleições parlamentares com observadores internacionais" (p. 29).

Da mesma forma, um governo instável ou em transição pode solicitar a observação como forma de obter aprovação doméstica, comprovando que as eleições não foram fraudadas. Mesmo países já consolidados podem solicitar a observação como forma de manter sua credibilidade ou reforçando-a (idem).

Para Bachelard (2010, p. 6), "a liberdade e justiça de um processo eleitoral são determinados pela relativa força a favor, e contra, a boa governança eleitoral. Sendo que influências positivas e negativas podem advir tanto de atores nacionais, quanto de atores internacionais". Essa asserção, no entanto, é mais forte nos casos em que a democratização é ainda frágil, e em que a independência dos organismos eleitorais é fraca, sendo o jogo eleitoral a parte central da política de um país em desenvolvimento (idem).

Partindo da noção de que em uma dada democracia há sempre a possibilidade desta ser aprimorada, e que eleições podem ser cada vez mais livres e justas, Hartlyn \& McCoy (2006) defendem, conforme uma extensiva literatura em observação eleitoral, que as eleições podem ser avaliadas a partir de duas perspectivas iniciais: a primeira, conforme sua legitimidade, que corresponderia a aceitação por parte de atores centrais no processo eleitoral de que a votação foi livre e justa e, a segunda, pela visão da qualidade.

Assim, Mozaffar (2002, p. 87-88) argumenta que:

"A legitimidade de uma eleição competitiva tem como base a institucionalização de uma certeza processual que assegure uma incerteza substantiva. Atores políticos irão aceitar o que está por vir se eles tiverem certeza de que as regras na organização da competição 
não irão determinar seus resultados. As regras da governança eleitoral proveem essa certeza processual ${ }^{4}$.

Precisamente porque a governança eleitoral implica a organização de incerteza eleitoral, e, portanto, a prestação de certeza processual que serve de base para 'eleições livres e justas', a formulação e implementação de regras sobre a governança eleitoral é de particular preocupação para os atores políticos nas democracias emergentes".

Mozaffar e Schedler (2002) concordam com estas ideias, porém, para eles, uma efetiva governança eleitoral não é feita somente através da garantia de boas eleições, pois uma série de variáveis política, econômica e sociais afetam o processo, integridade e resultados de uma eleição democrática. "Mas boas eleições são impossíveis sem uma efetiva governança eleitoral” (p. 6).

A boa governança eleitoral resulta de: (1) interação de normas constitucionais, legais e institucionais e práticas organizacionais que determinam as regras básicas para os procedimentos eleitorais e competição eleitoral; (2) organização de campanhas, registro de eleitores, e contagens no dia de eleição; e (3) resolução de disputas e certificação dos resultados (idem) ${ }^{5}$.

Com a mesma abordagem, Mozaffar e Schedler (2002, p. 7) conceituam a governança eleitoral como " o abrangente número de atividades que cria e mantém o amplo arcabouço institucional no qual se realizam o voto e a competição eleitoral. Ela opera em três diferentes níveis: formulação de regras (rule making), aplicação de regras (rule application) e atribuição de regras (rule adjudication)".

O nível de formulação de regras (rule making) consiste na escolha e a definição das regras básicas do jogo eleitoral. Envolve o contexto constitucional, código eleitoral e toda a legislação relativa ao processo eleitoral que será realizado, definindo, por exemplo, quem são os candidatos habilitados a concorrer, assim como os eleitores habilitados a votar; definição de datas, em que a jornada eleitoral irá ocorrer e outras questões legais.

A aplicação de regras (rule application) corresponde à implementação, organização e gerenciamento do processo eleitoral, que engloba procedimentos

\footnotetext{
${ }^{4}$ Cf. Schedler (2002a), deve haver certeza processual, porém incerteza quanto aos resultados finais, uma vez que partidos políticos, conforme integridade eleitoral, são livres para competir entre si. Em outras palavras, a governança eleitoral teria como tarefa central institucionalizar a incerteza sobre o resultado da sucessão que deve existir em ambientes democráticos

${ }^{5}$ Para Elklit e Reynolds (2005) a governança eleitoral só tende a atrair a atenção quando ao longo de algum processo de decisão, surgem controvérsias. Em outras palavras, quando todo o processo ocorre conforme critérios mínimos de qualidade não são observados divergências por parte da oposição ou de outros agentes envolvidos nas eleições.
} 
de preparação da votação, a exemplo da realização do credenciamento de eleitores e candidatos; perpassando jornada eleitoral, com a tarefa de coleta dos votos e; se encerrando com a tabulação dos votos, publicação dos resultados e diplomação dos eleitos.

Por fim, há o nível de atribuição de regras (rule adjudication), que diz respeito à administração dos litígios que possam surgir entre os competidores, com relação ao processo eleitoral, em todas as suas fases.

A garantia de que um processo eleitoral atendeu aos requisitos colocados advém da existência de critérios básicos ao longo de todo o processo de escolha, como a liberdade de competição entre partidos políticos e seus candidatos; a existência de campanha política; a publicação de resultados de acordo com a vontade popular; além de ser um processo confiável, uma vez que o organismo eleitoral responsável pela condução da votação é visto como imparcial; entre outros (Elklit \& Reynolds, 2005; Schedler, 2002; IDEA, 2002; Muñoz-Pogossian \& Veloso, 2015).

Assim, todos esses critérios apresentados estão de acordo com os princípios previstos para o bom funcionamento da governança eleitoral. Cabe agora, definir o que representa uma boa eleição, dentro da visão da boa governança eleitoral, identificando os diferentes pontos de vista existentes.

\subsection{Os diferentes enfoques sobre as boas eleições}

Nas democracias eleitorais os processos de sucessão devem cumprir com uma série de requisitos para que seus resultados sejam respeitados. Entre estes: eleições livres e justas, resultados incertos; vários candidatos em competição. Problemas podem vir a surgir, uma vez que "eleições perfeitas são mais uma aspiração conceitual, do tipo ideal weberiano, que existe na mente daqueles que as estudam, observam e/ou qualificam" (Freidenberg, 2015, p. 2).

Sob a ótica das relações internacionais, as eleições deixaram de ser um tema de interesse puramente doméstico para ser algo importante também para a comunidade internacional (Norris, 2013a; Kelley, 2012a; Hyde, 2011).

Conforme indicado anteriormente, a importância da comunidade internacional nas eleições ocorreu, mormente, em função de mudanças nas 
demandas por parte de financiadores internacionais para com países receptores de incentivos econômicos, no que se refere aos condicionantes da ajuda externa (Hyde, 2011; Kelley, 2012) ${ }^{6}$. Os atores internacionais, através do ativo reforço do respeito a normas democráticas internacionais, passaram a ter o potencial de transformar o jogo doméstico, mudando o contexto institucional e deslocando o balanço de poder entre governo e oposição (Donno, 2013a, p.22).

Uma das formas atuais de aferir se parâmetros universais democráticos de boa governança eleitora foram seguidos, ao longo de um processo eleitoral, é através das Missões de Observação Eleitoral Internacional (MOEI), cujo papel é reconhecidamente importante dentre os demais atores da política internacional (Carothers, 1997).

Os espaços e redes por meio dos quais os observadores realizam suas avaliações é muito variado, tendo, como expoentes desde a Organização dos Estados Americanos e a Organização das Nações Unidas, até associações nãogovernamentais ou intergovernamentais regionais, a exemplo da União Europeia e do Centro Carter. Sendo que, nos últimos anos, a tarefa de observação tem contribuído para pressionar sobre mudanças nos processos eleitorais vigentes, além de fazer recomendações de boas práticas que sejam incorporadas em eleições futuras (Hyde, 2008). No entanto, ainda não há uma definição consensual sobre boas eleições. Alguns autores têm se debruçado sobre a tarefa de identificar quais os atributos que devem estar presentes para que uma eleição seja considerada válida (Freidenberg, 2015). Entre os principais atributos estão: (1) eleições livres e justas; (2) qualidade das eleições; (3) integridade eleitoral e; (4) ausência de más práticas, a serem discutidas em seguida.

\subsubsection{Eleições livres e justas}

Geisler (1993) trata a observação internacional eleitoral como "a melhor arte imperfeita", uma vez que "a falta de normas e diretrizes internacionais aceitas sobre o que realmente constitui uma eleição livre e justa contribuem

\footnotetext{
6 Dentre os incentivos internacionais podem ser citados também: investimentos externos; acordos de comércio preferenciais; filiação a alguma organização internacional; apoio militar; aumento no fluxo econômico; legitimidade e prestígio (Hyde, 2011).
} 
enormemente para as suas imperfeições" (p. 618), inclusive conflitos no âmbito da observação internacional.

De forma geral, eleições cumprem com sua condição de serem "livres" quando: não existem restrições normativas à competição; os candidatos são capazes de fazer campanha para angariar votos e os votantes não possuem seu direito de voto restrito por qualquer incidente. Assim, o que se propõe é que haja ampla liberdade de expressão, movimentação e associação no interior da vida política. Para as eleições serem "justas", o organismo eleitoral nacional deve ser neutro, competente e combater as possíveis fraudes que possam vir a surgir desde o momento das eleições até a contagem dos votos; todos os candidatos devem possuir acesso equitativo aos meios e recursos públicos de campanha; 0 segredo de voto deve ser respeitado (Goodwin-Gill, 2006; Diamond, 2004; OEA, 2003) $)^{7}$.

É difícil determinar um "ponto de corte", ou seja, um limite entre aquilo que é admissível do que não o é, nos processos eleitorais democráticos. Schedler (2002), contudo, afirma que o ponto de corte entre uma democracia eleitoral e um autoritarismo eleitoral seria o respeito pelos requisitos mínimos de liberdade e justiça que existe no primeiro caso. Para Freidenberg (2015, p. 6), "o que se exige como livre e justo é exatamente aquilo que dá conteúdo à democracia".

A maioria das críticas se encontra no campo da identificação do que seriam eleições livres e justas, uma vez que o termo poderia ser manipulado para atender pressões pela democratização. Dizem Hartlyn, McCoy e Mustillo (2008, p. 77):

\begin{abstract}
"Uma perspectiva focada na qualidade, por outro lado, gira em torno de julgamentos e avaliações por observadores eleitorais informados com base em um conjunto de normas. Observadores independentes baseiam suas decisões em informações fornecidas pelos partidos políticos e outros atores relevantes. Embora observadores independentes também possam ter razões para distorcer seus julgamentos públicos, enviesando-os, ou mudando-os com base em interesses escusos, o emprego de uma variedade de fontes deve ser capaz de minimizar o potencial risco sistemático de viés, evitando a armadilha óbvia de se basear exclusivamente nos julgamentos de atores dos partidos políticos".
\end{abstract}

\footnotetext{
7 Há uma série de condições mínimas que caracterizam eleições livres e justas, tais como o direito à participação, liberdade de expressão, associação e informação, além do direito ao escrutínio secreto, entre outras. No entanto, é difícil determinar um "ponto de corte", ou seja, um limite entre aquilo que é admissível do que não o é. "A avaliação desses processos é, em última instância conforme o critério de cada observador em dado país" (Geisler, 1993, p. 618).
} 
Para além disso, organizações internacionais têm buscado esclarecer o conceito. A União Inter parlamentária (IPU, na sigla em inglês), organização internacional de diálogo entre parlamentos ${ }^{8}$, determina que para uma eleição ser considerada livre e justa ela deve incluir: (1) direito de voto e participação; (2) direito de candidatura, partido e campanha e (3) direitos e responsabilidades do Estado $^{9}$. O primeiro direito diz respeito ao valor universal de direito ao voto secreto e direito de expressão quando direitos individuais são respeitados. Em seguida tem-se a questão da participação, da qual todos os cidadãos têm direito, podendo assim expressar suas opiniões políticas, fazer campanha, ter igual acesso ao conteúdo publicado nos meios de comunicação etc. Já o último trata das responsabilidades dos estados em promover um ambiente imparcial e nãodiscriminatório de registro dos eleitores, provendo informação sobre os procedimentos relativos ao processo eleitoral e assegurando a existência de um organismo eleitoral isento de partidarismo (IPU, 1994).

Da mesma forma, a adoção da Carta Democrática Interamericana, em 2001, pelos países membros da OEA, prevê o respeito aos direitos fundamentais como uma garantia de eleições livres e justas. O documento afirma que as eleições devem "estar baseadas no sufrágio secreto e universal" (p. 104), além de que devem respeitados os direitos humanos, separação e independência de poderes públicos; haver transparência das atividades governamentais; haver responsabilidade do governo para com a gestão pública; entre outras.

A União Europeia, que já realizou uma série de observações por toda a América Latina, também associa a ideia de eleições livres e justas aos direitos humanos. É aceito o fato de que eleições não equivalem à democracia, mas elas são consideradas um passo fundamental rumo à democratização e são abarcadas pelo vasto espectro dos direitos humanos, uma vez que "o direito à livre participação na escolha dos governantes está assegurado na Declaração

\footnotetext{
${ }^{8}$ A Organização trabalha em conjunto com as Nações Unidas, sobretudo junto ao Departamento de Assuntos Políticos (UNDPA, na sigla em inglês) e também com organizações interparlamentares, intergovernamentais e não governamentais movidas pelos mesmos ideais.

${ }^{9}$ Tal definição aparece na Declaração de Critérios para Eleições Livres e Justas, documento que foi adotado de forma unânime por todos os membros da IPU na 154a Sessão do Conselho Interparlamentar, em Paris, na data de 26 de março de 1994. A Organização das Nações Unidas passou a adotar os critérios estabelecidos na Declaração em sua prática na Divisão de Assistência Eleitoral (EAD), no Departamento de Assuntos Políticos (DPA) e no âmbito do Pnud, além de outras organizações regionais também as terem adotado, como a OSCE, o Conselho da Europa e a União Africana.
} 
Universal dos Direitos Humanos (artigo 21) e no Pacto Internacional sobre Direitos Civis e Políticos (artigo 25) (Carta Democrática Interamericana, p. 4) ${ }^{10}$ $"$

No entanto, a UE já reconheceu a ambiguidade do termo eleições livres e justas, realizando sua observação com base em critérios que determinam se uma eleição atendeu ou não a parâmetros internacionais democráticos de boa governança eleitoral, quais seriam: independência do órgão administrativo eleitoral de interesses partidários; transparência na divulgação de resultados do processo eleitoral; garantia de um registro de eleitores legítimo; inexistência de violência eleitoral, entre outras. Outras organizações internacionais de observação, tem adotado o mesmo procedimento, a exemplo da OEA, que em seus relatórios finais declara se uma eleição respeitou ou não a vontade popular.

Elklit e Svensson (1997) propõem um checklist de aproximadamente quarenta aspectos a serem considerados ao longo de um processo eleitoral que determinam se uma eleição foi livre e justa ou não. As categorias a serem avaliadas antes, durante e depois de uma eleição tratam do respeito às liberdades individuais básicas, passando pela resolução de conflitos entre o partido no poder e seus opositores, até o cumprimento de parâmetros relativos à publicação de resultados finais, entre outras questões (Cf. Quadro 1).

\section{Quadro 1 - Lista de verificação das duas principais dimensões de avaliação das eleições com as três fases de observação (antes, durante e após o dia da eleição)}

\begin{tabular}{|c|c|c|}
\hline \multirow{2}{*}{$\begin{array}{l}\text { Período de } \\
\text { tempo }\end{array}$} & \multicolumn{2}{|c|}{ Dimensão } \\
\hline & "Livre" & "Justa" \\
\hline
\end{tabular}

\footnotetext{
${ }^{10}$ Ambos os documentos citam o direito às eleições como fundamentais.
} 


\begin{tabular}{|c|c|c|}
\hline $\begin{array}{l}\text { Antes do } \\
\text { dia das } \\
\text { eleições }\end{array}$ & $\begin{array}{l}\text { Liberdade de movimento } \\
\text { Liberdade de expressão (para } \\
\text { candidatos, meios de comunicação, } \\
\text { eleitores e outros); } \\
\text { Liberdade de reunião; } \\
\text { Liberdade de associação; } \\
\text { Liberdade do medo ligado à eleição } \\
\text { e campanha eleitoral; } \\
\text { Sufrágio igualitário e universal; } \\
\text { Ausência de impedimentos à } \\
\text { eleição; }\end{array}$ & $\begin{array}{l}\text { Processo eleitoral transparente; } \\
\text { Ato eleitoral e sistema eleitoral que garantam } \\
\text { não haver qualquer tipo de privilégios a grupos } \\
\text { políticos ou sociais; } \\
\text { Ausência de impedimentos para inclusão no } \\
\text { registro de eleitores; } \\
\text { Estabelecimento de uma comissão eleitoral } \\
\text { independente e imparcial; } \\
\text { Tratamento imparcial de candidatos pela polícia, } \\
\text { Forças Armadas e tribunais de justiça; } \\
\text { Oportunidades iguais de participação para } \\
\text { partidos políticos e candidatos independentes; } \\
\text { Programas de educação imparciais aos } \\
\text { eleitores; } \\
\text { Uma campanha eleitoral sem tumulto (conforme } \\
\text { código de conduta); } \\
\text { lgual acesso dos candidatos aos meios de } \\
\text { comunicação estatais; } \\
\text { Distribuição imparcial de fundos públicos para } \\
\text { partidos políticos (se for o caso); } \\
\text { Ausência de mau uso das instalações } \\
\text { governamentais para propósitos políticos; }\end{array}$ \\
\hline $\begin{array}{l}\text { No dia da } \\
\text { eleição }\end{array}$ & $\begin{array}{l}\text { Oportunidade de participar } \\
\text { eleição; }\end{array}$ & $\begin{array}{l}\text { Acesso a todos os centros de votação de } \\
\text { representantes de partidos políticos, } \\
\text { observadores internacionais e nacionais } \\
\text { credenciados e meios de comunicação; } \\
\text { Segredo do voto; } \\
\text { Inexistência de intimidação de votantes; } \\
\text { Adequado desenho dos papeis de voto; } \\
\text { Urnas de votação adequadas; } \\
\text { Assistência imparcial aos eleitores (se } \\
\text { necessário); } \\
\text { Procedimento correto de contagem de votos; } \\
\text { Tratamento correto dos boletins de voto nulos; } \\
\text { Medidas corretas de precaução no transporte de } \\
\text { material sensível; } \\
\text { Proteção imparcial dos centros de votação; }\end{array}$ \\
\hline
\end{tabular}

Anúncios oficiais e rápidos dos resultados da eleição;

\begin{tabular}{|c|c|c|c|c|}
\hline $\begin{array}{c}\text { Depois do } \\
\text { dia da } \\
\text { eleição }\end{array}$ & $\begin{array}{l}\text { Possibilidades } \\
\text { contestação; }\end{array}$ & legais & de & $\begin{array}{l}\text { Tratamento imparcial de qualquer reclamação } \\
\text { quanto às eleições; } \\
\text { Relatórios imparciais dos resultados eleitorais } \\
\text { pelos meios de comunicação; } \\
\text { Aceite dos resultados por todos os envolvidos. }\end{array}$ \\
\hline
\end{tabular}

Adaptado de: Elklit e Svensson, 1997, p. 36.

Assim, ao se considerar uma eleição, o que os observadores avaliam é uma série de pré-requisitos previstos no próprio código eleitoral do país e, em menor medida, em documentos normativos internacionais.

Freidenberg (2015, p. 2) qualifica as eleições perfeitas mais como "uma aspiração conceitual, do tipo ideal weberiano, que está na mente daqueles que as estudam, observam e/ou qualificam". Segundo Mozaffar e Schedler (2002), 
em democracias já estabelecidas, eleições tendem a ser vistas como fraudulentas não porque possuem deficiências, erros ou por falta de precisão ${ }^{11}$. Elas são consideradas ruins quando problemas não comuns, ou seja, aleatórios que surgem pela dificuldade na administração do processo eleitoral, criam um espaço que não é propício a que haja competição eleitoral, afetando de forma sistemática seu resultado final e evidenciando falhas. Para Hyde (2008), um dos principais desafios a serem enfrentados pelos observadores é, portanto, identificar entre aquilo que poderia ser considerado uma falha ou erro da administração (má prática) daquilo que se constituiria como uma fraude de fato (manipulação).

É a garantia de credibilidade e legitimidade derivadas de uma boa governança eleitoral que auxiliará a diminuição das tensões, dirimindo as contestações que possam vir a surgir com o propósito de questionar o pleito ou mesmo anular todo o processo.

Em geral, o que é esperado por jornalistas, policymakers, políticos e outros atores importantes das relações internacionais com relação aos observadores é que estes forneçam a resposta para a pergunta sobre se uma eleição foi livre e justa. No entanto, de forma quase paradoxa, "quanto mais experiente for uma organização de observação, mais hesitante será sua resposta" (ibidem, p. 24; Geisler, 1993). E isto decorre do fato de que, não há um único e claro parâmetro de eleições livres e justas, sendo mais aceita a ideia de melhores práticas.

Conforme Elklit e Svensson (1997, p. 42), “a frase 'livre e justa' não pode aparecer associada a apenas um padrão fixo e universal de competição eleitoral, visto que tal padrão não existe e que a complexidade de um processo eleitoral faz com que qualquer noção simplista seja irreal", ${ }^{12}{ }^{13}$, da mesma forma, Elklit e Reynolds (2005), afirmam que mesmo a experiência comparada não pode ainda esclarecer o significado da expressão, visto que não existe um consenso que

\footnotetext{
${ }^{11}$ De acordo com Elklit e Reynolds (2005) são tolerados alguns tipos de erros, dado que em eventos rotineiros como o são as eleições democráticas, não é possível controlar todos os eventos inesperados que surgem em meio ao processo eleitoral.

${ }^{12}$ A adequação do termo a todo processo eleitoral poderia incorrer no que Giovanni Sartori (1970) denominou como "estiramento conceitual", situação que ocorre quando pesquisadores tendem a estender seus modelos e hipóteses de forma a englobar novos casos, adaptando suas categorias analíticas para que estas caibam nos novos contextos em análise.

${ }^{13} \mathrm{O}$ mesmo pensamento é compartilhado por Goodwin-Gill (2006).
} 
qualifique todos os processos eleitorais a partir de uma base comum, com conceitos que possam viajar entre diferentes contextos e, que, possam gerar padrões sistemáticos sobre o que constituiriam boas práticas na América Latina.

A seguir são apresentados enfoques mais abrangentes, que tentam dar conta não somente de avaliar as duas dimensões - livres e justas -, mas antes, veem todo o processo, sendo cada uma de suas partes, importantes indicadores.

\subsubsection{Qualidade das eleições}

Para Elklit \& Reynolds (2005) há uma tendência por parte dos observadores eleitorais em ver a qualidade das eleições de uma forma bimodal, ou seja, ela é boa ou ruim, ou quando há necessidade de maior precaução, ela é vista como "substancialmente livre e justa" (p. 149).

Ao tentar uma interpretação menos dicotômica, Bjornlund (2001) argumenta que todas as eleições devem ser avaliadas da mesma forma, a partir de padrões internacionalmente reconhecidos. Ou seja, para além de um processo livre e justo, devem existir oportunidades para que todos os partidos políticos possuam iguais chances de competir, moderado acesso aos meios de comunicação em geral, administração eleitoral imparcial, não existência de qualquer tipo de intimidação política ou policial e capacidade por parte do organismo responsável pela realização das eleições de processar queixas e/ou denúncias (idem).

Muitas vezes tais pré-requisitos não são garantidos de forma absoluta pelo Estado, em outras palavras, ele não consegue garantir sozinho que todos os pré-requisitos listados sejam cumpridos. É aí que ocorre a prática dos observadores eleitorais internacionais, no entanto, sua atuação não é totalmente livre, uma vez que possui limitações, em geral por parte dos próprios governos que fazem o convite à observação ${ }^{14}$.

\footnotetext{
14 Nas eleições de 2015 da Indonésia, por exemplo, a União Africana (UA), foi a única organização internacional convidada a participar do pleito, tendo os grupos da sociedade civil e outras mídias paraestatais sido fortemente reprimidas. Da mesma forma, há casos de fechamento de escritórios regionais, como no Azerbaijão em 2013, quando a Organização para a Segurança e Cooperação na Europa (OSCE), fechou seu escritório no país ou mesmo na Venezuela em 2015, após a saída do Centro Carter (CC), ambas situações motivadas por dificuldade na realização da prática de monitoramento.
} 
É comum ver diferentes avaliações por parte de missões de observação diferentes, sobre um mesmo processo eleitoral, uma vez que há uma série de fatores que podem influenciar na forma como uma eleição será avaliada.

Segundo Carothers (1997), a observação internacional de eleições tem contribuído grandemente para a disseminação de padrões básicos relativos à administração eleitoral. Ao mesmo tempo tal prática fez avançar a ideia de que a manutenção de eleições regulares genuínas é uma norma internacional, de acordo com documentos universais, a exemplo da Declaração Universal dos Direitos Humanos e outros instrumentos básicos internacionais de direitos humanos (Ver Quadro 2).

\section{Quadro 2 - Instrumentos de Direitos Humanos Internacionais em referência a eleições democráticas}

Ano Tipo de instrumento

1948 Declaração Universal dos Direitos Humanos

1948 Declaração Americana dos Direitos e Deveres do Homem

1950 Convenção Europeia para a Proteção dos Direitos do Homem e das Liberdades Fundamentais

1952 Convenção sobre os Direitos Políticos das Mulheres

1966 Pacto Internacional sobre Direitos Civis e Políticos

1966 Convenção Internacional sobre a Eliminação de Todas as Formas de Discriminação

1968 Protocolo (No. 4) da Convenção Europeia para a Proteção dos Direitos do Homem e das Liberdades Fundamentais

1969 Convenção Americana sobre Direitos Humanos

1969 Comentário Geral 25 do Comitê de Direitos Humanos das Nações Unidas sobre o artigo 25 do Pacto Internacional sobre os Direitos Civis e Políticos

1979 Convenção sobre a Eliminação de Todas as Formas de Discriminação contra as Mulheres

1981 Carta Africana dos Direitos Humanos e dos Povos

1985 Carta Europeia da Autonomia local

1990 Documento do Encontro de Copenhagen de 1990, da Conferência sobre a Dimensão Humana (Documento de Copenhagen, 1990)

1991 Tratado de Assunção

1994 Protocolo (No. 1) da Convenção Europeia para a Proteção dos Direitos do Homem e das Liberdades Fundamentais

1994 Declaração sobre Critérios para eleições livres e justas da União Interparlamentar

1998 Protocolo de Ushuaia

2001 Carta Democrática Interamericana

2001 Protocolo da Comunidade Econômica dos Estados da África Ocidental (ECOWAS) sobre Democracia e Boa Governança Complementar ao Protocolo relativo ao Mecanismo para a Prevenção de Conflitos, Gestão, Resolução, Manutenção da Paz e Segurança

2002 Convenção sobre os Padrões de Eleições Democráticas, Igualdade de Direitos e Liberdades dos Estados-Membros da Comunidade de Estados Independentes

2004 Princípios e Diretrizes Reguladoras de Eleições Democráticas da Comunidade Sul Africana de Desenvolvimento (SADC)

Fonte: Merloe (2008). 
Ao longo dos anos 1970 e 1980, o foco da defesa dos direitos humanos girava em torno da luta contra a inexistência de direitos em um determinado sistema político, mais especificamente, os regimes autoritários que violavam uma série de direitos básicos através da tortura ou assassinatos políticos. Mais recentemente ${ }^{15}$, com a Terceira Onda de democratização e o fim da Guerra Fria, "a ideia das eleições como um direito político, mais que uma mera opção política, ganhou terreno internacional" (idem, p. 21).

De fato, não somente as eleições se tornaram mais próximas aos direitos humanos, como a observação permitiu que uma série de ações executadas pelos observadores, fossem reconhecidas na arena internacional como "boas práticas" a serem seguidas pelos países, que desejavam se democratizar e que, dentro deste processo, utilizavam as eleições como um instrumento plausível desse processo ${ }^{16}$. Estão entre as "boas práticas": a visita dos observadores aos locais de votação; maior rigor na redação das listas de votantes; existência de observadores nacionais etc.

Freidenberg (2015) afirma que a qualidade das eleições tem como foco a avaliação a partir de "realizações" e não somente em princípios normativos (a exemplo da legitimidade de um processo eleitoral). A partir deste enfoque são incorporadas outras dimensões à observação eleitoral como "a transparência, administração das eleições e o exercício dos direitos da cidadania" (idem, p. 7).

A qualidade do processo eleitoral é um indicador importante porque permite distinguir entre uma democracia eleitoral e uma autocracia eleitoral (Hartlyn, McCoy e Mustillo, 2008; Schedler, 2002). Uma eleição para ser considerada democrática, necessita ser processualmente justa e tecnicamente sólida, o que significaria a minimização de eventuais irregularidades que pudessem afetar o andamento do processo. Assim, ao final, todo o processo

${ }^{15}$ Cf. Hyde e O'Mahony (2010), Carothers (1997) e Elklit e Svensson (1997): a observação ampliou-se conforme cresceu o número de países que se democratizavam.

16 Muitos padrões de observação foram desenvolvidos a partir de diretrizes ditadas por organizações intergovernamentais que têm atuado na área, a exemplo da Organização para a Segurança e Cooperação na Europa (OSCE), através da publicação do Manual de Observação Eleitoral - já na sua 6 ${ }^{\underline{a}}$ edição em 2010; e mais recentemente, uma série de outras organizações intergovernamentais, a exemplo da União Africana (UA), Organização dos Estados Americanos (OEA), Instituto Republicano Internacional (IRI), publicaram a Declaração de Princípios para a Observação Internacional de Eleições e o Código de Conduta para Observadores Internacionais de Eleições, a partir de uma reunião durante Assembleia da ONU, em Nova York, na data de 27 de outubro de 2005. 
eleitoral angariaria a confiança dos votantes no sistema eleitoral, devido sua integridade, seriedade e eficiência (Hartlyn, McCoy e Mustillo, 2008). No caso latino-americano, contudo, nos últimos anos a reeleição tem sido um fator que contribuiu para tornar um processo eleitoral inaceitável. Na maioria dos casos, o problema mais significativo é o boicote por parte da oposição, através do estímulo à violência ou outros meios, levando a que o ciclo eleitoral deixe de apresentar as garantias necessários para que seja considerado válido (idem).

Para Alvarez e Hall (2008), uma eleição democrática deve ser: (1) transparente; (2) segura; (3) realizada de forma profissional; (4) prover resultados precisos; (5) manter em segredo o voto dos cidadãos; (6) prover resultados em tempo; (7) ter total responsabilidade e accountability ao longo de todo o processo e (8) proporcionar um ambiente equitativo para todos os participantes da eleição.

Ainda que exista divergências sobre o que de fato deve ser avaliado ${ }^{17}$, as missões de observação eleitoral internacionais seguem as orientações das Nações Unidas. Em 27 de outubro de 2005, mais de vinte organismos internacionais assinaram a Declaração de Princípios para a Observação Internacional Eleitoral (DPIOE), cujo objetivo era o de estabelecer padrões e normas comuns para as atividades de observação. Nesta Declaração está definido 0

\footnotetext{
“... interesse da comunidade internacional na realização de eleições democráticas, parte do desenvolvimento democrático, aí incluídos o respeito pelos direitos humanos e Estado de Direito. A observação eleitoral internacional, que incide sobre os direitos civis e políticos, é parte do monitoramento internacional dos direitos humanos e deve ser realizada com base nos mais altos padrões de imparcialidade com relação aos concorrentes políticos nacionais, devendo estar livre de quaisquer considerações bilaterais ou multilaterais que poderiam entrar em conflito com sua imparcialidade. Ela avalia os processos eleitorais em conformidade com os princípios internacionais para uma verdadeira eleição democrática e de direito doméstica, enquanto reconhece que é o povo de um país que, em última instância, determina a credibilidade e legitimidade de um processo eleitoral" (DPIEO, 2005, p. 1).
}

Embora Elklit e Svensson (1997) afirmem que há diferenças na constituição política e na forma como as eleições são realizadas em cada país, eles consideram que a tarefa principal dos observadores é "acompanhar os vários componentes do processo eleitoral comparando-os com a lei eleitoral

\footnotetext{
17 Cf. Kelley, 2012a.
} 
nacional" (p. 37). Assim, se algumas regras forem quebradas uma eleição não pode ser considerada aceitável, ou mesmo livre e justa, sendo bastante fina a linha que separa um processo legítimo de outro ilegítimo. Segundo os autores, a avaliação se um processo eleitoral foi de fato democrático tende a ser realizado mediante o estudo de suas várias etapas e, então, identificando quais critérios promovem a liberdade e a justiça democráticas. Esta é a perspectiva que mais se aproxima da interpretação de Dahl (2005), uma vez que para este autor uma série de critérios devem ser respeitados antes mesmo de uma eleição ser considerada livre e justa.

A partir daí o próprio processo eleitoral deve ser dividido em suas fases componentes, respectivamente, pré, durante e após as eleições, sendo que a cada um correspondem determinados critérios de avaliação.

Além dos observadores realizarem um trabalho baseado na observação de determinados critérios pré-estabelecidos, identificando possíveis irregularidades, eles também, avaliam as eleições conforme a expectativa da sua seriedade: se há alguma tendência a privilegiar um candidato ou outro e quão significantes ${ }^{18}$ foram os resultados finais (Elklit e Svensson, 1997).

A perspectiva da qualidade das eleições, no entanto, tende, conforme já indicado, manter uma visão bimodal, encaixando as eleições em suas formas boas ou ruins. A dimensão das eleições apresentada a seguir, trabalha com parâmetros internacionais de avaliação, sendo, portanto, mais abrangente e não dicotômica.

\subsubsection{Integridade eleitoral}

Em geral, os observadores ecoando a linguagem dos documentos internacionais - a exemplo da Declaração Universal dos Direitos Humanos, de 1948 - frequentemente divulgam o resultado de uma eleição como algo que de fato "refletiu a vontade da população" ou, de forma mais simplista, como "livre e justa". Ao contrário, quando o processo tem muitos problemas e se encontra fora dos padrões internacionais, é comum observar nos relatórios finais a descrição

\footnotetext{
${ }^{18}$ Significante é usado aqui como sinônimo de significância estatística, ou seja, um resultado que foi improvável de ter ocorrido por acaso, tendo-se assim, confiança no resultado obtido. Para as eleições, o resultado deve representar a vontade popular.
} 
destes como "fraudulentos", marcado por "más práticas" ou mesmo como tendo incorrido em violações contra os princípios democráticos de direitos humanos (Norris, 2013a; Kelley, 2012a; Hyde, 2011).

A linguagem muitas vezes serve como um instrumento diplomático, mais que um esclarecimento sobre aquilo que de fato foi observado ao longo de um processo eleitoral (Elklit e Svensson, 1997; Elklit e Reynolds, 2005). E muitas das missões utilizam esse tipo de linguagem.

Muitos documentos internacionais citam quais elementos devem existir para as eleições sejam consideradas democráticas. O Pacto Internacional sobre Direitos Civis e Políticos, em seu artigo 25, especifica a necessidade de: eleições periódicas a intervalos regulares; sufrágio universal que inclua todos os setores da sociedade; sufrágio igualitário; o direito de constestação; o direito de votar; o segredo de voto; eleições legítimas e eleições como reflexo da vontade das populações.

De uma forma sucinta, a integridade eleitoral é entendida como os "princípios internacionais acordados, valores, e padrões eleitorais, aplicados internacionalmente a todos os países durante o ciclo eleitoral, incluindo o período pré-eleitoral, campanhas, dia de votação e além" (Norris, 2013b, p. 579). Esta abordagem surge como uma resposta às críticas dos enfoques das eleições livres e justas e da qualidade das eleições.

Essa terceira geração de estudos defende que a eleição deve ser avaliada como um ciclo, podendo aí ser incluídos ainda, o modo como os atores políticos e cidadãos aceitam ou não os resultados finais (idem).

De uma forma mais ampla, a integridade eleitoral pode ser definida tendo os seguintes elementos: (1) eleições legítimas, que incorporam valores e normas globais com base em acordos multilaterais, convênios internacionais, tratados e leis internacionais; (2) existência de práticas que variam em relevância conforme sua gravidade e consequências e; (3) noção de um ciclo eleitoral (não se limitando somente ao dia da eleição e seus resultados, mas abrangendo ainda períodos anteriores) (ibidem; ACE Project, s.d.) ${ }^{19}$.

\footnotetext{
19 O DPIEO segue a visão da integridade eleitoral. O documento alia a visão integral do processo à questão da qualidade das eleições, incluindo dimensões como profissionalização da gestão eleitoral e cultura política.
} 


\section{Figura 1 - 0 ciclo eleitoral}

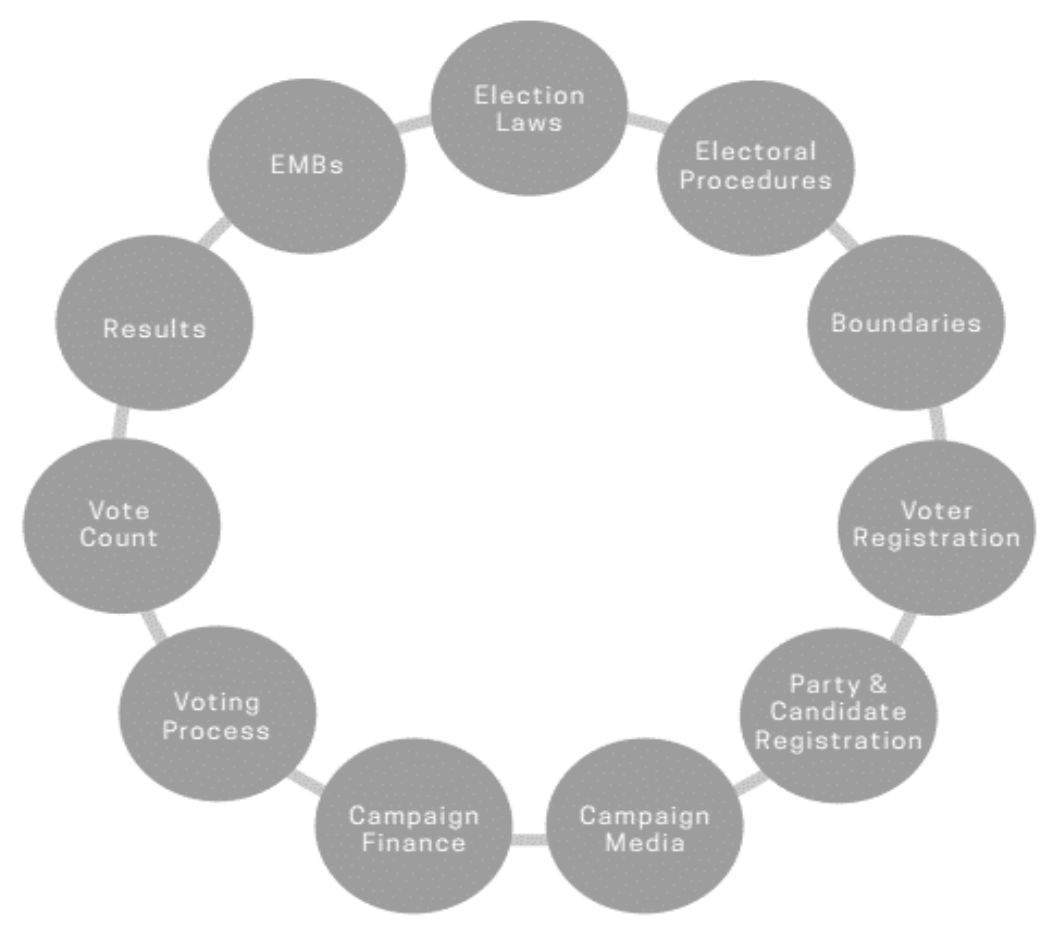

Fonte: Norris et al, 2015, p. 14.

*EMBs: Organismos de Administração Eleitoral.

Estes autores veem as eleições de um ponto de vista mais organizacional, em que para cada parte do ciclo eleitoral determinadas regras de administração devem ser seguidas. Para eles ainda, o respeito às regras não garante a não ocorrência de fraudes, mas acreditam que serão minimizadas as chances de que a fraude aconteça, uma vez que identificadas as causas, mas as chances de que a fraude aconteça, serão minimizadas. Isso porque, identificadas as causas, poderão determinar onde a fraude ocorreu, em qual parte do processo (idem). Norris, Franck e I Coma (2013) advertem, contudo, que até mesmo em países nos quais as eleições são aceitáveis tanto nacional quanto internacionalmente, a qualidade da competição varia de forma significativa. Nos Estados Unidos, por exemplo, país considerado exemplos de boa governança eleitoral democrática, os autores, argumentam que nas eleições presidenciais de 2012 foram levantadas dúvidas sobre a forma como o processo eleitoral foi realizado. Levando a que a Casa Branca, criasse uma Comissão Especial de Administração Eleitoral. 
É possível medir, então, até que ponto as eleições cumpriram com um mínimo de critérios para que sejam aceitas como limpas e justas, conforme normas internacionais, mas também de acordo a avaliação, de outros atores, como os observadores internacionais ${ }^{20}$.

Schedler (2002, p. 36) vê a importância das eleições ao mesmo tempo como um "conto de manipulações autoritárias e uma saga de vitórias democráticas". Chama a atenção para o fato de que as eleições têm sido usadas historicamente como instrumento para a manutenção de regimes autoritários e também como um artificio de governança democrática. Por isso, a importância de se observar todo o ciclo eleitoral democrático, para que nenhum elo se quebre ao longo da cadeia, dando margem a críticas ou mesmo minando sua legitimidade.

Além disso, o autor argumenta que o debate que se tem atualmente sobre a caracterização dos diferentes tipos de democracias liberais se deve à condição necessária, porém não suficiente, que são as eleições.

Se caso uma das normas mínimas for quebrada, isso implicaria em consequências para as demais normas do ciclo, levando a sua anulação. A lógica aqui é que o país não se torna menos democrático, ele se torna não democrático. Assim, Schedler (2002) vê um "menu de manipulação" que ameaça as democracias eleitorais, ou seja, qualquer má prática no ciclo eleitoral poderia comprometer toda a cadeia eleitoral, dirimindo sua legitimidade. Norris (2013b, p. 567) defende a necessidade da integridade eleitoral, pois esta "contém múltiplas dimensões, e cada uma delas necessita de monitoramento" para que ao final a avaliação seja mais completa e abrangente.

Nesse sentido, as missões de observação têm papel fundamental, não somente ao prezar pela clareza e rapidez na divulgação dos resultados finais, mas também monitorando onde e quando ocorreu uma ruptura que poderia minar todo o processo eleitoral, ou, em outras palavras, zelando pela qualidade do processo (idem).

Tal abordagem é observada, por exemplo, na atuação do Instituto Nacional Democrático (NDI, na sigla em inglês). A organização, tem como meta

\footnotetext{
${ }^{20}$ Além da observação, a avaliação das eleições do ponto de vista de sua qualidade, tem ainda como fontes: meios de comunicação; indicadores de democracias (Freedom House, Polity IV etc), experimentos de campo e análises pós-eleitorais.
} 
"a promoção da integridade eleitoral e dos processos políticos com base em normas internacionais e nos aspectos práticos que mobilizam a participação política dos cidadãos" (Merloe, 2008, p. 3).

Entre as normas internacionais prescritas para as eleições estão aquelas de direitos humanos contidas em documentos como a Declaração Universal dos Direitos Humanos, de 1948, que são a base para a inclusão, transparência, accountability e confiança pública nas eleições. Segundo Norris (2013b, p. 577), "em integridade eleitoral as normas podem ser compreendidas como os padrões apropriados de condução das eleições". ${ }^{21}$ Como consequência,

\begin{abstract}
"... onde as eleições são vistas como não justas, corruptas, ou falhas, há o fortalecimento da percepção pública de que ocorreram más práticas, diluindo o sentimento de legitimidade política, diminuindo 0 número de eleitores e encorajando os protestos políticos. Ao contrário, quando as eleições cumprem normas internacionais de integridade eleitoral, os pleitos são aceitos de forma ampla como legítimos pelos eleitores, encorajando o ativismo cívico e reduzindo o número de protestos políticos. " (idem, p. 571)
\end{abstract}

No entanto não há consenso sobre quais normas realmente devem ser seguidas em cada caso, para garantia da integridade eleitora ${ }^{22}$. De acordo com Norris (2013a), a percepção da população russa sobre uma série de eleições da Duma e presidenciais foi significativamente diferente daquelas dos observadores internacionais. Embora os observadores estrangeiros tenham apontado deficiências ao longo dos processos, para os cidadãos ela foi considerada justa e honesta.

Mesmo em democracias consolidadas, onde a boa governança eleitoral é dada como garantida, podem surgir denúncias de que a integridade eleitoral foi ameaçada por irregularidades. Na Grã-Bretanha, em 2001, o clima de desconfiança sobre a manipulação no cadastro de eleitores e fraude na contagem dos votos permeou todo o processo de escolha de novos representantes gerais (Norris, 2013b; Hartlyn, McCoy e Mustillo, 2008).

\footnotetext{
${ }^{21}$ Mesmo em democracias consolidadas, onde a governança eleitoral é dada como garantida, podem surgir denúncias de que a integridade eleitoral foi ameaçada por irregularidades. Na GrãBretanha, em 2001, o clima de desconfiança sobre manipulação no cadastro de eleitores e fraude na contagem dos votos, permeou todo o processo de escolha de novos representantes gerais (Norris, 2013b; Hartlyn, McCoy e Mustillo, 2008).

22 Interessante notar que a preocupação em conceituar e medir a integridade eleitoral apareceu juntamente à expansão de regimes híbridos, autoritarismos eleitorais e novas vias de democratização, em especial, aquelas cuja característica principal são as eleições (Levitsky e Way, 2010).
} 
Da mesma forma, governos de autocracias eleitorais (Schedler, 2002) ou pseudo-democracias (Hyde, 2011) podem pretender realizar um processo eleitoral conforme determinadas normas internacionais, ao mesmo tempo em que mantém estruturas políticas para manutenção de seus poderes. Essa é a visão, por exemplo, de neorrealistas como Mearsheimer (1995). Para o autor, a brecha entre princípio e prática aparece sem surpresa, alinhando-se de forma fácil com a visão de que os Estados são movidos por interesses próprios, sendo as normas, apenas uma vitrine expositiva ao mundo ${ }^{23}$.

Dentro desta visão, o mundo é visto como extremamente competitivo, em que os Estados lutam por mais poder. As instituições só teriam capacidade marginal de atuação, porque promoveriam seus objetivos através da manipulação do comportamento dos Estados. Nesse cenário, os Estados buscarão tirar vantagens para si.

A abordagem neorrealista argumenta que as instituições internacionais são e sempre serão fundamentalmente ineficazes, uma vez que elas não podem impedir os Estados de se engajar na política de poder em busca de seus próprios interesses. Assim, as instituições só possuem poder marginal e o Estados, em competição, se tornam apenas reflexo da distribuição de poder no sistema internacional. Até mesmo a cooperação, no cumprimento de normas, é utilizada como um pretexto para que um Estado possa ter vantagens sobre o outro (idem)

Para Mearsheimer (2012), os estadistas aceitam as normas liberais e, invariavelmente, enfatizam seu compromisso com o estado de direito. No entanto, muitas vezes, o interesse nacional obriga-os a agir de modo que contradiz tais regras. Quando as normas liberais ou do direito internacional são violadas, os dirigentes costumam inventar histórias para mascarar o que fazem.

Por outro lado, construtivistas argumentam que as normas são um elemento fundamental na política internacional, sendo as diferenças em sua aplicação explicadas pelas interações e processos de socialização dos agentes (Risse et al, 1999). O foco passaria então não para as melhorias e sucessos das instituições internacionais, mas antes à contestação de conceitos estáticos do neorrealismo - e também, neoliberalismo -, com base no relacionamento entre agente e estrutura e, não mais, em abordagens materialistas e quantificáveis.

23 "Grandes poderes usam instituições para promover seus interesses" (Mearsheimer,1995, p. 86). 
Para os construtivistas, o papel das organizações internacionais seria o de defender seus valores e ideologias, cuidadosamente construídos, determinando seu comportamento (Wendt, 1992).

Um terceiro ponto de vista, afirma que mesmo não acreditando no poder e alcance das normas eleitorais democráticas, atores podem ter seu comportamento moldado por elas, em virtude de diferentes incentivos (norm enforcement). Devido, maiormente, à existência de condicionalidades que constrangem os líderes a adotar posturas das quais não são adeptos, que variam de imposições para recebimento da ajuda externa (Hyde, 2011, Kelley, 2012), ou mesmo do desejo de aderir a uma organização internacional, bloco econômico ou regime internacional até pressões de fontes nacionais, a exemplo de grupos de pressão e partidos da oposição (Donno, 2013).

Por sua vez, o monitoramento internacional contribui para diminuir a relutância dos Estados com relação a normas democráticas, através da publicização e exposição de informações. "A publicidade a partir de relatórios de monitores ajuda a pressionar os Estados relutantes a dar prioridade à defesa da norma sobre outros assuntos concorrentes, enquanto a informação os auxilia na tomada da melhor posição conjunta" (Donno, 2010, p. 594).

Segundo Hyde (2011), estados em busca de benefícios internacionais estão motivados a enviar sinais de legitimidade, mostrando que eles agem de acordo com normas internacionais, nomeadamente quando isso implica no aumento de sua quota de benefícios, a exemplo da ajuda externa, investimentos estrangeiros, turismo, comércio etc.

Pesquisa experimental de Donno (2010) apontou que relatos de má conduta durante as eleições divulgados pelas missões de observação influenciam no tipo de comportamento esperado. Sendo que, "sanções ou ameaças específicas para punir um governo, são muito mais prováveis de acontecer se os observadores denunciarem que houve má conduta eleitoral" (idem, p. 595) ${ }^{24}$.

\footnotetext{
24 Segundo Donno (2010), a má conduta eleitoral pode ser caracterizada como a violação de qualquer um dos princípios de eleições livres e justas, em especial, quando evidentes um dos seguintes padrões: restrição à participação de partidos ou eleitores; um ambiente de campanha tendencioso que favorece o partido no poder; além de falhas na contagem ou tabulação de resultados.
} 
Se for confirmada conduta intencional, caracterizada, por exemplo, pela alteração de número de votos para favorecimento de um determinado candidato na disputa, é mais provável que sejam aplicadas sanções, como suspensão de ajuda externa ou de participação em uma organização internacional (condicionalidade). Enquanto que, embora havendo má conduta, esta não tenha sido intencional, outros instrumentos podem vir a ser utilizados, como declarações oficiais, resoluções ou declarações críticas à má conduta eleitoral. As medidas têm como objetivo provocar uma mudança futura no comportamento dos governos, com relação aos processos eleitorais que conduzem (ibidem).

Com base na definição de norma internacional conforme Finnemore e Sikkink (1998, p. 890), como "um padrão compartilhado apropriado para atores com uma determinada identidade", Hyde (2011) argumenta que quando outros estados imitam os sinais emitidos em busca de benefícios internacionais e da manutenção de seu status como um ator que atende as normas democráticas, novos comportamentos se generalizam. Assim, "se um sinal é aceito por outros atores internacionais como um comportamento comum a todos os Estados que possuem uma conduta valorizada (aquela que promove a cooperação e o bemestar), então se torna uma nova norma internacional” (p. 892).

Assim, uma das novidades mais intrigantes nas relações internacionais nos últimos anos é o convite à observação internacional de eleições nacionais como uma norma internacional. Pode-se acrescentar ainda, que a maior aceitação de valores universais democráticos, identificados com direitos humanos (Norris, 2013b; Kelley, 2012), contribuiu para a expansão desta prática, uma vez que possíveis atuações contrárias a ela são consideradas pelas organizações internacionais violações graves, implicando na perda de benefícios externos.

Países ao redor do mundo enfrentam grandes desafios ao tentar atingir normas internacionais de integridade eleitoral. Mesmo democracias já estabelecidas podem ser afetadas por casos de violação da integridade eleitoral, que minam a credibilidade de todo o processo (Norris, 2013b). No entanto, a autora argumenta que são as más práticas as responsáveis por essas violações, que serão detalhadas no próximo tópico.

\subsubsection{Más práticas}


Mais recentemente, a literatura tem dado ênfase não somente à integridade eleitoral, mas às más práticas, de uma maneira específica. A partir deste enfoque é deixado de lado o binômio "com qualidade x sem qualidade", focando-se naquilo que constituem de fato as más práticas (Freidenberg, 2015).

Birch (2011, p. 14), identifica as más práticas como "a manipulação do processo eleitoral de forma privada ou pessoal, em substituição ao interesse público". Norris (2013b, p. 579), as define como "as violações da integridade eleitoral em qualquer estágio do longo ciclo sequencial de processos eleitorais, incluídos o período pré-eleitoral, campanhas políticas, dia de votação e seus desdobramentos". Assim, as más práticas intencionais, ou seja, a manipulação estratégica das eleições (Norris, 2013a; Beaulieu \& Hyde, 2009), se mostra como um dos principais desafios à democratização atualmente (Birch, 2011).

As más práticas também enfraquecem a qualidade da governança democrática, através da distorção da competição eleitoral; ceifando sentimentos de confiança e legitimidade; diminuindo a participação no número de eleitores e, nos casos mais extremos, incentivando a instabilidade do regime, violência e, até mesmo, guerra civil (idem).

Para Norris (2013b), as más práticas se tornaram inaceitáveis não somente aos olhos dos observadores internacionais, como também, aos eleitores, em geral, com base na defesa dos critérios de integridade eleitoral. Sendo que, entre as práticas mais comuns estão: mau uso dos recursos de um Estado para favorecer um candidato; viés na cobertura midiática das campanhas e do processo eleitoral; órgão eleitoral sem independência; limites à observação internacional; entre outros.

Birch (2011), através de uma análise transnacional sobre as diferentes dinâmicas de más práticas descobriu, que no caso latino-americano, a manipulação do arcabouço legal é o meio mais comum de má conduta na região. Deste ponto de vista, as más práticas podem ser interpretadas em termos das violações de normas eleitorais. De uma perspectiva mais sociológica, elas são vistas como as percepções do que se constitui uma violação das normas, podendo ser medidas através das pesquisas de opinião. Por fim, as más práticas podem ser contrapostas às boas práticas, que seriam aquelas práticas defendidas no cenário internacional pelas agências multilaterais e que são 
aplicadas pelos observadores, ao longo dos processos eleitorais. Em outras palavras, seriam as práticas que não se desviam dos modelos normativos de democracia.

Já Norris (2013a) levanta a questão da diferença entre a manipulação eleitoral e as fraudes eleitorais, uma vez que a distinção entre as duas é muito fina ${ }^{25}$. Para a autora, ambas afetam os princípios democráticos de formas diferentes. A fraude as violam diretamente, enquanto que as más práticas fazem com que elas erodam. Da mesma forma, a fraude eleitoral deixa pouco espaço para que os eleitores exerçam suas liberdades e direitos - que são a base fundacional das eleições democráticas e competitivas -, enquanto que as más práticas eleitorais permitem que os cidadãos escolham entre diferentes alternativas, em um ambiente desnivelado ${ }^{26}$.

Atualmente, os observadores eleitorais internacionais têm tido papel fundamental na indicação das más práticas que observam. Sobre as más práticas, LeDuc, Niemi e Norris (2014) argumentam que elas podem ser de primeira ou de segunda ordem, sendo os de segunda ordem passíveis de existir até mesmo nas democracias mais consolidadas. As más práticas de primeira ordem podem ser definidas como

“... aquelas nas quais há violência que leva à morte e que ferem direitos humanos fundamentais, sejam elas instigadas por forças de segurança estatais, governo ou partidos de oposição, líderes comunais, ou qualquer outro ator que imponha desafios à estabilidade do regime" ( $p$. 155)

Ao passo que, as más práticas de segunda ordem são

“... aquelas caracterizadas pelo mau uso da administração, falta de competência técnica, ou erro humano que destrói a integridade do processo eleitoral (...) podendo envolver desafios ao sistema legal e ainda pedidos por reformas, mas que não provocam conflitos com mortes" (p. 155).

\footnotetext{
25 Também é muita estreita a diferença entre as más práticas e conceitos como: má conduta eleitoral; corrupção eleitoral; abuso eleitoral e eleições fraudulentas. No entanto, as más práticas eleitorais abarcam um número maior de casos desviantes de standards democráticos em eleições e, por isso, foram escolhidas para a análise.

${ }^{26}$ Nesse sentido, dois exemplos merecem atenção. O primeiro é o caso venezuelano, que possui em sua constituição menção direta à observação internacional, chamada lá, de acompanhamento internacional. Em outras palavras a observação é restrita aos locais designados pelo governo, sendo a publicização e divulgação de informações, após a realização dos pleitos, restrita ao organismo responsável pela organização do processo eleitoral. Em outras palavras, é como se o país permitisse a observação, porém restringindo sua atuação. Mais recentemente, outro caso chamou a atenção. O presidente da Nicarágua Daniel Ortega decretou que não haveria mais observação eleitoral no país, embora a lei eleitoral do país a reconheça e que seja algo de responsabilidade do Conselho Supremo Eleitoral (CSE).
} 
Fato é que há uma grande diversidade de transgressões aos princípios democráticos, em termos de más práticas em processos eleitorais ao redor do mundo. Na América Latina não é diferente. Em geral, por trás das irregularidades estão os partidos no poder, que são os principais beneficiários destas práticas (Birch, 2011). Segundo Hoyos (2013), em muitos países latino americanos, não somente o partido no poder como também os partidos de oposição de maior peso político realizam, ou estão envolvidos com más práticas. De modo que, para a autora, todos os envolvidos no processo político se encontram envolvidos de forma direta ou indiretamente com práticas não condizentes às normas internacionais democráticas.

Assim, o monitoramento internacional de eleições busca ser um instrumento que contribua para a mudança de comportamento dos possíveis transgressores, em especial, ao tornar as más práticas um ato mais custoso e passível de ser punido (Simpser, 2008). Desse ponto de vista, o monitoramento pode levar a que os transgressores adotem condutas que sejam mais difíceis de serem descobertas, a exemplo da proibição de beber ao volante, que poder levar à diminuição de mortes de motoristas, sem que haja melhoria nas condições do trânsito em geral (idem).

Carothers (1997) e Bjornlund (2001) concordam que os pseudodemocratas (Hyde, 2011) se adaptaram à presença dos observadores. Os autores dizem que as tentativas de manipulação se tornaram mais sutis com o advento da observação e que os líderes passaram a promover más práticas em outras partes do processo eleitoral, sobretudo no período pré-eleitoral, em que é mais difícil a observação.

Para Simpser (2008), a maior regulação dos processos eleitorais não necessariamente leva à existência dos efeitos esperados. Destarte, a teoria da compensação, que segue a mesma lógica da condicionalidade/seletividade de financiamento internacional, por vezes induz a comportamentos inesperados dos governantes. Assim como o empregado que sabe em qual atividade deve empregar mais seus esforços - porque eles serão mensurados e, posteriormente, recompensados -, os líderes podem agir com vistas à prática de atividades que não podem ser avaliadas pelos observadores.

Beaulieu e Hyde (2009) afirmam que, na maioria das vezes, esta é uma tática empregada, principalmente, por autocracias eleitorais, com vistas ao 
recebimento de benefícios internacionais tangíveis, a exemplo de ajuda externa, ou, intangíveis, como reconhecimento internacional da legitimidade de seu governo. Muitos deles "incentivam a vinda de observadores internacionais e manipulam a eleição de forma que a torne menos propensa a críticas, isto é, manipulando-a estrategicamente" (p. 2).

Muitas vezes, a manipulação estratégica é encoberta, porém, há casos, nos quais a manipulação é observada, sem, no entanto, caracterizar uma fraude. Entre as táticas de manipulação visíveis estão: intimidação anônima ou violência contra candidatos da oposição; adulteração de listas de votação de eleitores; falha na entrega de material sensível em locais reconhecidos de maioria oposicionista; acusação de má conduta a observadores nacionais nãopartidários ou restrição a sua atuação nos colégios eleitorais; existência de muitos partidários de governo na comissão que administram as eleições; entre outros (idem).

Quando aplicadas, as más práticas mais perniciosas de manipulação eleitoral não são iguais para cada sistema político. Em democracias avançadas $^{27}$, por exemplo, o significativo desmantelamento de instituições políticas e imposição de limites à liberdade de imprensa, sairiam muito custosos a qualquer governo em exercício, ao passo que, em alguns países em desenvolvimento, as mesmas ações poderiam ser bastante atrativas (Simpser, 2008; Norris, 2013a). Isso ocorre porque em países em desenvolvimento o custo associado à manipulação estratégica pode não ser tão grande, ou seja, por vezes, os benefícios obtidos com más práticas podem ser mais vantajosos que aqueles de condutas democráticas, haja vista que as punições não serão tão graves.

Nos últimos anos, os líderes de países em desenvolvimento deixaram de praticar fraudes no sentido estrito do termo, para realizar a "manipulação que viola o espírito, se não, as instituições democráticas" (Beaulieu \& Hyde, 2009, p. 14).

\footnotetext{
27 Nas eleições presidenciais da Áustria, realizadas em maio de 2016, houve várias denúncias de manipulação dos votos por correspondência, que teriam sido abertos e ordenados antes da chegada de representantes da Comissão Eleitoral, significando possível adulteração a favor do candidato vencedor. Como resultado, a Corte de Justiça determinou a realização de novas eleições, porque o candidato ganhador obteve margem de vantagem de apenas 30 mil votos e os votos postais contabilizaram aproximadamente 740 mil.
} 
A violência, por exemplo, ainda que de difícil identificação de seus incentivadores é uma das táticas mais comuns atualmente. Ela está claramente fora de qualquer processo político democrático e tem um efeito imediato sobre a competição, uma vez que destrói o princípio da segurança das eleições ${ }^{28}$.

Como consequência, as missões de observação internacional têm a cada ano aperfeiçoado suas técnicas, com a inclusão, por exemplo, de mais critérios que um país deve seguir durante um processo eleitoral democrático e que demandam maior controle sobre a governança eleitoral. Entre elas: maiores demandas pela participação de minorias durante a votação; acessibilidade; inclusão de pessoas que não podem depositar seus votos nos centros eleitorais devido algum tipo de restrição na mobilidade; presos; expatriados; cidadãos que residem fora do país em que votam; etc.

Como resultado, a percepção de que uma eleição foi marcada por más práticas tende a diminuir a intenção de participação dos cidadãos em geral, uma vez que reduzem sua confiança no processo como um todo, e, comprometem a qualidade da democracia (Birch, 2011).

Freidenberg (2015) reconhece que os países latino-americanos alcançaram melhorias nesses setores, tendo as eleições dos últimos anos contado com condições mínimas de equidade, liberdade e justiça, com alternância de poderes e incorporação de setores excluídos (mulheres, indígenas e analfabetos, por exemplo). Porém, a autora afirma que os informes das missões de observação internacional demonstram que uma série de más práticas continuam a limitar sua integridade e qualidade.

\subsection{Considerações finais}

Finalizando, as eleições foram a forma mais utilizada na Terceira Onda de democracia para enfraquecer e acabar com os regimes autoritários. Mesmo os governantes autoritários tentaram renovar sua legitimidade através de eleições, seja devido a pressões da oposição, seja pela expectativa de assumirem a

\footnotetext{
${ }^{28}$ Em janeiro de 2016, o Haiti teve seu processo eleitoral suspenso com a recidiva de protestos violentos no país, em período pré-eleitoral à segunda rodada de votação, para escolha do novo presidente. Após os episódios foi instalada uma comissão técnica de verificação das eleições e um presidente provisório foi indicado pelo parlamento, com previsão de realização de novas eleições para outubro de 2016 e forte instabilidade política e social nas ruas.
} 
liderança do país uma vez mais, através de escolha popular (Huntington, 1994). Outros fatores ainda podem ser mencionados como: a necessidade de fazer reviver a legitimidade declinante no país, o predomínio de normas democráticas, globalmente e em sua sociedade, e o desejo de respeito e legitimidade internacionais" (idem, p. 181).

Entre as estratégias utilizadas para o seu reconhecimento internacional estavam as missões de monitoramento internacional, que através das abordagens das eleições livres, qualidade da democracia, integridade eleitoral e más práticas identificando os fatores que tornavam os processos políticos mais ou menos próximos dessas normas internacionais, aumentando ou diminuindo a legitimidade, no plano exterior e doméstico, desses novos regimes.

Não somente isso, muitas agências de financiamento internacionais passaram a condicionar sua ajuda aos países, mediante a comprovação de que os governos cumpriam com normas internacionais de boa governança, e, mais ainda, somente se essas regras de boa governança eram aplicadas nas eleições.

As abordagens que os observadores utilizam para avaliar os processos eleitorais pode variar, assim como seus métodos. Dessa forma, foram apresentadas as visões das missões de observação eleitorais internacionais, podendo ser aquela das eleições livres e justas, mais indefinida, e marca as eleições como um ponto de corte entre as democracias eleitorais e as autocracias eleitorais; da qualidade, que se centra nas realizações, utilizando-se de muitos critérios de avaliação; da integridade, que vê as eleições como um ciclo, em que devem ser mantidas boas práticas, que caso não cumpridas, levaria ao comprometimento de sua qualidade e; das más práticas, que são violações do ciclo eleitoral propriamente, através de práticas maliciosas como a manipulação.

Tem destaque no próximo capítulo as origens históricas do monitoramento internacional, com base na conjuntura internacional europeia, em que foram enviadas as primeiras missões para monitorar os plebiscitos de separação do continente, passando pelas descolonizações e chegando, anos depois, à sua versão moderna com as missões multidimensionais da ONU, focadas especificamente nas eleições de Estados recém independentes. Detalha ainda a ampliação no número de organizações internacionais voltadas 
para o tema somada a importância da América Latina como um espaço inicial de desenvolvimento das MOEls. 


\section{DOS REFERENDOS TERRITORIAIS À NORMA DE MONITORAMENTO INTERNACIONAL DE ELEIÇÕES: BREVE HISTÓRIA}

\subsection{Introdução}

O capítulo tem como objetivo mostrar a origem do desenvolvimento da observação internacional de eleições, a partir das primeiras experiências de monitoramento em espaços europeus, ainda no século XIX, passando pelos plebiscitos realizados em territórios ocupados pela Alemanha, pelas lutas de autodeterminação, criação da Liga das Nações, e, depois da Organização das Nações Unidas, até o surgimento das missões em países soberanos.

É discutido o avanço da Terceira Onda de democracia (Huntington, 1994) como um fator que impulsionou o aumento da observação, sobretudo na América Latina, mas não se limitando a essa região. Vale destacar a emergência de uma série de organizações internacionais voltadas à observação, como parte de suas estratégias de promoção da democracia.

A expansão da observação internacional de eleições ocorreu consoante a emergência de normas internacionais democráticas, reforçando a execução de boas práticas eleitorais, ao mesmo tempo em que, transformaram a observação em um mercado a autocratas eleitorais, interessados em legitimar seus governos, no cenário externo e doméstico.

\subsection{Fim da Primeira Guerra e reconfiguração do mapa europeu no apogeu dos referendos e plebiscitos territoriais}

Inicialmente se faz importante citar que a primeira experiência de consulta eleitoral sob monitoramento internacional teve no palco a Moldávia e a Valáquia (a última é atualmente província da Romênia), em 1857, sob o escrutínio dos Otomanos e das Grandes Potências europeias (Beigbeder, 1994) ${ }^{29}$.

A derrota da Rússia na Guerra da Crimeia (1853-1856) fragilizou o equilíbrio de poder europeu. Devido à posição estratégia na foz do Danúbio, canal que se tornara importante para as comunicações europeias, o status dos

${ }^{29}$ Anteriormente, jornalistas, acadêmicos, juristas e membros das embaixadas observaram eleições em países estrangeiros, porém sem uma função definida. 
principados da Moldávia e Valáquia se tornou uma questão importante no Congresso de Paris (1856), onde era negociada a paz após o fim da guerra.

Valáquia e Moldávia ainda estavam sob a suserania otomana, mas após - Congresso de Paris, foram colocados sob garantia coletiva das Grandes Potências que assinaram o Tratado de Paris (1856) - mais especificamente, Rússia, Prússia, Áustria, Grã-Bretanha, França, Sardenha e Império Otomano. Estes poderes resolveram, que assembleias locais deveriam ser convocadas para decidir sobre a futura organização dos dois principados. Segundo o próprio texto do Tratado: "nenhum tipo de proteção deve ser exercido sobre eles por nenhuma das grandes potências. Não deve haver nenhum tipo particular de interferência em seus assuntos domésticos" (art. 22).

De acordo com Wanbaugh (1920), a solução para a questão dos principados do Danúbio veio da Rússia, em 1855. A proposta russa foi incorporada ao Tratado de Paris, de 1856, na qual ficou estabelecido que a união ou manutenção da divisão entre os principados deveria ser realizada através de assembleias, com sufrágio limitado e indireto de delegados, sob a supervisão de uma Comissão Europeia.

Com a reunião das assembleias houve eleições na Moldávia e, depois, em Valáquia. Em 1859, depois de apurados os votos ficou estabelecida a união dos principados, sob o comando de um mesmo príncipe ${ }^{30}$. Era a primeira vez na história que o voto seria supervisionado por uma comissão internacional.

Embora este episódio marque a primeira experiência de monitoramento internacional de um processo eleitoral, ele não foi representativo de um movimento maior. Para Beigbeder (1994), a consulta popular sobre anexações não era prática comum no período, sendo mais recorrente a conquista e, depois, anexação de territórios. O autor cita a anexação pelos Estados Unidos de regiões como a Louisiana, Florida, Novo México, Califórnia e Alasca, como exemplos dessa tendência de apropriação, mais que de consulta (idem).

Com a assinatura do Tratado de Versalhes, em 1919, tem início a observação de internacional dos plebiscitos de muitas das possessões alemãs,

\footnotetext{
${ }^{30}$ Em 1863, Moldávia e Valáquia unificaram suas instituições, criando os Principados Unidos da Romênia. E em 1866, após a entrada em vigor uma nova constituição, o país mudou seu nome para Romênia, como permanece até hoje.
} 
que havia perdido a guerra, como: Schleswig, 1920; Allesntein, 1920; Marienwerder, 1920; Caríntia, 1920; Alta Silésia, 1921 e Sopron, 1921 (idem).

Em Schleswig, buscou-se definir como seria dividida a fronteira entre Dinamarca e Alemanha, sob a supervisão de representantes da França, Reino Unido, Noruega e Suécia. O resultado do plebiscito determinou que a maior porção do território disputado ao norte do condado fosse anexado à Dinamarca, enquanto que a menor porção, permaneceu como parte da Alemanha.

Em seguida, Allestein, antigo distrito da Prússia e, depois, cidade independente da Alemanha, foi palco de uma consulta popular para decidir se a região seria incorporada à Polônia ou se permaneceria com a Alemanha. Com a quase totalidade dos votos, ficou decidido que ela permaneceria como parte da Prússia. O mesmo ocorreu na região de Marienwerder, também dividida entre Prússia e Alemanha.

Na Caríntia, parte final da fronteira ao sul da Áustria, o plebiscito foi realizado com vistas a definir se algumas de suas regiões deveriam ser incorporadas ao novo reino dos sérvios, croatas e eslovenos. A proposta não foi aceita e definiu as fronteiras nessa parte da Europa até a Segunda Guerra Mundial, quando iugoslavos ocuparam a área. Sua desintegração deu origem à separação da Áustria e Eslovênia.

Também na Alta Silésia o plebiscito pretendia decidir sobre uma seção de fronteira entre a Alemanha e Polônia. Área com população dividida entre as duas nacionalidades, a Alta Silésia expressou em plebiscito a preferência pela separação da Alemanha, tendo seus moradores optado por se tornarem cidadãos poloneses.

Cidade no leste da Hungria com a Áustria, Sopron de população de maioria alemã, promoveu um plebiscito no qual ficou decidido que permaneceria como parte da Hungria.

Todos esses plebiscitos foram monitorados por uma comissão internacional de Aliados. Essa forma de observação eleitoral começa a mudar em 1935 quando a Liga das Nações surge como uma organização interessada no rearranjo territorial pacífico dos povos. São emblemáticos os casos das ilhas Aaland e Vilna e do Saar, sendo que no último houve envolvimento direto da Liga na organização e realização do seu plebiscito. 
As ilhas Aaland e Vilna foram alvos da disputa entre Finlândia e Suécia, fato que quase levou à guerra os dois países. O pedido de referendo foi submetido à Liga das Nações, que também monitorou o processo. Após a votação, foi decidido que as ilhas passariam a ser parte da Suécia (Beigbeder, 2011).

O Saar está localizado na fronteira entre Alemanha, França e Luxemburgo. OTratado de Versalhes colocou a região sob controle da Liga das Nações, por quinze anos (1919-1935). Após esse período, a Liga iniciou as preparações para a realização de um plebiscito, que iria decidir se seus habitantes desejavam fazer parte novamente da Alemanha, ou, se permaneceriam separados.

Segundo Wanbaugh (1920), a escolha por voto não poderia ser mais certa, pois muitos antinazistas tinham se deslocado para o Saar no ano de 1933. Vendo o que Hitler fazia na Alemanha, comunistas e socialdemocratas formaram uma coalizão favorável à manutenção da permanência do controle da Liga das Nações. Por outro lado, os alemães, decididos a recuperar a região, formaram uma coalizão com os católicos, para boicotar a consulta popular, ameaçando, inclusive, invadir o Saar e impor o regime nazista. Ao final, sob a observação de representantes da Liga, o plebiscito foi declarado livre e genuíno, com uma maioria de votos favoráveis ao retorno para a Alemanha.

Para Santa-Cruz (2013), os plebiscitos não eram a principal forma de resolução de conflitos fronteiriços, mas antes, uma prática marginal de estabelecer as fronteiras estatais. "Dos doze plebiscitos contemplados pelos tratados após o fim da Primeira Guerra, somente a metade deles foi realizada" (idem, p. 1732). No entanto, o plebiscito havia se transformado em um elemento central das relações internacionais, "tendo sido aceito como uma forma legítima de determinação de assuntos relativos à soberania" (ibidem, p. 1733).

Outro ponto importante, é que o princípio conhecido como autodeterminação, ainda que não constasse na Carta, passara a ser um guia importante para a Liga das Nações, na resolução de disputas territoriais, nos anos posteriores à Primeira Guerra. Naquele momento, a autodeterminação havia se tornado um princípio ad hoc, garantido somente aos Estados constituídos após o fim da Primeira Guerra. Os povos aos quais o princípio fazia referência eram somente aqueles grupos étnicos que tinham se mobilizado a 
nível nacional durante o século XIX, sob os impérios Austro-Húngaro, Alemão, Otomano e Russo.

A Liga das Nações, primeira organização internacional universal, foi estabelecida pelo artigo primeiro do Tratado de Versalhes (1919), embora suas bases tenham sido negociadas ainda durante o período do conflito mundial (1914-1919). Foi imaginada como uma entidade que poderia incluir todos os Estados soberanos que desejassem compor seus quadros e previa a substituição do equilíbrio de poder - modelo antes existente para manutenção da paz e ordem internacionais -, pelo sistema de segurança coletiva. Tal sistema estava baseado na decisão de um Estado usar a força somente em concordância com o estabelecido por um tratado multilateral de acordo com a interpretação de uma organização internacional, no caso, a própria Liga das Nações (Herz e Hoffmann, 2004).

O pensamento liberal passara a influenciar fortemente as relações internacionais do período, além de ter contribuído também para a própria criação da Liga, cujo maior expoente era o presidente estadunidense Woodrow Wilson (1913-1921). Terminada a Primeira Guerra, Wilson proferiu seu famoso discurso no Congresso estadunidense, em 11 de fevereiro de 1918, onde apresentou quatorze princípios para a garantia da paz. Entre eles, o décimo quarto ponto fazia referência à criação da Liga das Nações, com o intuito de fornecer garantias mútuas de independência política e integridade territorial aos grandes e pequenos Estados (idem).

Para ele, a Liga seria uma organização de Estados democráticos que viveriam em paz, algo já defendido por Kant em seu texto sobre a Paz Perpétua (1795). O filósofo prussiano defendia que as repúblicas democráticas formariam uma federação pacífica, sendo excluído o uso da força entre seus membros de uma forma duradoura e estável. Para ele ainda, a criação de uma comunidade de democracias federalistas levaria a relações mais pacíficas entre os Estados, uma vez que o governo seria controlado pelos cidadãos e estes não desejariam a guerra ${ }^{31}$.

\footnotetext{
${ }^{31}$ A noção de democracias pacíficas também foi utilizada por Schumpeter (1961) ao argumentar que o expansionismo imperialista e a guerra beneficiariam apenas uma minoria, sobretudo aquelas ligadas de fato à guerra, como as indústrias fornecedoras de armas e os setores militares.
} 
A criação dessa federação ou comunidade de Estados democráticos seria sustentada pelo princípio da autodeterminação. Em outras palavras, Wilson desejava que a democracia existisse não somente no plano doméstico, como também na arena internacional. "Ele desejava remodelar alguns poucos Estados já existentes, a partir do critério de respeito das nacionalidades, sem desafiar os poderes coloniais, exceto aqueles derrotados na Primeira Guerra (Beigbeder, 1994, p. 19).

Segundo o pensamento de Wilson, a autodeterminação permitiria que cada nação organizada na forma de um Estado contribuísse para a manutenção da paz, conforme princípios e valores democráticos universais comuns. A estabilidade de todo o sistema seria, dessa forma, muito mais provável de se consolidar efetivamente.

Sobre o tema, Dalton (2011) comenta que a autodeterminação, conforme o pensamento wilsoniano, compreendia aspectos domésticos e externos. $O$ primeiro corresponderia ao princípio filosófico relativo à garantia de que os povos são livres para escolher como suas vidas e o modo como se organizam serão estruturados, com base em suas próprias leis, normas e cultura. Já os aspectos externos dizem respeito à arena política internacional e envolvem a existência de um Estado independente, cuja nação é reconhecida externamente, com território, população e governos definidos.

Embora a Liga das Nações não tenha atingido seu objetivo principal, que era o da substituição do sistema de balanço de poder por aquele de segurança coletiva, ela deixou duas importantes contribuições. A primeira prendia-se ao surgimento de lutas de independência de uma série de Estados, que incluía obter o seu reconhecimento no sistema internacional, através de plebiscitos, referendos e eleições. Como consequência, o monitoramento de tais processos de consulta, como garantia de que princípio de autodeterminação havia sido respeitado, fosse aos olhos dos cidadãos que realizavam o pleito, ou mesmo, fosse frente à comunidade internacional. Entre os exemplos mais recorrentes de escolha popular monitoradas internacionalmente estavam aquelas das populações europeias, indicadas acima, que desejavam se conectar ou separar de outro Estado, além das colônias que buscavam se tornar independentes (idem). 
Apesar do desejo de Wilson de criar uma federação internacional de Estados democráticos, sob a premissa de que as democracias são naturalmente pacíficas, isto não ocorreu, já que muitos dos membros da Liga que eram admitidos, cumpriam esse requisito. Ou seja, muitos dos membros mesmo não sendo democráticos eram admitidos na Organização, o que contribuiu para seu fracasso.

A segunda contribuição diz à modificação nos conceitos de autodeterminação e de democracia, que passaram a abarcar os direitos humanos de forma mais incisiva.

O conceito de livre determinação dos povos passou a abranger não somente os habitantes das colônias e situação de emancipação colonial, como se estendeu a todos os povos. É a transformação do conceito, que antes estava mais restrito para um valor atribuível a todos os povos, que permitiu a observação internacional de eleições em países soberanos, anos mais tarde.

Segundo Franck (1992), a autodeterminação foi a pedra angular na criação de um direito dos povos à democracia, servindo como base sobre a qual foram criados vários novos Estados no sistema internacional.

O monitoramento internacional de eleições iria se intensificar no imediato pós-Segunda Guerra Mundial (1939-1945), com o aumento dos movimentos de descolonização e a emergência de uma série de organizações internacionais, a exemplo da Organização das Nações Unidas, Organização dos Estados Americanos e União Europeia (Beigbeder, 1994; Lansford, 2011b).

\subsection{Novos conceitos e novas práticas eleitorais: pós-Segunda Guerra}

Com o fracasso da Liga das Nações, os Aliados se viram com a tarefa de reconstrução da ordem mundial. Nesse contexto, surge uma nova proposta de um sistema de segurança coletiva, elaborada ainda durante a Segunda Guerra Mundial, resultado de um acordo entre União Soviética, Estados Unidos, China e Reino Unido. Os países entraram em consenso sobre a necessidade de uma organização universal, baseada no princípio da igualdade entre Estados soberanos, da qual estariam impedidos de participar: Alemanha, Itália, Japão e Espanha (Herz e Hoffmann, 2004). 
O texto básico que propunha a criação de uma organização multilateral universal foi analisada na Conferência de São Francisco, em abril de 1945, quando é criada, então, a Organização das Nações Unidas. Em outubro do mesmo ano, com a ratificação de sua Carta pela maioria dos países, a ONU passou a existir oficialmente (idem).

A organização intergovernamental passou a se ocupar da manutenção da paz no mundo através da criação de normas internacionais e, também, como um ator internacional, assumindo posições e produzindo ideias sobre a administração da segurança coletiva.

O próprio conceito de autodeterminação sofreu mudanças com a criação da nova organização. Cronin (2011) diz que o conceito passou a ter três significados principais, para além do ideal liberal-democrático wilsoniano, mas ainda com base nele. Primeiramente, a autodeterminação pode ser definida como o direito coletivo de uma comunidade linguística, étnica, cultural e religiosa de criar e administrar seu próprio Estado. Em segundo lugar, ela pode fazer referência ao direito de uma população de determinar o formato de suas próprias instituições políticas, econômicas e sociais. Por fim, o conceito tem sido associado às populações que desafiam o papel e influência de atores externos em seus governos e estruturas.

Após a criação da ONU, o princípio de autodeterminação dos povos foi formalizado internacionalmente, através de sua inclusão na Carta constitutiva da Organização. Era um momento no qual o colonialismo começava a colapsar. De um lado, havia o entendimento de alguns poderes coloniais de que 0 colonialismo não era algo mais factível ou sustentável, sobretudo daqueles que ainda mantinham colônias na África. Por outro lado, poderes coloniais como França e Portugal se recusavam a fazer o mesmo, gerando guerras e outros conflitos por autodeterminação, sobretudo, no Vietnã, Argélia, Angola, Moçambique e Rodésia (Zimbábue) (Herz e Hoffmann, 2004; Beigbeder, 2011; Cronin, 2011).

Beigbeder (1994) também identifica algumas tendências conflitantes no que concerne a atitude dos países quanto à aplicação do princípio de autodeterminação, nesse momento. Para ele, do ponto de vista dos países do grupo socialista, o autogoverno representava uma arma anticolonialista. Os países do Terceiro Mundo concordavam com essa interpretação do bloco 
socialista, acrescentando, ainda, que a autodeterminação também era antirracista. Já os países do bloco ocidental (Western group), defendiam a autodeterminação como o direito dos povos de escolher livremente seu regime político e governantes. "Eles consideravam a autodeterminação um critério fundamental para a legitimidade democrática de um governo (...) e inicialmente se opuseram, ou tentaram atrasar, os processos de autodeterminação em seus territórios coloniais" (idem, p. 19).

Mesmo a oposição dos países do bloco ocidental não impediu a realização de uma série de plebiscitos, referendos e processos eleitorais, que foram realizados com suporte da ONU.

Assim, logo após sua criação, as Nações Unidas foram convocadas a observar processos eleitorais em países divididos - em especial na Coreia -, em territórios tutelados e aqueles sem autogoverno, em geral transitando para a independência (Santa-Cruz, 2013; Beigbeder, 1994).

$\mathrm{Na}$ Coreia, Joseph Stalin acenou com a possibilidade de colocar o território sob tutela da União Soviética, no entanto, nenhum acordo foi feito. Durante a Conferência de Yalta (1945), foi aprovada uma tutela compartilhada entre Estados Unidos, Grã-Bretanha, União Soviética e China. No entanto, a tensão entre Estados Unidos e União Soviética começou a aumentar após novas ocupações do bloco socialista no Leste Europeu, o que contribuiu para o esfriamento das negociações. Finalmente, na Conferência de Moscou (1945), Estados Unidos, União Soviética e Grã-Bretanha, no âmbito das Nações Unidas, propõem uma nova tutela da Coreia, que é aprovada, com vistas ao estabelecimento de um governo provisório, até que novas eleições democráticas fossem convocadas.

Em 1948, tem palco um processo eleitoral ${ }^{32}$ para escolha da nova Assembleia Nacional coreana. Representantes da União Soviética e coreanas não seguiram a resolução imediatamente, sendo que as eleições, sob supervisão das Nações Unidas ${ }^{33}$, foram realizadas, de fato, somente no Sul, em

\footnotetext{
${ }^{32}$ As eleições só foram possíveis graças ao armistício entre os grupos separatistas da região, a exemplo do Exército Norte Coreano, negociada após ofensiva de forças militares multinacionais, do Comando das Nações Unidas (UNC). Por sua vez, o armistício foi supervisionado pela Comissão das Nações Unidas para a Unificação e Reabilitação da Coreia (UNKURK) e as eleições tiveram observadores da Comissão das Nações Unidas para a Coreia (UNCOK).

${ }^{33}$ Segundo Beigbeder (1994), apenas dezoito observadores das Nações Unidas estiveram no Sul da Coreia para observar as eleições, que ao final foram consideradas legítimas.
} 
agosto, dando origem à República da Coreia (Coreia do Sul). Em setembro, a República Democrática da Coreia (Coreia do Norte) foi estabelecida no Norte.

Conforme Beigbeder (2011), entre os processos de escolha popular levados à cabo em territórios sob tutela das Nações Unidas ${ }^{34}$ e aqueles sem autogoverno, sob o princípio da autodeterminação e também com supervisão da ONU, nos anos imediatos após a Segunda Guerra, podem ser mencionados: Togolândia (1956); Camarões Britânica (1959); Samoa Ocidental (1961); Ruanda-Urundi (1961); Guiné Equatorial (1968) etc.

A ONU teve um papel de destaque na condução de observações em plebiscitos de autodeterminação. Naquela época ocorreu a formação, então, da primeira geração de observadores para monitoramento dos processos eleitorais em todo o mundo, sendo sua principal preocupação "assegurar que a transferência de poder de governantes coloniais para líderes nacionais fosse realizada de forma livre e justa" (Lappin, 2009, p. 87).

Ademais, a supervisão de processos eleitorais ocorreu de forma frequente no contexto das operações de descolonização. Nesses casos, as operações das Nações Unidas visavam não somente certificar o resultado das eleições, através de um representante especial do Secretário-Geral, como também, confirmar a validade de aspectos cruciais ao processo eleitoral, como a verificação da participação popular e a validade dos votos.

Com vistas à promoção do autogoverno em territórios coloniais, a Assembleia Geral das Nações Unidas, aprovou, em 27 de novembro de 1953, a resolução 742 (VIII) na qual determinava os fatores através dos quais seria atingido tal objetivo. "Também propunha uma série de alternativas ao status colonial - as quais deveriam ser escolhidas através de meios democráticos pela população dos territórios em questão" (Santa-Cruz, 2013, p. 1733).

Entre os fatores indicativos de que um território havia alcançado sua independência, que constavam na resolução, estavam: (1) relações internacionais, ou seja, poder manter relações de todo o tipo com outros governos e com instituições internacionais e capacidade de negociar, assinar e

\footnotetext{
${ }^{34}$ Os territórios sob tutela eram os antigos mandatos da Liga das Nações, que após seu fim, em 1946, passaram a ser administrados pelas Nações Unidas. Já os territórios sem autogoverno são aqueles cujo governo não atingiu plena capacidade se auto governar, segundo própria definição da Organização.
} 
ratificar instrumentos internacionais; (2) forma de governo, que corresponde à completa liberdade da população de um território de escolher a forma de governo que desejar; (3) sufrágio igualitário, com a realização de eleições, caracterizadas pela ausência de influência ou coerção sobre votantes; (4) participação da população no governo do território, com sistema eleitoral representativo e conduzido sem a interferência direta ou indireta de um governo estrangeiro etc. (ONU, Resolução 742 (VIII), 1953).

No entanto,

“... como no período entre guerras, o uso de plebiscitos ou referendos monitorados por organizações internacionais não era uma regra geral. Em muitos casos, os poderes coloniais permaneciam no controle dos processos eleitorais que levavam à independência, sem solicitação de envolvimento das Nações Unidas. Mesmo assim, as Nações Unidas supervisionaram aproximadamente trinta votações em territórios sob tutela e em autogoverno" (Santa-Cruz, 2013, p. 1733).

Com a aprovação da Carta, os membros das Nações Unidas acordaram que "a governança de um país deveria estar de acordo a princípios e práticas democráticas, para que fosse legitimado" (Beigbeder, 1994). Eleições livres, periódicas e universais, com sufrágio igualitário e voto secreto, eram, portanto, determinantes para definir se uma democracia havia sido estabelecida ou se renovado.

Em democracias mais antigas e estáveis, esse era um objetivo mais fácil de ser atingido, pois estruturas legais, constitucionais e administrativas já haviam se consolidado, sendo os desvios, fraudes e outras irregularidades, facilmente revertidas pelos conselhos eleitorais e outros órgãos. No entanto, em se tratando de territórios que lutavam para se tornar independentes, através de plebiscitos ou referendos de autodeterminação, havia o risco de que tais processos eleitorais fossem organizados pelo poder colonial.

Tanto nesses casos, quanto naqueles de países que transitam de um governo autoritário para democracia, como será visto mais à frente, "autoridades foram aconselhadas ou persuadidas a recorrer ao monitoramento internacional" (idem, p. 13). Isso porque o monitoramento internacional emergiu como uma das várias estratégias de resolução de conflitos e se tornara uma parte importante dos acordos de paz e também das operações de manutenção da paz das Nações Unidas (Sebudubudu, 2011). 
Outro fenômeno sistêmico teria também bastante proeminência no processo histórico de surgimento das missões de observação eleitoral internacionais

\begin{abstract}
“... as grandes guerras, o desenvolvimento econômico, as inovações tecnológicas e o próprio crescimento do número de Estados no sistema internacional, a partir da desagregação dos impérios, favoreceram um enorme crescimento do número de Organizações Intergovernamentais Internacionais (OIGs) e Organizações Não-Governamentais Internacionais" (Herz e Hoffmann, 2004, p. 37).
\end{abstract}

Assim, além das Nações Unidas, no âmbito multilateral, proliferaram organizações intergovernamentais regionais, a exemplo da Comunidade Europeia, criada em 1957; da Organização dos Estados Americanos, em 1958 e da Organização de Unidade Africana (atualmente União Africana), em 1963. Estas organizações regionais eram fruto de um processo político que teve início no imediato pós-Segunda Guerra, sendo importantes para a manutenção da segurança coletiva no plano regional. Assim, vê-se que a administração da segurança internacional passara a ser realizada também no âmbito regional, como contemplada pelo Capítulo VIII, da Carta das Nações Unidas (idem).

Também após o fim da Segunda Guerra teve início a uma segunda onda de democratização, conforme Huntington (1991; 1994), que atingiu seu pico em 1962, quando trinta e seis países passaram a ser governados democraticamente, contribuindo também para o início das práticas de observação internacional de eleições em países para além daqueles tutelados pelas Nações Unidas (idem).

As Nações Unidas adotaram a democracia como um elemento para a consolidação da paz, no âmbito das suas operações de paz, a partir da segunda e terceira gerações. Segundo Kenkel (2013) podemos dividir as operações de paz da ONU em cinco fases. A primeira fase, ou geração, foi marcada pelo envio de contingentes militares pequenos para auxiliar na construção da paz, em países que estavam em conflito devido disputas pela posse de territórios, a exemplo da missão que foi enviada para Índia e Paquistão, em 1948. Em seguida, a segunda geração, surgida com o fim da Guerra Fria, visava tarefas mais para a área política, e envolvia atividades como a organização de eleições, promoção de direitos humanos e assistência a refugiados. A terceira geração estava focada na imposição da paz, com pouca diferença com relação às atividades que realizavam na segunda geração, porém com maior permissão 
para o uso da força, em meados dos anos 1990. A quarta geração se voltou para a construção da paz, com esforços no sentido de consolidar e solidificar a paz, evitando a reincidência de conflitos, a partir do início do século XXI. Por fim, a quinta geração, que é a mais atual, é mais especializada que as demais e têm tarefas, que vão do auxílio à reconstrução de países, a exemplo da Missão das Nações Unidas para a Estabilização do Haiti (Minustah), até a manutenção da paz em ambientes de escalada e violência.

Em suas operações de paz multidimensionais, das chamadas segunda (fim da Guerra Fria) e terceira gerações (meados dos anos 1990), a democracia passou a operar como um imperativo internacional. Essas operações tinham como um de seus objetivos principais promover a democratização do país na qual a Organização intervinha. De modo que, "a internacionalização do ideal democrático caminhou lado a lado com a implantação das missões de assistência e observação eleitorais" (Crochetet, 2013), por parte de organizações internacionais, a exemplo das Nações Unidas, através de suas operações de paz multidimensionais.

Conforme Kenkel (2013), as missões de paz das Nações Unidas no pósGuerra Fria passaram a ter como características principais a adição de tarefas civis relacionadas à transição política, "sem um aumento concomitante da permissão para uso da força militar" (p. 128). Para ele, "as missões típicas de segunda geração (...) envolviam a organização de eleições (como aspecto fundamental para a transformação de um conflito violento em contestação política (...) e construção de capacidade de governo" (p.129). Entre as principais missões estabelecidas com esse intuito, estavam: o Grupo de Assistência Transitória das Nações Unidas para a Namíbia (UNTAG) (1989-1990) e a Operação das Nações Unidas em Moçambique (UNOMOZ) (1992-1994).

\subsection{Avanço da Terceira Onda e criação de novas organizações internacionais voltadas à assistência eleitoral}

Para além da atuação das Nações Unidas, outra característica importante do período é o aumento no número de organizações internacionais que passaram também a realizar o monitoramento de eleições. 
A taxa de eleições observadas internacionalmente continuou muito baixa até o início dos anos 1970. Com algumas exceções, essas missões pioneiras enviavam, em média, um ou dois observadores às capitais, com pouca ou quase nenhuma crítica ao processo em si (Hyde, 2011).

Como observa Huntington (1994), à medida que a Terceira Onda avançava, a democratização se tornava um fenômeno reconhecido na política internacional, "os meios de comunicação deram mais atenção a ela e as eleições passaram, cada vez mais, a ser motivo de monitoramento internacional" (p. 184).

Na América Latina, em geral, o início da Terceira Onda foi marcado pela realização de eleições, porém, sem democracia. Muitos governos autoritários passaram a realizar eleições, com a esperança de se perpetuarem no podes. "Muitas vezes no passado conseguiram fraudá-las silenciosamente, de maneiras não-óbvias, de modo que, embora todos soubessem que as eleições eram fraudadas, ninguém podia provar" (Huntington, 1994, p. 184). Assim, muitos governantes realizaram eleições fraudulentas (Guiana, 1968 e 19 73; Haiti, 1957 a 1971; República Dominicana (1966, 1970 e 1974); ou nem mesmo a realizavam, como no Chile, entre 1973 e 1989; a Argentina, entre 1973 e 1983; o Uruguai, entre 1971 e 1984 e o Brasil, entre 1964 e 1985 (Lean, 2007) ${ }^{35}$.

A situação começou a mudar entre os anos 1960 e 1970, quando a OEA passa a enviar delegações multilaterais de observadores diplomáticos intensificando esta prática nos anos 1980, quando muitos regimes autoritários começam a liberalização. As missões de observação mudaram seu caráter, passando de uma natureza diplomática para uma mais voltada à assistência eleitoral (idem).

Em 1962, o monitoramento internacional passou a ser de fato praticado nas Américas, quando três delegados da Organização dos Estados Americanos observaram as eleições da Costa Rica (Lean, 2007). As eleições gerais da Costa Rica foram o primeiro caso divulgado de uma missão internacional em país soberano, seguida dez meses depois pela observação da OEA nas eleições gerais da República Dominicana (Hyde, 2006). A missão enviada ao país foi

\footnotetext{
${ }^{35} \mathrm{~A}$ taxa de eleições observadas internacionalmente continuou menor que $5 \%$ até o início dos anos 1970. Com algumas exceções, essas missões pioneiras enviavam, em média, um ou dois observadores às capitais, com pouca ou quase nenhuma crítica ao processo em si (Hyde, 2011).
} 
caracterizada como uma missão de assistência eleitoral, mas na realidade consistiu no monitoramento das eleições de 1962 (Hyde, 2011).

Mais especificamente, a chamada primeira fase do monitoramento internacional de eleições na América Latina que vai de 1962 até 1977, era predominantemente marcada pela oposição dos governantes à atuação de missões de observação, por acreditarem que elas poderiam ser prejudiciais à soberania dos países, já que as eleições, eram um assunto estritamente doméstico (Santa-Cruz, 2007; 2013; McCoy, 1998).

Entre 1978 e 1989, com a inserção de novos atores no cenário internacional, sobretudo as organizações internacionais não governamentais (OINGs) e as organizações internacionais intergovernamentais (Olls), inicia-se uma segunda fase do monitoramento internacional de eleições na América Latina que foi marcada pela mudança na forma como os países da região compreendiam o conceito de soberania.

Segundo Santa-Cruz (2005), o início dos trabalhos das OINGs e das Olls nos anos 1980 pode ser considerada a segunda fase segunda fase do monitoramento internacional de eleições na América Latina pela mudança nas estruturas das missões, tornando-as bem mais estruturadas. $O$ tamanho das missões aumentou, assim como o trabalho realizado por elas, porque o trabalho das equipes era muito mais exaustivo que aquele realizado pelas delegações características da primeira fase. Muitas dessas novas organizações se basearam nas práticas que as precederam, como aquelas das missões da OEA. Quatro são os argumentos utilizados por aqueles que defendem o direito à governança democrática, ao justificar o monitoramento internacional de eleições, em países soberanos. São eles: (1) o conceito de soberania é em si sujeito a mudanças, como respostas à condições novas, postas tanto no cenário externo, quanto no cenário doméstico; (2) o monitoramento eleitoral reforça a legitimidade doméstica de um governo e fortalece sua soberania externamente; (3) a verdadeira soberania reside nos cidadãos, não no Estado, assim, uma vez que os observadores buscam fortalecer os indivíduos, suas atividades são consistentes com a soberania e; finalmente, (4) Estados não são agentes livres, mas sujeitos à limitações derivadas do direito natural de seus cidadãos, assim como limitações legais, por ele contratadas sob uma série de tratados 
internacionais de direitos humanos, na qual estão incluídos direitos como o de eleições livres (Chand, 1997).

Santa-Cruz (2007; 2013) fundamenta seu argumento na primeira proposição dos defensores da boa governança democrática, ao enfatizar que a maior comunicação entre atores nacionais e internacionais fez com que conceitos tradicionais de soberania, marcados pela oposição entre o doméstico e o internacional, fossem desafiados. Isso porque, cada vez mais, esses atores estavam unidos em torno de problemáticas próximas, a exemplo da defesa dos direitos humanos e promoção de valores democráticos comuns (idem).

Lean (2007, p. 162), por sua vez, argumenta que "a transnacionalização do monitoramento de eleições, foi um importante passo na mudança da dinâmica do monitoramento eleitoral, que passou de uma intervenção externa, para uma forma de validação internacional".

Sobre essa questão é importante mencionar o papel desempenhado pelos presidentes dos Estados Unidos à época da Guerra Fria. Embora Dwight D. Eisenhower (1953 -1961) tivesse sido aliado de vários líderes autoritários contrários à expansão comunista, a despeito do comprometimento destes com a promoção da democracia, isso começou a mudar em início dos anos 1960, quando os Estados Unidos suspenderam suas relações diplomáticas e impuseram sanções econômicas a Cuba e República Dominicana. Quando John F. Kennedy (1961-1963) iniciou sua gestão, o apoio à governos democráticos e pressão para o fim de regimes comunistas, já era parte de sua política externa. Kennedy manteve a mesma política adotada por Eisenhower com relação a Rafael Trujillo (1930-1961), na República Dominicana, e aumentou as pressões para democratização do Haiti, que estava sob o comando de François Duvalier (1957-1971) (Hyde, 2011). Segundo Carothers (2011, p. 20),

\footnotetext{
“... o presidente Kennedy e seu time acreditavam que os Estados Unidos possuíam capacidade única, assim como o dever e destino de fazer o bem no mundo. Eles estavam certos de que com a quantidade ideal de energia e recursos, poderiam ajudar as nações americanas do Terceiro Mundo a sair da pobreza e da ditadura, em direção à democracia".
}

Embora o país fosse visto com certa apreensão pelos vizinhos latinoamericanos, em função de uma série de intervenções para conter a expansão do comunismo, promovidas pelos presidentes estadunidenses na região anos antes, Jimmy Carter (1976-1980) assumiu a liderança dos Estados Unidos com 
a intenção de propor novas estratégias. Crítico da posição de seus antecessores que apoiaram regimes autoritários, Carter preferiu alinhar a assistência estadunidense à proteção dos direitos humanos e democracia, eliminando qualquer assistência militar a países como Argentina, Brasil e Chile, que mantinham regimes autoritários (Shaw, 2007; Huntington, 1994).

Além de Carter, novos atores, como as Olls passaram a atuar na promoção da democracia, em especial realizando o monitoramento de eleições. Em 1978, o Escritório de Washington para a América Latina (WOLA) iniciou suas atividades de monitoramento na Bolívia. Assim como outros grupos surgidos à época, o WOLA aproveitou o momento aberto pelo período eleitoral para investigar casos específicos envolvendo denúncias de violações de direitos humanos, sendo a observação uma atividade secundária (McCoy, 1998).

Governos autoritários que se mostravam relutantes em receber ativistas de direitos humanos estavam, no entanto, à procura de observadores internacionais para suas eleições. Com essa janela de oportunidade aberta, muitos grupos internacionais de direitos humanos acabaram por participar das missões com o intuito maior de recolher informações sobre abusos cometidos contra os direitos humanos no país que os convidara, sendo que, em outras ocasiões o mesmo acesso lhes seria negado (idem).

Deve ser agregado a esse cenário, ainda, a chegada de Ronald Reagan (1981-1989) à presidência dos Estados Unidos. Seus esforços, assim como o das organizações internacionais, se direcionaram para que a promoção da democracia fosse um dos principais eixos de seu governo, principalmente no direcionamento da política externa estadunidense. De forma a materializar o discurso presidencial, o Congresso criou, em 1983, a Fundação Nacional para a Democracia (NED), cujo mandato incluía o envolvimento dos Estados Unidos em "programas de formação democrática e construção institucional democrática externa" e "fortalecimento de processos eleitorais democráticos com parceiros domésticos" (Jason, 1991, p. 1827).

O NED se tornou bastante ativo e, apesar de sua ligação com o país, foi estabelecida como uma organização privada, sem fins lucrativos, bipartidária, para fortalecimento das instituições democráticas em todo o mundo. A maioria das ações de promoção de democracia que apoia são executados pelo Instituto Democrático Nacional (NDI) e o Instituto Republicano Internacional (IRI), ambos 
estabelecidos no mesmo ano do NED e afiliados aos partidos Democrático e Republicano, respectivamente (idem).

O Centro Carter (CC) foi outra importante organização criada durante a administração Reagan e que possui ligações com o governo estadunidense. Criada em 1982, o Centro liderado pelo ex-presidente Jimmy Carter, realizou sua primeira observação no Haiti, em 1987.

O Grupo de Direito Internacional para os Direitos Humanos (ou International Human Ringts Group, IHRLG) também estabeleceu seu Projeto de Observação Eleitoral, em 1983, com parcerias domésticas nos países em que realizou observação. Em 1984, o grupo publicou as Diretrizes para a Observação Eleitoral Internacional, cujo texto se tornou uma referência tanto para OINGs, quanto para IIOs (Santa-Cruz, 2007).

Segundo Huntington (1994, p. 184), "o surgimento e difusão do fenômeno do observador estrangeiro foi um grande desenvolvimento dos anos 80 e aumentou significativamente a importância das eleições no processo de democratização" ${ }^{36}$. Os governantes autoritários não tinham outra alternativa, senão promover eleições. Caso tentassem manipular o jogo eleitoral, perderiam legitimidade e, mesmo se tentasse manipulá-la, teriam de fazer isso de forma extrema, o que também não Ihes garantiria muitas vantagens, visto que a oposição ganhava força a cada dia. Ademais, "governantes autoritários só conseguem legitimar seu regime quando são retirados através de eleições" ( $p$. 185), qualquer outra situação levaria a resultados inesperados.

Assim, a partir de 1989, tem início a terceira fase do desenvolvimento do monitoramento internacional de eleições, com o envio de uma das maiores missões de observação a um país soberano, nomeadamente, a Nicarágua. Segundo Kumar (1998), o governo sandinista convidou as Nações Unidas, a OEA, o Centro Carter e outras, para monitorar o processo eleitoral que se realizaria em 1989, se tornando o primeiro país soberano a aceitar esse tipo de monitoramento (Kumar, 1998; Pastor, 2002; Hyde, 2006).

Conforme Huntington (1994), a escolha por realizar eleições, por parte de governos fechados, se dava, principalmente, "pela noção de fazer reviver sua legitimidade declinante no país, o predomínio de normas democráticas,

36 Governantes de países soberanos, fora da América Latina, também começaram a solicitar observação internacional de eleições, a partir dos anos 1980 (Hyde, 2011). 
globalmente e em sua sociedade, e o desejo de respeito e de legitimidade internacionais" (p. 181)

Para Hyde (2006), de forma diferente das primeiras missões, que contavam com uma delegação de apenas um ou três observadores ao longo do dia da eleição, à medida que a promoção da democracia passou a ser parte fundamental da agenda de política externa de muitos países ocidentais e, conforme muitos líderes de países em transição eram incentivados a provar seu compromisso com a democracia ${ }^{37}$, " a qualidade da observação eleitoral mudou drasticamente" (p. 31).

Por isso, "mesmo antes de o processo eleitoral na Nicarágua terminar, a OEA iniciou a produção de uma série de novos instrumentos diplomáticos ou ferramentas que dariam suporte à nascente norma de monitoramento internacional de eleições" (Santa-Cruz, 2007, p. 147). Entre eles, estava a proposta do Canadá de criação de uma Unidade de Promoção da Democracia (UPD), aprovada em 1990, e que seria responsável por servir de alicerce ao desenvolvimento democrático nos estados membros, fornecendo assistência na preservação e fortalecimento das instituições políticas e nos procedimentos democráticos (OEA, 1990) ${ }^{38}$.

Logo em seguida, a Secretaria Geral da OEA aprovou a Resolução 1080, mecanismo com o objetivo de responder às crises democráticas na região, sobretudo quando havia violação ao Estado de Direito. A Resolução se direciona, especificamente, à convocação de um encontro de emergência entre os membros do Conselho Permanente quando da interrupção de forma irregular ou abrupta de processos institucionais político democráticos, em referência, basicamente, à golpes de Estado (OEA, 1990). No ano seguinte, a Assembleia Geral aprovou o Protocolo de Washington (1992), com a intenção de estabelecer a suspensão de um país membro, caso fosse verificada a retirada à força de um governo democraticamente eleito. Por fim, em 2001, a Organização adotou o

\footnotetext{
37 Para os líderes já comprometidos com a promoção da democracia, a decisão de convidar observadores era determinada pelas suas aspirações a receber benefícios internacionais, enquanto que, aos governantes não democráticos (ou pseudo-democratas), a decisão estava baseada nos benefícios potenciais que poderiam receber de financiadores da democracia (Hyde, 2011).

38 Desde sua criação o UPD, que depois passou a ser denominado Departamento para a Promoção da Democracia (DPD) e atualmente Departamento para a Cooperação e Observação Eleitoral (DECO), já observou mais de cem eleições nas Américas, desde sua criação.
} 
Quadro Interamericano Democrático (IADC), uma extensão da Resolução 1080, que aumenta a concepção sobre o que constitui uma crise democrática, que passara a envolver, qualquer forma de ação inconstitucional contra um governo eleito de forma democrática.

As Nações Unidas também criaram uma divisão, no âmbito do Departamento de Assuntos Estrangeiros (DPA), denominada Divisão de Assistência Eleitoral (EAD), especializada no monitoramento internacional de eleições, porém não com parte de ações voltadas à resolução de crises, mas antes como parte de suas estratégias de manutenção da paz (peacekeeping) ${ }^{39}$. Segundo a EAD, "como as eleições desempenham um importante papel em processos de paz e transições políticas destinadas a acabar com o derramamento de sangue, ou de estabelecer ou restabelecer a governabilidade democrática, a assistência eleitoral é uma área de crescente responsabilidade e competência" (UN, 2016) ${ }^{40}$.

De modo a melhorar a eficácia do princípio de eleições periódicas e legítimas (ONU, 1991: AG/RES - 45/150), respeitando o princípio da soberania nacional e da não ingerência nos assuntos internos dos Estados em seus processos eleitorais (ONU, 1991: AG/RES - 45/151), a ONU fortaleceu sua participação na área eleitoral, com base em normas universais democráticas.

Para as Nações Unidas, sua assistência eleitoral deve: dar auxílio aos seus Estados membros para que eles possam levar adiante processos legítimos e autênticos, conforme critérios internacionais e contribuir na construção de capacidade institucional dos países que solicitarem a assistência eleitoral e para a organização de processos eleitorais democráticos periódicos que possam ser vistos com confiança, tanto pelo eleitorado, como pelos partidos em disputa (Goodwin-Gill, 2006).

\footnotetext{
39 O Programa das Nações Unidas para a Promoção do Desenvolvimento (Pnud) também colabora com a EAD nos projetos de assistência eleitoral, auxiliando na construção de estratégias, facilitando a observação internacional e fornecendo especialistas, caso seja necessário.

${ }^{40}$ Após sua criação, a Divisão de Assistência Eleitoral (EAD), passou a oferecer assistência eleitoral, observação internacional e organização e supervisão de eleições, sendo que, nos últimos anos, a assistência eleitoral cresceu exponencialmente, superando os pedidos de observação e outros. Segundo Goodwin-Gill (2006), isso ocorreu porque, no âmbito da Organização, as eleições se tornaram parte significante de esforços de manutenção e construção da paz em países que saíram de conflitos, em que é difícil mesmo a organização dos pleitos, mais que seu reconhecimento.
} 
Assim, a partir de 1990, outras organizações internacionais passaram a oferecer assistência eleitoral, com o envio de observação técnica, por parte de magistrados e/ou funcionários de organismos eleitorais da região. O Instituto Interamericano de Direitos Humanos (IIDH), também participou do movimento de maior institucionalização das ações de promoção da democracia, no que tange as eleições, ao criar, em 1983, o Centro de Assessoria e Promoção Eleitoral (CAPEL), cujos trabalhos tiveram início em 1985.

O CAPEL se consolidou como um centro de apoio e consolidação do trabalho de fortalecimento dos processos e instituições democráticas. Desde 1991, serve como Secretaria Executiva da União Interamericana de Organismos Eleitorais (UNIORE) ${ }^{41}$, que tem como alguns de seus objetivos: estimular a participação de representantes dos organismos membros, na qualidade de observadores, nos processos eleitorais, para os quais a União for convidada e promover sistemas eleitorais seguros, eficientes e democráticos, através dos quais sejam garantidas a emissão dos votos de forma livre, universal e secreta (UNIORE, 1991).

Por fim, é importante citar a Fundação Internacional para os Sistemas Eleitorais (IFES) criado em 1987 e que realizou muitas observações na América Latina e em outras regiões, através de missões conjuntas, logo após sua criação, além de também fornecer assistência eleitoral.

Hyde (2006) argumenta que para além da América Latina, a observação se expandiu, em meados dos anos 1990 para Ásia, África, Leste Europeu e o Caribe, quando foram criados programas específicos para cada uma dessas áreas. Desde então, a observação alcançou todas as regiões do mundo, passando a ser algo realizado de forma separada da assistência eleitoral.

De uma forma mais geral, a Comissão Europeia (2006) define a assistência eleitoral como o componente técnico ou apoio material ao processo eleitoral. Essa ajuda pode se dar através do fornecimento de auxílio profissional para o estabelecimento de um quadro jurídico para as eleições; fornecimento de materiais e equipamento de voto; ajuda no registro dos partidos políticos e do registro de eleitores; apoio a ONGs locais e sociedade civil organizada em áreas

\footnotetext{
${ }^{41}$ De acordo com Carrillo (2007), o Capel desempenhou papel chave na América Latina ao criar associações de organismos eleitorais na América Central (Protocolo de Tikal, de 1985), na América do Sul (Protocolo de Quito, de 1989) e, em todo o continente americano (Uniore, 1991).
} 
como educação cívica e formação técnica de observadores domésticos; bem como o apoio aos meios de comunicação através de acompanhamento e formação de jornalistas.

A observação eleitoral constitui o complemento político da assistência eleitoral, sendo definida como "a coleta intencional de informações relativas a um processo eleitoral, e a elaboração de julgamentos consistentes sobre a condução de tal processo com base nas informações recolhidas, por pessoas que não são inerentemente autorizados a intervir no processo" (idem, p. 6). De uma forma geral, a observação eleitoral é parte da assistência eleitoral. Mais estreitamente, são atividades diferentes que podem e devem ser programadas de maneira complementar

A observação eleitoral internacional baseia-se nos princípios de total cobertura do processo eleitoral, imparcialidade, transparência e profissionalismo. O seu objetivo máximo é fortalecer a democracia, através da criação de capacidades nacionais, além de outros como atribuir legitimidade a um processo eleitoral, quando apropriado; aumentar a confiança do público no processo eleitoral; evitar fraudes, reforçar o respeito pelos direitos humanos, e contribuir para a resolução de conflitos relativos ao processo eleitoral.

Entre os fatores que podem ser apontados para a emergência das várias missões realizadas a partir dos anos 1990 está a ampliação da observação internacional, como uma forma de apoio à democracia e, particularmente, a ampliação no número de eleições, conforme normas democráticas internacionais, como será visto em seguida.

\subsection{Expansão do monitoramento internacional de eleições: emergência de normas democráticas globais}

Para Flores (2013), conforme avançara a Terceira Onda, as eleições cresceram em número e importância, vindo a simbolizar não a apoteose de uma transição democrática, mas antes, o primeiro passo de um caminho incerto para uma mudança de regime. Nesse caminho incerto, a observação se tornou central, como parte dos processos eleitorais de muitos países ao redor do mundo, em especial, das democracias emergentes (Sebudubudu, 2011). 
Em sua essência, a observação internacional de eleições é "o processo através do qual atores externos e não-envolvidos na votação, a avaliam" (Lansford, 2011b). Em outras palavras, corresponderia à "coleta de informações com relação a um determinado processo eleitoral e tomada de decisões informadas sobre sua condução, com base nas informações recolhidas, por pessoas que não são autorizadas a nele intervir" (Sebudubudu, 2011).

E, de forma mais completa,

“... a observação internacional é: uma sistemática, compreensiva e apurada reunião de informações relativas às leis, processos e instituições relacionados à condução de eleições e outros fatores relevantes ao ambiente eleitoral de um modo geral; a análise imparcial e profissional de tais informações; e as conclusões sobre o caráter dos processos eleitorais, com base nos mais altos padrões de exatidão das informações e imparcialidade da análise. A observação internacional de eleições deve, quando possível, oferecer recomendações para a melhoria da integridade e efetividades dos processos eleitorais e correlatos, embora sem interferir ou entravá-los" (ONU, 2005, p. 2).

Ao passo que,

“.... as missões de observação eleitoral internacionais são: os esforços organizados de organizações internacionais intergovernamentais ou não-governamentais e associações para realizar a observação eleitoral internacional" (idem, p. 2).

Sendo os observadores internacionais,

“... pessoas competentes em matéria eleitoral que tem por missão monitorar de perto o desenvolvimento, em um país, de seu processo eleitoral, com vistas a verificar se tal processo foi realizado respeitando condições de liberdade, regularidade e honestidade conforme normas relevantes de direitos humanos" (Vasak, 2000, p. 299).

Os observadores internacionais se dividem ainda entre aqueles de longo e curto períodos. Os primeiros realizam a observação ao longo de todo 0 processo eleitoral, ou seja, antes, durante e depois das eleições, enquanto os observadores de curto período participam de uma reunião preparatória e chegam ao país de destino alguns dias antes do dia da eleição retornando aos seus países de origem alguns dias depois. Há uma presença massiva de observadores de curto período, de modo a compensar por sua pequena estadia no país que realiza o pleito, além de serem distribuídos por todas as regiões em que há centros eleitorais.

Nos últimos anos, o monitoramento se tornou "uma forma de fazer cumprir direitos políticos consagrados em convenções internacionais" (Chand, 1997, p. 
559), como consequência, passou a ser um elemento fundamental no regime internacional de proteção da democracia.

Conforme pesquisa experimental de Donno (2010), a presença de observadores em um determinado país, aumenta a probabilidade de que ele siga normas e convenções internacionais de democracia, fazendo, inclusive, com que os relatórios das MOEs influenciem o tipo de sanção que será aplicada, caso ocorram violações muito graves a normas democráticas, nos processos eleitorais. Da mesma forma, aumenta a possibilidade de que sanções sejam aplicadas aos Estados que violam tais normas, por exemplo, ao não realizarem eleições, uma vez que compartilham dos mesmos valores democráticos (idem).

Para a autora, imposição de custos materiais, políticos e aqueles que interferem na imagem internacional do país, são algumas das sanções que podem ser aplicadas. No entanto, como saber quando violações ocorreram? A resposta reside na atuação dos observadores, que, através da publicação e divulgação de seus relatórios fornecem subsídios, de um lado, para que membros relutantes em cumprir normas democráticas acabem por ceder à sua aplicação e, de outro, para a comunidade externa em geral, pois permite a avaliação de forma coordenada sobre qual a melhor resposta (sanção) aplicar em cada caso (ibidem) ${ }^{42}$. A maior violação às normas democráticas é a existência de fraude, em um determinado processo de escolha.

De forma mais específica, Anglin (1998) identifica ao menos oito funções das missões de observação internacional, mostrando que o papel realizado pelos observadores se tornou mais ativo a partir da Terceira Onda. Em primeiro lugar, tem-se a construção de confiança, que consiste na amenização de tensões entre partidos políticos e eleitores, melhorando a integridade do processo eleitoral. Essa função é apoiada por McCoy, Pastor e Garbar (1991) e contestada por Carothers (1997). Em seguida, contribuem para a prevenção de conflitos, uma vez que a presença de observadores (nesse caso incluídos os observadores domésticos também) tende a minimizar a possibilidade de coerção ou fraude. Tal inferência foi confirmada, através de pesquisa experimental, por

\footnotetext{
42 A lógica por trás do experimento da autora é o mesmo daquele de negociações de comércio internacionais e outras, em que alguns requisitos mínimos são necessários para que as conversas avancem, a exemplo do comprometimento das partes em cumprir com acordos estipulados.
} 
Hyde (2007). Uma terceira função corresponde à resolução de disputas, quando os observadores estão em uma posição de mediação de disputas locais, eles podem tentar persuadir os candidatos em disputa a participar do processo eleitoral, mais que recorrer à violência ${ }^{43}$. Um exemplo é o caso peruano com o autogolpe de Fujimori, no início dos anos 1990, quando os observadores condenaram as eleições considerando-as fraudulentas e, meses depois, passaram a mediar o diálogo entre as principais lideranças do país que concorreram nas eleições seguintes. Quarto, a própria observação de aspectos relevantes do pleito, como o funcionamento da comissão nacional eleitoral, o andamento das campanhas e a contagem de votos. Quinto, a transmissão de informações, prática que consiste na divulgação daquilo que foi observado ao longo do período em que os observadores estiveram no país. Sexto, a verificação ou validação de todo o processo eleitoral, que em geral, é comunicada pelo presidente da missão. Sétimo, aconselhamento sobre melhores práticas, com vistas ao aperfeiçoamento de todo o processo. A prática de aconselhamento foi mais plenamente desenvolvida por organizações como a Commonwealth e a OSCE, com maior atuação na Europa e, depois, por organizações americanas, a exemplo da OEA. Oitavo, a certificação de que um processo foi livre e justo (idem; Sebudubudu, 2011).

Sobre o último ponto cabe mencionar que a tipificação de um processo eleitoral como livre e justo tem sido realizado, na maioria das vezes, por organizações de monitoramento internacionais com menor experiência. Organizações que já possuem longa tradição na tarefa tendem a evitar essa categorização devido à dificuldade em definir o que seriam eleições livres e justas, preferindo emitir notas nas quais atestam que o processo eleitoral cumpriu com os requisitos necessários com normas ou padrões democráticos internacionais.

Se comparada à primeiras missões, a observação passou atualmente a abranger mais tarefas. Estas se tornaram mais sofisticadas e seu escopo também mudou. O papel dos meios de comunicação, dos partidos políticos e dos

\footnotetext{
43 Um exemplo é o caso peruano com o autogolpe de Fujimori, no início dos anos 1990, quando os observadores condenaram as eleições considerando-as fraudulentas e, meses depois, passaram a mediar o diálogo entre as principais lideranças do país que concorreram nas eleições seguintes.
} 
organismos eleitorais passaram a ser mais cautelosamente monitorados e de forma mais sistêmica. As listas de votação, credenciais dos votantes e registros eleitorais cresceram em importância, sob os olhos dos observadores, tendo o mesmo acontecido às leis eleitorais e regras de campanha.

Conforme Nevitte e Canton (1997, p. 48):

\begin{abstract}
"Assim como no passado, a presença de observadores nas mesas de voto continua a ser a peça central da maioria dos esforços de observação. Mas tem havido mudanças significativas na forma como observadores são distribuídos, nas tarefas que têm a desempenhar, no que eles relatam, e na forma como seus relatórios são analisados. Essas mudanças refletem tanto uma maior valorização da importância do contexto (ambiente) na qual uma competição eleitoral acontece quanto uma compreensão mais aguçada da necessidade de uma avaliação mais sistemática da qualidade do processo eleitoral. 0 estabelecimento de parâmetros melhorou a capacidade dos observadores de avaliar uma série de atividades do dia das eleições, incluindo a abertura e fechamento das mesas de voto, o desempenho de seus funcionários e agentes de partidos, procedimentos para garantir a inviolabilidade das urnas, protocolos de identificação dos eleitores, o gerenciamento de eleitores não registrados e a contagem e divulgação dos votos. Maior precisão na documentação de violações e o desenvolvimento de indicadores mais sensíveis para avaliar o clima eleitoral foram acompanhadas por melhorias nas ferramentas quantitativas disponíveis para monitores. Tabulações de voto paralelas (PVT), ou 'contagem rápida', tornaram-se mais eficientes e precisas, como resultados de procedimentos estatísticos e de amostragem aprimorados, tecnologias mais avançadas, melhorias na formação de observadores, e refinamentos na abordagem analítica. Tais procedimentos são rotina atualmente".
\end{abstract}

Para Hartlyn e McCoy (2006) essa mudança aconteceu por conta, primeiro, da necessidade de dificultar qualquer tipo de fraude por parte de líderes autoritários, forçando-os a tornar suas práticas mais sofisticadas, caso desejassem influenciar o resultado das eleições. Depois, em função da resistência ou reemergência de regimes patrimonialistas, em que muitos governantes buscam aumentar sua permanência no poder através de meios questionáveis. Em outras palavras, líderes de regimes não democráticos através de eleições democráticas que tentam, através de manipulação eleitoral, estender seus mandatos.

Nesse sentido, a observação internacional possui algumas vantagens com relação à observação doméstica. Conforme Lansford (2011b), a observação doméstica teve sua formalização em meados do século XX quando organizações não-governamentais e grupos religiosos observaram eleições no Sul dos Estados Unidos e, depois, em outros países. Esta é realizada por redes de 
grupos locais de cidadãos ou ativistas de direitos humanos ${ }^{44}$. Embora promovam maior transparência do processo, tendem a ser vistos com desconfiança pelos eleitores devido a dúvidas quanto à sua imparcialidade (Sebudubudu, 2011).

Já a observação internacional, leva maior integridade ao processo, pois aumenta a confiança dos eleitores, quanto maior for o reconhecimento e importância da organização que os envia e, também, devido a sua credibilidade como portadores de valores de governança democrática internacionais (idem) ${ }^{45}$.

No entanto, Donno (2010) argumenta que os efeitos gerados pela observação internacional variam conforme a importância geopolítica dos países, porque "em países mais fracos geopoliticamente, a publicidade gerada pelos observadores internacionais é relativamente menos importante, simplesmente pelo fato de que a ingerência, nesses países, é menos controversa" (p. 603). De forma semelhante, eleições fundacionais ou aquelas que são realizadas após longos períodos de conflitos, como guerras civis, em geral são menos criticadas, ao passo que eleições em países recebedores de grandes volumes de financiamento internacional são fortemente monitoradas (idem; McCoy, 1998; Hartlyn e McCoy, 2006).

Embora os observadores internacionais tentem ao máximo julgar as eleições conforme critérios de governança boa governança eleitoral, nem sempre essa tarefa é possível,segundo Elklit e Svensson (1997), os observadores acabam por basear suas conclusões por meio de uma abordagem mais individualizada. Assim, muitas vezes são levados em consideração fatores como o nível de desenvolvimento, capacidade do Estado e história de democratização. Mesmo eleições que não se enquadram em algumas das normas referidas, tendem a ser consideradas legítimas, se de fato expressaram a vontade popular respeitando leis e regulamentos eleitorais (idem) ${ }^{46}$. Essas sãoalgumas das limitações da observação. Existem outras.

Chand (1997) chama a atenção para a possibilidade de que, por vezes, os observadores possam legitimar uma fraude. Isto é algo intrínseco à tarefa de

\footnotetext{
44 Para uma lista de organizações e redes criadas com o intuito de realizar o monitoramento doméstico de eleições, a partir dos anos 1980, ver: Lean, 2007 e Nevitte e Canton, 1997.

45 Para uma maior discussão das diferenças entre observadores domésticos e internacionais, ver: Nevitte e Canton, 1997.

46 São os chamados "gray zone regimes", ou, regimes que se encontram no limite entre uma democracia eleitoral e uma autocracia eleitoral (Carothers, 2002; Hartlyn e McCoy, 2006 e Hartlyn, McCoy e Mustillo, 2008).
} 
observação, e pode ocorrer tanto com os visitantes internacionais, quanto com as organizações em rede de observação domésticas. "Isso pode ocorrer se os observadores falharem na tarefa de detecção da fraude, declarando uma eleição como 'livre', ou de forma maliciosa, ignorar evidências de fraude" (p. 557).

Carothers (1997) também destaca que os observadores não podem forçar a resolução de conflitos domésticos, ou mesmo, garantir que a comunidade internacional possa aplicar algum tipo de sanção quando evidências de más práticas eleitorais surgirem. Outro problema que ele indica é a ênfase da observação internacional no dia da eleição, argumentando que, muitas vezes problemas emergem já na corrida eleitoral, ou até mesmo, meses antes disso.

O autor critica, ainda, o boom no número de organizações ${ }^{47}$ que passaram a se dedicar à observação nos últimos anos, ao afirmar que muitas delas têm observadores curiosos e mal preparados, "embaraçosamente pouco profissionais e paternalistas" (p. 22). Da mesma forma, "eles fazem declarações pós-eleitorais precipitadas que desviam a atenção de relatórios mais importantes emitidos por organizações com mais experiência e maior presença" (idem).

No entanto, para Kelley (2009) ainda que exista essa competitividade entre diferentes organizações, a multiplicidade de observadores favorece sua influência sobre o meio doméstico, "porque o consenso entre elas pode potencializar sua legitimidade individual, bem como a legitimidade das normas internacionais que enfatizam" (p. 63).

Em 2005, com vistas a melhorar a atuação e direcionamento das ações dos observadores em missão, as Nações Unidas promoveram uma assembleia na qual foi adotada a Declaração de Princípios para a Observação Internacional Eleitoral (DPIOE) e o Código de Conduta para Observadores Eleitorais Internacionais. A Declaração teve como base a Declaração Universal dos Direitos Humanos, de 1948, o Pacto Internacional sobre os Direitos Civis e Políticos (ICCPR), de 1968 e outros instrumentos internacionais universais e regionais ${ }^{48}$. Entre seus principais pontos constam o direito de todo cidadão à participação nos assuntos públicos de seu país, sendo este direito exercido, entre outros meios, pela livre escolha de seus representantes (DPIOE, 2005).

47 Ver também a esse respeito: Daxecker e Schneider, 2014.
${ }^{8}$ Cf. Quadro 2. 
$\mathrm{Na}$ mesma ocasião, as organizações internacionais e intergovernamentais, assinam o Código de Conduta para Observadores Eleitorais Internacionais, que traz, entre outras diretrizes: (1) respeito pela soberania e normas de direitos humanos universais; (2) respeito das leis do país e dos órgãos eleitorais; (3) respeito pela integridade das missões; (4) imparcialidade; (5) não obstrução do processo eleitoral em observação etc.

À época já eram mais de vinte organizações especializadas no tema, de todas as regiões, e que assinaram a declaração. Esse número segue maior a cada dia. E muitas das organizações seguem esses princípios, além de suas próprias diretrizes. Hartlyn e McCoy (2006) enfatizam que, na verdade, o maior desafio aos observadores não se encontra na coordenação internacional de todas as organizações, mas antes, reside em sua própria atuação. Para os autores, os observadores têm como maior desafio, assim como os partidos políticos, "determinar até que ponto irregularidades resultaram de falta de competência, de recursos ou treinamento, mais que uma tentativa de fraude eleitoral, ao mesmo tempo em que devem identificar se a fraude foi localizada e esporádica, e não centralizada" (p. 47).

Para além do desafio da coordenação das práticas de cada uma das organizações de observação, há ainda uma discussão sobre o que deve ser ou não observado e por quanto tempo. Assim, as autoras defendem duas perspectivas. De um lado há a observação que acontece somente no dia da votação - que é realizada principalmente por organizações de monitoramento mais com menor tempo de existência -, deixa de lado um número maior de fatores a serem observados antes, durante e depois da eleição. Como consequência, suas observações são menores na habilidade em julgar todo o processo. Por outro lado, a observação que leve em conta todo o processo eleitoral é capaz de emitir conclusões mais certeiras sobre sua qualidade. Esta é a visão de muitas das organizações internacionais de monitoramento eleitoral com maior tradição (idem).

O Centro Carter desenvolveu um programa de promoção da democracia, na qual está incluído o Projeto de Padrões de Eleições Democráticas (DES), criado em 2003. Em sua primeira fase, colaborou junto às Nações Unidas para a criação da Declaração de Princípios para a Observação Internacional Eleitoral (DPIOE) e o Código de Conduta para Observadores Eleitorais Internacionais, 
aprovadas em 2005. No ano seguinte, o Centro Carter se empenhou na preparação de uma série de instrumentos voltados à atuação dos observadores, como manuais e bancos de dados relativos à observação internacional de eleições. A partir de 2011, o Projeto trabalhou para divulgação dessas ferramentas junto aos governos e órgãos eleitorais dos países. E, finalmente, em 2015 concentrou seus esforços em fazer avançar os padrões eleitorais, assim como aumentar o compartilhamento de conhecimento sobre integridade das eleições, observação internacional e promoção da democracia (Centro Carter, 2016).

No mesmo caminho, a OEA promoveu e desenvolveu uma norma de padrão eleitoral, com base na ISO 900149. A ISO/TS 17582 ou padrão eleitoral ISO foi criada pela OEA em conjunto com especialistas da área eleitoral e aprovada na Organização Internacional para Padronização (ISO), em 15 de fevereiro de 2014. É uma norma internacional de gestão de sistemas eleitorais, que fornece um guia completo para a avaliação da qualidade de uma eleição aos membros de organismos eleitorais, através de um modelo de gestão eficaz dos processos eleitorais (ISO/TS 17582, 2014).

Para se adequar a norma as organizações eleitorais devem demonstrar sua capacidade de gerir uma eleição por voto secreto, fornecendo resultados confiáveis, transparentes, livres e justos, que atendam aos requisitos eleitorais, antes, durante e após o dia da votação (em todo o ciclo eleitoral). A norma ISO/TS 17852 tem como objetivo aumentar a confiança dos cidadãos, candidatos, organizações políticas e outras partes interessadas nos processos eleitorais através da implementação eficaz de um sistema de gestão da qualidade eleitoral, aí incluídas, recomendações para melhorias contínuas. Por meio da norma, os organismos eleitorais podem demonstrar seu compromisso com uma série de normas democráticas internacionais, além de garantir maior integridade ao processo eleitoral (idem).

O papel da observação internacional no âmbito da norma prescrita consiste "na construção de accountability internacional através do qual os governantes recebem um 'selo de qualidade' que os legitima” (Carothers, 1997).

\footnotetext{
49 A ISO 9001 é um conjunto de normas de padronização emitida para um determinado serviço ou produto. Ela tem como objetivo melhorar a gestão de uma empresa, podendo ser aplicada em conjunto com outras normas de funcionamento.
} 
Não obstante os esforços para normatização de práticas eleitorais, a OEA tem voltado sua atuação na área eleitoral para a maior institucionalização das missões de observação eleitoral internacionais. Em 2001, houve a aprovação da Carta Democrática Interamericana, que "foi reflexo do consenso regional sobre a necessidade de se alcançar um maior desenvolvimento social, político e econômico dotando as MOEls de valor fundamental no centro da democracia eleitoral, único sistema político válido para a região" (OAS, p. 5, 2012). Em outras palavras, correspondeu ao desejo dos governantes da região de manter a tradição de uma cultura política eleitoral democrática, fundada no Estado de Direito, que perdurou, inclusive, durante os períodos autoritários e, que, atualmente, se encontra ratificada em instrumentos internacionais, a exemplo da Carta.

Conforme Carrillo (2007, p. 89),

\begin{abstract}
“... agora não somente trabalham na área muitos atores, como também ocorreu uma mudança de enfoque. Passou-se de uma busca de confiança para uma busca de efetividade. Agora há uma ampla variedade temática na qual os distintos integrantes do sistema institucional trabalham com vistas ao fortalecimento da democracia eleitoral".
\end{abstract}

A experiência acumulada na organização de eleições e a cooperação internacional nestes temas, aí incluídas as missões de observação eleitoral internacionais, levaram a maior identificação de temas prioritário à democracia eleitoral. Nesse sentido, não somente a OEA, mas outras organizações internacionais de monitoramento têm voltado seus esforços para a o desenho de novos sistemas eleitorais, com a valorização do acesso dos meios de comunicação às informações sobre os processos eleitorais, da participação de mulheres (através das cotas de gênero) ${ }^{50}$, dos grupos indígenas, dos recursos disponíveis àqueles eleitores com necessidades especiais, do voto eletrônico e do cuidado com materiais sensíveis (OAS, 2012).

É com esse escopo que tem início as missões de observação da União de Nações Sul-Americanas (Unasul). Apesar de não ter assinado a Declaração

\footnotetext{
${ }^{50}$ As Nações Unidas também compartilham dessa visão, visto que para a Organização somente um governo inclusivo, que promova a igualitária participação de homens e mulheres nos processos decisórios, será capaz de fortalecer a democracia e promover seu correto funcionamento. Esse princípio aparece me diversos documentos como: Plataforma de Ação de Beijing (1995), Convenção para Eliminação de Todas as Formas de Discriminação contra Mulheres (1979), Declaração Universal dos Direitos Humanos (1948), entre outros.
} 
das Nações Unidas sobre observação internacional de eleições, a Organização enviou sua primeira missão para acompanhar a eleição presidencial da Venezuela, em 2012. A experiência foi importante porque demonstrou uma diferença entre sua atuação e daquelas de outras organizações da região. A União envia observadores com o intuito de acompanhar os processos eleitorais, mas não os observar, ou seja, os governos solicitam uma missão à Unasul, mas não esperam que os observadores avaliem o ambiente político que precede $o$ dia da votação ou a própria condução da eleição para depois divulga-las publicamente. Esperam, isso sim, que observações sejam feitas sobre o dia da eleição e que depois, sejam encaminhadas ao próprio organismo eleitoral do país, na forma de recomendações.

Por fim, esse é o estado da arte da observação atualmente. No próximo tópico será apresentada a questão relativa à soberania dos país, frente à presença de um ator internacional em seus processos de escolha popular, além de outros entraves às MOEls.

\subsubsection{A questão da soberania e os entraves postos às missões internacionais de observação eleitoral}

De forma inicial, se faz importante diferenciar a observação do acompanhamento eleitoral. Segundo Bjornlund (2004), o propósito da observação seria o de construir confiança nacional e internacional sobre a integridade das eleições, ou documentar e expor a forma através da qual o processo ocorreu, se foi como o esperado ou não, ao passo que 0 acompanhamento, trataria somente do testemunho da votação, após um convite dos países que realizam o pleito. Neste caso, não haveria quaisquer emissões de relatórios ou divulgação pública de observações sobre as eleições celebradas e, caso houvesse observações, seriam conhecidas e difundidas somente internamente entre os governos e as organizações estrangeiras convidadas (idem; Pastor, 1995).

A tendência do acompanhamento é visível não somente na América Latina, como também em outras regiões. Hyde (2006), chama organizações de acompanhamento de "grupos amigos", que são utilizados por líderes não 
democráticos com a expectativa de que as eleições sejam mais facilmente legitimadas.

Para McCoy, McConnel e McCarthy (2015), o acompanhamento implica apenas em uma presença simbólica por parte dos visitantes estrangeiros, cuja função principal é fortalecer o papel do organismo eleitoral, como um ente comprometido, porém sem nenhum julgamento quanto à qualidade das eleições, tendo como foco, principalmente, os procedimentos relativos ao dia das eleições.

Venezuela e, mais recentemente, Nicarágua, se distanciaram da norma internacional de monitoramento eleitoral, de modo a evitar a observação internacional e optaram, em seu lugar, pelo acompanhamento internacional. Embora o governo desses países tivesse boa relação com a observação, tendo convidado grandes missões internacionais a seus processos eleitorais (quatro eleições presidenciais na Nicarágua entre 1990 e 2006, e seis na Venezuela, entre 1998 e 2006, receberam observadores), os organismos eleitorais operaram uma mudança importante nas eleições seguintes, limitando a função de grupos internacionais, atribuindo-Ihes novo papel de acompanhamento eleitoral (idem).

A partir de 2006, o Conselho Eleitoral da Venezuela (CNE) substituiu a prática da observação internacional pelo acompanhamento internacional. 0 convite à observação foi feito somente a "personalidades relevantes". No mesmo caminho, as eleições presidenciais tiveram como convidados internacionais, quarenta membros da Unasul (McCoy e McCarthy, 2013).

A negativa do governo venezuelano em convidar observadores de organizações como a OEA e o Centro Carter, teve origem no argumento da violação da soberania nacional e, também, na concepção da Chávez sobre o bolivarianismo. Significa dizer que organizações como as citadas "formariam parte de um 'regime ocidental' marcado pelos poderes dominantes, que utilizam tais organizações para dar lições sobre a democracia ao resto do mundo" (McCoy, McConnel e McCarthy, 2015, p. 120). Da mesma forma que países como Estados Unidos e União Europeia não convidavam observadores latinoamericanos a observar suas eleições, eles não poderiam julgar os processos políticos da Venezuela (idem).

Já na Nicarágua, embora a observação internacional tenha contribuído para a transição do país rumo à democracia e tivesse o apoio de grande parte 
da população, a prática deixou de ser bem aceita pelo governo. A resistência à observação teve início a partir das eleições municipais de 2006,

“... nas quais o governo se recusou a convidar observadores
internacionais consolidados ou de realizar o cadastramento de grupos
de observadores nacionais legítimos. Acusações da oposição de atos
generalizados de fraude corromperam as eleições, e países doadores
europeus e Estados Unidos impuseram como condição para sua ajuda,
melhorias no processo eleitoral. " (ibidem, p. 115).

A resposta do presidente Ortega foi o de institucionalizar novas condições para a observação eleitoral, tal como: a restrição dos locais que seriam observados internacionalmente, que passariam a ser determinados pelo organismo eleitoral. Em 2011, o Conselho Supremo Eleitoral (CSE), passou a de fato utilizar o termo acompanhamento, ao invés de observação, ao se referir aos visitantes estrangeiros. O presidente Ortega vinculou a observação eleitoral à intervenção exterior e, mais especificamente, ao histórico intervencionista dos Estados Unidos (McConnell, 2013).

Ao final do processo eleitoral de 2006, o governo nicaraguense negociou de forma individual com cada uma das organizações de acompanhamento o reconhecimento das eleições, ao mesmo tempo em que cumpria minimamente normas internacionais de boa governança eleitoral de modo a evitar censura externa.

Se, de um lado, tem-se Venezuela e Nicarágua como países que desafiam a crescente norma de observação, por outro lado, há países que já a adotaram há tempos. O modelo de monitoramento internacional de eleições, tal como ele existe atualmente, teve seu desenvolvimento atrelado à emergência de normas internacionais democráticas, sobretudo, em países latino-americanos (Hyde, 2006, 2011; Santa-Cruz, 2007; 2013).

Mais especificamente, a norma de monitoramento internacional se espalhou, inicialmente nos países latino-americanos, para depois, chegar aos ex-territórios da União Soviética, e além. Hyde (2011) argumenta que após a primeira observação em um país soberano, nomeadamente, a Costa Rica, em 1962, outros países passaram a mimetizar o mesmo comportamento. Ou seja, a observação passou a ser prática mais comum, uma vez que, mesmo líderes autoritários viram benefícios interessantes no convite à presença de estrangeiros em seus processos eleitorais. "Quando os promotores da democracia reconheceram no monitoramento internacional um sinal de que um governo 
estava comprometido com a democracia, outros líderes também tiveram 0 incentivo para convidar monitores eleitorais" (idem, p. 91).

Da mesma forma, à medida que o monitoramento se tornou uma norma internacional, os países que passaram a realizar eleições, sem a presença de observadores, passaram a ser vistos como não democráticos (Kelley, 2008; Bjornlund, 2004). Essa é uma tendência que se acentuou a partir dos anos 2000 e que tem levado, inclusive, democracias consolidadas, a exemplo dos Estados Unidos e da Áustria, a ter observação em seus processos internos.

Em contrapartida, caso não existisse a expectativa de que um Estado seria beneficiado de diversas formas, ao convidar monitores externos, tal norma não teria se tornado tão forte, nos últimos anos. "A decisão de convidar observadores internacionais é condicionada pela percepção de líderes de que há algum tipo de benefício externo atrelado à democracia" (ibidem, p. 106). Entre eles estão: assistência democrática direta; recursos derivados de acordos bilaterais e multilaterais; condicionalidade para participação em alguma organização internacional etc.

Mesmo democracias consolidadas passaram a chamar observadores a seus processos eleitorais, de modo a demonstrar seu compromisso com normas internacionais de democracia. Ao informar qualquer tipo de comportamento inadequado no processo eleitoral, através de conferências de imprensa e relatórios, por exemplo, os observadores internacionais pressionam os governos a colaborar com a aplicação de normas democráticas relativas à boa governança eleitoral (Donno, 2010).

No caso latino-americano, nas chamadas democracias eleitorais, muitos líderes tendem a manter seu poder, aparentemente obedecendo à norma de monitoramento internacional de eleições, por meio de: diferentes formas de manipulação, que não são facilmente detectáveis pelos observadores; fazendo convites à nações amigas ou missões com pouca experiência na área, garantindo que os visitantes irão, de fato atestar as eleições como válidas e, caso eles sejam descobertos, promovem uma verdadeira campanha para desacreditar os relatórios das missões convidadas (Hyde, 2006).

Hyde (2006; 2011) argumenta que uma consequência indesejada da observação internacional foi o surgimento de técnicas mais sofisticadas de manipulação eleitoral. Calingaert (2006, p. 138), concorda com a autora e diz 
que "a crescente sofisticação de fraudes eleitorais e manipulação tem correlação com melhorias nas habilidades e métodos empregados pelos observadores eleitorais". O mesmo argumento é defendido por Carothers (1997).

\subsubsection{O papel dos observadores internacionais nos sufrágios atuais: da prática à especialização}

Goodwin-Gill (2006) define o papel dos observadores com relação às normas. Para ele, não há como uma norma ser aplicada por si só, de modo que o papel dos observadores é o de verificar se, realmente, os fatos ocorridos ao longo de um processo de escolha popular ou se as circunstâncias nas quais o processo ocorreu correspondem aos critérios internacionais de boa governança eleitoral.

A ausência de missões estrangeiras ou mesmo a recusa por parte de um governo em receber observadores externos, passou a ser visto internacionalmente como uma mostra de que as eleições não seriam nem livres, nem honestas. "A opinião pública, contudo, passou não somente a aceitar a observação de estrangeiros, como a desejá-la, cada vez mais" (Vasak, 2000, p. 300), por acreditar que somente assim, os direitos dos cidadãos estariam garantidos e protegidos.

Simpser e Donno (2007) reconhecem os benefícios atrelados à observação, porém acreditam que "as missões de monitoramento eleitoral encorajam o aumento das manipulações pré-eleições, tendo efeitos negativos em sua qualidade institucional e governança" (p. 501; Hyde e O'Mahony, 2010). Para os autores, a observação pode ser prejudicial à boa governança eleitoral, na medida em que os incumbentes tendem a recorrer a práticas não convencionais de manipulação eleitoral, a exemplo da repressão aos meios de comunicação e do controle de órgãos administrativos para se manter o poder com a aproximação de um processo eleitoral. Os chamados efeitos secundários seriam consequências indesejadas do monitoramento e derivam da adaptação estratégica dos governos com relação a essa nova norma internacional. Ao direcionar seus esforços para os períodos pré e pós-eleitoral os governos incumbentes tornaram a tarefa de observação mais especializada. 
No entanto, nem todos os governos respondem da mesma forma ao monitoramento internacional. Conforme mencionado anteriormente, a posição geopolítica de um país influencia o impacto que um relatório negativo que condena uma eleição como não livre e injusta poderá gerar na qualidade das instituições e governança (Donno, 2010). O mesmo pode ser dito para a resposta dos governos aos relatórios das MOEls. Segundo Simpser e Donno (2007, p. 511), "os governos variam na sensibilidade aos vereditos dos observadores. Países maiores e mais poderosos, assim como produtores de petróleo e gás, estão mais isolados de críticas internacionais, mais que aqueles pequenos e economicamente dependentes".

O mesmo pode ser dito para as adaptações estratégicas que os governos terão com relação à observação. Em democracias liberais algumas práticas são impensáveis, enquanto em muitos países em desenvolvimento, as mesmas ações poderiam ser colocadas em prática, porque muitas de suas instituições políticas, judiciárias e econômicas são novas ou frágeis (idem, Merloe, 2015).

Assim, embora muitas vezes o monitoramento esteja associado à defesa de uma série de normas internacionais de boa governança democrática, essa premissa nem sempre se faz presente. Segundo os autores, se é verdade que muitas vezes esse relacionamento entre imposição da norma e sua realização ocorre, não é menos verdade que a adaptação dos atores domésticos à norma pode gerar consequências não desejáveis como a manipulação e/ou fraude eleitoral (ibidem).

Isso quer dizer que não necessariamente os governos irão se submeter à norma, o que leva à necessidade de maior acompanhamento por parte das organizações de monitoramento internacional sobre os processos políticos dos países. Muitas vezes a observação acontece não somente em uma, como em várias eleições. Em alguns países em transição de regime, se tornou prática comum o acompanhamento dos processos desde as eleições fundacionais, como uma forma de averiguar se os critérios preconizados pela boa governança eleitoral democrática, foram, de fato, aplicados ao longo dos anos.

Freidenberg (2015) acrescenta que entre as principais más práticas indicadas pelos informes das missões de observação internacionais, entre os anos de 2013 e 2015, em vários países latino-americanos, estão: o transporte coletivo de eleitores até os locais de votação; a violação do segredo de voto; 
candidatos que ganham a eleição mesmo em condição carcerária; violência física contra candidatos; mortes de candidatos e intimidação de jornalistas e/ou de funcionários eleitorais.

Além da identificação das fraudes eleitorais mostrada pela pesquisadora, há ainda a percepção, por parte da população, de que as más práticas são recorrentes em períodos eleitorais na América Latina.

Informe do Latinobarometro, de 2015, na região latino-americana indicou a seguinte percepção dos indivíduos pesquisados:

\section{Tabela 1 - Percepções sobre as últimas eleições realizadas na América Latina, em países selecionados *}

\begin{tabular}{|c|c|c|c|c|c|c|}
\hline País & $\begin{array}{l}\text { Muito } \\
\text { limpas }\end{array}$ & Limpas & $\begin{array}{c}\text { Fraudulenta } \\
\mathbf{s}\end{array}$ & $\begin{array}{c}\text { Muito } \\
\text { fraudulentas }\end{array}$ & $\begin{array}{c}\text { Não } \\
\text { responde } \\
\text { u }\end{array}$ & $\begin{array}{l}\text { Não } \\
\text { sabe }\end{array}$ \\
\hline Argentina & $6,8 \%$ & $50,2 \%$ & $27,30 \%$ & $4,10 \%$ & $0,5 \%$ & $11,1 \%$ \\
\hline Bolívia & $5,2 \%$ & $41,9 \%$ & $33,10 \%$ & $6,40 \%$ & $0,9 \%$ & $12,4 \%$ \\
\hline Brasil & $2,4 \%$ & $28,3 \%$ & $41,80 \%$ & $16,60 \%$ & $0,7 \%$ & $10,2 \%$ \\
\hline Chile & $9,7 \%$ & $57,3 \%$ & $15,10 \%$ & $3,10 \%$ & $2,0 \%$ & $12,9 \%$ \\
\hline Colômbia & $2,4 \%$ & $33,2 \%$ & $42,60 \%$ & $13,40 \%$ & $0,6 \%$ & $7,8 \%$ \\
\hline Costa Rica & $9,3 \%$ & $50,8 \%$ & $26,80 \%$ & $6,40 \%$ & $0,7 \%$ & $6,0 \%$ \\
\hline $\begin{array}{l}\text { República } \\
\text { Dominica }\end{array}$ & $3,8 \%$ & $52,2 \%$ & $32,10 \%$ & $6,70 \%$ & $0,3 \%$ & $5,0 \%$ \\
\hline Equador & $8,8 \%$ & $50,7 \%$ & $24,6 \%$ & $3,8 \%$ & $0,7 \%$ & $11,3 \%$ \\
\hline El Salvador & $3,6 \%$ & $33,9 \%$ & $39,6 \%$ & $10,9 \%$ & $1,0 \%$ & $11,0 \%$ \\
\hline Guatemala & $2,6 \%$ & $29,1 \%$ & $39,7 \%$ & $14,5 \%$ & $0,7 \%$ & $13,4 \%$ \\
\hline Honduras & $3,2 \%$ & $29,4 \%$ & $37,1 \%$ & $17,1 \%$ & $0,4 \%$ & $12,8 \%$ \\
\hline México & $1,7 \%$ & $24,8 \%$ & $43,2 \%$ & $24,2 \%$ & $0,1 \%$ & $6,2 \%$ \\
\hline Nicarágua & $4,8 \%$ & $43,2 \%$ & $26,6 \%$ & $9,6 \%$ & $1,6 \%$ & $14,2 \%$ \\
\hline Panamá & $5,9 \%$ & $39,7 \%$ & $36,6 \%$ & $14,4 \%$ & $0,9 \%$ & $2,5 \%$ \\
\hline Paraguai & $1,5 \%$ & $33,30 \%$ & $40,4 \%$ & $13,6 \%$ & $0,4 \%$ & $10,8 \%$ \\
\hline Peru & $4,0 \%$ & $45,80 \%$ & $30,1 \%$ & $6,6 \%$ & $1,8 \%$ & $11,8 \%$ \\
\hline Uruguai & $18,4 \%$ & $63,20 \%$ & $11,2 \%$ & $1,0 \%$ & $0,9 \%$ & $5,2 \%$ \\
\hline Venezuela & $10,8 \%$ & $26,2 \%$ & $27,5 \%$ & $25,7 \%$ & $1,2 \%$ & $8,5 \%$ \\
\hline Total da região** & $5,9 \%$ & $40,8 \%$ & $31,8 \%$ & $11,0 \%$ & $0,9 \%$ & $9,7 \%$ \\
\hline
\end{tabular}

${ }^{*}$ Nota: Pergunta: "Você crê, de maneira geral, que as últimas eleições presidenciais neste país foram muito limpas, limpas, fraudulentas ou muito fraudulentas?" ** Nota: A amostra total contou com um total de 20.250 questionários distribuídos na ordem de 1.000 a 1.250, para cada país estudado.

Fonte: Latinobarometro (2015).

Hyde e Marinov (2012) enfatizam que em países nos quais a democracia ainda não se encontra plenamente consolidada, a exemplo das democracias 
eleitorais, atores que aumentem a credibilidade das informações sobre um processo eleitoral, como os observadores, contribuem para que os governos realizem eleições conforme padrões democráticos. Isso se deve ao fato de que muitos governos recebem incentivos para isso - especialmente na forma de financiamentos ao desenvolvimento democrático -, além de ganhar reconhecimento, o que não aconteceria caso fraudassem as eleições, que provavelmente, resultariam em violência e protesto.

Sobre a possibilidade de um grupo de observadores não conseguir identificar uma eleição fraudulenta, legitimando um autocrata eleitoral, Hyde (2012) argumenta que esta é uma questão menor do que indagar se "caso a observação eleitoral não existisse, autocratas seriam vistos, provavelmente, da mesma forma como ganhadores legítimos das eleições" (idem, p. 2). Isso quer dizer que, em um mundo contrafactual sem observadores, menos governos seriam incentivados a realizar eleições limpas.

Destarte, as deficiências na observação que incluem ainda, turismo eleitoral, que é a participação de representantes de organismos eleitorais em missões, mais à passeio, que propriamente tendo interesse pelo processo e divulgação de relatórios de forma prematura, sem o devido acompanhamento do desenrolar do processo eleitoral. A prática de observação incorporou em seu trabalho estratégias mais eficientes na identificação de irregularidades nos processos eleitorais do qual participam. Entre os novos métodos empregados para evitar a manipulação, por exemplo, no período pré-eleitoral está o envio de observadores que chegam ao país meses antes do dia da eleição, os chamados observadores de longa duração (LTOs).

\footnotetext{
"Com início nos anos 1990 e tendo se espalhado em 1995, os LTOs são distribuídos por todo o país com meses de antecedência de uma eleição e relatam todos os aspectos do processo eleitoral incluindo o registro de candidatos e eleitores, campanhas e o estado dos recursos administrativos preparatórios para as eleições, em todo o país" (Hyde, 2006, p. 166).
}

Além desses, também se tornaram métodos comuns a contagem e tabulação paralela de votos, além do monitoramento dos meios de comunicação. Em geral, essas tabulações são realizadas por partidos políticos, no entanto, em casos nos quais não há confiança dos partidos políticos no organismo que 
coordena as eleições e vice-versa, outros grupos locais ou internacionais são necessários para essa tarefa (McCoy, Pastor e Garbar, 1991).

Muitas vezes, os meios de comunicação podem ser utilizados para avaliar se todos os candidatos disputando cargos têm o mesmo acesso à mídia, se há disparidade quanto a cobertura de uma ou outra campanha eleitoral e avaliar a veracidade das informações contidas nas propagandas partidárias (Hyde, 2006).

Em muitos países, a observação internacional se tornou um forte aliado da observação doméstica. Ao contrário desta, a observação internacional é mais difícil de ser desqualificada por líderes autoritários, principalmente, porque sua credibilidade se encontra estabelecida fora do país em que realizam a observação. O trabalho conjunto entre as duas formas de observação tornou-se mais comum, aumentando as chances de que algum tipo de manipulação seja mais plenamente criticada (ibidem, Hyde e Marinov, 2012).

Outro exemplo das mudanças na observação nos últimos anos, além da extensão de seu mandato no período pré-eleitoral, está a maior atenção para com a resolução de disputas pós-eleitorais e aceitação de resultados (McCoy, Pastor e Garbar, 1991).

Segundo Vasak (2000) esse reconhecimento dos observadores internacionais como os representantes de normas internacionais relativas à boa governança eleitoral sugere, assim como já realizado por outras organizações internacionais, a utilização de um emblema comum. Ele acredita que dotar os observadores, independentemente de seus mandatos, de um sinal distintivo apropriado poderia auxiliar na execução de suas missões, resultando em maior coerência e unidade, mesmo entre os diferentes grupos de observadores. Ao que poderia ser acrescentado ainda, resultaria na sua melhor identificação dos observadores, por parte dos órgãos de fiscalização eleitorais, e população em geral.

\subsection{Considerações finais}

Embora o monitoramento de processos eleitorais tenha suas origens no século XIX, é somente a partir das missões multidimensionais das Nações Unidas que ele passara a ser conduzido em países soberanos. Antes, era uma 
prática utilizada mormente pelas Grandes Potências europeias para coordenar as divisões e/ou junções de territórios. Com a ampliação da defesa do princípio de autodeterminação, o monitoramento passou a ser conduzido em colônias que desejavam ser reconhecidas como Estados, no cenário internacional, e, para isso, contavam com a supervisão de observadores.

Já nos territórios soberanos, a observação estava inicialmente condicionada às estratégias de manutenção da paz, no âmbito das Nações Unidas. Com o avanço da Terceira Onda, muitos países buscaram a observação como uma forma de legitimar os governos internacionalmente. Muitas das democracias latino-americanas, surgidas no período, receberam pequenas missões de organizações a exemplo da OEA. Mais recentemente, as missões assumiram tarefas específicas no que tange a questão da identificação de boas práticas eleitorais, ao mesmo tempo em que surgiram novas formas de manipulação eleitoral.

Como se viu, a observação não está isenta de falhas, no entanto, conforme avança em suas técnicas de combate à manipulação eleitoral e, em especial na percepção de fraudes, crescem também as punições àqueles que tentam burla-las. Assim, a cada dia cresce o número de organizações especializadas no tema, assim como sua importância, como um ator de peso no cenário internacional.

Os próximos tópicos irão tratar dos meios empregados pelos observadores em seu trabalho, como forma de identificar se, de fato, os governos têm seguido as recomendações das missões. 


\section{IMPACTO DAS MISSÕES DE MONITORAMENTO INTERNACIONAL NA BOA GOVERNANÇA ELEITORAL DO HAITI E MEXICO: MÉTODOS}

\subsection{Introdução}

Se até 1962 não havia registro de nenhuma eleição monitorada em país soberano, nos últimos anos a situação é bem diferente. É raro um país em desenvolvimento não convidar observadores para seus processos eleitorais.

As expectativas da comunidade internacional mudaram tanto com relação ao comportamento dos Estados, que "observadores internacionais são componentes esperados em todas as eleições legitimadas externamente" (Hyde, 2006 , p. 2). Dessa forma, os observadores internacionais se tornaram atores envolvidos em uma série de processos domésticos ao redor do mundo, porém pouco explorados nas áreas de política internacional e comparada.

Com vistas a contribuir para ampliação dos estudos dessa temática, a tese mostra, agora, o modo, através do qual, será avaliada a atuação dos observadores internacionais, para em seguida, apresentar a metodologia escolhida.

\subsection{O paradigma de transição como norteador da seleção de casos}

Embora um grande número de transições tenha ocorrido durante a Terceira Onda de democratização acelerando seu ritmo a partir dos anos 1990, muitos desses novos governos democráticos não conseguiram se manter. $\mathrm{Na}$ América Latina, as transições ocorreram em países que contavam com altos níveis de inequidade, pobreza, analfabetismo, Estado e sociedade civil fracos, instabilidade institucional etc.

Levitsky e Way (2002) argumentam que essas transições aconteceram, em grande parte, como produtos do ambiente internacional criado pelo pósGuerra Fria, momento no qual: "o triunfo do liberalismo ocidental e o colapso da União Soviética demoliram a legitimidade de outros modelos de regime alternativos, criando fortes incentivos para que Estados periféricos adotassem formalmente as instituições democráticas" (p. 61). 
Foram muitas as formas da influência internacional do período sobre esses países que se democratizavam, a exemplo da condicionalidade, pressão direta de um Estado sobre outro (através de sanções econômicas e internacionais, diplomacia e intervenção militar), passando pelas atividades de atores e instituições em rede. Com base nesse contexto, o modelo liberal democrático ocidental ganhou maior aceitação entre países pós-comunistas e do chamado, à época, de Terceiro Mundo (idem).

Como consequência, os efeitos dessa transição e os custos para mantêla variaram de país para país. Conforme Huntington (1994), os custos variaram conforme o tipo de transição, sendo que, para os casos nos quais havia intenção de um líder autoritário manter seu status, os custos se tornaram cada vez maiores ${ }^{51}$.

Para o autor, passou a existir um ethos democrático, levando a que muitos regimes autoritários enfrentassem problemas de legitimidade. Isso decorreu, sobretudo, do fato de que em regimes autoritários, os líderes faziam muitas promessas para se manter no poder, que, muitas vezes, deixavam de ser cumpridas, ao passo que, os sistemas democráticos "renovam-se através das eleições, tornando possível que uma nova coalizão alcance o poder com novas políticas e novas promessas para o futuro" (idem, p. 57) ${ }^{52}$, além disso, "os sistemas democráticos, têm assim, um âmago institucional comum que estabelece sua identidade. Os regimes autoritários são definidos simplesmente pela ausência deste componente" (ibidem, p.114), porque, muitas vezes, a troca de lideranças nesses regimes, se dá por outros meios, que não as eleições.

Nos regimes autoritários a substituição não é possível, porém, há casos, nos quais os regimes autoritários desenvolveram mecanismos para a substituição regular de seus principais líderes. Esse foi o caso, por exemplo, do México, que até fins dos anos 1980, teve "durante décadas os presidentes mais à direita alternando-se com presidentes mais à esquerda" (p. 57), isso possibilitou que a legitimidade dos governos no país fosse renovada, de forma regular, ainda que de maneira limitada.

\footnotetext{
${ }^{51}$ Caso fossem vistos como autoritários, muitos dos países com líderes autoritários, perderiam benefícios econômicos originários de doadores internacionais apoiadores da democracia, a exemplo do Banco Mundial.

52 Também Schedler (2002a) e Mozaffar (2002) tratam desse ponto ao falar das incertezas processuais que devem existir em um regime democrático para que ele seja legítimo.
} 
Da mesma forma, os regimes que sucederam os regimes autoritários na região, não eram necessariamente democráticos. Conforme Edgell et al (2015, p. 3), "o período pós-Guerra Fria tem sido marcado pela emergência de regimes que imitam procedimentos democráticos sem, no entanto, abraça-los em sua essência".

Segundo Roessler e Howard (2009), os estudos na área passaram, então, a explicar a sequência através da qual os processos democráticos ocorreriam. Porém, à medida que muitos dos "países em transição" pararam de se transformar e se consolidavam a cada dia mais, por meio de categorias estáveis, muitos acadêmicos reconheceram a necessidade de entender esses novos regimes da forma como eles se mostravam, sem tentar encaixá-los em critérios ou padrões previamente existentes.

Assim, passou-se a analisar os novos regimes híbridos (Karl, 1995), que desafiavam definições mais tradicionais de democracias ou regimes autoritários , incorporando elementos de ambos os regimes (Diamond, 2004). Muitas dessas transições democráticas ocorridas entre os anos 1980 e 1990 incluíram maior participação e competição na escolha de novos presidentes, culminando na realização de uma "eleição fundacional". De forma que, a realização de eleições se tornou um dos elementos centrais nos novos regimes (Lindberg, 2009). Isso levou a críticas de muitos autores, que falaram da "falácia do eleitoralismo", ou do erro em se identificar eleições competitivas como uma condição suficiente para definição de uma nova democracia (Karl, 1990; Schmitter e Karl, 1991). Como consequência, os estudos comparativos dialogaram com uma série de conceitos que tentaram caracterizar os novos regimes, que passaram a ser estudados conforme uma definição mínima, na qual as eleições detinham papel central (Castro Santos, 2001).

Porém, Levitsky e Way (2010) deram novo rumo à discussão ao afirmar que "eleições e mesmo eleições competitivas são componentes que definem não apenas democracias, mas também formas mais novas e emergentes de autoritarismo". Para Edgell et al (2015), essa simulação de democracia pelos regimes autoritários representaria não um sinal de democratização, mas antes, uma forma de adaptação que tem feito o autoritarismo mais durável em uma era de grande entusiasmo democrático. 
Carothers (2002) afirma que essa constatação teria contribuído para o "fim do paradigma de transição democrática". Ele diz que dos quase cem países que eram considerados transicionais nos últimos anos, somente uma pequena porção deles obtiveram sucesso no seu caminho rumo à democracia. "Muitos dos 'países transicionais', não são nem ditatoriais, nem claramente democracias. Eles entraram em uma área política cinzenta (grey zone) " (p. 9). O que os identifica é o fato de que eles possuem alguns atributos democráticos, como espaço limitado para participação de partidos de oposição, embora limitado; sociedade civil independente; assim como eleições regulares. Ao mesmo tempo, sofrem de déficits democráticos, a exemplo da baixa participação nas urnas, frequentes abusos de poder e eleições com alto grau de desconfiança quanto ao uso de manipulação e sua legitimidade (idem; Hartlyn e McCoy, 2006 e Hartlyn, McCoy e Mustillo, 2008; Ghandi e Lust-Okar, 2009).

É por isso que Carothers (2002) sugere aos promotores de democracia, que eles levem em conta os padrões políticos de cada país em que intervêm, ao invés de adotar um quadro ideal de democracia que caiba em determinadas formas institucionais. Ele afirma que:

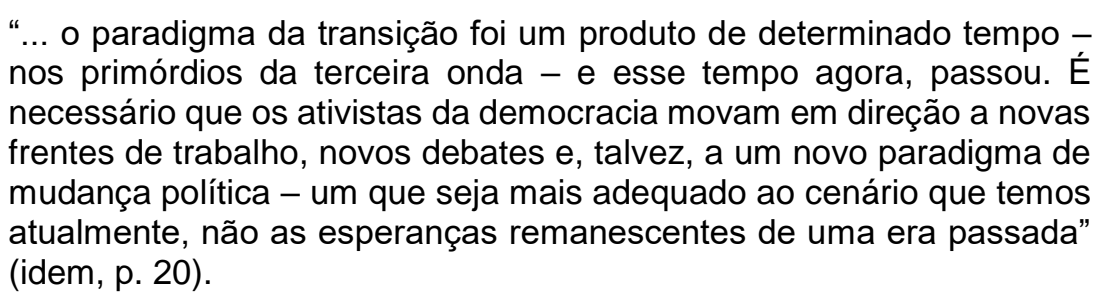

Não obstante o debate sobre o fim do paradigma de transição, Edgell et al (2015) reforçam a importância das instituições democráticas e, mais especificamente das eleições, como um instrumento para o fim do autoritarismo. Os autores fizeram uma pesquisa que englobou as eleições, em uma série de países, entre 1900 e 2012, na qual "encontraram forte evidência de que reiteradas eleições multipartidárias trazem melhorias às qualidades democráticas da política tanto globalmente, quanto nas diferentes regiões" (idem, p. 3). Ou seja, mesmo que líderes autoritários realizem eleições com a expectativa de manter seu próprio poder, o fato de realiza-las, já seria uma contribuição a mais para a democratização, sendo que "as eleições podem não ser, necessariamente o ponto culminante da transição democrática, mas podem ser seu início" (ibidem, p. 7). 
Mesmo Carothers (2002) argumenta que apesar de todos os obstáculos que possam existir nesses novos regimes, isso não significa que as eleições sejam insensatas ou que a comunidade internacional deve parar de pressionar para que elas sejam realizadas conforme padrões e normas internacionais, embora ele sugira que "devem ser reduzidas as expectativas de que as eleições irão gerar mudanças mais profundas" (p. 16).

Haiti e México são assim, regimes híbridos, ou democracias eleitorais, que ainda conservam características de autoritarismo. O primeiro, um país que foi conduzido por muitos anos pela família Duvalier, e que somente em fins dos anos 1980, após a realização de um referendo popular os haitianos conseguiram garantir a escolha de seus representantes pela via eleitoral. Como consequência, o país ainda guarda uma série de práticas políticas herdadas do período anterior, e que não desapareceram com suas tentativas sucessivas de democratização, por meio do voto. Da mesma forma, o Partido Revolucionário Institucional (PRI) teve seus representantes à frente da política mexicana por longos anos, sendo que é somente nos anos 2000 que se inicia sua transição rumo à maior competividade política e alternância de poder, através de conquistas eleitorais significativas. O sistema de partido único mexicano é o de mais longa duração no mundo.

Em, procuramos introduzir a questão das transições e suas nuances enfatizando a importância da eleição dentro do paradigma de transição, contextualizando, assim, os principais espaços nos quais os observadores atuam. A contribuição desses atores está exatamente na premissa de que as boas eleições - como parte do caminho para a construção de instituições políticas mais estáveis, em ambientes diferentes daquele de democracias liberais -, contribuem para a consolidação democrática.

\subsection{Os observadores e as missões}

Segundo Crochetet (2013), a figura do observador eleitoral internacional não é normatizada, de modo que é possível haver em uma mesma missão, observadores com perfis totalmente heterogêneos, "tornando mais difícil identificar a figura do observador, e, portanto, revela os limites de seu poder discricionário" (p. 12). Assim, as missões de observação eleitoral internacionais 
têm em sua composição uma infinidade de atores estrangeiros, sendo que há um painel de observadores com trajetórias sociais e profissionais diferentes (idem). Isso porque, de forma a garantir o máximo de experiências e histórias de vida, a seleção dos observadores, em geral, é feita com base na inclusão do maior número de nacionalidades possível. As missões da OEA enviadas ao Haiti, em dezembro de 2015 e, depois, em janeiro de 2016, tiveram como observadores representantes de quase todos os estados americanos, além de observadores europeus, sobretudo da Espanha e França. Já no México, em junho de 2015, entre os visitantes estrangeiros estavam presentes também muitos observadores de organismos eleitorais da região, além de representantes de organizações internacionais intergovernamentais da África do Sul e China.

Para Crochetet (2013), ainda que o perfil dos observadores seja bastante variado um ponto em comum entre eles é a experiência profissional com o meio internacional. Em busca de determinar a sociogênese dos observadores internacionais, a autora realizou uma série de entrevistas com esses atores, de diferentes nacionalidades, refazendo suas trajetórias profissionais. Assim, entre seus entrevistados havia tradutores, especialistas em mídia e comunicação, segurança, direito etc. Seu estudo demonstrou que, de um lado, não há uma formação específica requisitada aos observadores, ou mesmo, uma trajetória acadêmica e profissional padrão. Por outro lado, a heterogeneidade de trajetórias pessoais e profissionais "permite à cada observador realizar um trabalho particular e acrescentar valor à observação internacional de eleições, que, ao contrário, se nutre da pluralidade e especificidade de competências dos observadores selecionados" (p. 40).

Outra característica importante se refere à capacidade dos observadores de se adaptar à cultura de um país no qual trabalha, além de obedecer a uma série de regras de conduta determinadas pelo Código de Conduta para Observadores Eleitorais Internacionais, de 2005.

Tostensen et al (1997) chamam a atenção para o risco de que entre os observadores possam existir os "turistas eleitorais", ou seja, indivíduos que não levam suas funções como observador muito a sério e consideram a missão de observação como uma oportunidade de visitar outros países. Devido sua atitude pouco profissional, muitos desses turistas podem vir a prejudicar a reputação de 
uma missão, minando sua credibilidade (idem; ACE Project, 2012; Bjornlund, 2004).

Pereira (2006) também analisa o problema do turismo eleitoral, sendo que para essa autora, os turistas tendem a vir muito mais em missões pequenas, de organizações com pouca ou nenhuma tradição em observação internacional. "Muitas organizações enviam pequenos grupos de observadores para monitorar uma eleição, sem, no entanto, fornecer os recursos necessários ou sem que os observadores tenham habilidades mínimas para conduzir um monitoramento de qualidade" (idem, p. 82). Carothers (1997) confirma essa observação, indicando que muitos deles são curiosos que se voluntariam para participar de eleições com grande apelo internacional, em missões pequenas e pouco preparadas, de curto prazo. Esse tipo de observador tende a se comportar de maneira não profissional, quase paternalista, e, geralmente, fazem declarações após o fim do período eleitoral, que são precipitadas e que desviam a atenção de relatórios mais elaborados, de missões maiores.

É por isso, que alguns critérios devem ser seguidos para assegurar a eficiência e confiabilidade das missões, entre eles: período de tempo adequado para que as missões se organizem e realizem uma observação mais completa; recursos suficientes, como sistema de comunicações e transporte; observadores qualificados e treinados e cobertura imparcial, tendo em mente todo o processo eleitoral, de modo a realizar uma análise bem informada; em outras palavras, corresponderia a ver todo o processo eleitoral, e não somente uma parte (dia da eleição) (ACE Project, 2012).

O tipo de atividades monitoradas pelos observadores tende a variar conforme o país em que estão. Kelley (2012b) defende que as organizações são capazes de deter fraudes, aumentar a confiança dos eleitores no processo eleitoral e promover a aplicação de normas democráticas internacionais. Isso, no entanto, só ocorre sob determinadas circunstâncias: "o monitoramento funciona melhor em países que já estão no caminho para a transição, em que já existem pressões domésticas por mudanças..." (p. 7). A qualidade das organizações de monitoramento, contínua a outra, também tem importância. Em eleições nas quais organizações com maior tradição na área estão presentes, registram-se mais críticas do que em eleições que contaram com missões mais recentes. $O$ monitoramento tem apoiado a onda de democratizações da última década, 
sendo que ela tem melhorado as eleições em países que fizeram a transição democrática, assim como tem contribuído para mudar práticas naqueles que são mais relutantes (ibidem).

Assim, foram selecionadas, neste trabalho, as organizações de monitoramento com maior experiência nas eleições latino-americanas. Dessa forma, seguindo Simpser e Donno (2007) e Hyde e Marinov (2014), consideramos tais organizações como aquelas que criticaram eleições no passado, uma vez que organizações mais novas e com menos tradição, tendem a não fazer críticas. Também consideramos na seleção o fato de que organizações mais recentes dificilmente adotaram compromissos formais com a democracia, de modo que seus objetivos muitas vezes não estão explicitamente ligados à ideia da promoção da democracia.

As seguintes organizações entraram foram selecionadas neste trabalho: Organização dos Estados Americanos (OEA); Centro Carter (CC); Instituto Republicano Internacional (IRI); Organização das Nações Unidas (ONU); Fundação Internacional de Sistemas Eleitorais (Ifes); Organização Internacional da Francofonia (OIF); Parlamento Europeu (PE); Comunidade do Caribe (Caricom); Instituto Democrático Nacional (NDI), União Europeia (UE).

De modo a caracterizar as organizações internacionais comprometidas com a promoção da democracia são apresentadas a seguir aquelas de maior peso para a observação internacional eleitoral, nos últimos anos.

\subsubsection{União Europeia}

O fim da Guerra Fria revigorou as relações exteriores da União Europeia. Sua política externa passou a estar centrada na promoção da democracia e dos direitos humanos. Em 1991, a União decidiu que democracia passaria a ser condição para a ajuda externa, tendo sua visão de mundo passado a forcar-se mais na estabilidade entre as nações, do que propriamente, em sua segurança.

Também faz parte desse quadro, o papel mais abrangente desempenhado pelas organizações internacionais, o que, aliado à existência de recursos para suas ações, contribuíram para que mais instrumentos de 
condicionalidade e monitoramento fossem utilizados pela União Europeia, em nome da boa governança e democracia (Magen e Morlino, 2008).

Muitas das transições ocasionadas com o fim da Guerra Fria e da União Soviética não levaram à uma rápida ou mesmo suave transição para a democracia liberal, nos países da região. A partir dos anos 1990, alguns movimentos populares nos países bálticos, Hungria, Polônia, Eslovênia e outros, se traduziram em vitórias eleitorais na rápida consolidação da democracia liberal. No entanto, essas foram as exceções e não a regra. Bulgária, Croácia, Romênia e Tchecoslováquia falharam na tentativa de consolidar uma democracia liberal, logo após o fim do comunismo. Como consequência, a União Europeia passou a concentrar esforços para levar esses países ao caminho democrático (McFaul, 2005).

Magen, Risse e McFaul (2009) argumentam que grande parte dos políticos europeus fez pressão sobre seus respectivos governos, para que fosse criado um mercado de democracias nos antigos territórios da ex-União Soviética.

Porém, como promover essas transições? Whitehead (2004) diz que entre as estratégias utilizadas pela EU, estava a manipulação de incentivos materiais, sobretudo econômicos, para que os países se qualificassem como democracias. Risse (2000) acrescenta que os incentivos não foram somente materiais, mas também, fruto da internacionalização de práticas democráticas, introduzidas por atores externos através de interação social, como uma forma de persuasão normativa.

Assim, inicialmente, o bloco passou a fornecer observação eleitoral, e, de forma complementar a assistência eleitoral. A primeira observação teve palco nas eleições gerais fundacionais da Rússia, após o colapso da União Soviética, em dezembro de 1993. Além da promoção da democracia, através do fortalecimento de instituições, criação de confiança pública sobre os processos eleitorais, identificação de fraudes, intimidação e violência, as missões da UE visam também objetivos de política externa, especificamente construção de paz e manutenção da paz, nos países que a solicitam.

A organização realiza missões em várias partes do mundo e não tem limitação geográfica, sendo o critério para aceite de um convite, principalmente, a observação de eleições presidenciais ou parlamentares em países que fazem parte de uma iniciativa de paz pós-conflito, ou são considerados particularmente 
importantes para o seu desenvolvimento democrático. No entanto, a área na qual a UE tem mais influência é o Centro e Leste europeus sobretudo porque lá, a imposição da condicionalidade democrática compactua com interesses próprios do bloco (Donno, 2013b).

\subsubsection{Organização das Nações Unidas}

O fim da Guerra Fria viu renascer o papel das Nações Unidas como mantenedora da paz e segurança mundiais. Com o estabelecimento da Divisão de Assistência Eleitoral, em 1992, a organização internacional viu crescer o número de pedidos para assistência eleitoral, mais que observação internacional, para construção de instituições democráticas sólidas.

Assim como a União Europeia, a ONU vê a promoção da democracia como um meio para se alcançar a paz e desenvolvimento. E, segundo SantaCruz (2005), em início dos anos 1990, a organização internacional ainda estava muito relutante sobre a realização ou não da observação em países soberanos, porque "ela não desejava estabelecer o precedente de intervir no que ainda era considerada uma questão puramente interna" (p. 684). Embora tenha aceitado enviar uma missão para as eleições da Nicarágua, em 1990, poucos meses depois ela negou o pedido de observação das primeiras eleições, após o fim do comunismo, na Romênia, demonstrando seu mal-estar com a emergência da Norma de Monitoramento Internacional Eleitoral (IEM) (idem).

Nos anos seguintes, a Organização passou a realizar observação no âmbito de suas operações de construção da paz, em especial em El Salvador, Guatemala e Haiti, como parte da estratégia de salvaguarda da paz, após longo período de conflitos internos nesses países. "Eleições democráticas - não somente a assinatura de um acordo de paz - passaram a ser vistas como essenciais na transição da guerra para a paz" (Donno, 2013b).

É no Terceiro Mundo que as regras e proibições relativas à intervenção se relativizaram, tendo o conceito de soberania se redefinido e passado a englobar a proteção dos direitos humanos (Santa-Cruz, 2005; 2013) ${ }^{53}$. Segundo

$53 \mathrm{Em}$ debates sobre a necessidade de observação eleitoral internacional, seus defensores defendiam que que eleições genuínas e periódicas, tais como aquelas verificadas por observadores estrangeiros, eram cruciais aos direitos humanos e democráticos. Em contraste, 
Mathews (1997), no começo dos anos 1990, as Nações Unidas responderam a uma série de apelos de governos que se sentiram compelidos a provar sua legitimidade, por meio das novas normas.

A autora afirma ainda que a observação mais atual, se comparada com aquela realizada em início dos anos 1990, não é mais tão passiva, tendo aprimorado suas técnicas e métodos, com vistas a dispersar quaisquer dúvidas sobre os processos eleitorais. Donno (2013b), reforça que, para o caso das Nações Unidas, a realização de monitoramento é muito mais provável de ocorrer, em especial, em contextos de pós conflito, em países onde a organização está envolvida na construção ou reconstrução de paz, ou ainda, naqueles que já possuem um histórico de intervenção.

\subsubsection{Organização dos Estados Americanos}

Hartlyn, McCoy e Mustillo (2008) defendem que foram vários os meios através dos quais os governos latino-americanos se direcionaram rumo à democracia, mas assumem que o caminho eleitoral gradual, foi um dos principais. Por sua vez, Lean (2012) argumenta que, depois de 1990, o contínuo crescimento do número de eleições ocorreu também, em parte, devido ao crescimento da incidência de processos eleitorais como eleições para assembleias constitucionais, referendos constitucionais e referendos revogatórios.

A OEA esteve presente na maior parte desses processos, não somente em primeiras ou segundas eleições ao longo de transições democráticas, tendo já enviado mais de duzentas missões à região.

Assim como outras organizações que atualizaram seus métodos e técnicas de observação ao longo dos últimos anos, a OEA também o fez, ainda que sua principal preocupação seja com a limpeza do processo. Um enfoque mais complexo sobre a transparência, inclusividade, competitividade e

seus opositores alegavam que a prática era uma clara violação à soberania. Enquanto o último prevaleceu, o peso da soberania começou a diminuir, conforme aumentaram as intervenções humanitárias, fortalecendo a visão de que a democracia e os direitos humanos eram fundamentais (Kelley, 2008). 
periocidade passou a guiar suas ações na área de promoção de boas práticas eleitorais.

Desde 1962, a OEA envia missões aos países americanos, sendo que desses, apenas Argentina, Barbados, Canada, Chile, Trinidad e Tobago e Uruguai não solicitaram observadores estrangeiros à Organização até os dias atuais.

Se ao final da Guerra Fria triplicou o número de governos que realizavam eleições com vistas à transição democrática, é a partir dos anos de 1990 que se pode observar o auge dos envios de missões, mesmo em democracias eleitorais mais consolidadas.

Tabela 2 - Número total de MOEls/OEA por década

\begin{tabular}{lcccccc}
\hline Décadas & & $\mathbf{1 9 6 2 -}$ & $\mathbf{1 9 7 3 -}$ & $\mathbf{1 9 8 3 -}$ & $\mathbf{1 9 9 3 -}$ & $\mathbf{2 0 0 3 - 2 0 1 5}$ \\
& & $\mathbf{1 9 7 2}$ & $\mathbf{1 9 8 2}$ & $\mathbf{1 9 9 2}$ & $\mathbf{2 0 0 2}$ & \\
\hline Número & de & 12 & 7 & 23 & 66 & 130 \\
missões & & & & & & \\
\hline
\end{tabular}

Fonte: Adaptado de Muñoz-Pogossian e Veloso (2015).

As missões da OEA, além de observação, têm ainda uma importante função política. Embora os documentos oficiais insistam na ideia de que os observadores se limitem à observação passiva do processo eleitoral, eles podem vir a desempenhar papel mais ativo na facilitação de negociações e na construção de consenso entre atores em conflito, ou mesmo, auxiliar representantes de organismos eleitorais a esclarecer situações confusas e potencialmente conflituosas. Entre as situações conflituosas, podem ser citadas por exemplo, divergências no processo de contagem de votos oficial, que poderia ser resolvida com a consulta à contagem paralela realizada pelas missões.

Para Legler, Lean e Boniface (2007), a OEA também se tornou importante ator na criação de normas internacionais de segurança e democracia. Através de cooperação com o Pnud e o Centro Carter, a Organização promoveu a padronização dos procedimentos e práticas de observação eleitorais. Da mesma forma, passou a colaborar ativamente com organizações de observação mais novas, como o Caricom, além de participar de processos eleitorais com outras organizações com maior tradição, como o NDI. 


\subsection{Os relatórios das missões e seu uso na avaliação de processos eleitorais}

Ao contrário de grandes organizações internacionais, que buscam atender a uma série de demandas no âmbito de sua atuação, as organizações regionais têm, cada vez mais, buscado direcionar suas ações para um ou outro tema. No caso das eleições, isso pode ser diretamente observado com o surgimento de uma série de organizações regionais especializadas na assistência eleitoral, de um modo geral, e, algumas, de forma mais específica, na observação internacional.

Como detalhado no capítulo anterior fazem parte dessa ampla gama de organizações regionais, que realizam missões de observação na América Latina: Centro Carter, OEA, União Europeia, NDI, IRI, entre outras.

Embora nesse cenário, muitas forneçam ainda, assistência eleitoral, tem destaque o envio de missões por parte da OEA; CC; IRI; ONU; OIF; PE; Ifes, Caricom; NDI e UE, que no período de investigação, enviaram observadores, de fato, e não especialistas da área eleitoral, para os países nos quais estiveram presentes. Por isso, seus relatórios foram escolhidos para composição da tese, ao apresentarem uma visão mais próxima daquela dos observadores, diferente daquela de um profissional de um tribunal superior eleitoral de país vizinho, ou mesmo, de técnicos, especializados no tema das eleições.

Assim, tem-se como principal fonte do estudo a revisão de relatórios de missões de monitoramento internacional e suas recomendações, por se configurarem como importantes ferramentas analíticas. Sua análise permite melhor descrição do momento eleitoral, assim como, identificação de seus aspectos mais importantes, sendo eles meramente técnicos, como a abertura e fechamento dos centros de votação, até os mais sensíveis, como a identificação de fraudes eleitorais ou violência eleitoral.

O uso dos informes como ferramenta no estudo da boa governança democrática, não é algo novo. Na verdade, há uma série de estudos que discutem o seu uso na mensuração da qualidade de um processo eleitoral, de sua integridade ou mesmo na identificação das más práticas observadas (Hartlyn e McCoy, 2006; Birch, 2011; Daxecker e Schneider, 2014; Merloe, 2015). Outros 
ainda, enfatizaram mudanças na própria forma como os relatórios passaram a se referir às eleições, deixando de categorizá-las como "livres e justas", para uma abordagem com uma ênfase maior nas diversas fases que compõem um processo eleitoral (Bjornlund, 2004; Alvarez e Hall, 2008).

Há autores que criticam sua utilização e veem algumas desvantagens, a exemplo das declarações finais, que são feitas logo após o fim do processo eleitoral e podem incorrer em falhas ou então apresentar provas incompletas de que houve problemas (Elklit e Reynolds, 2005, Norris, 2013a, 2013b). Outras críticas advêm do fato de que algumas observações tendem a ser realizadas somente no dia da eleição, podendo enviesar os relatórios, e qualificar uma eleição como atendendo a parâmetros internacionais, sem levar em conta, fraudes pré-eleitorais (Elklit e Svensson, 1997; Hyde e O'Mahoney, 2010) ou, no caso dos países que convidam as missões, permitir somente organizações com pouca experiência (Carothers, 1997; Hyde, 2006; 2011) ou muitas missões ao mesmo tempo (Kelley, 2009) com diferentes metodologias de avaliação. Uma última dificuldade reside no relacionamento que as organizações internacionais mantêm com os governos dos diferentes países, que, em determinado momento, podem requisitar a observação, porém em se tratando de autocracias eleitorais (Diamond, 2004), há maior dificuldade em denunciar irregularidades ou fraudes (Schedler, 2006; Hartlyn, McCoy e Mustillo, 2008; Beaulieu e Hyde, 2009; Kelley, 2012a, 2012b).

No entanto, o uso de relatórios apresenta vantagens quanto sua incorporação como um item importante para avaliação dos índices de democracia nos países. A Freedom House, por exemplo, toma como indicador importante de democratização de um país sua abertura ou não à presença de observadores internacionais. Nos casos em que há impedimentos à observação, como a seleção dos locais em que os observadores atuarão, ou a simples proibição de recebê-los, são vistos em contexto com outros indicadores, para identificação qualitativa da qualidade da democracia de um país (Freedom House, 2015a).

Outra vantagem reside no fato de que são relatórios supervisionados por especialistas e técnicos de organizações internacionais, de modo a garantir sua credibilidade perante a comunidade internacional. Desse ponto de vista, são as principais referências buscadas pelos meios de comunicação em geral e pelos 
governos, para se informar sobre se uma eleição respondeu às normas internacionais de democracia ou não (Donno, 2013; Hyde e Marinov, 2014; Merloe, 2015).

São também uma importante fonte de dados original quando não há recursos para a realização de pesquisas de opinião ou mesmo, quando não há como realizar questionários com base nas análises de especialistas (Freidenberg, 2015).

\subsection{Haiti e México e sua relação com a observação internacional de eleições}

Inicialmente, cabe mencionar que ambos estão incluídos na "grey zone" (Schedler, 2002; Carothers, 2002) discutida e sua classificação através dos índices, embora diversificada, não os coloca como exemplos de democracia liberal, conforme Tabela 3.

\section{Tabela 3 - A democracia no Haiti e México segundo índices globais de democracia em 2015}

\begin{tabular}{|c|c|c|c|c|c|c|c|}
\hline \multirow[b]{2}{*}{ País } & \multicolumn{2}{|c|}{ Freedom House [1] } & \multicolumn{2}{|c|}{$\begin{array}{c}\text { Ranking Global de } \\
\text { Qualidade da } \\
\text { Democracia [2] }\end{array}$} & \multicolumn{3}{|c|}{$\begin{array}{l}\text { Intelligence Unit's Index of } \\
\text { Democracy The Economist [3] }\end{array}$} \\
\hline & $\begin{array}{c}\text { Pontuaçã } \\
\quad 0\end{array}$ & Classificação & $\begin{array}{c}\text { Pontuaçã } \\
\quad 0\end{array}$ & $\begin{array}{c}\text { Rankin } \\
\mathbf{g} \\
\text { mundia } \\
\mathbf{~}\end{array}$ & $\begin{array}{c}\text { Pontuaçã } \\
\text { o }\end{array}$ & $\begin{array}{c}\text { Rankin } \\
\mathbf{g} \\
\text { mundia } \\
\mathbf{l}\end{array}$ & $\begin{array}{c}\text { Classificaçã } \\
0\end{array}$ \\
\hline Haiti & 5 & $\begin{array}{c}\text { Parcialmente } \\
\text { Livre/Democrac } \\
\text { ia Eleitoral }\end{array}$ & 42,7 & 102 & 3,94 & 119 & $\begin{array}{l}\text { Regime } \\
\text { autoritário }\end{array}$ \\
\hline $\begin{array}{c}\text { Méxic } \\
\text { o }\end{array}$ & 3 & $\begin{array}{c}\text { Parcialmente } \\
\text { Livre/Democrac } \\
\text { ia Eleitoral }\end{array}$ & 57,9 & 60 & 6,55 & 66 & $\begin{array}{c}\text { Democracia } \\
\text { imperfeita }\end{array}$ \\
\hline \multicolumn{8}{|c|}{$\begin{array}{l}\text { [1] A Freedom House tem uma média de pontuação de } 1 \text { (melhor) a } 7 \text { (pior). Ela classifica os } \\
\text { países como livres ( } 1.0 \text { a } 2.5) \text {, parcialmente livres ( } 3.0 \text { a } 5.0) \text { e não livres ( } 5.5 \text { a } 7.0) \text {. } \\
\text { [2] O Ranking Global de Qualidade da Democracia tem uma medida de pontuação de } 1 \text { (pior) } \\
\text { a } 100 \text { (melhor), para classificação no ranking mundial e agrega a performance de vários } \\
\text { indicadores em sua análise, em uma pontuação que os classifica entre aquelas de melhor } \\
\text { qualidade (67.6 a } 100) \text {, qualidade mediana ( } 53 \text { a } 67.5 \text { ) e pouca qualidade ( } 0 \text { a } 52.9) \text {. } \\
\text { [3] O Intelligence Unit's Index of Democracy The Economist tem uma medida de classificação } \\
\text { de } 1 \text { (pior) a } 10 \text { (melhor), para indicar a posição dos países no ranking mundial e dos tipos de } \\
\text { regime, que variam entre democracias consolidadas ( } 8 \text { a 10), democracias imperfeitas (6 a } \\
\text { 7.9), regimes híbridos (4 a 5.9) e regimes autoritários (0 a 3.9). } \\
\text { Fontes: Freedom House (2015a); Campbell (2015); Kekic (2015). }\end{array}$} \\
\hline
\end{tabular}

Note-se que, neste ano, embora a Freedom House considere o Haiti uma democracia eleitoral, o Intelligence Unit's Index of Democracy The Economist 
coloca o país como um regime autoritário, junto a países como China, Camarões e Cuba (Kekic, 2015). Para a Freedom House, toda democracia liberal é uma democracia eleitoral, mas nem todas as democracias eleitorais são qualificadas como liberais, com base em seu quadro de análise conceitual e metodológico.

Para o índice de liberdade, uma democracia eleitoral deve contar com "certos requisitos mínimos padrões, que são: (1) sistema político competitivo e multipartidário; (2) sufrágio universal para todos os cidadãos adultos; (3) eleições regularmente conduzidas em condições de sigilo de votação razoável, com ausência de fraude eleitoral maciça, e cujos resultados são representativos da vontade popular e; (4) acesso público significativo dos partidos políticos aos eleitores através dos meios de comunicação e por meio de campanha política (Freedom House, 2015b).

Para Campbell (2008), ao cumprimento desses critérios corresponderia dizer que uma democracia liberal demanda padrões suficientes de democracia, e não somente padrões mínimos. "A democracia liberal vai além dos padrões mínimos de uma democracia eleitoral. Nesse contexto, a democracia liberal representa uma manifestação mais elevada de democracia" (p. 18).

O último índice divulgado mostrou que o número de democracias eleitorais tem crescido a cada ano. Em 1990, logo após o fim da Guerra Fria, a Freedom House contabilizou aproximadamente setenta e seis democracias eleitorais. Em 2015, o número de países nessa classificação tinha aumentado para cento e vinte e cinco, sendo que, noventa desses países foram classificados como livres.

O Gráfico 1 mostra a distribuição do total de democracias eleitorais no mundo ao longo dos anos.

\section{Gráfico 1 - Total de democracias eleitorais no mundo por ano, 1990-2015}




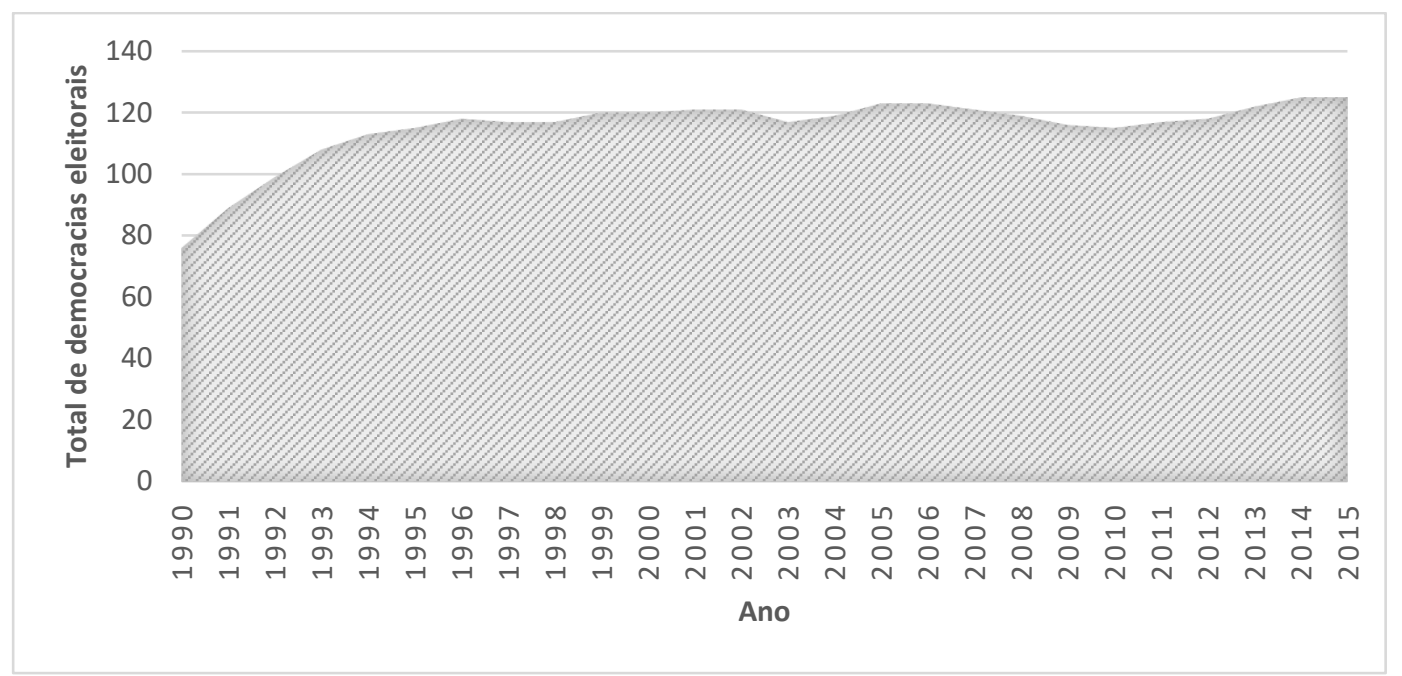

Fonte: Freedom House, 2016.

Segue-se a classificação do Haiti e do México para todo o período de análise, segundo a categoria de democracia eleitoral da Freedom House:

Tabela 4 - Classificação como democracia eleitoral, sim ou não, pela Freedom House, do Haiti e México, entre 1990-2015

\begin{tabular}{ccc}
\hline \multirow{2}{*}{ Ano } & \multicolumn{2}{c}{ Países } \\
\cline { 2 - 3 } & Haiti & México \\
\hline 1990 & Sim & Não \\
1991 & Não & Não \\
1992 & Não & Não \\
1993 & Não & Não \\
1994 & Sim & Não \\
1995 & Sim & Não \\
1996 & Sim & Não \\
1997 & Sim & Não \\
1998 & Sim & Não \\
1999 & Sim & Não \\
2000 & Não & Sim \\
2001 & Não & Sim \\
2002 & Não & Sim \\
2003 & Não & Sim \\
2004 & Não & Sim \\
2005 & Não & Sim \\
2006 & Não & Sim \\
2007 & Sim & Sim \\
2008 & Sim & Sim \\
2009 & Sim & Sim \\
2010 & Sim & Sim \\
2011 & Não & Sim \\
2012 & Não & Sim \\
2013 & Não & Sim \\
2014 & Não & Sim \\
2015 & Não & Sim \\
\hline Fonte: Freedom House (2015a) & & \\
& &
\end{tabular}


Ou seja, enquanto o México mostra consistência em sua mudança de status para democracia eleitoral, a partir do ano 2000, Haiti, por assim dizer, sai e entra desta categoria várias vezes ao longo do período.

Entre os motivos que levaram a essa flutuação na classificação do Haiti estão as turbulentas eleições realizadas no país, levando a graves crises políticas. Os constantes adiamentos dos processos eleitorais foram considerados um grave indício de violação aos direitos políticos e liberdades civis dos haitianos (Freedom House, 2015; 2016).

Assim, o governo haitiano viu no convite à observação, a oportunidade de melhorar a imagem do país externamente, de modo que desde suas eleições fundacionais, essa é uma tradição que tem se mantido.

Em resumo, no ano de 1987, a população haitiana sofria com uma série de sucessivos episódios de violência e intimidação, mesmo após o anúncio de novas eleições. Em setembro de 1988, contudo, o general Prosper Avril, tomou o poder em um golpe militar, porém renunciou à presidência em 10 de março do mesmo ano, após um período de oposição popular prolongada e intensa contra seu governo. Em meio à crise política instalada após a saída do general, Ertha Pascal-Trouillot, membro da Suprema Corte do país, assumiu a presidência como a primeira mulher à frente da condução do país. Como tentativa de amenizar os ânimos, O Conselho Eleitoral Provisório (CEP) anunciou a realização de novas eleições, que, no entanto, após novos episódios de violência política, foram adiadas (Kessing's, 03/01/1990). As eleições finalmente realizaram-se em dezembro de 1990, e foram realizadas com a presença de observadores da ONU, um pedido que havia sido feito pelo general Avril, pouco antes de sua renúncia, e que, depois, foi formalizado por Pascal-Trouillot (Fox e Roth, 2000; Santa-Cruz, 2013).

Como argumenta Franck (1992), as eleições de 1990 no Haiti são emblemáticas, do ponto de vista normativo, porque representaram "a primeira instância na qual as Nações Unidas agindo sob demanda de um governo nacional, intervieram em um processo eleitoral com o objetivo somente de legitimar seus resultados" (pp. 72-73). O mesmo argumento é feito por SantaCruz (2013), uma vez que o autor entende o caso do Haiti de forma diferente da experiência nicaraguense, envolta em projeto maior de processo de paz 
regional ${ }^{54}$. Segundo ele, as eleições haitianas tinham mais a ver com o estabelecimento de regime democrático em um estado-membro soberano (idem).

O Grupo de Observadores das Nações Unidas para a Verificação das Eleições no Haiti (ONUVEH) em outubro de 1990 e contou com o envio de cerca de 260 observadores ao país (Badie, Berg Schlosser e Morlino, 2011).

No primeiro turno das eleições quase mil colégios eleitorais receberam a visita dos observadores estrangeiros, que não registraram nenhum tipo de graves irregularidades - a exemplo de episódios de violência isolados ou alteração de cédulas de votação. O padre Jean Bertrand Aristide ${ }^{55}$, do Front Nacional pela Democracia e Mudança, saiu vencedor, tendo permanecido à frente da presidência do país até meados de 1991, quando o general Raoul Cédras o retirou do cargo mediante um golpe de Estado.

As eleições foram importantes não somente do ponto de vista do fortalecimento democrático, logo abalado por novo golpe de Estado, como também foi uma indicação a doadores internacionais de que o país desejava cumprir com requisitos normativos, em troca de ajuda econômica. Inclusive, o vice-presidente estadunidense Dan Quayle, declarou momentos antes do pleito que se o Haiti não se mostrasse democrático e nem respeitoso o suficiente aos direitos humanos, "ele não seria beneficiário de dinheiro dos contribuintes norteamericanos" (Shenon, 10/08/1990). Em sua fala, ele disse ainda que os Estados Unidos contribuiriam com aproximadamente 60 milhões de dólares em ajuda internacional, além de 3 milhões de dólares a serem utilizados pelo Conselho Eleitoral Provisório do Haiti, como forma de garantir eleições justas (idem).

A pressão para que o Haiti realizasse eleições, garantindo respeito aos direitos humanos, sendo as eleições um desses direitos, era retrato das mudanças de condicionalidade impostas pelas agências internacionais, para que os governos pudessem receber esses recursos. A partir daí as eleições no país

\footnotetext{
54 Também são exemplos de observações conduzidas pela ONU como parte de estratégia de estabelecimento da paz as eleições da Namíbia (1990), Angola (1992), El Salvador (1994), Timor Leste (1999), Camboja (2003), entre outras.

${ }_{55} \mathrm{O}$ padre Jean-Bertrand Aristide, um radical padre católico romano, derrotou dez outros candidatos para conseguir uma vitória esmagadora nas eleições presidenciais de 16 de dezembro. Ele recebeu cerca de $67 \%$ dos votos emitidos. Marc Bazin, da Aliança Nacional para a Democracia e o Progresso e ex-funcionário do Banco Mundial, ficou em segundo lugar com $15 \%$ dos votos (Kessing's, 01/12/1990).
} 
passaram a ser realizadas de forma periódica, com ampla presença de observadores estrangeiros, sendo estes testemunhos dos esforços do governo haitiano em cumprir com as novas normas.

Muito ainda precisa ser feito, para que o Haiti consolide sua transição. Isso é dito porque entre os desafios que levam a diferentes classificações da Freedom House, quanto ao seu tipo de regime político, está: o fraco sistema jurídico, a existência de alguns órgãos do governo que não são totalmente independentes, corrupção e violência política. "A capacidade de governança do país, já limitada, ficou menor após o terremoto de 2010. Pobreza em massa e disparidades econômicas entre a classe mais privilegiada e maioria da população" (Taft-Morales, 2011, p.1) também contribuem a variação quanto à sua classificação no índice.

Já o México veio a receber missões somente após muita resistência, em virtude da interpretação do governo do país, de que a observação violava sua soberania nacional. Da mesma forma que o Haiti, o país passou a receber observadores como uma tentativa de melhorar sua imagem internacionalmente, haja vista que era tido por outros governos da região e, até mesmo por parceiros na área econômica, como um regime fechado. Com o fortalecimento do ideal democrático como o tipo de regime mais desejável no Ocidente, o país passou a convidar observadores e realizar mudanças em seu processo eleitoral, com vistas a se adequar ao novo ambiente internacional ${ }^{56}$.

De forma breve, em 1988, Carlos Salinas, do Partido Revolucionário Institucional (PRI) assumiu a presidência do México, depois de uma eleição muito controversa. Os primeiros resultados apontavam a vitória do adversário Cuauhtémoc Cárdenas, do Partido da Revolução Democrática (PRD). Depois de um misterioso incêndio no Congresso da União, onde as cédulas eleitorais estavam armazenadas, Salinas foi declarado vencedor do pleito (Latinoamericana, 2007, p.776).

Nessa época, a OEA ampliara o escopo e tamanho de suas missões na América Latina, na tentativa de torná-las um instrumento para a aplicação da

\footnotetext{
56 Hyde (2011) chama a atenção para o esforço mnemônico de muitos países que desejavam ser reconhecidos internacionalmente como democráticos e que, para isso, passaram a incorporar práticas democráticas em seus processos políticos, sem, no entanto, se democratizar. O México convidou observadores para suas eleições de 1994, porém é só nos anos 2000 , que os especialistas datam o início de sua democratização.
} 
Carta Democrática. E como argumentado por Santa-Cruz (2009; 2013), neste momento, a observação era vista pelo governo mexicano como uma violação da soberania do país, uma vez que, para ele, as eleições eram assunto doméstico. Como consequência, a observação internacional não era bem vista por Salinas, que se opunham fortemente a sua presença, apesar de que a observação à época já se expandia na América Latina (idem).

Mas, com o avanço do movimento zapatista, o discurso governamental começou a mudar, sobretudo à medida que novas eleições se aproximavam no início dos anos 1990 e com o medo crescente de que a violência no sul do país, pudessem se espalhar para as outras regiões.

Além disso:

\begin{abstract}
"Com a revolta zapatista e o assassinato do candidato do partido do governo, o regime mexicano enfrentou uma de suas crises mais graves de credibilidade, e a aceitação de monitores estrangeiros foi sem dúvida um movimento calculado por parte do governo de Salinas" (idem, p.1)
\end{abstract}

Para Pastor (1990), as eleições locais que se seguiram foram um teste para a promessa de Salinas de democratizar o país, e o Partido da Ação Nacional (PAN) já tinha, a essa altura, iniciado um processo de internacionalização das eleições ao "levar suas queixas de fraude (pré) eleitoral à Organização dos Estados Americanos (OEA) " (p. 14).

Em 1991, o PRD convidou quatro membros do Partido da Nova Democracia (PND) do Canadá para acompanhar as eleições que seriam realizadas em fevereiro daquele ano, no estado de Morelos. "Mas a experiência não foi um sucesso. Os observadores não falavam espanhol, sua chegada a Morelos ocorreu dois dias antes das eleições, e eles nem mesmo visitaram os locais de votação. No entanto, a presença dos observadores gerou reações adversas" (idem, p. 6-7).

Mais tarde naquele ano, as ONGs locais iniciaram o monitoramento das eleições de forma mais consistente, inspiradas na experiência canadense, e motivadas pela suspeita de fraude eleitoral ocorrida em 1988. No entanto, a presença de estrangeiros não era algo ainda aceitável nem por políticos e nem por pessoas locais (Crespo, 1992).

Com a revolta do Exército Zapatista de Libertação Nacional (EZLN) foi necessária uma reformulação das regras e procedimentos eleitorais: a "crença 
de que as eleições presidenciais de 1994 seriam livres era essencial para travar a propagação da violência política e as respostas anti-sistêmicas às adversidades políticas (Scherlen, 1998, p.4).

Na época, Pastor (1990) reconhecera um ambiente muito instável no qual argumentou que "o respeito pelos direitos humanos básicos - o direito de não ser torturado e abusado, sobretudo pela polícia - é um passo crucial em direção a um México mais civilizado. No entanto, a democracia é um pouco mais difícil. Ela exige que o governo respeite o voto dos eleitores" (p.16). Neste momento, era grande a difusão dos valores dos direitos humanos, que se tornavam cada dia mais fortes. Esta agenda foi gradualmente se expandindo para incluir processos eleitorais como parte dela.

À medida que a bandeira da democracia ganhava terreno em todo o mundo: "o sistema político mexicano parecia cada vez mais um anacronismo autoritário semelhante a outros regimes tão impopulares como aqueles de Burma (Mianmar), China, Cuba, Vietnam e Indonésia" (Chand, 1997, p. 553).

Esta situação não era mais compatível com os postulados de um regime democrático e com os direitos humanos em ascensão, Salinas concordou, então, com a assinatura de um documento que poderia restabelecer a paz para fazer avançar a aspiração de democratização do México.

Em 1994, o documento "Vinte compromissos para a Democracia" foi a pedra angular para trazer de volta a paz, tendo sido assinado por representantes da sociedade civil, governo e partidos políticos. Ele também serviu para demonstrar aos parceiros internacionais, os esforços de Salinas em fazer um bom trabalho durante seu mandato. Como parte deste esforço para dar a impressão de um país confiável para os negócios "eleições presidenciais transparentes sem qualquer controvérsia eram um ingrediente essencial para manter essa imagem" (Scherlen, 1998), e mais tarde, nesse ano, seguindo as sugestões do documento, o governo permitiu, pela primeira vez, a presença de observadores nacionais acreditados e de visitantes estrangeiros para revisar e relatar as eleições" (idem).

Nos anos 2000, o México passou a ser classificado como livre pela Freedom House após a realização de um processo considerado livre e justo, após anos de governo do PRI. A eleição foi acompanhada de uma diversificação contínua nos meios de comunicação e uma sociedade civil cada vez mais 
engajada, com a emergência de novas organizações políticas (Freedom House, 2016).

Por fim, ambos os países ainda convivem com elementos que limitam a qualidade de suas democracias, destarte as iniciativas para sua melhoria, como o convite à observação internacional.

\subsection{Desenho de pesquisa}

\subsubsection{Amostra}

De modo a avaliar o impacto das missões para a boa governança eleitoral no Haiti e México, inicialmente, criamos um banco de dados com todas as rodadas de eleições no período de 1990 a 2015. Os dados têm origem no banco de dados de Eleições Nacionais em Democracias e Anocracias (Nelda) (Hyde e Marinov, 2012) e foram complementados pelo Guia de Eleições da Fundação Internacional de Sistemas Eleitorais (Ifes) (Ifes, 2016) e pelo Projeto de Administração e Custo das Eleições (ACE Project) (ACE Project, 2016).

O Nelda inclui os países que realizaram eleições competitivas desde 1945, tendo sido extraído somente o período de interesse. Ele é baseado em informações de 157 países independentes, com uma população superior a 500 mil habitantes e que mantiveram pelo menos uma eleição nacional a partir de 1945. Já o Ifes disponibiliza um calendário eleitoral de eleições realizadas em todos os países conforme seu tipo (presidenciais ou outras).

Nossas unidades de análise são as eleições para o Executivo e Legislativo que receberam missões de monitoramento, de modo que para identificar quais eleições entrariam na amostra, utilizamos os dados disponibilizados pelo ACE Project, portal que agrega uma série de informações sobre processos eleitorais de todo o mundo. Além da checagem dos dados nos sites das próprias organizações internacionais.

Durante o período analisado, os dois países viveram um intenso calendário eleitoral, tendo muitas das votações ocorrido para escolha de novos presidentes e tantas outras com vistas a ocupar cargos no legislativo e ao nível 
municipal. O banco de dados inclui 32 eleições e 80 relatórios sob o período de análise $e^{57}$.

\section{Tabela 5 - Eleições realizadas entre 1990 e 2015 no Haiti e México por ano, data, tipo e organização internacional de observação eleitoral}

\begin{tabular}{|c|c|c|c|c|}
\hline País & Ano & Data & Tipo & $\begin{array}{l}\text { Organização } \\
\text { Internacional }\end{array}$ \\
\hline \multirow{19}{*}{ Haiti } & 1990 & $16 / \mathrm{dez}$ & Legislativo & IFES, IRI, CC, ONU, OEA \\
\hline & 1990 & 16/dez & Executivo & ONU, OEA \\
\hline & 1991 & 20/jan & Legislativo & ONU, OEA \\
\hline & 1995 & 25/jun & Legislativo & IRI, CC, ONU, OEA \\
\hline & 1995 & $17 /$ set & Legislativo & IRI, CC, ONU, OEA \\
\hline & 1995 & 17/dez & Executivo & IRI, CC, ONU, OEA \\
\hline & 1997 & $06 / a b r$ & Legislativo & IRI \\
\hline & 2000 & $21 /$ mai & Legislativo & OEA, CC, OIF \\
\hline & 2000 & 09/jul & Legislativo & OEA, CC, OIF \\
\hline & 2000 & $26 /$ nov & Executivo & OEA, CC, OIF \\
\hline & 2006 & $07 / \mathrm{fev}$ & Legislativo & PE, OIF, UE \\
\hline & 2006 & $21 / a b r$ & Legislativo & PE, OIF, UE \\
\hline & 2006 & $07 / \mathrm{fev}$ & Executivo & PE, OIF, UE \\
\hline & 2010 & $28 /$ nov & Legislativo & OIF, OEA/CARICOM \\
\hline & 2010 & $29 /$ nov & Executivo & OIF, OEA/CARICOM \\
\hline & 2011 & $20 /$ mar & Executivo & OIF, OEA/CARICOM \\
\hline & 2015 & 09/ago & Legislativo & OEA, CC, UE \\
\hline & 2015 & $25 /$ out & Executivo & OEA, CC, UE \\
\hline & 2015 & 25/out & Legislativo & OEA, CC, UE \\
\hline \multirow{13}{*}{ México } & 1991 & 18/ago & Legislativo & Nenhuma \\
\hline & 1994 & 21/ago & Legislativo & IFES, CC \\
\hline & 1994 & 21/ago & Executivo & IFES, NDI/IRI \\
\hline & 1997 & 06/jul & Legislativo & $\mathrm{CC}$ \\
\hline & 2000 & 02/jul & Legislativo & NDI, IRI, CC, PE \\
\hline & 2000 & 02/jul & Executivo & NDI, IRI, CC, PE \\
\hline & 2003 & 06/jul & Legislativo & ONU \\
\hline & 2006 & 02/jul & Legislativo & UE, NDI \\
\hline & 2006 & 02/jul & Executivo & UE, NDI \\
\hline & 2009 & 05/jul & Legislativo & OEA \\
\hline & 2012 & 01/jul & Legislativo & OEA, UE \\
\hline & 2012 & 01/jul & Executivo & OEA, UE \\
\hline & 2015 & 06/jul & Legislativo & OEA, CC \\
\hline
\end{tabular}

Fontes: Nelda (2012), IFES e ACE Project.

O Haiti promoveu eleições que foram adiadas de forma recorrente ou que foram realizadas mais de uma vez. Já o México manteve a regularidade de seus processos eleitorais, sendo que o recebimento de estrangeiros só passou a ser

57 Importante lembrar que o Haiti passou a autorizar a observação em 1990, ao passo que o México, só o fez em 1994. No entanto, já haviam missões informais nos países antes dessas datas. 
uma prática aceita no país, três anos depois das primeiras eleições com limitada competição política, dos anos 1990.

\subsubsection{Variáveis e indicadores}

Analisamos os relatórios das missões de observação eleitoral internacionais, que reconhecidamente participaram dos processos eleitorais no Haiti e México, entre 1990 e 2015 em busca de indicadores de boa governança eleitoral. Para isso, agrupamos indicadores relativos à atuação dos observadores nas missões, que, em outras palavras, são as práticas de boa governança eleitoral que devem estar presentes nos países para que as eleições estejam de acordo com normas internacionais democráticas. Realizamos a seleção dos indicadores com base na recorrência destes nos relatórios das missões analisadas. Seguimos a organização já existente nos relatórios, que divide as tarefas de observação entre os períodos pré-eleitoral, dia da eleição e pós-eleitoral. Estabelecemos, então um índice de boa governança eleitoral a ser descrito abaixo ${ }^{58}$.

Além das observações, todas as missões fazem recomendações aos governos, de uma forma geral, e aos organismos eleitorais com vistas à melhoria do processo como um todo, em cada uma de suas etapas. Em seguida procuramos avaliar o impacto das recomendações das MOEls, isto é, até que ponto as recomendações de uma eleição tinham sido atendidas na eleição seguinte.

\subsubsection{Análise empírica}

A eleição é assunto complexo e declarar que uma eleição foi livre e justa ao final do dia de votação não é somente um clichê como não faz jus ao seu conteúdo. Assim, as missões tendem a observar as eleições mais através dos compromissos assumidos como membros de uma comunidade de nações democráticas. Eles veem o que acontece ao longo do processo eleitoral, e

\footnotetext{
58 Todas as missões de monitoramento eleitoral internacionais possuem sua própria metodologia de avaliação, mas os critérios que seguem são muito semelhantes, com pouca variação entre o que deve ser aprimorado ou não.
} 
determinam até que ponto o que foi visto corresponde ou não às normas internacionais. Tudo isso, com vistas a informar ao governo solicitante como melhorar o processo eleitoral naquele país.

É difícil também aos observadores determinar até que ponto uma eleição cumpriu ou não com alguns procedimentos básicos, ou mesmo, avaliar de forma geral se um processo eleitoral cumpriu minimamente com normas internacionais democráticas. Há alguns anos as missões deixaram de classificar um processo como "livre e justo" e passaram a preferir declarações mais abrangentes, com foco no processo.

Além disso, as organizações de observação passaram a contar com uma lista que devem ser atendidos ao longo dos processos eleitorais, para que se mantenha a qualidade e integridade de uma eleição.

Segundo Carroll e Davis-Roberts (2013), esse check list fornece um caminho mais promissor para a promoção de um consenso aprofundado, sobre quais elementos compõem as "normas internacionais para eleições democráticas", assim como, os critérios de avaliação utilizados pelos grupos de observadores.

Ainda que atualmente exista uma série de organizações internacionais com suas próprias metodologias de avaliação, os grupos com maior tradição na área $(\mathrm{GEO})^{59}$, trabalham com o que muitos autores denominaram como obrigações relativas ao processo eleitoral em si, ou seja, aquelas obrigações que são parte da cultura política do país, ao mesmo tempo em que cumprem com normas internacionais democráticas (Norris, 2012; Freidenberg, 2015; DIPOE, 2005).

Muitas missões podem estar presentes em uma dada eleição e, nem sempre, suas visões serão unívocas (Kelley, 2012a, 2012b). Por exemplo, enquanto uma missão pode ter considerado o acesso aos centros de votação como adequados, esta pode ter recebido uma sugestão de melhoria por parte de outra organização ou mesmo, podem ter sido relatados episódios de violência

${ }^{59}$ A Organização Eleitoral Global (GEO) reúne uma série de organizações de reforma e apoio à democracia, aí incluídas ONGls, organizações bilaterais e intergovernamentais, Nações Unidas, organizações governamentais financiadas pelos governos, ONGs e grupos de advocacia internacionais. 
eleitoral por um grupo de observadores e, por outro não. Daí a importância de se analisar o conteúdo dos relatórios divulgados.

Levando tudo isso em conta, identificamos a partir dos relatórios das MOEls, os indicadores de boa governança eleitoral. Para isso, identificamos os itens mais frequentes em cada uma das eleições indicando com "sim", aqueles que estão presentes e são desejáveis e, portanto, atendem às normas internacionais democráticas. O conjunto dos indicadores "sim" compõem as chamadas boas práticas (Norris, 2012; Hoyos, 2014; Birch, 2011; Freidenberg, 2015). Esse procedimento foi repetido para cada uma das fases de observação: pré-eleitoral, durante a eleição e pós-eleitoral.

Ao final da análise dos relatórios, se destacaram doze indicadores para cada uma das fases da jornada eleitoral mais recorrentes nos processos eleitorais analisados:

\section{Quadro 3 - Indicadores de boa governança eleitoral no período pré- eleitoral, dia da eleição e pós-eleitoral}

\begin{tabular}{|c|c|}
\hline Período & Observações \\
\hline Pré-eleitoral & $\begin{array}{l}\text { Existência de um organismo eleitoral independente } \\
\text { Ausência de grupos armados } \\
\text { Respeito ao calendário eleitoral } \\
\text { Fiscalização de financiamento ilegal de campanha } \\
\text { Coordenação efetiva de centros eleitorais } \\
\text { Ausência de focos de violência eleitoral } \\
\text { Capacitação de oficiais eleitorais } \\
\text { Educação cívica sobre importância do voto } \\
\text { Ausência de campanhas de desmobilização de eleitores } \\
\text { Competição política } \\
\text { Fornecimento de credenciais aos eleitores } \\
\text { Ausência de erros no registro de eleitores }\end{array}$ \\
\hline Dia da eleição & $\begin{array}{l}\text { Ausência de erros nas listas eleitorais } \\
\text { Garantia de segurança dos eleitores } \\
\text { Presença de material eleitoral e membros de mesa na abertura dos } \\
\text { centros } \\
\text { Pontualidade na abertura dos centros de votação } \\
\text { Fácil acesso dos eleitores aos centros de votação } \\
\text { Mulheres e grupos minoritários presentes } \\
\text { Eleitor informado sobre conteúdo do voto e como votar } \\
\text { Bom preenchimento das atas eleitorais (sem erros e rasuras) } \\
\text { Ausência de focos de violência e intimidação de eleitores } \\
\text { Garantia do segredo de voto nas cabines } \\
\text { Fácil identificação dos centros de votação pelos eleitores } \\
\text { Ausência de práticas ilegais de voto como compra e coerção }\end{array}$ \\
\hline Pós-eleitoral & $\begin{array}{l}\text { Transporte adequado de material sensível para contagem } \\
\text { Fechamento do centro no horário estipulado pela lei } \\
\text { Contagem adequada preliminar e final dos votos } \\
\text { Rápida divulgação de resultados } \\
\text { Pouca divergência entre resultados preliminar e final }\end{array}$ \\
\hline
\end{tabular}


Existência de instância para análise de denúncias

Padronização de procedimentos entre centro de votação

Aceitação dos resultados finais por candidatos e oposição

Instrumentos confiáveis de contagem e tabulação

Ausência de muitos votos em um candidato apenas

Ausência de violência pós-eleitoral

Baixo índice de abstenções (presença e voto)

Fonte: elaboração própria a partir da análise dos relatórios da amostra selecionada.

O índice de boa governança eleitoral foi calculado pela proporção total de "sims" obtidos em todas as eleições em relação ao máximo de "sims" possíveis de serem obtidos em todas as eleições, podendo variar de 1 (máximo de governança eleitoral) a 0 (governança eleitoral nula). Calculamos um índice para cada fase da observação. Um índice geral de boa governança eleitoral para cada país pode ser calculado pela média aritmética dos índices de cada fase da observação.

Os índices de boa governança eleitoral podem ser ordenados da seguinte forma:

\begin{tabular}{c}
\hline Índice de boa governança eleitoral \\
\hline 0.80 a $1.00 \rightarrow$ Alto \\
0.40 a $0.79 \rightarrow$ Médio \\
0.00 a $0.39 \rightarrow$ Baixo \\
\hline
\end{tabular}

Feito isso, utilizamos a mesma metodologia para calcular um índice de implementação das MOEls na governança eleitoral dos países, a partir das recomendações das missões para as próximas eleições no que se refere aos indicadores de governança eleitoral definidos (Cf. Quadro 4)

O índice do impacto das recomendações das missões pode igualmente ser calculado pela proporção total de "sim" obtida em todas as eleições analisadas em relação ao máximo de "sim' possíveis de serem obtidos em todas as eleições consideradas, podendo variar de 1 (máximo impacto na governança eleitoral) a 0 (impacto nulo na governança eleitoral).

\section{Quadro 4 - Classificação das MOEls segundo Índice de Boa Governança Eleitoral (observação e recomendações)}

$\begin{array}{lll}\text { País Observação } & \text { Recomendações }\end{array}$




\begin{tabular}{|c|c|c|c|c|c|c|}
\hline \multirow{9}{*}{ Haiti } & \multirow[b]{3}{*}{$\begin{array}{l}\text { Pré- } \\
\text { eleitoral }\end{array}$} & Total sim & 84 & \multirow[b]{3}{*}{$\begin{array}{l}\text { Pré- } \\
\text { eleitoral }\end{array}$} & Total sim & 90 \\
\hline & & Total não & 144 & & Total não & 138 \\
\hline & & $\begin{array}{l}\text { Índice de } \\
\text { governança } \\
\text { eleitoral }\end{array}$ & $\begin{array}{r}0.36 \\
\text { Baixo }\end{array}$ & & $\begin{array}{l}\text { Índice de } \\
\text { implementação } \\
\text { das } \\
\text { recomendações }\end{array}$ & $\begin{array}{r}0.39 \\
\text { Baixo }\end{array}$ \\
\hline & \multirow[b]{3}{*}{$\begin{array}{l}\text { Dia da } \\
\text { eleição }\end{array}$} & Total sim & 91 & \multirow[b]{3}{*}{$\begin{array}{l}\text { Dia da } \\
\text { eleição }\end{array}$} & Total sim & 63 \\
\hline & & Total não & 137 & & Total não & 135 \\
\hline & & $\begin{array}{l}\text { Índice de } \\
\text { governança } \\
\text { eleitoral }\end{array}$ & $\begin{array}{r}0.39 \\
\text { Baixo }\end{array}$ & & $\begin{array}{l}\text { Índice de } \\
\text { implementação } \\
\text { das } \\
\text { recomendações }\end{array}$ & $\begin{array}{r}0.27 \\
\text { Baixo }\end{array}$ \\
\hline & \multirow[b]{3}{*}{$\begin{array}{l}\text { Pós- } \\
\text { eleitoral }\end{array}$} & Total sim & 74 & \multirow[b]{3}{*}{$\begin{array}{l}\text { Pós- } \\
\text { eleitoral }\end{array}$} & Total sim & 76 \\
\hline & & Total não & 154 & & Total não & 152 \\
\hline & & $\begin{array}{l}\text { Índice de } \\
\text { governança } \\
\text { eleitoral }\end{array}$ & $\begin{array}{r}0.32 \\
\text { Baixo }\end{array}$ & & $\begin{array}{l}\text { Índice de } \\
\text { implementação } \\
\text { das } \\
\text { recomendações }\end{array}$ & $\begin{array}{r}0.33 \\
\text { Baixo }\end{array}$ \\
\hline \multirow{9}{*}{$\begin{array}{c}\text { Méxic } \\
0\end{array}$} & \multirow[b]{3}{*}{$\begin{array}{l}\text { Pré- } \\
\text { eleitoral }\end{array}$} & Total sim & 104 & \multirow[b]{3}{*}{$\begin{array}{l}\text { Pré- } \\
\text { eleitoral }\end{array}$} & Total sim & 110 \\
\hline & & Total não & 40 & & Total não & 34 \\
\hline & & $\begin{array}{l}\text { Índice de } \\
\text { governança } \\
\text { eleitoral }\end{array}$ & $\begin{array}{r}0.72 \\
\text { Médio }\end{array}$ & & $\begin{array}{l}\text { Índice de } \\
\text { implementação } \\
\text { das } \\
\text { recomendações }\end{array}$ & $\begin{array}{r}0.76 \\
\text { Médio }\end{array}$ \\
\hline & \multirow[b]{3}{*}{$\begin{array}{l}\text { Dia da } \\
\text { eleição }\end{array}$} & Total sim & 55 & \multirow[b]{3}{*}{$\begin{array}{l}\text { Dia da } \\
\text { eleição }\end{array}$} & Total sim & 66 \\
\hline & & Total não & 89 & & Total não & 78 \\
\hline & & $\begin{array}{l}\text { Índice de } \\
\text { governança } \\
\text { eleitoral }\end{array}$ & $\begin{array}{r}0.38 \\
\text { Baixo }\end{array}$ & & $\begin{array}{l}\text { Índice de } \\
\text { implementação } \\
\text { das } \\
\text { recomendações }\end{array}$ & $\begin{array}{r}0.45 \\
\text { Médio }\end{array}$ \\
\hline & \multirow[b]{3}{*}{$\begin{array}{l}\text { Pós- } \\
\text { eleitoral }\end{array}$} & Total sim & 108 & \multirow[b]{3}{*}{$\begin{array}{l}\text { Pós- } \\
\text { eleitoral }\end{array}$} & Total sim & 105 \\
\hline & & Total não & 36 & & Total não & 39 \\
\hline & & $\begin{array}{l}\text { Índice de } \\
\text { governança } \\
\text { eleitoral }\end{array}$ & $\begin{array}{r}0.75 \\
\text { Médio }\end{array}$ & & $\begin{array}{l}\text { Índice de } \\
\text { implementação } \\
\text { das } \\
\text { recomendações }\end{array}$ & $\begin{array}{r}0.72 \\
\text { Médio }\end{array}$ \\
\hline
\end{tabular}

Fonte: Relatórios das missões de observação eleitoral internacionais. Elaboração própria.

Os capítulos finais da tese são dedicados à análise de estudos de caso do Haiti e México, democracias eleitorais, segundo o paradigma de transição (Carothers, 2002), ou seja, que possuem características diferentes daquelas de democracias consolidadas e onde a observação internacional poderia contribuir de forma mais incisiva.

Carroll e Davis-Roberts (2013) citam ainda o desafio da avaliação final consensual entre os observadores sobre um determinado processo. Para os autores, "é necessário mais que uma simples análise do grau em que a eleição 
atingiu normas internacionais" (p. 93), sendo necessário considerar uma série de outros fatores, aí incluídos, "a margem de vitória nos resultados finais, e se problemas e falhas para cumprir com requisitos democráticos foram grandes a ponto de influenciar - ou ter algum impacto - nos resultados finais" (idem, p.93). Por isso, mesmo as avaliações que são feitas com base nas normas internacionais devem ser sempre sistemáticas, apuradas e, baseadas em evidências.

\subsection{Considerações finais}

O capítulo tratou da abordagem metodológica que utilizamos para a avaliação de impacto das recomendações das MOEs nas eleições realizadas no Haiti e México, com o fim da Guerra Fria, dentro da Terceira Onda.

Embora localizados no paradigma de transição, ambos os casos conservam características de períodos autoritários anteriores, tendo o Haiti permanecido por muito tempo sob a suserania da família Duvalier, ao passo que o México esteve sob a liderança do PRI por cerca de setenta anos.

A própria abertura dos países à chegada das MOEls foi uma sinalização ao meio internacional que os presidentes Trouillot e Salinas, estavam dispostos a cumprir com uma série de normas internacionais de democracia, a exemplo da promoção da boa governança eleitoral. A boa governança eleitoral foi, inclusive, uma condicionalidade imposta para o recebimento de recursos, pelas agências de financiamento internacional, para os países em questão.

Dessa forma, apresentamos as principais organizações internacionais que enviaram missões a convite dos governantes do Haiti e México, e que disponibilizaram seus relatórios para consulta pública.

Embora tenham se multiplicado as missões de observação, ao pensarmos na presença de watchdogs como uma parte fundamental dos processos eleitorais realizados nos últimos vinte e cinco anos, nos indagamos sobre seu impacto nos critérios que eles se propõem a observar. De modo a responder essa pergunta, criamos índices de boa governança eleitoral e de impacto das missões sobre a governança eleitoral para avaliá-los. 


\section{LONGA TRADIÇÃO, POUCA EFICIÊNCIA: IMPACTO DAS MISSÕES DE OBSERVAÇÃO ELEITORAL NO PROCESSO ELEITORAL DO HAITI}

\subsection{Introdução}

O Haiti foi o primeiro país soberano a receber uma missão de observação internacional de eleições. Desde 1990, a presença de observadores estrangeiros tem sido algo constante e, até mesmo, solicitada pelos governantes. Isso se deve a características sociais, políticas e econômicas do país, que o tornam mais suscetível à influência externa.

Pastor (1998) defende que a presença e as ações de grupos internacionais têm ajudado várias vezes a salvar eleições, que de outra forma teriam falhas irremediáveis. Esse foi o caso, por exemplo, da Nicarágua e Haiti em 1990, na Guiana em 1992 e da República Dominicana quatro anos mais tarde. Mesmo em vários casos fracassados, os observadores internacionais desempenharam um papel útil, que foi o de negar legitimidade a governos eleitorais autoritários, tornando-os mais vulneráveis à pressão doméstica e internacional (idem).

Segundo Kelley (2009), os últimos anos viram surgir um mercado de observação internacional de eleições, consoante a demanda de governos ilegítimos, que buscavam reconhecimento no cenário internacional, em troca de benefícios econômicos, de agências de financiamento pró-democracia.

Os governos haitianos também têm mantido esse tipo de relacionamento com as agências citadas. Sua economia é fortemente dependente de ajuda externa e suas eleições contam com uma grande quantidade de missões de observação eleitorais, de forma a legitimar seus resultados finais.

Dessa forma, este capítulo explora inicialmente os atributos que tornam este país tão dependente de aprovação no cenário internacional, a ponto de até mesmo seus processos domésticos serem alvo de interferência externa. Em seguida realizamos a análise dos resultados obtidos com o índice de boa 
governança eleitoral, de forma a identificar o impacto da observação, assim como, das recomendações. Essa análise é importante porque permite explicar o longo relacionamento entre os observadores internacionais e as eleições haitianas e mostra como a prática se tornou essencial, já que a não participação de estrangeiros poderia acarretar em processos eleitorais com menor qualidade.

\subsection{Observadores nas eleições haitianas: convidar ou não?}

Os processos eleitorais no Haiti contam ainda com uma série de aspectos a serem melhorados, mesmo após as recomendações de organizações internacionais de monitoramento eleitoral. É de se questionar a eficiência dessas organizações em fazer com que suas recomendações sejam acolhidas pelo governo que as convida.

Segundo Kelley (2009), o convite à observação é sempre uma forma de acordo que dá às organizações o benefício de acesso a centros de votação, políticos locais e documentos, tais como a lista de registro dos votantes, que eles não conseguiriam de outra forma. Essas organizações são independentes, e, muitas vezes, divergem na forma como avaliam uma eleição. Porém, "organizações de monitoramento têm considerável influência e (...) suas avaliações influenciam a percepção dos governos sobre suas legitimidades" (idem, p. 59; Hyde, Kelley e Nielsen, 2016).

Quando há consenso em suas avaliações, aumenta a pressão para que o governo aceite as críticas, tornando mais difícil deslegitimar as declarações. Da mesma forma, "a comunidade internacional junto aos atores domésticos podem impulsionar reformas no governo" (Kelley, 2009, p. 61).

Para Hyde (2007), a credibilidade das missões deriva do fato de que outros atores percebem os relatórios divulgados como algo preciso, embora seja difícil classificar uma eleição como fraudulenta ou imprecisa, sobretudo, porque muitas das decisões das missões de condenar uma eleição, têm influência de variáveis políticas (Kelley, 2009). Na maioria das vezes, "observadores internacionais apontam alguns problemas no processo eleitoral e destacam áreas que devem ser melhoradas no futuro, mas dão seu apoio geral às eleições" (Hyde, 2007, p. 5). 
Ainda que Hartlyn e McCoy (2009) vejam poucas evidências de que a realização sucessiva de eleições, em democracias eleitorais, leve à sua mudança rumo à democracia liberal, muitos dos países, a exemplo do Haiti, tem apostado nisso, como uma etapa em um caminho para a mudança.

A incorporação de ideias democráticas em regimes mais novos tem aumentado nos últimos anos, como o demonstra o uso de suas premissas como base para a boa governança. De forma a continuar recebendo financiamentos externos, muitos das democracias eleitorais tendem a imitar práticas existentes em democracias consolidadas. Por isso, mesmo países em regimes mais fechados tendem a realizar eleições na tentativa de sinalizar para a comunidade internacional que têm cumprido com normas internacionais de boa governança (Hyde, 2006; Kelley, 2008).

O'Donnell, Schmitter e Whitehead (1986) tomam as transições da América Latina e do Sul da Europa e consideram as eleições fundacionais como o início do processo de consolidação de novos regimes. No entanto, para Lindberg (2006) as eleições têm pouco a ver com as transições, exceto como um indicador de sua conclusão bem-sucedida.

Vários autores enfatizam uma associação causal entre eleições e democratização. Para Schedler (2002), não existem eleições fundacionais, mas transicionais, indicando que os países estariam no caminho para a democracia, mas não seriam, ainda, democráticos. Em estudo dos países da América Central, Seligson e Booth (1995) argumentam que as eleições promovem a democracia de várias maneiras, em especial ao abrir o espaço político aos cidadãos, que passaram a buscar seus interesses juntos aos governantes e autoridades locais e, com efeito, expandiram suas liberdades civis. Desse ponto de vista, as eleições se tornaram tanto uma causa quanto uma espécie de plataforma para a participação política.

No Haiti, o que se viu antes e após a chegada dos observadores internacionais foi uma maior garantia da existência de competição política no país. Com algum retrocesso no ano de 1995, a competição se manteve nos últimos anos, ainda que muitas das eleições tenham sido marcadas por altos índices de concentração de voto em um só candidato, ou mesmo, denúncias de beneficiamento de um ou outro partido. 
Embora tumultuadas, as eleições têm ocorrido com relativa frequência, com forte presença de observadores, que se revezam na tarefa de monitorar todas as etapas do processo eleitoral no país.

Estudo de Kelley (2009) aponta que a participação de missões nas eleições se mostraram pouco efetivas no Haiti e em outros países em desenvolvimento como Angola e Camboja. Segundo a autora, apesar dos esforços de tornar as missões mais profissionais, abandonando o viés diplomático, os observadores não representam uma força muito grande para impulsionar mudanças. Na maioria das vezes, isso decorre do fato de que as missões não contam com recursos suficientes para monitorar todas as etapas e locais do processo eleitoral (Kelley, 2012).

A autora argumenta ainda que da mesma forma que é difícil para os atores internacionais impulsionar reformas, "os políticos tendem a ser particularmente relutantes em melhorar suas condutas com relação às eleições, porque isso tem implicações diretas em sua capacidade governativa" (idem, p. 98).

Segundo Hyde (2007), de uma forma geral a observação internacional tem impacto, principalmente, no dia da eleição. A presença dos observadores nos centros eleitorais, contribui para tentativas de manipulação de votos, a exemplo do depósito de cédulas já preenchidas

Ichino e Schundeln (2008), concordam com a autora e também indicam impactos para o dia da eleição, como o aumento no número de registro de eleitores em áreas com monitores internacionais. Para os autores, os partidos tendem a querer inflar o número de votos em seus candidatos aumentando o número de votos, através dos registros eleitores, no entanto, eles não desejam ser pegos fazendo isso. "Como consequência, os observadores poderiam, de fato, impedir agentes de partidos de montar esquemas fraudulentos de registro de eleitores nos centros eleitorais que eles visitam" (idem, p. 295).

Segundo Kelley (2012), "os monitores aumentam os custos relacionados à fraude e aumentam os benefícios atribuídos ao correto andamento das eleições" (p. 99). A expectativa com a observação é que ela diminua a probabilidade de fraude, dotando as eleições de maior qualidade (idem).

Da mesma forma, há a questão da legitimidade do governo, que, caso não fizesse 0 convite à observação internacional, seria automaticamente considerado um país não democrático, visto a recente emergência da Norma de 
Monitoramento Internacional (IEM) ${ }^{60}$. Entre os países que não realizam eleições competitivas e que não convidam observadores, podem ser citados os casos de Omã, Cuba, Síria, Turcomenistão, Uzbequistão e Vietnã. Em outras palavras, significa dizer que em comparação com a quantidade de países com eleições competitivas e observadores internacionais, a lista é muito menor (Hyde, 2006) ${ }^{61}$.

Assim, para o país mais pobre das Américas e extremamente dependente de ajuda externa, ser considerado antidemocrático acarretaria um prejuízo muito grande para seu desenvolvimento.

A realização de eleições com a presença de observadores internacionais é uma confirmação às agências de financiamento externas que um país cumpre com normas democráticas e, portanto, está apto a receber auxílio. Assim, são maiores as consequências para os governos que tentam manipular as eleições, que para aqueles atendem as normas democráticas (Hyde, 2006; Hoyos, 2014; Schedler, 2002b).

Segundo Kelley (2012), os observadores impactam na mudança de comportamento dos governantes mediante sua constante presença, reforçando normas internacionais. A autora argumenta que "avanços acarretados através da socialização, são possivelmente melhor materializados somente se os monitores participarem de uma série de eleições no país e repetidamente interagir e oferecer conselhos" (p. 99). Nesses casos, os monitores podem sugerir ou mesmo auxiliar a implementação de mudanças específicas.

De uma forma geral, a atuação dos observadores não impacta no universo global do processo eleitoral, no entanto, considerando que sua ausência poderia incorrer em prejuízos ao governo haitiano, ela se mostra como uma prática que ao longo das últimas eleições se tornou essencial. Da mesma forma, ações pontuais impulsionadas pelos observadores foram implementadas, ainda que de forma tímida, dentro da estrutura de governança eleitoral do Haiti.

Kelley (2012) afirma que é mais difícil avaliar, o quanto as melhorias experimentadas com a presença de observadores se mantêm ao longo do

\footnotetext{
$60 \mathrm{O}$ argumento de que um país não é democrático foi utilizado pelos Estados Unidos, em 2009, durante as eleições iranianas, conforme uma série de reportagens e documentos oficiais do governo estadunidense.

${ }^{61}$ Mais países tem convidado observadores para suas eleições, mesmo aqueles considerados democracias desenvolvidas como Estados Unidos, Canadá, Bélgica e alguns países europeus.
} 
tempo. Segundo a autora, é necessário adotar uma visão de longo prazo, que dê conta de uma série de eleições, primeiro, porque o monitoramento internacional acontece de forma regular e dificilmente há apenas uma experiência desse tipo. Segundo, a maioria dos esforços de observação tem como objetivo não somente diluir fraudes no dia das eleições, mas, principalmente, trazer mudanças no longo prazo.

Em se tratando de eleições fundacionais há maior preocupação de um governo em mostrar que ele cumpre com uma série de normas internacionais democráticas (Leduc, Niemi e Norris, 2014; Norris, 2013a). No caso haitiano, o convite à observação esteve desde o início intimamente ligado à sua dependência de recursos externos, de fontes promotoras da democracia.

Como demonstra Kelley (2008), com o fim da Guerra Fria havia acabado também o sistema de patronagem através do qual os grandes poderes distribuíam recursos com vistas à manutenção de seus aliados, em que muitos dos países sobreviveram se alinhando a apenas um dos lados. A democracia e boa governança passaram a ser critérios fundamentais na escolha dos países estratégicos que deveriam receber ajuda financeira internacional e também política. A comunidade de doadores internacionais, aí incluído o Banco Mundial, passaram a fortalecer a democracia, como uma condição para o envio de recursos, sendo o convite à observação internacional um dos requisitos para o recebimento desses benefícios, pelos governos nacionais (idem).

Não obstante, o longo relacionamento de um país com as MOEls não significa necessariamente que um país não conseguiu melhorar a qualidade de suas eleições, ou o contrário, que ele melhorou tanto a ponto de a observação ter se tornado uma parte da alegoria eleitoral. Kelley (2012) argumenta que cada caso deve ser analisado de forma individual, visto que a qualidade das eleições pode não ter melhorado de um modo geral, mas que a observação pode ter contribuído para o sucesso de aspectos pontuais. Ela cita o caso do Quênia, alterou a forma como sua contagem era realizada após recomendações de observadores; a Rússia realizou várias reformas para dar maior transparência ao processo, enquanto a Nicarágua fez várias mudanças administrativas e logísticas (idem). 
Passamos assim, a caracterização do Haiti a partir de seus aspectos socioeconômicos e políticos, que ajudam na explicação da grande participação de organizações de monitoramento internacional em suas eleições.

\subsection{Caracterização do Haiti segundo aspectos socioeconômicos e políticos}

O processo de democratização do Haiti envolveu a participação tanto de instituições locais, como de atores internacionais. Em início dos anos 1990, o país experimentou sua transição para um regime democrático formal, mas a consolidação democrática tem seguido um caminho turbulento ${ }^{62}$.

Não somente na política, como também na economia há forte componente estrangeiro presente. O país é o mais pobre do hemisfério ocidental (Pnud, 2015), e extremamente dependente de ajuda econômica externa, sobretudo de organizações que apoiam a democracia, a exemplo da ONU. Leininger (2010), defende que a dependência de ajuda econômica externa em si não é o problema. Para a autora, a dependência se torna um problema, quando ela gera a necessidade de mais e mais auxílio e os auxílios deixam de ter eficiência, como tem se configurado na situação haitiana.

A maioria da população haitiana não tem acesso a serviços públicos como saúde e energia elétrica. O Índice de Desenvolvimento Humano (IDH) do Haiti, em 2014 era de 0.483 , o que o coloca entre os países com menor desenvolvimento humano, valor próximo ao de países como Ruanda e Uganda e bem abaixo da média do Caribe e América Latina, de 0.748 (Pnud, 2016).

Tabela 6 - IDH* do Haiti, 1990 a 2015

\begin{tabular}{ccc}
\hline País & Ano & IDH \\
\hline & 1990 & 0.417 \\
& 1995 & 0.422 \\
Haiti & 2000 & 0.442 \\
& 2005 & 0.455 \\
& 2010 & 0.471 \\
& 2011 & 0.475 \\
& 2012 & 0.479 \\
& 2013 & 0.481 \\
& 2014 & 0.483 \\
\hline
\end{tabular}

62 Do ponto de vista das transições apresentadas por Huntington (1994), o Haiti seria um país que promoveu a liberalização, sem, no entanto, ter de fato, consolidado sua democratização. 


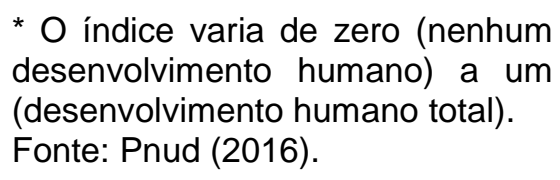

A criminalidade cresceu em função da ineficiência de um sistema de segurança público e, mais de 45 mil funcionários públicos são mal pagos, ou não chegam nem a receber salário. "Em conjunto, no contexto de tais situações frágeis do Estado, o fracasso do Haiti em consolidar ou aprofundar o regime democrático formal é pouco surpreendente" (Leininger, 2010, p. 69).

O último Índice sobre Estados Frágeis $(\mathrm{FSI})^{63}$, realizado em 2016, mostrou o país na última posição do ranking da Américas. Ele aparece também no ranking dos dez países mais frágeis do mundo, junto a Somália, Sudão do Sul, Afeganistão e outros.

O índice analisa uma série de indicadores que podem contribuir para a maior ou menor estabilidade de um país. No caso haitiano, ao se considerar os últimos anos em que o índice foi feito - a partir de 2005 -, o país foi classificado como um dos dez mais frágeis, em todos os índices divulgados ${ }^{64}$ (FSI, 2016).

Não somente isso, como o Haiti também foi classificado pelo índice como extremamente vulnerável, devido, ao agravamento das condições humanas e enfraquecimento do Estado ao longo dos anos. Poucos são os países que se encaixam nessa categoria (idem). Para Gauthier e Moita (2010, p. 1), "o Haiti é um exemplo clássico de um estado frágil que tem sido descrito como 'à beira de se tornar um Estado permanentemente falido"'.

Segundo Leininger (2010), quanto maior a vulnerabilidade de um Estado, maior será a potencial influência de doadores internacionais nos processos políticos do país, tal qual tem se configurado a situação haitiana (idem). Sem esse envolvimento, no entanto, em outras áreas como a segurança, o país

\footnotetext{
$63 \mathrm{Um}$ estado frágil é aquele que nos quais as lideranças possuem pouca vontade política e as estruturas estatais têm pouca capacidade de garantir as funções básicas para redução da pobreza, promover o desenvolvimento e a salvaguarda dos direitos humanos e de sua população (FSI, 2016; OCDE, 2007).

$64 \mathrm{O}$ índice agrega dentro de cada um dos indicadores as pressões exercidas sobre cada uma das áreas de estudo e as medidas tomadas. Por exemplo, no caso da legitimidade do Estado, foram incluídos níveis de corrupção, participação política, processos eleitorais, nível democrático, entre outros e as medidas tomadas pelo Estado, para resolver ou melhorar um determinado quesito.
} 
poderia retornar a um conflito violento, a exemplo do apoio prestado pela Missão das Nações Unidas para Estabilização do Haiti (Minustah), nessa área.

Gauthier e Moita (2010) concordam em parte com a autora na questão das intervenções externas, programas econômicos internacionais e ajuda bilateral, dizendo que elas também tiveram efeitos negativos, além dos efeitos positivos. Os autores defendem que essas intervenções internacionais tiveram efeitos negativos, sobretudo nas relações Estado-sociedade. Mas discordam sobre a questão da segurança, porque segundo elas a presença da Minustah, desde 1994, "trouxe algumas melhorias ao Haiti sob a perspectiva de paz democrática liberal, ajudando, por exemplo, na organização de eleições livres e justas" (idem, p. 8).

As operações lideradas pela missão de paz da Minustah dissolveram algumas das gangues armadas nas favelas das cidades do Haiti, mas a segurança e a estabilidade estão longe de se consolidar. Novas ameaças estão aparecendo. Os crimes mais graves persistem, especialmente o sequestro e o tráfico de drogas, e não há uma força policial suficientemente ampla e operacional, nem sistemas judiciais e penitenciários funcionais. A maior deficiência em segurança se mostra, portanto, maior no plano institucional e organizacional.

Sobre a questão econômica ainda, as autoras argumentam que os Pequenos Estados Insulares em Desenvolvimento (SIDS) tendem a sofrer maior vulnerabilidade econômica que outros grupos de países com maior diversificação. O Haiti apresenta algumas das características dessas SIDS, como: economia amplamente influenciada por forças externas - similar àquelas de países exportadores de petróleo -, grande grau de abertura e concentração de exportações e dependente de importações estratégicas. Porém, a ilha não é um exemplo clássico de SIDS, uma vez que sua população é relativamente grande, se comparada a dos demais membros do grupo 65 .

65 O grupo dos SIDS foi reconhecido internacionalmente, pela primeira vez, como um grupo diferenciado de países em desenvolvimento, durante a Conferência das Nações Unidas sobre Meio Ambiente e Desenvolvimento, em junho de 1992, no Rio de Janeiro, Brasil. O grupo conta com membros no Caribe, Pacífico, África, Oceano Índico, Mediterrâneo e Mar do Sul da China. 
O país é também um dos mais vulneráveis a desastres naturais ${ }^{66}$, devido, principalmente, sua localização geográfica, que o coloca no caminho dos furacões do Atlântico e sobre a placa tectônica do Caribe. A combinação de extremo desmatamento com erosão do solo, gera constantes deslizamentos de terra oriundas das montanhas, além de inundações que, frequentemente, deixam as cidades com muita lama (Gauthier e Moita, 2010).

As tensões migratórias com a República Dominicana também têm escalado e se tornaram um potencial foco de conflitos $^{67}$. Em 2009, o governo dominicano decidiu alterar a lei de nacionalidade, negando o status de cidadão a pessoas de ascendência haitiana, nascidas em território nacional (Conflict Barometer, 2016). "A decisão deixou, segundo os números do Alto Comissariado das Nações Unidas para Refugiados, 2000.000 apátridas, sob o risco de deportação" (idem). Como consequência, o número de imigrantes ilegais aumentou, dificultando as relações diplomáticas entre as duas nações. Em fevereiro do mesmo ano, residentes da cidade de Santiago, na República Dominicana, incendiaram uma bandeira do Haiti, como forma de protesto contra a presença de haitianos imigrantes na área (ibidem).

Em 2015, outro episódio intensificou a tensão entre os países. O anúncio dos resultados finais das eleições presidenciais, em outubro, gerou uma onda de violência nas principais cidades haitianas, por parte de cidadãos insatisfeitos, que acusavam o governo de ter fraudado o processo eleitoral. Com receio de que muitos haitianos saíssem do país, em busca de um local mais seguro, as fronteiras da República Dominicana foram fechadas.

Destarte as ameaças do exterior, o plano doméstico também apresenta alguns desafios à estabilidade do país. A acentuação da deterioração socioeconômica em que mais de $50 \%$ da população se encontra abaixo da linha

\footnotetext{
66 Segundo a Estratégia Internacional das Nações Unidas para a Redução de Desastres (UNISDR, 2004), a vulnerabilidade engloba as condições determinadas pelos fatores ou processos físicos, sociais, econômicos e ambientais, que aumentem a susceptibilidade de uma população ao impacto de perigos.

${ }^{67}$ Embora o conflito tenha escalado de forma mais intensa nos últimos anos, ele tem início ainda em 1977, quando forte crise econômica abateu o país, diminuindo o poder de compra dos haitianos e aumentando a fome. Muitos deles fugiram para os Estados Unidos e Cuba, enquanto que alguns se entregaram ao trabalho, em condições análogas à de escravidão, nas plantações de açúcar da República Dominicana. A imigração se intensificou e a estimativa é que entre os anos 1990 e 2000, 320 mil haitianos tenham imigrado para o outro lado da ilha (Latinoamericana, 2007).
} 
de pobreza, somados à baixa esperança de vida e alta taxa de analfabetismo, são só alguns deles.

Por fim, são vários os desafios a serem enfrentados pelos governos haitianos, sendo as eleições uma parte importante deles. Tanto no passado, quanto mais recentemente, o que se vê são irregularidades, a exemplo do difícil acesso dos eleitores aos centros de votação ou mesmo, a pouca segurança dos eleitores ao votar. No entanto, antes de discutir questões mais contemporâneas, se mostra necessário fazer uma retrospectiva das eleições que antecederam a democratização do pais, tema do próximo tópico.

\subsubsection{Antecedentes das eleições fundacionais de 1990}

Silvayn (2013) descreve a situação política haitiana ainda na era Duvalier como a de um sistema clientelista, mais que um regime autoritário apenas. Essa caracterização da situação política haitiana em um sistema clientelista se deve, sobretudo, à ascensão do grupo dos Tonton Macoutes, o exército pessoal de Duvalier pai, que em meados de 1986 já atingia a marca de trinta e seis mil recrutados. O discurso de Duvalier, no entanto, era o de que o exército agia de maneira independente, sendo leais ao governante.

Para o autor:

"Em essência, a atividade política era vista como algo que só poucos escolhidos poderiam participar, com François Duvalier (e mais tarde seu filho) como o guardião supremo e pai patriarcal da nação. Os camponeses e os pobres urbanos eram tratados como sujeitos ao Estado e foram, portanto, excluídos como participantes do discurso de construção da nação e igualdade. No Estado 'macoutizado' de Duvalier, como em uma família tradicional, os 'filhos' ou seus cidadãos eram considerados incapazes de tomar decisões complexas; apenas o pai era considerado competente o suficiente para decidir. Qualquer um que ousasse redefinir as esferas públicas ou privadas foi sistematicamente reprimido" (Silvayn, 2013, p. 65).

Ademais,

"O estado macoutizado transformou a nação em uma entidade obediente, não-pluralista, onde a ação política dependia apenas das bênçãos do executivo supremo. No estado de macoutizado de Duvalier, o clientelismo político e o uso sistemático da força bruta foram os instrumentos mais eficazes na criação de uma fonte do poder do 
Estado da qual não se podia escapar, apreendendo qualquer e todo desafio a sua legitimidade" (Silvayn, 2013, p. 79-80)68.

É somente após a morte de Duvalier pai e a saída de Duvalier filho da liderança do país, que tem início uma série de mudanças na configuração política do país, ainda que, com características do regime anterior. Dash (2013) cita a tomada das ruas por manifestantes com a destruição da sede principal dos Tonton Macoutes, além das residências dos Duvaliers. Para o autor, a destruição dos traços físicos do duvalierismo não garantiu o fim da política do antigo regime, sendo que, na verdade, o que se viu foi a divisão dos haitianos entre patriotas e antipatriotas, autênticos e bovaristas.

Com a saída da família Duvalier restaram os antigos funcionários do regime que perpetuaram as mesmas práticas antes empregadas durante 0 período autoritário. Comandantes militares se tornaram força mercenária, enquanto que seus escalões inferiores, em especial, a polícia rural e os chefes de seção, se beneficiaram através da extorsão e terror contra a população (idem).

Em 1985, quatro estudantes foram mortos pelos Tonton Macoutes durante um protesto contra o governo transitório em Gonaïves, quarta maior cidade do país. Os protestos aumentaram ao longo dos meses, a ponto de a República Dominicana fechar suas fronteiras com o país vizinho e aumentar seu contingente militar na linha de fronteira (Keesing's, 01/01/1986).

No ano seguinte uma greve geral paralisa grande parte de Porto Príncipe, "acompanhada de numerosas demonstrações de apoio a realização de eleições livres, nas quais ao menos duas pessoas foram mortas pelas tropas duvalistas" (idem, s.p.). Muitos impedimentos à organização popular foram derrubados, gerando a rápida proliferação de grupos de oposição ao governo, ou seja, "mais de sessenta partidos políticos foram criados e algumas centenas de grupos de pressão, religiosos e do trabalho foram estabelecidos" (ibidem, s.p.).

A maior coordenação entre as novas organizações políticas levou à criação de um Congresso Nacional de Movimentos Democráticos (NCDM), em oposição ao governo militar. Entre os objetivos do novo movimento estava o de assegurar direitos democráticos integrais, que começaram a se realizar com o esboço da nova constituição, em 1987, que foi a referendo popular

${ }^{68}$ Cf. Nicholls (1998). 
posteriormente. Assim, "de fevereiro de 1986 a setembro de 1991, o Haiti havia se tornado um vasto laboratório aberto à participação popular democrática" (Dupuy, 2013, p. 59).

Em 1987 o massacre de 34 cidadãos pelos militares adiou as eleições gerais pela primeira vez e, em 1988, Leslie Manigat assume a liderança do país, em um processo eleitoral manipulado por uma junta militar. Em março de 1990, a ministra de Justiça Ertha Pascal Trouillot assumiu a presidência com 0 compromisso de realizar eleições livres proximamente.

Betts e Huntington (1986), acreditam que a instabilidade no Haiti na Terceira Onda poderia ser resultado não somente da morte de Papa Doc, mas de sua própria permanência à frente do país por tantos anos ${ }^{69}$.

No caso do Haiti, entretanto, o que decorreu após a morte de Papa Doc, na liderança do país por 14 anos, não passou de uma instabilidade moderada, com baixo nível de organização social e pouco desenvolvimento econômico, situação não muito diferente daquela observada nos anos em que ele governara (ibidem). No entanto, inovações como a realização do referendo constitucional ${ }^{70}$ em 1987, contribuíram para que três anos depois fossem realizadas eleições no país, com vistas a superação dessa situação histórica de instabilidade política. O referendo, por sua vez, foi observado por uma série de organizações de direitos humanos e teve ausência de sigilo do voto em pelo menos um distrito de votação.

\begin{abstract}
"Em muitos dos centros de votação de Cap Haitien os eleitores não puderam votar secretamente, aparentemente porque os envelopes em que as cédulas seriam colocadas antes de serem inseridas nas urnas, não haviam sido entregues. Mesmo onde havia envelopes, os eleitores, por vezes, depositavam as cédulas publicamente, ainda que essa prática não fosse algo da conivência do governo. Os observadores que notaram tal prática relataram, entretanto, que nenhum dos eleitores criticou o fato de que o segredo do voto não havia sido garantido" (Reisman, 1992, p. 41).
\end{abstract}

Uma delegação de cinco representantes da missão conjunta do NDI e IRI (na época denominado Instituto Nacional Republicano para Assuntos

\footnotetext{
69 O Haiti figura como um dos casos analisados pelos autores no artigo, após a morte de François Duvalier (Papa Doc), em 1971, e transferência de poder a seu filho Jean-Claude Duvalier (Baby Doc).

70 No Referendo para a Ratificação da Constituição do Haiti de 1987 foram utilizadas cédulas de votação coloridas para superar o problema do analfabetismo e mais de $50 \%$ do eleitorado participou do pleito (Keesing's, 02/01/1988).
} 
Internacionais (NRIIA)) observou o referendo e também o desenvolvimento organizacional dos vários partidos políticos no país.

Em seu relatório final, as organizações apontaram uma série de recomendações para as eleições locais e nacionais marcadas para julho e novembro daquele ano. Entre as mudanças que deveriam ser realizadas estavam a garantia do voto secreto, que não havia sido respeitada no referendo; a criação de um programa de educação dos eleitores, além de intenso treinamento dos funcionários eleitorais.

Algumas mudanças começaram a operar no país, tal como a maior participação de cidadãos em processos eleitorais. Os observadores da missão conjunta relatam que "durante a era Duvalier, os haitianos passavam os dias de eleição em suas casas e as ruas ficavam desertas. Para o referendo, no entanto, as ruas estavam cheias ao longo de todo o dia" (NDI e NRIIA, 1987, p. 8).

Não somente o referendo foi de grande importância para a redução na instabilidade política do país, como "as eleições futuras promoviam uma oportunidade de estabelecer o princípio das eleições livres e justas, ou os próximos grandes passos rumo à democracia" (idem, p. 14). Além disso, "todos os setores da sociedade haitiana viam o estabelecimento de uma política democrática como o mecanismo mais apropriado para lidar com a grande gama de problemas do país" (ibidem, p. 16).

Como se pode observar, a atmosfera que antecedeu a realização das primeiras eleições no país, após a morte de Papa Doc, era de entusiasmo, mesmo com o impacto moderado da morte do ex-presidente haitiano na política local.

Vale mencionar que a presença de observadores internacionais é constante desde antes das eleições fundacionais. Em janeiro 1990, o cenário era de aprofundamento da crise política, que colocava de um lado a presidente Pascal-Trouillot e o do outro o Conselho de Estado. Como resultado, ocorreu o adiamento das eleições conjuntamente, que estava marcada para ocorrer no início do ano, ao mesmo tempo em que aumentava a pressão política exercida pela oposição, que defendia a legitimidade do adiamento do processo eleitoral, visto que que o governo não poderia assegurar a segurança dos eleitores, funcionários e demais envolvidos na condução das eleições, em virtude do clima de violência e ilegalidade dentro do país (Keesing's, 09/01/1990). 
Mesmo assim, em dezembro de 1990, ocorreram eleições presidenciais, nas quais Jean-Bertrand Aristide, representante da Frente Nacional para Democracia e Mudança, derrotou outros dez candidatos.

Conforme Dupuy (2013), assim que assumiu o poder, em fevereiro de 1991, Aristide tentou atender as amplas demandas da população, como melhores condições de trabalho, um salário mínimo mais elevado, menos corrupção na administração pública, maior acesso à educação, campanha de alfabetização etc. No entanto, essa breve experiência em democracia teve um fim abrupto em setembro de 1991. As classes dominantes e os militares se sentiram ameaçados não só pelas reformas propostas, mas também pela vasta mobilização popular que pressionava pela sua aprovação.

Ao longo dos anos 1990, os haitianos viveram entre uma série de governos que foram derrubados por golpes militares, mesmo assim, as eleições têm se mantido constantes. Da mesma forma, a observação das eleições por estrangeiros se consolidou como uma prática, que, atualmente, é fundamental para legitimar a imagem internacional do Haiti como uma país minimamente democrático.

\subsection{Primeiras análises: observação desde as eleições fundacionais}

Como é possível observar o Haiti tem passado por uma série de idas e vindas quanto a sua caracterização como um regime democrático, isto é, como democracia eleitoral. Conforme definição mínima de Dahl (2005), as eleições exercem papel central para que um país seja considerado democrático, sendo que, essa regra, no entanto, pode levar à falácia do eleitoralismo (Schmitter e Karl, 1991).

Conscientes de que as eleições não definem totalmente uma democracia, mas que são parte fundamental desta e que os observadores estão encarregados de avaliar se uma eleição teve sua realização conforme critérios internacionais democráticos ou não, oferecemos algumas interpretações para a atuação de estrangeiros em território haitiano, ao longo de seus dezenove processos eleitorais, nos últimos vinte e cinco anos.

Quanto à sua atuação, vimos que as missões enviadas ao Haiti são, em geral, bem diversificadas quanto à sua composição e em grande número. No 
entanto, os relatórios apresentam conclusões bem parecidas quanto aos pontos que merecem atenção ao longo do processo eleitoral e, que, depois, serão alvo das recomendações.

De um modo geral, a avaliação de governança eleitoral ao longo do processo eleitoral foi baixo com pequena diferença no índice entre as fases de observação, conforme apresentado no quadro abaixo, e nas tabelas em sequência:

\section{Quadro 5 - Índice de Governança Eleitoral, por fase de observação, Haiti}

\begin{tabular}{ccc}
\hline País & Fase & Índice \\
\hline \multirow{3}{*}{ Haiti } & Pré-eleitoral & $0.36 \rightarrow$ Baixo \\
& Dia da eleição & $0.39 \rightarrow$ Baixo \\
& Pós-eleitoral & $0.32 \rightarrow$ Baixo \\
\hline
\end{tabular}


Tabela 7 - Matriz de observação para o período pré-eleitoral, Haiti

\begin{tabular}{|c|c|c|c|c|c|c|c|c|c|c|c|c|c|c|c|c|c|c|c|c|}
\hline Indicadores/Anos & $\frac{\stackrel{8}{\circ}}{\frac{8}{2}}$ & 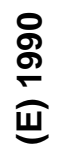 & $\begin{array}{l}\frac{5}{\sigma} \\
\text { 戸 }\end{array}$ & $\begin{array}{l}\stackrel{\text { g }}{g} \\
\stackrel{7}{\beth}\end{array}$ & $\begin{array}{l}\text { م } \\
\stackrel{g}{=} \\
\text { 己 }\end{array}$ & 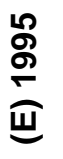 & 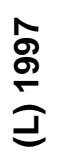 & $\begin{array}{l}\text { 옹 } \\
\text { 군 }\end{array}$ & $\begin{array}{l}\text { 옹 } \\
\text { 길 }\end{array}$ & $\begin{array}{l}\text { ᄋ } \\
\text { ণ } \\
\text { జు }\end{array}$ & 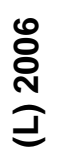 & $\begin{array}{l}\stackrel{8}{0} \\
\text { ํ. } \\
\text { 己 }\end{array}$ & 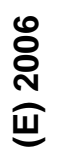 & $\begin{array}{l}\text { 응 } \\
\text { ำ } \\
\text { 己 }\end{array}$ & 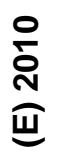 & 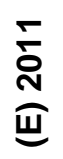 & $\frac{n}{\stackrel{n}{0}}$ & 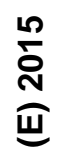 & $\begin{array}{l}\frac{n}{0} \\
\stackrel{N}{J} \\
\end{array}$ & Número de sim \\
\hline $\begin{array}{l}\text { Existência de um organismo eleitoral } \\
\text { independente }\end{array}$ & $\mathrm{n}$ & $\mathrm{n}$ & $\mathrm{n}$ & $\mathrm{n}$ & $\mathrm{n}$ & $\mathrm{n}$ & $\mathrm{n}$ & $\mathrm{n}$ & $\mathrm{n}$ & $\mathrm{n}$ & $\mathrm{n}$ & $\mathrm{n}$ & $\mathrm{n}$ & $\mathrm{n}$ & $\mathrm{n}$ & $\mathrm{n}$ & $\mathrm{n}$ & $\mathrm{n}$ & $\mathrm{n}$ & 0 \\
\hline Ausência de grupos armados & s & s & $\mathrm{n}$ & $\mathrm{n}$ & $\mathrm{n}$ & $n$ & $n$ & $\mathrm{n}$ & S & S & $n$ & $\mathrm{n}$ & $n$ & $\mathrm{n}$ & $n$ & $\mathrm{n}$ & $\mathrm{n}$ & s & s & 6 \\
\hline Respeito ao calendário eleitoral & s & s & s & $\mathrm{s}$ & s & S & s & $\mathrm{n}$ & $n$ & s & $n$ & $\mathrm{n}$ & $n$ & $\mathrm{n}$ & $\mathrm{n}$ & $n$ & s & $\mathrm{n}$ & s & 10 \\
\hline Fiscalização de financiamento ilegal de campanha & $\mathrm{n}$ & $\mathrm{n}$ & $\mathrm{n}$ & $\mathrm{n}$ & $\mathrm{n}$ & $\mathrm{n}$ & $\mathrm{n}$ & $\mathrm{n}$ & $\mathrm{n}$ & $\mathrm{n}$ & $n$ & $\mathrm{n}$ & $n$ & s & s & s & s & s & s & 6 \\
\hline Coordenação efetiva de centros eleitorais & $\mathrm{n}$ & $\mathrm{n}$ & $\mathrm{n}$ & $\mathrm{n}$ & $\mathrm{n}$ & $n$ & s & $\mathrm{n}$ & $n$ & $n$ & $n$ & $\mathrm{n}$ & $n$ & $\mathrm{n}$ & $n$ & $n$ & $\mathrm{n}$ & $\mathrm{n}$ & $\mathrm{n}$ & 1 \\
\hline Ausência de focos de violência eleitoral & $\mathrm{n}$ & $\mathrm{n}$ & $\mathrm{n}$ & $\mathrm{n}$ & $\mathrm{n}$ & $n$ & $\mathrm{n}$ & $\mathrm{n}$ & $\mathrm{n}$ & $n$ & s & $\mathrm{n}$ & $\mathrm{n}$ & $\mathrm{n}$ & $n$ & $\mathrm{n}$ & $\mathrm{s}$ & $\mathrm{n}$ & $\mathrm{n}$ & 2 \\
\hline Capacitação de oficiais eleitorais & $\mathrm{n}$ & $\mathrm{n}$ & $\mathrm{n}$ & s & $\mathrm{n}$ & s & s & $\mathrm{n}$ & s & s & s & s & s & $\mathrm{n}$ & $n$ & s & s & s & $n$ & 11 \\
\hline Educação cívica sobre importância do voto & $\mathrm{n}$ & $\mathrm{n}$ & $\mathrm{n}$ & s & $\mathrm{n}$ & s & $\mathrm{n}$ & $\mathrm{n}$ & $\mathrm{n}$ & s & s & $\mathrm{n}$ & $n$ & $\mathrm{n}$ & $n$ & s & s & s & s & 8 \\
\hline $\begin{array}{l}\text { Ausência de campanhas de desmobilização de } \\
\text { eleitores }\end{array}$ & $\mathrm{n}$ & $\mathrm{n}$ & $\mathrm{s}$ & $\mathrm{n}$ & $\mathrm{n}$ & $n$ & $n$ & $\mathrm{~s}$ & $n$ & $n$ & $S$ & $\mathrm{~s}$ & $S$ & $\mathrm{~s}$ & $S$ & $\mathrm{~s}$ & $\mathrm{n}$ & $\mathrm{n}$ & $\mathrm{n}$ & 8 \\
\hline Competição política & $\mathrm{s}$ & $\mathrm{s}$ & $\mathrm{s}$ & $s$ & $\mathrm{~s}$ & $S$ & $\mathrm{~s}$ & $\mathrm{~s}$ & $s$ & $S$ & $S$ & $\mathrm{~s}$ & $S$ & $\mathrm{~s}$ & $S$ & $\mathrm{~s}$ & $s$ & $S$ & S & 19 \\
\hline Fornecimento de credenciais aos eleitores & $\mathrm{n}$ & $\mathrm{n}$ & $\mathrm{n}$ & $\mathrm{n}$ & $\mathrm{n}$ & $n$ & $n$ & $\mathrm{~s}$ & $\mathrm{~s}$ & $S$ & s & $\mathrm{s}$ & $\mathrm{s}$ & $\mathrm{s}$ & $s$ & $\mathrm{~s}$ & $\mathrm{~s}$ & $\mathrm{~S}$ & $\mathrm{~S}$ & 12 \\
\hline Ausência de erros no registro de eleitores & $\mathrm{n}$ & $\mathrm{n}$ & $\mathrm{n}$ & $\mathrm{n}$ & $\mathrm{n}$ & $n$ & $n$ & s & $n$ & $n$ & $n$ & $\mathrm{n}$ & $n$ & $\mathrm{n}$ & $\mathrm{n}$ & $\mathrm{n}$ & $\mathrm{n}$ & $n$ & $\mathrm{n}$ & 1 \\
\hline $\mathrm{N}^{0} \operatorname{sim}$ & 3 & 3 & 3 & 4 & 2 & 4 & 4 & 4 & 4 & 6 & 6 & 4 & 4 & 4 & 4 & 6 & 7 & 6 & 6 & Total = 84 \\
\hline
\end{tabular}

Fonte: Relatórios das missões de observação eleitoral internacionais. Elaboração própria.

\section{Índice de governança eleitoral no dia da eleição $=0.36$}


Tabela 8 - Matriz de observação para o dia da eleição, Haiti

\begin{tabular}{|c|c|c|c|c|c|c|c|c|c|c|c|c|c|c|c|c|c|c|c|c|}
\hline Indicadores/Anos & $\begin{array}{l}\text { ㅇ } \\
\stackrel{\operatorname{g}}{=} \\
\text { 己 }\end{array}$ & 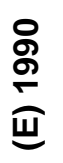 & $\begin{array}{l}\text { g } \\
\stackrel{\text { o }}{=} \\
\text { 己 }\end{array}$ & 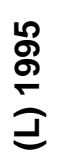 & 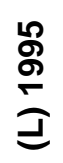 & 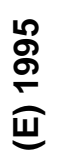 & 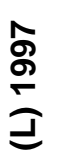 & $\begin{array}{l}\text { 응 } \\
\text { 에 } \\
\text { J }\end{array}$ & $\begin{array}{l}\stackrel{8}{\circ} \\
\text { 을 } \\
\text { 己. }\end{array}$ & $\begin{array}{l}\stackrel{8}{\circ} \\
\text { 을 } \\
\text { జు }\end{array}$ & $\begin{array}{l}\stackrel{\circ}{8} \\
\stackrel{\text { N }}{\text { 己. }}\end{array}$ & $\begin{array}{l}\text { ○ } \\
\stackrel{N}{N} \\
\text { J }\end{array}$ & 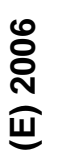 & 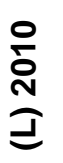 & 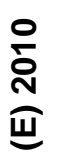 & $\begin{array}{l}\overline{\check{\delta}} \\
\text { జు }\end{array}$ & $\begin{array}{l}\text { no } \\
\stackrel{\text { N }}{\beth}\end{array}$ & 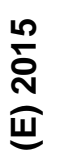 & 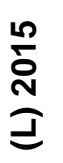 & Número de sim \\
\hline Ausência de erros nas listas eleitorais & $\mathrm{n}$ & $n$ & $\mathrm{n}$ & $\mathrm{n}$ & $\mathrm{n}$ & $n$ & $\mathrm{n}$ & $\mathrm{n}$ & $\mathrm{s}$ & $n$ & $\mathrm{n}$ & $\mathrm{n}$ & $n$ & $\mathrm{n}$ & $\mathrm{n}$ & $\mathrm{s}$ & $\mathrm{n}$ & $\mathrm{s}$ & s & 4 \\
\hline Garantia de segurança dos eleitores & $\mathrm{s}$ & $\mathrm{s}$ & $\mathrm{n}$ & $\mathrm{n}$ & $\mathrm{s}$ & $\mathrm{s}$ & $\mathrm{s}$ & $\mathrm{s}$ & $\mathrm{n}$ & $\mathrm{n}$ & $\mathrm{s}$ & $\mathrm{s}$ & $\mathrm{s}$ & $\mathrm{s}$ & $\mathrm{s}$ & $\mathrm{s}$ & $\mathrm{n}$ & $\mathrm{s}$ & $\mathrm{s}$ & 14 \\
\hline $\begin{array}{l}\text { Presença de material e membros eleitorais na abertura } \\
\text { dos centros }\end{array}$ & $\mathrm{n}$ & $\mathrm{s}$ & $\mathrm{n}$ & $\mathrm{n}$ & $\mathrm{n}$ & $\mathrm{n}$ & $\mathrm{n}$ & $\mathrm{n}$ & $\mathrm{s}$ & $\mathrm{n}$ & $\mathrm{n}$ & $\mathrm{s}$ & $\mathrm{s}$ & $\mathrm{n}$ & $\mathrm{n}$ & $\mathrm{s}$ & $\mathrm{n}$ & $\mathrm{s}$ & $\mathrm{s}$ & 7 \\
\hline Pontualidade na abertura dos centros de votação & $\mathrm{n}$ & $\mathrm{n}$ & $\mathrm{n}$ & $\mathrm{n}$ & $\mathrm{n}$ & $\mathrm{n}$ & $\mathrm{n}$ & $\mathrm{n}$ & $\mathrm{n}$ & $\mathrm{n}$ & $\mathrm{n}$ & $\mathrm{s}$ & $\mathrm{s}$ & $\mathrm{n}$ & $\mathrm{n}$ & $\mathrm{n}$ & $\mathrm{n}$ & $\mathrm{s}$ & $\mathrm{s}$ & 4 \\
\hline Fácil acesso dos eleitores aos centros de votação & $\mathrm{n}$ & $\mathrm{n}$ & $\mathrm{n}$ & $\mathrm{s}$ & $\mathrm{s}$ & $\mathrm{s}$ & $\mathrm{s}$ & $\mathrm{n}$ & $\mathrm{s}$ & s & $\mathrm{n}$ & $\mathrm{n}$ & $\mathrm{n}$ & s & s & $\mathrm{s}$ & $\mathrm{n}$ & s & $\mathrm{s}$ & 11 \\
\hline Mulheres e grupos minoritários presentes & $\mathrm{s}$ & s & $\mathrm{s}$ & $\mathrm{s}$ & $\mathrm{s}$ & $\mathrm{s}$ & $\mathrm{s}$ & $\mathrm{s}$ & $\mathrm{s}$ & $\mathrm{s}$ & $\mathrm{s}$ & $\mathrm{s}$ & $\mathrm{s}$ & $\mathrm{s}$ & $\mathrm{s}$ & $\mathrm{s}$ & $\mathrm{s}$ & $\mathrm{s}$ & $\mathrm{s}$ & 19 \\
\hline Eleitor informado sobre conteúdo do voto e como votar & $\mathrm{n}$ & $\mathrm{n}$ & $\mathrm{n}$ & $\mathrm{n}$ & $\mathrm{n}$ & $\mathrm{n}$ & $\mathrm{n}$ & $\mathrm{s}$ & $\mathrm{s}$ & $\mathrm{n}$ & $\mathrm{n}$ & $\mathrm{n}$ & $\mathrm{n}$ & $\mathrm{n}$ & $\mathrm{n}$ & s & $\mathrm{n}$ & $\mathrm{n}$ & $\mathrm{n}$ & 3 \\
\hline $\begin{array}{l}\text { Bom preenchimento das atas eleitorais (sem erros e } \\
\text { rasuras) }\end{array}$ & $\mathrm{s}$ & $\mathrm{s}$ & $\mathrm{n}$ & $\mathrm{s}$ & $\mathrm{s}$ & $\mathrm{s}$ & $\mathrm{n}$ & $\mathrm{n}$ & $\mathrm{n}$ & $\mathrm{n}$ & $\mathrm{s}$ & $\mathrm{s}$ & $\mathrm{s}$ & $\mathrm{n}$ & $\mathrm{n}$ & $\mathrm{s}$ & $\mathrm{n}$ & $\mathrm{n}$ & $\mathrm{n}$ & 9 \\
\hline $\begin{array}{l}\text { Ausência de focos de violência e intimidação de } \\
\text { eleitores }\end{array}$ & $\mathrm{s}$ & $\mathrm{s}$ & $\mathrm{n}$ & $\mathrm{n}$ & $\mathrm{s}$ & $\mathrm{n}$ & $\mathrm{n}$ & $\mathrm{s}$ & $\mathrm{n}$ & $\mathrm{n}$ & $\mathrm{s}$ & $\mathrm{s}$ & $\mathrm{s}$ & $\mathrm{n}$ & $\mathrm{n}$ & $\mathrm{n}$ & $\mathrm{n}$ & $\mathrm{n}$ & $\mathrm{n}$ & 7 \\
\hline Garantia do segredo de voto nas cabines & $\mathrm{n}$ & $\mathrm{n}$ & $\mathrm{n}$ & $\mathrm{n}$ & $\mathrm{n}$ & $\mathrm{n}$ & $\mathrm{n}$ & $\mathrm{n}$ & $\mathrm{n}$ & $\mathrm{n}$ & $\mathrm{n}$ & $\mathrm{n}$ & $\mathrm{n}$ & $\mathrm{n}$ & $\mathrm{n}$ & $\mathrm{n}$ & $\mathrm{n}$ & $\mathrm{n}$ & $\mathrm{n}$ & 0 \\
\hline $\begin{array}{l}\text { Fácil identificação dos centros de votação pelos } \\
\text { eleitores }\end{array}$ & $\mathrm{s}$ & s & $\mathrm{n}$ & $\mathrm{s}$ & $\mathrm{s}$ & s & $\mathrm{s}$ & $\mathrm{s}$ & s & s & $\mathrm{n}$ & $\mathrm{n}$ & $\mathrm{n}$ & $\mathrm{n}$ & $\mathrm{n}$ & $\mathrm{s}$ & $\mathrm{n}$ & $\mathrm{n}$ & $\mathrm{n}$ & 10 \\
\hline $\begin{array}{l}\text { Ausência de práticas ilegais de voto como compra e } \\
\text { coerção }\end{array}$ & $\mathrm{s}$ & $\mathrm{s}$ & s & $\mathrm{n}$ & $\mathrm{n}$ & $\mathrm{n}$ & $\mathrm{n}$ & $\mathrm{n}$ & $\mathrm{n}$ & $\mathrm{n}$ & $\mathrm{n}$ & $\mathrm{n}$ & $\mathrm{n}$ & $\mathrm{n}$ & $\mathrm{n}$ & $\mathrm{n}$ & $\mathrm{n}$ & $\mathrm{n}$ & $\mathrm{n}$ & 3 \\
\hline$N^{\circ} \operatorname{sim}$ & 6 & 7 & 2 & 4 & 6 & 5 & 4 & 5 & 6 & 3 & 4 & 6 & 6 & 3 & 3 & 8 & 1 & 6 & 6 & Total $=91$ \\
\hline
\end{tabular}

Fonte: Relatórios das missões de observação eleitoral internacionais. Elaboração própria.

Índice de governança eleitoral no dia da eleição $=0.39$ 
Tabela 9 - Matriz de observação pós-eleitorais, Haiti, 1990-2015

\begin{tabular}{|c|c|c|c|c|c|c|c|c|c|c|c|c|c|c|c|c|c|c|c|c|}
\hline Indicadores/Anos & $\frac{8}{\frac{8}{\sigma}}$ & $\frac{\text { 욤 }}{\text { Фூ }}$ & $\frac{\sqrt{g}}{\frac{\sigma}{2}}$ & 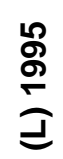 & 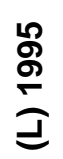 & $\begin{array}{l}\text { o̊ } \\
\stackrel{\sigma}{\sigma} \\
\text { யூ }\end{array}$ & 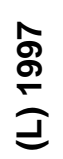 & $\begin{array}{l}\text { ㅇ } \\
\text { ㅇ } \\
\text { 己 }\end{array}$ & $\begin{array}{l}\text { ㅇ } \\
\text { ㅇ } \\
\text { 己 }\end{array}$ & $\begin{array}{l}\stackrel{8}{\circ} \\
\text { N } \\
\text { யூ }\end{array}$ & 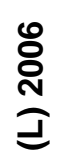 & $\begin{array}{l}\text { ㅇ } \\
\stackrel{N}{ } \\
\text { ב }\end{array}$ & $\begin{array}{l}\text { O̊ } \\
\text { ํ } \\
\text { யூ }\end{array}$ & $\begin{array}{l}0 \\
\frac{\mathfrak{N}}{2} \\
\text { J }\end{array}$ & $\begin{array}{l}\stackrel{0}{\delta} \\
\text { ㅇ } \\
\text { யூ }\end{array}$ & 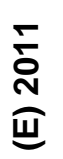 & $\begin{array}{l}\frac{n}{0} \\
\stackrel{N}{J} \\
\beth\end{array}$ & 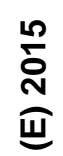 & $\begin{array}{l}\frac{1}{\delta} \\
\stackrel{N}{J}\end{array}$ & Número de sim \\
\hline $\begin{array}{l}\text { Transporte adequado de material sensível para } \\
\text { contagem }\end{array}$ & $\mathrm{n}$ & $\mathrm{n}$ & $\mathrm{n}$ & $\mathrm{n}$ & $\mathrm{n}$ & $\mathrm{n}$ & $\mathrm{n}$ & $\mathrm{n}$ & $\mathrm{n}$ & $\mathrm{n}$ & $\mathrm{n}$ & s & s & $s$ & s & s & $\mathrm{n}$ & $\mathrm{n}$ & $\mathrm{n}$ & 5 \\
\hline $\begin{array}{l}\text { Fechamento do centro no horário estipulado pela } \\
\text { lei }\end{array}$ & $\mathrm{n}$ & $\mathrm{n}$ & $\mathrm{n}$ & $\mathrm{n}$ & $\mathrm{n}$ & $\mathrm{n}$ & $\mathrm{n}$ & s & $\mathrm{n}$ & $\mathrm{n}$ & $\mathrm{n}$ & $\mathrm{n}$ & $\mathrm{n}$ & $\mathrm{n}$ & $\mathrm{n}$ & $\mathrm{n}$ & $\mathrm{n}$ & $s$ & s & 3 \\
\hline Contagem adequada preliminar e final dos votos & $\mathrm{s}$ & $\mathrm{s}$ & $\mathrm{s}$ & $\mathrm{n}$ & $\mathrm{n}$ & $\mathrm{n}$ & $\mathrm{n}$ & $\mathrm{n}$ & $\mathrm{n}$ & $\mathrm{n}$ & $\mathrm{n}$ & $\mathrm{s}$ & s & $\mathrm{n}$ & $\mathrm{n}$ & s & $\mathrm{n}$ & $\mathrm{n}$ & $\mathrm{n}$ & 6 \\
\hline Rápida divulgação de resultados & $\mathrm{n}$ & $\mathrm{n}$ & $\mathrm{n}$ & $\mathrm{n}$ & $\mathrm{n}$ & $\mathrm{n}$ & $\mathrm{n}$ & $\mathrm{n}$ & $\mathrm{n}$ & $\mathrm{n}$ & $\mathrm{n}$ & $\mathrm{s}$ & s & $\mathrm{n}$ & $\mathrm{n}$ & $\mathrm{s}$ & $\mathrm{n}$ & $\mathrm{n}$ & $\mathrm{n}$ & 3 \\
\hline $\begin{array}{l}\text { Pouca divergência entre resultados preliminar e } \\
\text { final }\end{array}$ & $\mathrm{s}$ & s & s & $\mathrm{n}$ & $\mathrm{n}$ & $\mathrm{n}$ & $\mathrm{n}$ & $\mathrm{n}$ & $\mathrm{n}$ & s & $\mathrm{n}$ & S & s & s & s & S & $\mathrm{n}$ & $\mathrm{n}$ & $\mathrm{n}$ & 9 \\
\hline Existência de instância para análise de denúncias & $\mathrm{n}$ & $\mathrm{n}$ & $\mathrm{n}$ & $\mathrm{n}$ & $\mathrm{n}$ & $\mathrm{n}$ & $\mathrm{n}$ & S & s & S & S & S & S & $S$ & S & S & S & $S$ & $\mathrm{~s}$ & 12 \\
\hline $\begin{array}{l}\text { Padronização de procedimentos entre centro de } \\
\text { votação }\end{array}$ & $\mathrm{n}$ & $\mathrm{n}$ & $\mathrm{n}$ & $\mathrm{n}$ & $n$ & $\mathrm{n}$ & $\mathrm{n}$ & $\mathrm{n}$ & $\mathrm{n}$ & $n$ & $\mathrm{n}$ & $\mathrm{s}$ & $\mathrm{n}$ & $S$ & S & $\mathrm{s}$ & $S$ & $S$ & S & 7 \\
\hline $\begin{array}{l}\text { Aceitação dos resultados finais por candidatos e } \\
\text { oposição }\end{array}$ & $\mathrm{S}$ & $\mathrm{s}$ & $\mathrm{n}$ & $S$ & $n$ & $\mathrm{n}$ & $\mathrm{n}$ & $\mathrm{n}$ & s & $n$ & $\mathrm{n}$ & $n$ & $\mathrm{n}$ & $S$ & S & $n$ & $n$ & $S$ & s & 8 \\
\hline Instrumentos confiáveis de contagem e tabulação & $\mathrm{n}$ & $\mathrm{n}$ & $\mathrm{n}$ & $\mathrm{n}$ & $\mathrm{n}$ & $\mathrm{n}$ & $\mathrm{n}$ & $\mathrm{n}$ & $\mathrm{n}$ & $\mathrm{n}$ & $\mathrm{n}$ & $\mathrm{n}$ & $\mathrm{n}$ & $\mathrm{n}$ & $\mathrm{n}$ & s & $\mathrm{n}$ & $\mathrm{n}$ & $\mathrm{n}$ & 1 \\
\hline Ausência de muitos votos em um candidato apenas & $\mathrm{n}$ & $\mathrm{n}$ & $\mathrm{s}$ & $\mathrm{n}$ & $\mathrm{n}$ & $\mathrm{n}$ & $\mathrm{s}$ & $\mathrm{s}$ & $\mathrm{s}$ & $\mathrm{n}$ & $\mathrm{s}$ & $\mathrm{s}$ & $\mathrm{s}$ & $\mathrm{n}$ & $\mathrm{n}$ & $\mathrm{s}$ & $\mathrm{s}$ & $\mathrm{s}$ & $\mathrm{s}$ & 11 \\
\hline Ausência de violência pós-eleitoral & $\mathrm{s}$ & $\mathrm{s}$ & $\mathrm{n}$ & $\mathrm{s}$ & s & $\mathrm{s}$ & $\mathrm{n}$ & $\mathrm{n}$ & $\mathrm{n}$ & $\mathrm{n}$ & $\mathrm{n}$ & $\mathrm{n}$ & $\mathrm{n}$ & $\mathrm{n}$ & $\mathrm{n}$ & $\mathrm{n}$ & $\mathrm{n}$ & $\mathrm{n}$ & $\mathrm{n}$ & 5 \\
\hline Baixo índice de abstenções (presença e voto) & $\mathrm{n}$ & $\mathrm{n}$ & $\mathrm{n}$ & $\mathrm{n}$ & $\mathrm{n}$ & $\mathrm{n}$ & $\mathrm{n}$ & $\mathrm{s}$ & $\mathrm{s}$ & $\mathrm{n}$ & $\mathrm{s}$ & $\mathrm{n}$ & $\mathrm{s}$ & $\mathrm{n}$ & $\mathrm{n}$ & $\mathrm{n}$ & $\mathrm{n}$ & $\mathrm{n}$ & $\mathrm{n}$ & 4 \\
\hline $\mathbf{N}^{\circ} \operatorname{sim}$ & 4 & 4 & 3 & 2 & 1 & 1 & 1 & 4 & 4 & 2 & 3 & 7 & 7 & 5 & 5 & 8 & 3 & 5 & 5 & Total $=74$ \\
\hline & & & & & & & & & & & & & & & & & & & & Na máximo de sim $=228$ \\
\hline
\end{tabular}

Índice de governança eleitoral no dia da eleição $=0.3$ 
O índice de governança eleitoral é um pouco melhor para o dia da votação. Esse resultado é compatível com os estudos de Hyde (2007), Ichino e Schundeln (2012) e Donno (2010). Estes pesquisadores indicam a menor possibilidade de ocorrência de manipulações no processo eleitoral, dado a presença dos observadores torna mais difícil a fraude no dia da eleição. Para os autores, muitos políticos acabam por tentar fraudar o processo em seus estágios iniciais, por acreditar que correm menor risco de serem descobertos. Mesmo assim, é grande a possibilidade de que fraudes sejam encontradas, sobretudo porque os observadores têm permanecido por um período cada vez mais longo, nos países onde fazem observação.

Os índices mais baixos para os períodos pré e pós-eleitoral estão de acordo com a literatura proposta por Bjornlund (2004); Carothers (1997) e Hyde e O'Mahoney (2010). Para os autores as más práticas deixaram de estar concentradas no dia da eleição, para se concentrarem em outras etapas do período eleitoral.

No período pré-eleitoral, os observadores apontaram a pouca fiscalização dos financiamentos de campanha que, muitas vezes, beneficiam o partido incumbente. Muitos dos principais partidos políticos do país são ligados a grupos paramilitares e gangues, de onde provém parte substancial de seus recursos de campanha, algo que foi apontado pela OIF, nas eleições de 2006 (OIF, 2006). Tais grupos "são leais a determinados partidos e, muitas vezes, são enviados a comícios e reuniões políticas para causar algum tipo de violência" (Waleck et al, 2006). Ou seja, ao mesmo tempo em que as gangues podem financiar partidos, os partidos políticos também contratam membros de grupos armados e gangues para Ihes auxiliar nas campanhas contrárias aos demais candidatos, criando tumultos em seus comícios. A maior fonte de recursos dessas gangues e grupos armados são sequestros, tráfico de drogas e extorsão (idem).

Também tem destaque no período pré-eleitoral a inexistência de um organismo eleitoral independente, frequentemente apontado pelos observadores como uma falha que diminui a pontuação no índice de boa governança para essa fase. Segundo McCoy, Hartlyn e Mustillo (2008), a tendência mais generalizada no mundo hoje, sobretudo nas novas democracias, é a do estabelecimento de organismos eleitorais independentes, permanentes e multipartidárias, fato que não se observa no Haiti. 
Hoyos e Loza (2014) argumentam que os processos de transformação democrática recentes na América Latina, foram acompanhados do estabelecimento de órgãos eleitorais, cujo papel é fundamental para a estabilidade política e, consequentemente, para sua consolidação democrática. Tais órgãos são as instituições encarregadas diretamente da organização das eleições e contribuem de forma direta para aplicação das leis eleitorais (idem). No Haiti, houve várias tentativas de se criar um organismo eleitoral dentro desse modelo comentado pelos autores, no entanto, a cada eleição, novas comissões eleitorais são formadas, gerando muitos conflitos internos entre cada um dos representantes dos grupos sociais, envolvidos na organização e condução do processo eleitoral.

A fase pré-eleitoral - de competição - apresenta um componente importante do processo eleitoral haitiano. A intensificação dos protestos populares em 1986, que apoiavam, entre outras questões, a realização de eleições livres, seguiu-se a assinatura de uma nova constituição que retirava uma série de impedimentos à livre expressão, características da ditadura de Duvalier. "Mais de sessenta partidos políticos foram formados e vários grupos de pressão, organizações religiosas e de trabalho, foram criadas" (Kessing's, 12/12/1986). Assim, as eleições no país, passaram a ser mais que concorridas, havendo profusão de partidos políticos e candidatos em disputa. Embora existam restrições que diminuem a real competição política, envolvendo irregularidades como as diferenças quanto ao financiamento de campanhas e as desigualdades no tempo de exposição da mídia dos candidatos, esse é um quesito que aparece como minimamente estabelecido, no caso haitiano.

Para Nohlen (1994), para que as eleições cumpram com seu caráter democrático, ou seja, para que elas sejam competitivas, é necessário que preencham certos requisitos principais, entre os quais podem ser destacados: (1) igualdade de oportunidades quanto à postulação de partidos e candidatos; (2) liberdade de eleição, assegurada pela emissão secreta do voto; (3) um sistema eleitoral com regras bem definidas; (4) disputa livre e competitiva, entre outros.

Sendo o Haiti uma democracia eleitoral (Freedom House, 2016), há que se mencionar falhas no que tange a competição política existente no país, mais especificamente, centrada nos dois primeiros pontos citados por Nohlen (1994). 
No entanto, para os observadores, ainda que eles vejam entraves à participação política de determinadas agremiações políticas, de um modo geral, isso não inviabiliza o processo eleitoral como um todo, uma vez que dentro do universo de partidos e candidatos, ainda há competição política.

Em 2015, o CEP confirmou a candidatura de vinte e sete concorrentes para as eleições presidenciais, além de setenta partidos políticos, agremiações e agrupamentos políticos habilitados a indicar candidatos (CEP, 2015a; 2015b).

Outra situação muito apontada pelos observadores foi a dificuldade de coordenação entre os diferentes organismos eleitorais, a exemplo do Escritório Departamental de Eleições (BED), Escritório Comunal Eleitoral (BEC) e o próprio CEP ${ }^{71}$. Os observadores apontaram muitas diferenças na forma como cada um dos organismos realizava seu trabalho, dificultando a coordenação entre eles. Como consequência, eles apontaram que a coordenação dos processos eleitorais fica prejudicava por essa situação em quase todos os anos analisados. Nelson (1998) cita o caso, por exemplo, das eleições de 1995 em que a desorganização do CEP se tornou evidente quando

“... ao invés de fazer a contagem nos centros de votação, oficiais eleitorais carregaram urnas fechadas aos BECs locais, que tinham segurança visível (Minustah) e lâmpadas funcionando. Nenhum dos BECs estava preparado para essa contingência. No BEC de Porto Príncipe, por exemplo, milhares de oficiais eleitorais jogaram suas urnas no lixo; outros as esvaziaram na calçada e iniciaram a contagem " (р. 77).

O presidente Aristide (1991-1991) interveio após reclamações de candidatos dos maiores partidos políticos e substituiu alguns membros do CEP, inclusive seu presidente. Como resposta às frequentes reclamações de partidos políticos e candidatos, o CEP se converteu, nos últimos anos, em uma instância mais técnica, capaz de responder às críticas. Assim, o autor cita o

“... novo profissionalismo traduzido em melhor administração e organização de cima para baixo, ao longo de toda a administração eleitoral. O planejamento melhorou, centros de votação foram reorganizados, aumentou o número de treinamentos voltados aos oficiais eleitorais, e atrasos foram minimizados" (idem, p. 78).

Porém, a politização do organismo eleitoral continua um problema para a boa governança eleitoral. Em 2009, aumentaram as percepções negativas sobre

${ }^{71}$ Além desses, fazem parte da estrutura funcional das eleições: partidos políticos e candidatos; oficiais de governos regionais e locais; Missão Civil Internacional no Haiti (MICIVIH), Minustah, Polícia Civil (CIVPOL); Força Interina de Segurança Pública (IPSF), Polícia Nacional Haitiana (HNP) e a população haitiana. 
os critérios utilizados pelo CEP para o período do registro de partidos de oposição, quando, "o conselho eleitoral desqualificou sem explicação cerca de 15 grupos políticos rivais" (Taft-Morales, 2011, p. 16). Entre os grupos políticos rivais que não tiveram seu registro validado estava o Fwon Lespwa (Fronte da Esperança, em créole), mesmo partido que ajudou na eleição de René Préval (2006 -2011), mas que não aceitou fazer parte de sua nova agremiação política, a União (Inite, em créole). Assim, para os observadores internacionais a falta de credibilidade do CEP é apontada como um dos maiores obstáculos à legitimidade das eleições haitianas.

Na etapa pré-eleitoral é notória também a presença de grupos armados que tendem a agir com maior ou menor inserção através das eleições. Em 2006, a escalada de violência ocasionada pela ação de gangues em muitas partes do país, culminou com a morte de dois peacekeepers em uma emboscada na Cité Soleil, em Porto Príncipe (BBC, 11/11/2006). A partir daí o governo haitiano e a Minustah passaram a colaborar ativamente na promoção da segurança, em virtude da proximidade do dia da votação para escolha de um novo presidente. No entanto, apesar do reforço na segurança, os observadores relataram o aumento de raptos e emboscadas, além de outros tipos de delitos, quando a maioria dos eleitores saiu de suas casas para votar.

Em 2015, a violência se deu por meio de protestos que se estenderam ao longo de toda a jornada eleitoral, além da tentativa de grupos armados de retirar urnas e cédulas de votação, em centros eleitorais, sendo que para isso ameaçavam os chefes de mesa (OEA, 2015). Na primeira volta das eleições parlamentares, especificamente, foram registrados vários casos de tentativa de intimidação e violência contra eleitores (idem).

Uma das formas de se combater as manipulações é através do grau de esclarecimento dos eleitores sobre como e porque se vota. Contudo, o dia da votação nas eleições haitianas da Terceira Onda de democratização foram marcadas por pouco conhecimento do eleitor sobre o conteúdo das eleições ou sobre como ele deveria preencher seu voto.

Além disso, no dia da eleição as manipulações estão ligadas a tentativas de intimidação de eleitores e focos de violência eleitoral. No Haiti, os observadores relataram a manifesta presença de representantes de partidos políticos (mandataires) exercendo algum tipo de pressão para que os eleitores 
votassem em candidatos de seus partidos, em muitas das eleições em que estiveram presentes (IRI, 1990; 1995; OEA, 2015). A violência eleitoral foi registrada pelos estrangeiros em centros de votação, nos quais, por exemplo, urnas e outros materiais foram queimados nas ruas, por manifestantes contrários às eleições, sobretudo nas campanhas que faziam parte de alguma tentativa de desmobilização da população ou contrária ao governo (IRI, 1995; 1997).

A primeira volta das eleições parlamentares de 2015 foram marcadas, segundo os observadores, pelo ataque a centros de votação por parte de gangues que entraram nos centros eleitorais munidas de pedras e garrafas, forçando o fechamento destes (EU, 2015).

Além disso, o atraso na abertura dos centros de votação também foi apontado como um aspecto a ser melhorado desde as eleições fundacionais, mas que, mesmo assim, permaneceu como um problema até a última eleição realizada, com algumas poucas exceções (OEA, 2000, 2006, 2015; OEA/Caricom, 2010).

Além do atraso na abertura, o fechamento tardio de centros de votação também apareceu como uma recomendação ao governo haitiano em cada uma de suas eleições, mas que não melhorou ao longo dos anos, com exceção das últimas votações gerais realizadas em 2015 (OEA, 2000, 2015; OIF, 2006; OEA/Caricom, 2010).

As divergências nas contagens dos votos também apareceram como aspectos recorrentes nas eleições haitianas. Em 2006, essas divergências levaram ao incremento de episódios de violência pós-eleitoral através de uma série de massivos e, por vezes, violentos protestos nas ruas (Dupuy, 2006; OIF, 2006; OEA, 2006). Após seu adiamento por quatro vezes, as eleições foram realizadas e novamente René Préval, da coalizão Fwon Lespwa, foi eleito. Sua vitória foi cercada de controvérsia. Embora projeções iniciais de organizações internacionais, a exemplo da OEA e NDI, apontassem para a vitória de Préval no primeiro turno, com mais de $50 \%$ dos votos, no dia da eleição, sua porcentagem caiu para $49 \%$. Como resultado, "acreditando que aqueles que queriam impedilo de vencer no primeiro turno estavam manipulando a contagem de votos e promovendo fraudes, partidários tomaram as ruas em protestos que paralisaram Porto Príncipe e outras cidades em todo o Haiti" (idem, p. 133). 
$\mathrm{Na}$ mesma eleição, denúncias de fraude aumentavam, e o governo haitiano juntamente com as Nações Unidas e a OEA, foram deixando de negar erros ou falhas, mudando de atitude. Entre as falhas estavam a descoberta de vários votos em branco em distritos menos monitorados e a contestação de um número de votos era inferior ao número de cidadãos que haviam votado em alguns centros eleitorais. Além disso, aproximadamente $4 \%$ dos votos gerais não foram encontrados e, portanto, não estavam contabilizados nos resultados divulgados (ibidem).

Tais acontecimentos poderiam ser evitados caso houvesse rápida divulgação de resultados preliminares e finais. No entanto, a falta de padronização dos procedimentos em cada centro de votação faz com que essa situação se prolongue ao longo dos anos. Somado a isso, há o fato de que em muitos centros eleitorais os recursos são escassos, a exemplo da energia, que não é fornecida para a maioria dos locais de votação, como descrito em vários dos relatórios das missões (IRI, 1997; OEA, 2000; 2015; OEA/Caricom, 2010).

Em função de situações como intimidação, falta de segurança e pouca credibilidade do processo eleitoral, muitos haitianos deixam de comparecer às urnas no dia da votação, gerando um índice muito alto de abstenções. Desde as eleições fundacionais, as missões indicam baixas porcentagens de presença de eleitores nos centros, com o comparecimento de eleitores girando em torno de $20 \%$ a 30\% em cada eleição. Apesar das recomendações das missões de que o governo invista mais em campanhas de conscientização, são as campanhas de desmobilização que parecem mobilizar mais os cidadãos.

No primeiro turno das eleições de 2000 , contudo, aproximadamente $60 \%$ dos votantes compareceram. Contudo, o segundo turno foi marcado pela fraca participação popular, devido, sobretudo, à enorme proporção de votos $(90 \%)$ obtidos pelo partido do presidente Aristide, na primeira rodada.

Em 2010, onze meses depois do terremoto que deixou uma série de deslocados internos e provocou uma epidemia de cólera, o CEP organizou uma eleição, considerada "fundamentalmente sólida", pelos observadores da OEA/Caricom, porém, com pouca participação (OEA/Caricom, 2010). Isso ocorreu em função da dificuldade das pessoas de chegarem até os centros eleitorais. 
O desrespeito ao calendário eleitoral é algo evidenciado pela observação internacional, sobretudo porque muitas das datas pré-estabelecidas são modificadas a poucos dias antes das eleições. Em 2015, o processo eleitoral foi adiado ao ponto que um governo interino teve que assumir a condução do país que já estava há meses sem presidente. As organizações internacionais de observação, desempenharam um papel mais especializado nesse período, apoiando as negociações para o estabelecimento de novas datas para as eleições. Como McCoy et al (1991) e Pastor (1998) apontaram que os observadores assumiram um papel de mediadores, uma vez que a principal preocupação era garantir a manutenção da democracia através de eleições. A observação internacional nesses casos é mais uma técnica de resolução de conflitos domésticos, e não um instrumento para resolver conflitos internacionais.

Quanto às campanhas eleitorais, a preocupação do CEP estava inicialmente em controlar o que era divulgado pelos partidos políticos. Figuras políticas públicas ficavam assim proibidas de manifestar seu apoio a qualquer um dos candidatos em disputa e todos os materiais divulgados deveriam ser antes submetidos aos BECs (IRI, 1990). No entanto, nos anos que se seguiram o foco muda, uma vez que a violência pré-eleitoral crescera em demasia.

$O$ atraso na entrega de material sensível para os centros eleitorais, também é uma falha recorrente do CEP, que, nos últimos anos, deixou de aparecer com tanta frequência devido ao fato de que a Minustah, além de promover a segurança dos eleitores, também passou a auxiliar o Conselho no fornecimento e armazenamento de urnas, cédulas, listas de votantes e outros materiais essenciais ao processo (OEA, 2000; 2015; OEA/Caricom, 2010).

No que tange a organização do processo eleitoral no dia da eleição, destarte a melhoria nesse quesito, a abertura dos centros de votação continua ocorrendo com falta de membros das mesas e de material sensível; Além da dificuldade em chegar até os centros, muitos deles não possuem identificação fácil. Grande parte dos centros eleitorais que constam na lista divulgada pelo CEP costumam estar fechados, tendo como consequência, a realocação de eleitores em outros colégios eleitorais. Esse problema foi apontado pelos observadores do IRI, no processo eleitoral de 1995, quando muitos dos eleitores se viram surpresos ao chegar nos locais onde haviam se registrado, e descobriram que seus locais de votação tinham sido alterados (IRI, 1995). 
Seguindo o fim do dia de votação tem início a contagem dos votos, as quais são acompanhadas de perto pelos representantes dos partidos políticos. Há, no entanto, muitas reclamações sobre a conduta e forma de contagem dos membros da mesa, que, por vezes, são verídicas, porém, na maioria das vezes, são estratégias utilizadas como forma de criar algum tipo de divergência que beneficie um candidato em desvantagem. Assim, que é finalizada a tabulação de voto paralela (PVT), os resultados são enviados aos BECs para nova recontagem no dia seguinte, e assim por diante, até chegar ao CEP, para que os resultados finais sejam divulgados. A divergência entre uma e outra contagem, no entanto, tem causado atritos entre os diferentes partidos em disputa. Em 1995, a contagem final realizada pelo CEP foi apontada pelos observadores como destoante da contagem que havia sido realizada nos BEDs. Para eles, essa situação pode ter sido causada pelo fato de que o preenchimento manual de todas as atas finais pode ter implicado em erros, em especial, pelo fato de que eram escritas várias cópias para cada uma das atas (IRI, 1995).

Da mesma forma, a concentração de muitos votos em um candidato em eleições consecutivas, apesar da existência de um grande número de candidatos é apontado como um ponto frágil da competição eleitoral. Beaulieu e Hyde (2009), mostram que esse foi o caso, por exemplo, das eleições de 2000, quando Jean Bertrand-Aristide foi eleito com uma ampla vantagem sobre o grande número de candidatos, apesar dessa concentração de votos, a eleições no país sempre contaram com bom grau de competição política.

Em 1995, contudo, os observadores alertaram para o segundo turno das eleições legislativas, que contou com "relativa segurança, participação limitada e competição mínima" (IRI, 1995, s. p.). Em suas conclusões, eles argumentam que após as eleições presidenciais, no mesmo ano, as eleições legislativas estavam dominadas por um único partido, argumentando que "a situação atual não pode ser assumida como sendo reflexo da 'vontade do povo', pelo menos a este respeito" (idem). Da mesma forma, o grupo indicou que o ambiente de competição não tinha melhorado para as eleições seguintes, em 1997, com a coalisão Lavalas dominando o cenário político (IRI, 1997).

Por fim, as denúncias de fraudes, irregularidades, intimidação, coação ou qualquer outro tipo de assunto relacionado às eleições, é recebido de forma direta pelo CEP ou através das missões. É mais comum que as denúncias sejam 
realizadas no dia da votação e recebidas pelos observadores, que, depois, relatam a situação observadas aos coordenadores, os quais irão, por sua vez, agregá-las ao relatório final e que será divulgado posteriormente.

A presença de mandataires foi uma queixa constante no processo eleitoral de 2010. Apesar da determinação do CEP de que não mais que cinco representantes de partido pudessem estar presentes em um centro eleitoral, embora todos pudessem estar presentes no momento da contagem verbal, gerou problemas ao final do processo. "Muitos representantes de partido reivindicaram que sua presença havia sido barrada em vários locais de votação" (OEA/Caricom, 2010, p. 138). Porém, segundo os observadores, a reclamação não era verídica, mas antes, uma tentativa de impedir a correta execução do processo, tornando-o fraudulento.

\subsection{Impacto das missões de observação: implementação das recomendações}

Ao considerarmos que as missões de monitoramento internacional visam não somente diminuir ou desestimular a fraude no dia da votação, temos as recomendações, que são iniciativas criadas com o intuito de contribuir para melhorias na governança eleitoral no longo prazo. Essa é uma das razões, por exemplo, para que existam grandes investimentos por parte das organizações internacionais em enviar observadores meses antes do dia da votação, mantendo-os por determinado tempo em campo.

Mais especificamente, com relação às recomendações, podemos dizer que elas chamam atenção para problemas recorrentes nos países que realizarão eleições. Os observadores podem fazer recomendações sobre aspectos legais, processuais, organizacionais etc.

De uma forma geral, as recomendações das missões tiveram impacto baixo nas eleições haitianas, conforme quadro e tabelas que são apresentados abaixo.

Quadro 6 - Índice de Implementação das recomendações das MOEIs, Haiti

\begin{tabular}{ccc}
\hline País & Fase & Índice \\
\hline Haiti & Pré-eleitoral & $0.39 \rightarrow$ Baixo
\end{tabular}


Tabela 9 - Matriz de recomendações para o período pré-eleitoral, Haiti, 1990-2015

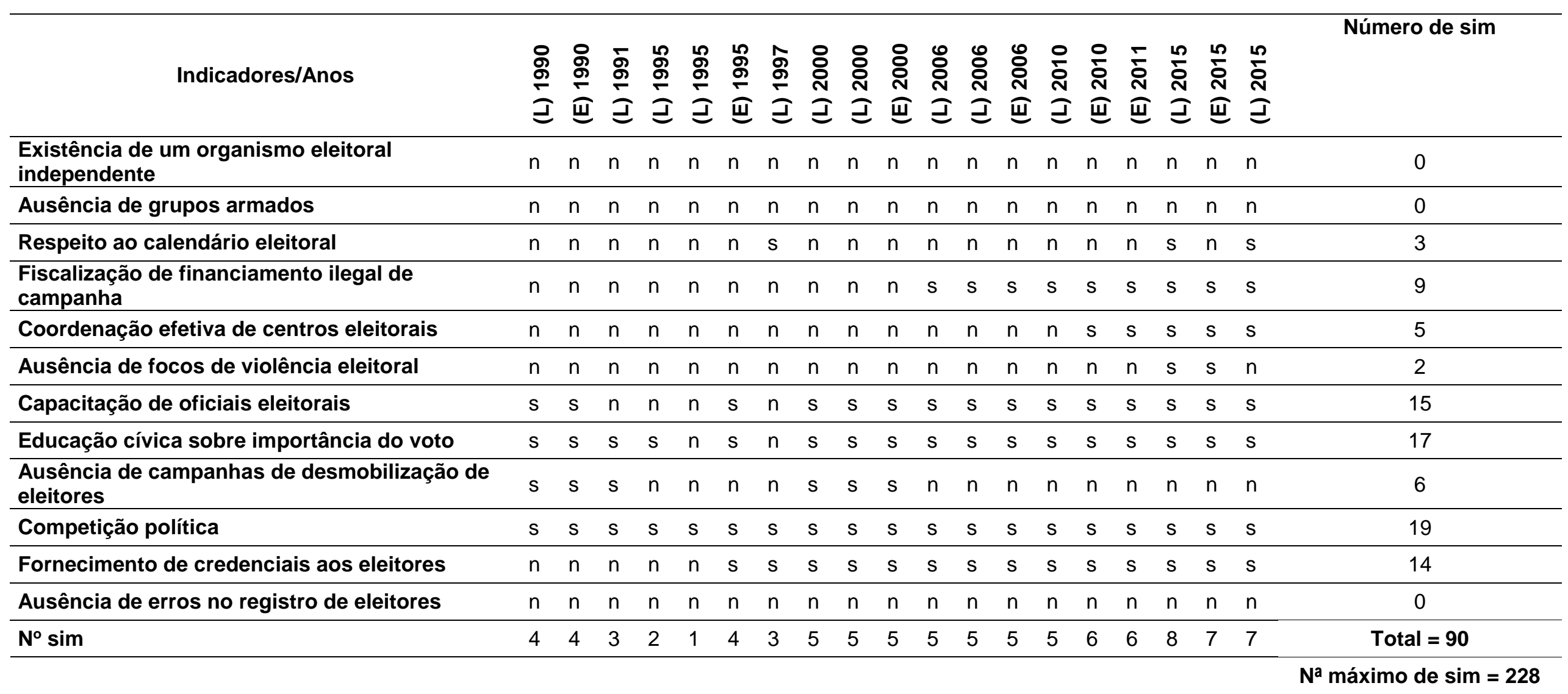

Fonte: Relatórios das missões de observação eleitoral internacionais. Elaboração própria.

Índice de implementação das recomendações $=0.39$ 
Tabela 10 - Matriz de recomendações para o dia da eleição, Haiti, 1990-2015

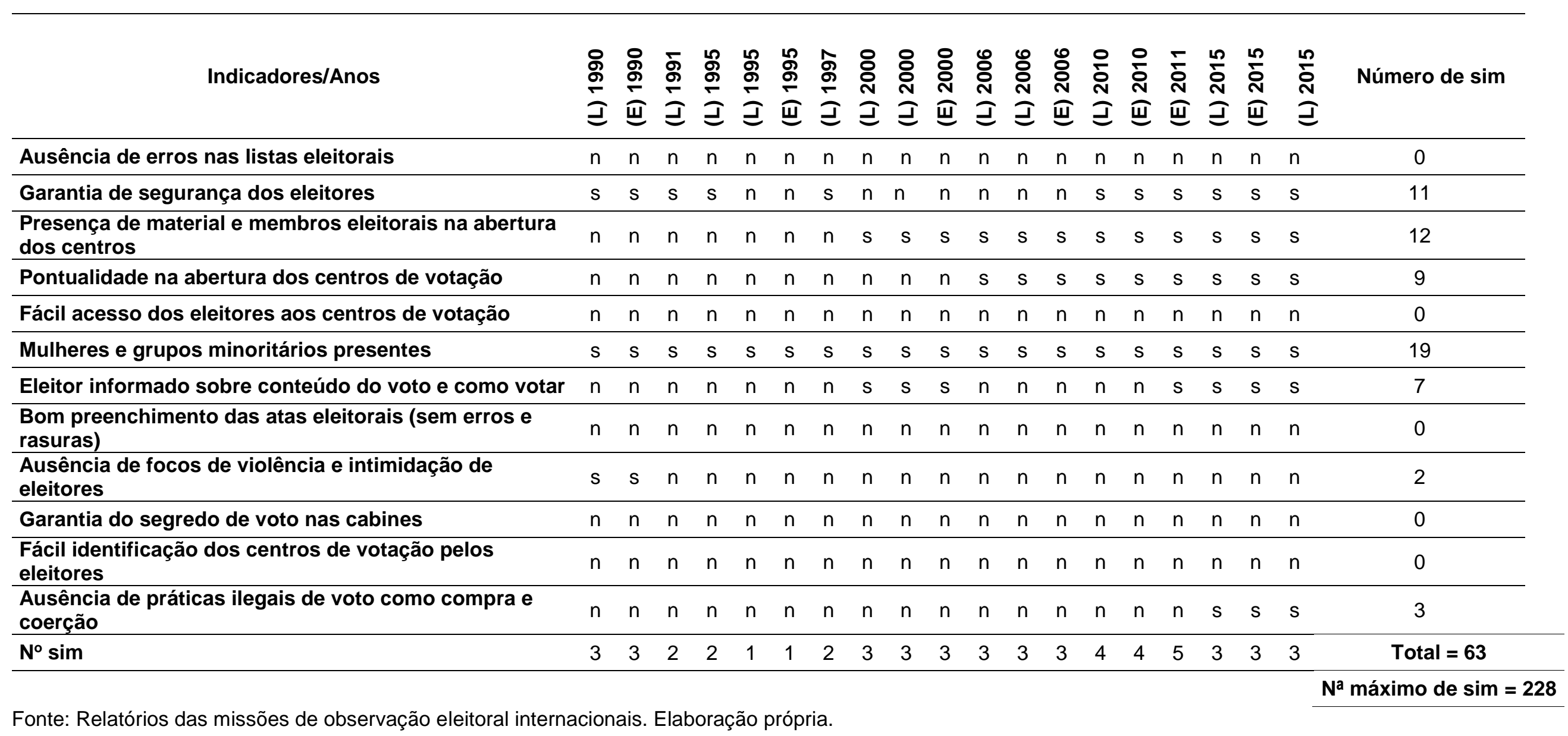

Índice de implementação das recomendações $=0.27$ 
Tabela 11 - Matriz de recomendações pós-eleitorais, Haiti, 1990-2015

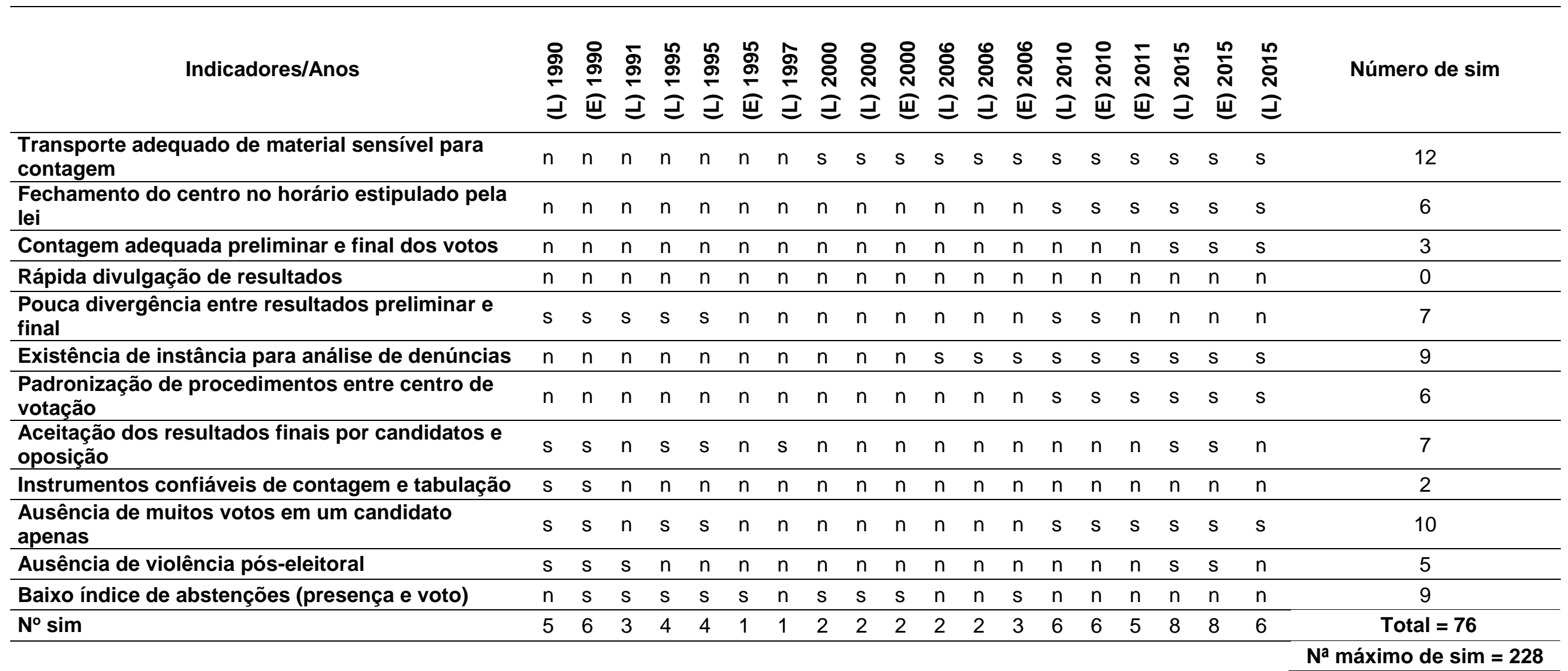

Fonte: Relatórios das missões de observação eleitoral internacionais. Elaboração própria.

Índice de implementação das recomendações $=0.33$ 
Ao contrário do observado para o índice de boa governança eleitoral, suas recomendações tiveram menor impacto, no dia da votação. Isso poderia ser explicado pelo fato da presença dos observadores ser uma condição importante, enquanto a implementação das recomendações depende de mudanças introduzidas pelo organismo eleitoral, o que, no caso haitiano, só ocorre uma vez por ano.

A interpretação dos dados nos levou a identificar três tendências principais, quanto ao acatamento das recomendações das missões que estiveram mais presentes nas eleições realizadas, mais ou menos presentes e menos presentes: (1) recomendações do processo eleitoral que nunca são acatadas; (2) recomendações que são implementadas em determinadas eleições e em outras não e (3) recomendações que mudam a partir de determinada eleição. Conforme quadro a seguir:

\section{Quadro 7 - Implementação das recomendações das MOEls, Haiti}

\begin{tabular}{|c|c|c|c|}
\hline Período & & Observações & 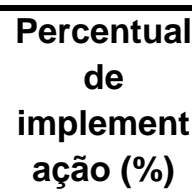 \\
\hline \multirow{12}{*}{$\begin{array}{l}\text { Pré- } \\
\text { eleitoral }\end{array}$} & \multirow{7}{*}{$\begin{array}{c}\text { Não } \\
\text { implementada } \\
\mathrm{s}[1]\end{array}$} & Existência de um organismo eleitoral independente & $0 \%$ \\
\hline & & Ausência de grupos armados & $0 \%$ \\
\hline & & Ausência de erros no registro de eleitores & $0 \%$ \\
\hline & & Ausência de focos de violência eleitoral & $10 \%$ \\
\hline & & Respeito ao calendário eleitoral & $15 \%$ \\
\hline & & Coordenação efetiva de centros eleitorais & $26 \%$ \\
\hline & & Ausência de campanhas de desmobilização de eleitores & $31 \%$ \\
\hline & \multirow{3}{*}{$\begin{array}{c}\text { Parcialmente } \\
\text { implementada } \\
\text { s [2] }\end{array}$} & Fiscalização de financiamento ilegal de campanha & $47 \%$ \\
\hline & & Fornecimento de credenciais aos eleitores & $73 \%$ \\
\hline & & Capacitação de oficiais eleitorais & $78 \%$ \\
\hline & \multirow{2}{*}{$\begin{array}{l}\text { Implementada } \\
\text { s [3] }\end{array}$} & Educação cívica sobre importância do voto & $89 \%$ \\
\hline & & Competição política & $100 \%$ \\
\hline \multirow{13}{*}{$\begin{array}{l}\text { Dia da } \\
\text { votação }\end{array}$} & \multirow{8}{*}{$\begin{array}{c}\text { Não } \\
\text { implementada } \\
\mathrm{S}\end{array}$} & Ausência de erros nas listas eleitorais & $0 \%$ \\
\hline & & Fácil acesso dos eleitores aos centros de votação & $0 \%$ \\
\hline & & Bom preenchimento das atas eleitorais (sem erros e rasuras) & $0 \%$ \\
\hline & & Garantia do segredo de voto nas cabines & $0 \%$ \\
\hline & & Fácil identificação dos centros de votação pelos eleitores & $0 \%$ \\
\hline & & Ausência de focos de violência e intimidação de eleitores & $10 \%$ \\
\hline & & Ausência de práticas ilegais de voto como compra e coerção & $15 \%$ \\
\hline & & Eleitor informado sobre conteúdo do voto e como votar & $36 \%$ \\
\hline & \multirow{3}{*}{$\begin{array}{l}\text { Parcialmente } \\
\text { implementada } \\
\mathrm{s}\end{array}$} & Pontualidade na abertura dos centros de votação & $47 \%$ \\
\hline & & Garantia de segurança dos eleitores & $57 \%$ \\
\hline & & $\begin{array}{l}\text { Presença de material eleitoral e membros de mesa na } \\
\text { abertura dos centros }\end{array}$ & $63 \%$ \\
\hline & \multirow[t]{2}{*}{$\begin{array}{l}\text { Implementada } \\
\text { s }\end{array}$} & Mulheres e grupos minoritários presentes & $100 \%$ \\
\hline & & Rápida divulgação de resultados & $0 \%$ \\
\hline
\end{tabular}




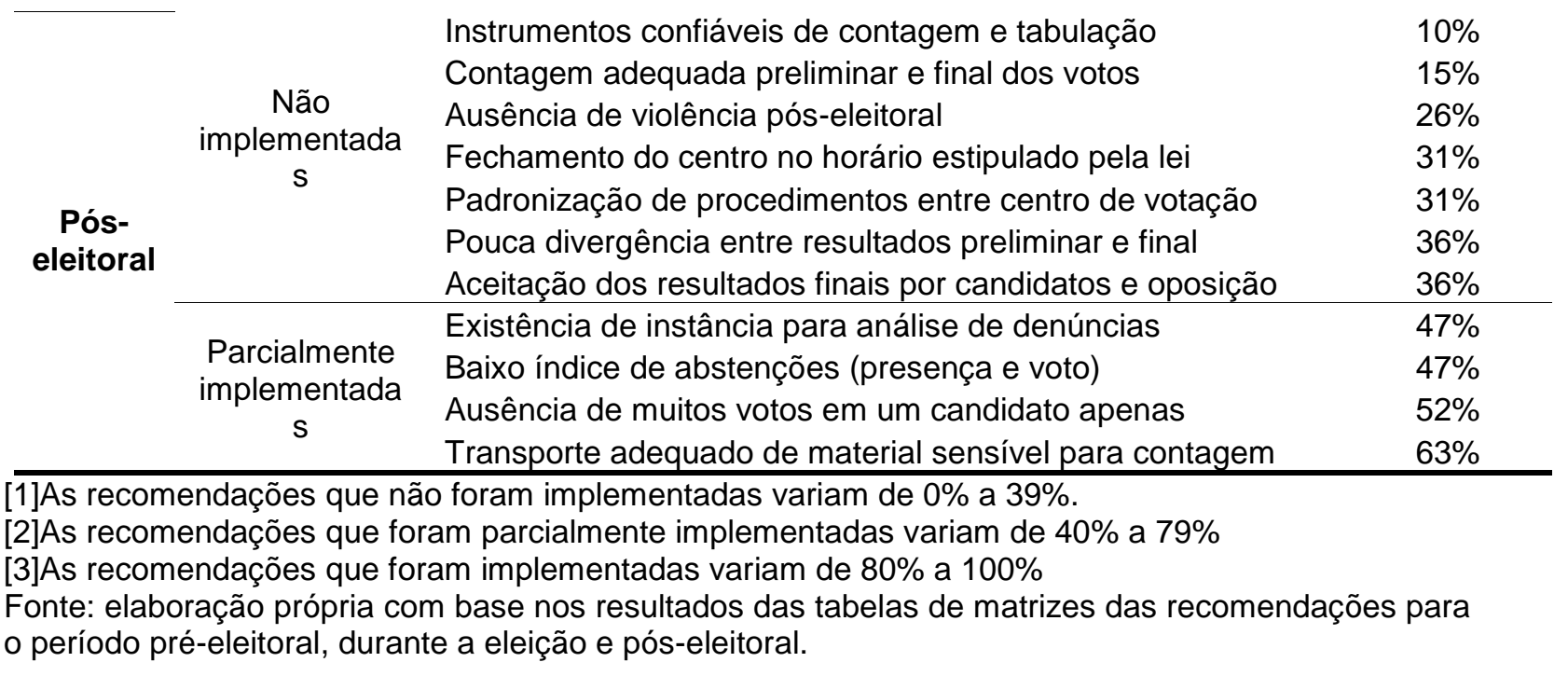

A maioria das recomendações que não foram implementadas está concentrada no dia da votação, a exemplo da persistência nos erros nas listas eleitorais. Os observadores apontaram os erros nas listas eleitorais como um fator que deveria ser melhorado, porém isso não ocorreu na maioria das eleições, em que eles estiveram presentes. Em muitas delas, os observadores relataram que viram listas sendo feitas no momento da votação a lápis (IRI, 1995; 1997) ou listas nas quais não constavam nomes de eleitores ou duplicatas de registros eleitorais.

Os erros nas listas eleitorais estão ligados ainda aos erros nos registros de votantes por parte do CEP, o que dificulta o fornecimento de credenciais eleitorais, além de ocasionar problemas como eleitores com mais de uma credencial ou má distribuição de eleitores pelos centros de votação. Nas eleições de 1990, o Ifes forneceu quatro milhões de cartões de registro em créole, como parte de seus auxílios em assistência eleitoral (IRI, 1990), como forma de evitar problemas sobre a legitimidade do processo, entre representantes de partidos políticos da oposição.

Os observadores da OEA estiveram presentes durante todo o processo de registro de eleitores das eleições de 1990. Segundo a missão, o registro foi um sucesso, apesar de irregularidades como a assinatura de alguns cartões, que foram feitas antes do período destinado a essa etapa, no calendário eleitoral (OEA, 1992). Nas eleições seguintes, "o registro de eleitores, realizado pelo CEP, foi complicado devido a erros no cálculo do tamanho da população, falta de materiais e de locais de registro, e um milhão de cartões de registro de 
eleitores desapareceram" (IRI, 1995, s.p.) ${ }^{72}$. Nesta eleição, as listas eleitorais não foram feitas de forma computadorizada, mas à mão e o número de votantes registrados nos Escritórios Eleitorais Departamentais (BEDs) não se coadunavam com aqueles do CEP (idem).

Em 2010, a lista de registro eleitoral do CEP contabilizou apenas 39 pessoas deslocadas internas, depois que um terremoto atingiu o país. Como consequência, muitas pessoas chegaram aos centros eleitorais em que elas orientadas a ir, pelo organismo eleitoral, porém não tinham seu nome na lista eleitoral do local em que estavam. "Esse foi um problema previsto, porque com milhões de residentes deslocados pelo terremoto, muitos deles sem seus cartões eleitorais, garantir que somente os eleitores habilitados votassem foi uma tarefa árdua" (Johnston e Weisbrot, 2011, p. 11).

Conforme Norris et al (2015) nas eleições gerais de 2015, uma das principais preocupações para a integridade do processo foi a massiva presença de representantes de partidos que votaram em qualquer centro eleitoral, de modo que a falta de uma lista adequada com o nome de todos os votantes, contribuiu para a existência de votos duplicados.

"Uma comissão do governo designada para rever a eleição examinou
uma amostra das folhas de registro e descobriu que apenas $8 \%$
estavam livres de erros. Trinta por cento mostravam eleitores que não
apareciam nas listas de eleitores e quase metade das folhas
apresentaram eleitores que votaram com números de identificação
incorretos. Como consequência, no segundo turno das eleições, a
participação de eleitores caiu para apenas $18 \%$ " (idem, p. 26).

Outro ponto importante do dia da votação, que não se modificou foi o fato de que os eleitores, mesmo nas eleições mais recentes, têm dificuldade na hora de chegar aos locais de votação devido às más condições das rodovias e outras vias de acesso. Em 2015, as eleições foram realizadas após a passagem de uma chuva, fazendo com que áreas, sobretudo na parte rural do país fossem afetadas. Alguns observadores relataram que pessoas de idade mais avançada não conseguiram chegar aos locais de votação (OEA, 2015).

Entre aqueles itens que não mudaram mesmo com as constantes recomendações feitas pelos observadores está também a inexistência de um organismo eleitoral independente. O convite à observação internacional é

\footnotetext{
72 Segundo Nelson (1998), foram, na verdade, 1,2 milhões de cartões de registro de eleitores, dos 4,2 milhões que haviam sido impressos; fato que gerou, inclusive, queixas de partidos políticos de que houvera irregularidades promovidas pelo organismo eleitoral.
} 
realizado, muitas vezes, com o objetivo de garantir a eficiência do trabalho desenvolvido pelo Conselho Eleitoral Provisório (CEP), uma vez que sua estrutura organizacional muda a cada nova eleição. A presença dos observadores seria uma forma de validar sua atuação, pois o CEP não é (até os dias atuais), um organismo independente ${ }^{73}$.

Também merece destaque no período pré-eleitoral, o fornecimento de credencial aos eleitores, que não melhorou. A massiva presença de representantes de partidos políticos, os mandataires, que acompanham as eleições de dentro dos centros eleitorais, contribui para que haja fraude, visto que muitos deles tentam votar em mais de um centro eleitoral, com credenciais diferentes (OEA, 2000; 2015). Esse problema se aplica principalmente aos mandataires, como parte das estratégias dos partidos políticos, de manipular o processo eleitoral no dia da eleição.

Também merece destaque a garantia do segredo de voto que apareceu como uma recomendação em todos os relatórios analisados, sendo o problema mais apontado pelos observadores e que, até as últimas eleições, não havia se modificado.

Segundo Carroll e Davis-Roberts (2013) e Norris (2013b), é universalmente aceito que o segredo de voto seja algo essencial para a garantia da livre expressão dos eleitores, protegendo-os de coações, intimidação e tentativas de compra de votos, além de manter a integridade do processo como um todo.

O segredo de voto aparece no Pacto Internacional de Direitos Civis e Políticos das Nações Unidas, como uma prática que deve ser garantida em processos eleitorais realizados em países membros da Organização, no entanto, o significado de sistemáticas falhas em assegurar o voto secreto pode variar acentuadamente em cada país. Há os casos, por exemplo, de eleições ocorridas na Espanha, entre 2001 e 2004, em que falhas correntes em assegurar o segredo de voto não implicaram em prejuízos para a qualidade do processo eleitoral. O mesmo foi observado em referendo no Sudão do Sul, de 2011. Porém, "em contextos políticos caracterizados por intimidação, medo, ou compra de votos em larga escala, falhas em assegurar o voto secreto podem obviamente

\footnotetext{
${ }^{73}$ Cf. Quadro 7.
} 
resultar em eleições fatalmente fraudulentas" (Carroll e Davis-Roberts, 2013, p. 93).

Para Donno (2013b), a existência de eleições regulares conduzidas com segredo de voto, sem fraude e, cujos resultados representam a vontade da população é, junto à garantia de campanha dos candidatos em disputa, os principais fatores que diferenciam o autoritarismo eleitoral (Schedler, 2002) de uma democracia eleitoral (Freedom House, 2016). Nas palavras de Donno (2013b, p. 18), “a transição democrática implica uma melhoria profunda na conduta eleitoral tal que as cédulas estejam seguras, os resultados das eleições representam a vontade popular e os partidos competem em condições de igualdade".

No caso do Haiti, um país extremamente vulnerável a pressões externas em seus processos eleitorais, a observação não contribuiu para o aperfeiçoamento do segredo de voto nos últimos anos (idem). Esse baixo impacto poderia ser explicado, em parte, pelo fato de que há uma série de interferências ilegais (intimidação, coação, compra de voto etc) nos processos eleitorais analisados, que, segundo a autora, tem efeito negativo na democratização (ibidem).

Segundo Norris (2012), em democracias que passaram por recentes transformações de regime, os pleitos tendem a falhar em qualquer uma das fases do ciclo eleitoral, devido ao "menu de manipulação" (Schedler, 2002), o que leva a que continuem se frustrando em sua tentativa de atender normas democráticas internacionais de boa governança eleitoral.

Esse menu de manipulação tipicamente inclui técnicas empregadas durante a fase de campanha (tais como má administração de registro de eleitores e gerrymandering dos limites dos distritos eleitorais e maior financiamento para um ou outro partido e desigual acesso aos recursos midiáticos), no dia da votação (fraude, compra de votos, assédio de leitores e cédulas previamente preenchidas) e no período imediatamente posterior (divergências na contagem e anulação de resultados finais) (idem).

Hyde (2006) também chama atenção para o fato de que eleições nas quais há identificação de manipulações ou fraude, diminuem a confiança pública e credibilidade das instituições eleitorais e processos, além de fortalecer 
sentimentos de insatisfação com a performance democrática, levando à diminuição da legitimidade desses regimes.

Hoyos (2014) acrescenta que os casos mais clássicos na região latinoamericana incluem o preenchimento fraudado de cédulas, alterações na lista de votantes e a intimidação de candidatos e eleitores. Para ela, isso afeta diretamente a liberdade dos eleitores de ir e vir dos centros de votação, além de influenciar em suas escolhas, ou seja, se um cidadão percebe que a eleição é injusta, ele provavelmente não irá participar do processo eleitoral.

Cabe acrescentar que a manipulação é mais provável de ocorrer sob determinadas condições, que incluem: eleições altamente competitivas; sistema partidário com fraca institucionalização; oposição fraca ou fragmentada; partido incumbente com maioria no poder legislativo (idem).

A aceitação dos resultados também é outro ponto que ainda permanece uma recomendação importante nos relatórios e que não teve muita melhora ao longo dos anos. Hartlyn, McCoy e Mustillo (2008) citam os casos das eleições fundacionais de 1990 como um exemplo de processo que foi tecnicamente falho, porém seus resultados não foram contestados. Já as últimas eleições não tiveram seus resultados aceitos, deixando o país imerso em uma grave crise política, que só será resolvida com a realização de novas eleições gerais proximamente.

Em se tratando de uma democracia eleitoral (Carothers, 2002; Hartlyn e McCoy, 2006 e Hartlyn, McCoy e Mustillo, 2008), é mais difícil que a boa governança eleitoral se consolide, sobretudo, porque as capacidades estatais nesses casos são menores, a exemplo da forte politização da composição dos membros do organismo eleitoral. No caso haitiano, o que se pode observar é que essa é uma característica que tem perdurado ao longo dos anos, uma vez que o CEP não é um organismo eleitoral independente.

Apesar de sua composição heterogênea, que contempla vários setores da sociedade, são frequentes as renúncias e acusações entre membros do CEP, além das críticas à forma como as eleições são conduzidas. O CEP recebe muitas reclamações de candidatos que se sentem prejudicados com relação, por exemplo, ao seu tempo de exposição na mídia, argumentando que há beneficiamento de um ou outro candidato. Sua insatisfação com essas e outras 
questões relativas ao CEP foram muitas vezes refletidas por seus apoiadores nas ruas, através de atos violentos.

Há ainda a questão do número de eleitores que votam que varia desde $70 \%$ da população votante, a menos de $20 \%$, mas que não melhoraram. No caso dos cidadãos que vão às urnas, há diferenças ainda na proporção de votantes nas eleições legislativas e parlamentares, das presidenciais, sendo as taxas de participação nas eleições presidenciais, maiores que aquelas observadas nos demais pleitos.

Tabela 12 - Visão geral da taxa de participação popular nas eleições legislativa e presidenciais no Haiti, 1990-2015

\begin{tabular}{cccccr}
\hline Tipo de eleição & Ano & $\begin{array}{c}\text { Porcentage } \\
\mathbf{m} \text { de } \\
\text { votantes }\end{array}$ & $\begin{array}{c}\text { Total de } \\
\text { votos }\end{array}$ & $\begin{array}{c}\text { Total de } \\
\text { registros }\end{array}$ & População \\
\hline \multirow{2}{*}{ Legislativa } & 2015 & $17,80 \%$ & $1,046,516$ & $5,871,450$ & $10,110,01$ \\
& 2006 & $28,30 \%$ & $1,000,314$ & $3,533,430$ & $8,282,968$ \\
& 2000 & $60 \%$ & $2,547,000$ & $4,245,384$ & $7,841,574$ \\
& 1995 & $31,10 \%$ & $1,140,523$ & $3,668,049$ & $7,184,000$ \\
& 1990 & $50,20 \%$ & $1,640,729$ & $3,271,155$ & $6,625,000$ \\
\hline \multirow{2}{*}{ Presidencial } & 2015 & $28,80 \%$ & $1,680,697$ & $5,835,295$ & $10,110,01$ \\
& 2011 & $22,40 \%$ & $1,053,733$ & $4,712,693$ & $9,719,932$ \\
& 2006 & $59,30 \%$ & $2,093,947$ & $3,533,430$ & $8,282,968$ \\
& 2000 & $78,30 \%$ & $2,871,572$ & $3,668,049$ & $7,841,574$ \\
& 1990 & $50,20 \%$ & $1,640,729$ & $3,271,155$ & $6,486,000$ \\
\hline
\end{tabular}

Fonte: Ifes, 2016.

Gráfico 2 - Porcentagem no número de votantes nas eleições haitianas, por ano e tipo de eleição 


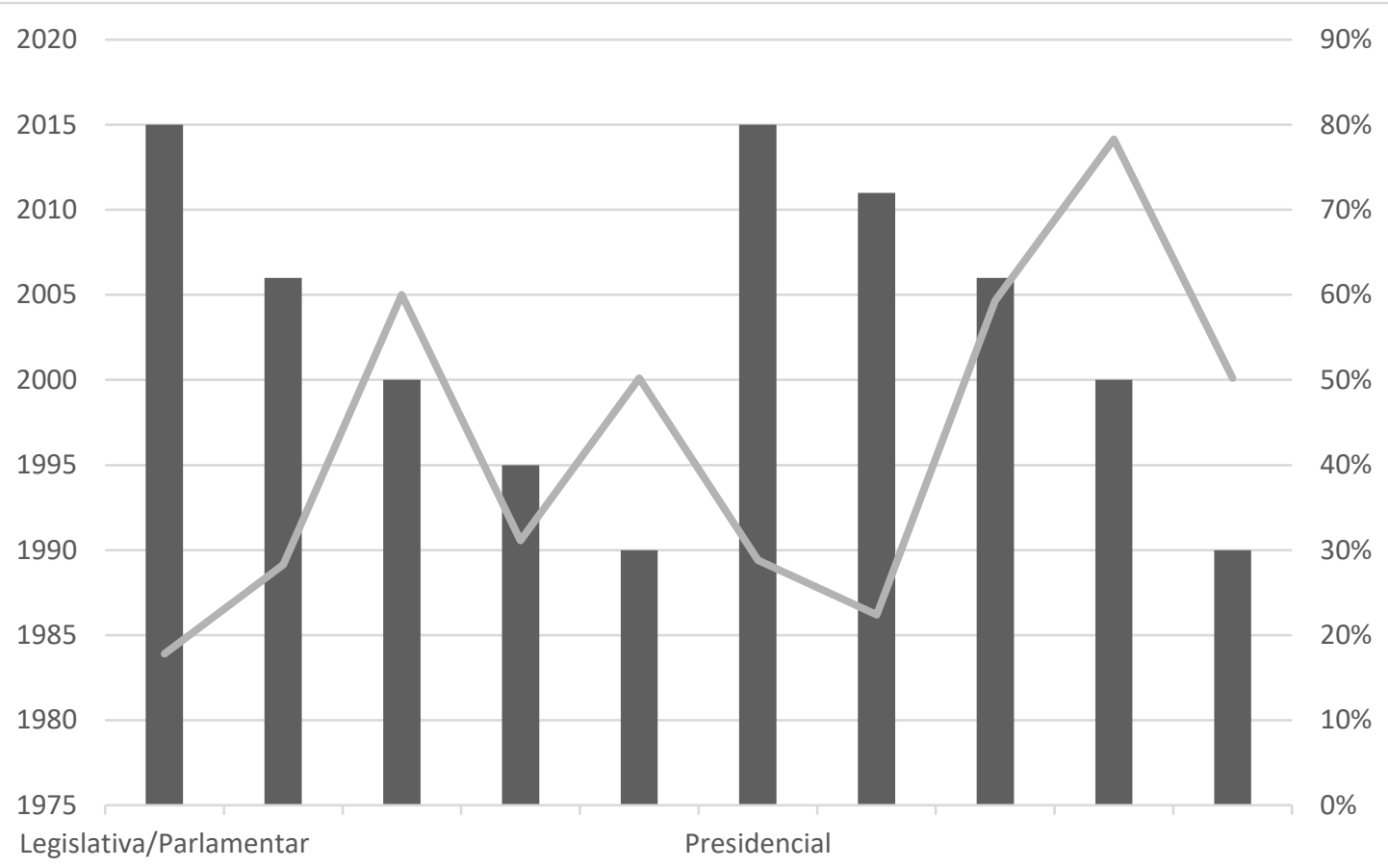

Fonte: Elaboração própria com dados do Ifes, 2016.

É importante mencionar que os relatórios das missões têm frequentemente citado as campanhas governamentais de conscientização como um importante meio de superar o grande número de abstenções, que varia em cada eleição. O IRI observou que nas eleições de 1990, a educação sobre o voto teve bastante impacto na conscientização da população sobre o registro de voto. Segundo os observadores, o CEP utilizou meios como os anúncios no rádio e televisão, pôster, artigos de jornais e outros meios para cativar a população, sendo que, a televisão e o rádio se mostraram mais eficientes nessa tarefa, devido grande número de analfabetos no país (IRI, 1990).).

Da mesma forma, nas eleições de 2010, além da utilização de recursos mais tradicionais,

“... outros métodos de conscientização e educação também foram usados, incluindo spots de rádio e TV, cartazes e folhetos, e anúncios de megafones nos mercados e outros locais públicos. No entanto, a percepção geral do impacto real destas medidas sobre a participação dos eleitores foi, na melhor das hipóteses, mista. De acordo com observadores de missões, estas medidas foram aplicadas de forma desigual nos departamentos" (OEA/Caricom, 2010, p. 26).

A realização de campanhas de conscientização foi uma recomendação implementada ao longo do período de análise, e está localizada na fase préeleitoral. No dia da votação só houve uma recomendação implementada, que na verdade, é mais um reforço à realização de eleições com a presença de 
mulheres $^{74}$ e grupos minoritários. A recomendação trata não somente na participação de mulheres e grupos minoritários como eleitores, mas também, como oficiais de sessão eleitoral e outros espaços que possam ser ocupados na organização e condução das eleições.

A OEA, em especial, passou a incentivar a promoção da participação de mulheres em processos eleitorais e em suas missões esse é um dos aspectos que tem crescido em importância nos últimos anos, constituindo-se em um dos princípios contidos na Carta Interamericana.

Em 2010, a Organização deu especial atenção ao papel das mulheres no processo eleitoral, uma vez que, essa categoria aparecia de forma esparsa nos relatórios anteriores. Segundo os observadores, "pela primeira vez na história do Haiti, duas dos dezenove candidatos à presidência eram mulheres: Mirlande Manigat e Anne Marie Josette Bijou." (OEA/Caricom, 2010, p. 30).

Além disso, a promoção da segurança dos eleitores também foi um aspecto bastante apontado pelos observadores e que foi aprimorado parcialmente nas últimas eleições, com a maior participação da Minustah auxiliando o organismo eleitoral. O mesmo pode ser colocado para o caso do transporte de material sensível.

Os observadores do IRI, relataram que para as primeiras eleições realizadas no país após o fim do período autoritário, a divulgação de resultados e o transporte de material sensível eram realizados de todas as maneiras possíveis. Os resultados eram enviados por frequências de rádio, mensagens, cabo ou telefone. Já as cédulas eram transportadas por meio dos transportes oficiais fornecidos pelo governo, veículos privados, bicicletas, tração animal, e a pé, com reforço da polícia militar, quando possível (IRI, 1990). Nas eleições seguintes, já se viram algumas mudanças com relação ao transporte de materiais que passaram a ser realizado pela Minustah, como o menor número de atrasos na abertura dos centros eleitorais, além de maior agilidade na entrega das cédulas após o fim da contagem (PVT).

Por fim, na fase pós-eleitoral não houve implementação das recomendações, visto que muitos problemas ainda ocorrem na contagem e

\footnotetext{
${ }^{74}$ As MOEls examinam a participação de eleitoras, candidatas e representantes eleitas ao longo do processo eleitoral.
} 
tabulação de votos, além da insatisfação com resultados, por parte de candidatos derrotados.

\subsection{Considerações finais}

O Haiti possui uma longa tradição no recebimento de missões de monitoramento internacionais, que, no entanto, têm tido pouco impacto tanto na sua atuação, quanto nas recomendações que fazem, com vistas a melhoria da qualidade dos processos eleitorais no país.

Porém, se considerarmos que a observação tem tido algum sucesso em áreas específicas, como a capacitação de membros dos centros eleitorais e no fornecimento de credenciais de identificação dos eleitores, além de contribuir para a minimização do risco de fraudes ou manipulações, ao longo do processo eleitoral, ela tem se mostrado algo fundamental para o caso haitiano. Em outras palavras, ainda que os observadores não tenham conseguido elevar a qualidade das eleições, sua presença contribuiu para a melhoria de aspectos pontuais, que só foram realizadas após recomendações.

Soma-se a isso ainda o argumento levantado por Kelley (2012). Segundo a autora, há países em que a observação tende a ter menor impacto, porque os próprios governos não possuem capacidade governativa suficiente para a condução do processo eleitoral. Eles podem ter carências de recursos básicos de infraestrutura, lutam para imprimir todas cédulas eleitorais e não suas listas eleitorais constantemente contêm erros.

O Haiti se enquadra nesse quadro e assumir que a observação seja ineficiente nesse caso é desprezar as próprias dificuldades intrínsecas à condução do processo eleitoral, por parte dos governantes. É claro que a observação tem suas limitações, de recursos, tempo, pessoal, entre outras, mas consideramos que ela contribuiu, ainda que de forma tímida, para a melhoria dos pleitos haitianos, sendo sua presença desejável, uma vez que sua ausência, poderia implicar, possivelmente, no recrudescimento de algumas mudanças já alcançadas. 


\section{RESISTÊNCIA E PERSISTÊNCIA: IMPACTO DAS MISSÕES DE OBSERVAÇÃO ELEITORAL NO PROCESSO ELEITORAL DO MÉXICO}

\subsection{Introdução}

País de grande extensão territorial e população, o México realiza eleições periódicas com voto compulsório, porém, nem mesmo essa obrigatoriedade foi capaz de diminuir a desconfiança dos cidadãos mexicanos com a política. Em parte, essa situação é resultado de mais de setenta anos de um sistema de partido único, que manipulou os processos eleitorais realizados no país.

Por outro lado, organizações de defesa dos direitos humanos, também relacionadas às eleições, se tornaram mais atuantes no país, com o auxílio, inclusive de atores internacionais.

Assim, a política tem se modificado aos poucos, incluindo novos elementos em seus processos eleitorais, a exemplo do convite à observação internacional, que tem estreita relação com as reformas na organização dos nos processos de escolha popular realizados no país.

A observação internacional de eleições foi inicialmente combatida pelo governo de Salinas, que mais tarde, vendo oportunidades econômicas e sociais na esteira da observação eleitoral internacional, autorizou a atividade em território mexicano, remexendo as antigas estruturas engessadas da política, como é explicado nas próximas seções.

\subsection{Caracterização do México e sua cultura política}

O alto nível de desencantamento dos cidadãos mexicanos com a política se deve a uma série de episódios, que foram cada vez mais diminuindo a capacidade de resposta política do governo: divisões dentro do PRI, fraude eleitoral maciça de 1989, acusações de corrupção contra o ex-presidente Carlos Salinas de Gortari, o levante de Chiapas, o assassinato do candidato presidencial do PRI; todos foram fatores que ajudaram a diminuir a confiança popular no sistema mexicano. Mais recentemente, a guerra contra os traficantes de drogas contribuiu para o aumento da falta de empatia com relação à política do país. 
Estes escândalos e décadas de governo autoritário podem explicar por que uma maioria dos mexicanos expressa pouco ou nenhum interesse pela política, não obstante o temporário interesse em torno das eleições presidenciais históricas de 2000, em que houve alta na participação popular, com mais de 50\% dos eleitores presentes no dia da votação (Latinoamericana, 2007).

O México sob a liderança do PRI era um regime autoritário que buscava conter e limitar a participação popular na política. A cultura política do México continua a refletir essa limitação ainda nos dias atuais, visto que o país possui baixos níveis de participação política e de ativismo (idem).

No entanto, com a erosão da hegemonia do PRI, que teve início ainda nos anos 1980, o que se vê é a mudança radical na base da classe social dos partidos no país. Os mexicanos mais ricos e aqueles de classe média abandonaram o PRI em massa, entre os anos 1989 e 2000. Em 2000, o PRI dependia principalmente do apoio dos mexicanos de classe baixa na área rural (Fox, 1996).

Conforme Mainwaring e Hagopian (2005) o maior desafio enfrentado por regimes de partido dominante é uma possível derrota por forças da oposição, porém isso é pouca provável, uma vez que a arena eleitoral está enviesada. De um lado, há muitas vantagens para o partido no poder, que detém o controle do aparato estatal, além de instrumentos patronais para evitar que eleitores votem em candidatos da oposição. De outro, o partido no poder controla as instituições eleitorais, de modo que ele pode criar leis e regras que impeçam a entrada de novos partidos, na disputa política e, caso necessário, podem ainda, manipular listas de eleitores, procedimentos relativos à organização das eleições e, até mesmo, o resultado dos pleitos.

Assim, a democratização de autocracias de partido único requer que os eleitores votem nos candidatos da oposição, ao mesmo tempo em que o partido incumbente deve ceder o controle do processo eleitoral, de forma que alguma forma de Estado de Direito possa se estabelecer, ao longo das eleições (idem).

Durante a maior parte do longo reinado do PRI, as eleições foram mais celebrações nacionais do poder do PRI do que campanhas eleitorais competitivas. No entanto, dois eventos levaram a quebra dessa tradição. Em primeiro lugar, a garantia de independência ao Instituto Federal Eleitoral (IFE) mexicano, após reforma eleitoral de 1996, foi um ponto de inflexão no processo 
de democratização mexicano, uma vez que, garantiu a credibilidade dos processos eleitorais, sobretudo, porque retirou o controle do organismo eleitoral, evitando qualquer tipo de manipulação a seu favor.

Depois, a campanha presidencial de 2000 rompeu com a tradição de patronagem até então dominante no México. Foi a primeira vez em que foram estabelecidas regras claras sobre o financiamento de campanhas, evitando que o partido dominante saísse na frente dos demais, na corrida presidencial. 0 acesso aos meios de comunicação pelos partidos foi mais equitativo do que nunca. Embora os candidatos do PRI ainda dispusessem de maior vantagem, o campo de jogo era agora mais nivelado do que se comparado a eleições anteriores.

$\mathrm{Na}$ campanha de 2000 , os três principais partidos políticos do México apresentaram uma ampla gama de opções ao eleitorado. O PRI, sob o slogan da campanha "O poder servirá ao povo", representou o legado da Revolução Mexicana e do nacionalismo. Já o PAN compartilhou o entusiasmo do PRI pelo neoliberalismo e reformas, sendo a opção pela democratização, ao passo que o PRD criticava as reformas econômicas realizadas nos anos anteriores, e criticava, inclusive, a adesão do país ao Nafta.

No entanto, embora o México possa ser caracterizado como uma democracia eleitoral, ele ainda não atingiu o Estado de Direito. Embora interligados, a realização da primeira não garante necessariamente o último. $\mathrm{A}$ democracia eleitoral significa que há no país a escolha de representantes políticos, mediante eleições competitivas, nas quais os cidadãos podem expressar livremente suas preferências por candidatos e políticas. O Estado de Direito implica que os cidadãos têm meios eficazes de proteger seus direitos fundamentais contra tentativas do governo ou de outros cidadãos de retirá-los (Haber et al, 2008).

O déficit de democracia mexicano se expressa, conforme tabela a seguir:

Tabela 13 - Satisfação com a democracia no México, 1995 - 2015*

\begin{tabular}{lrrrrr}
\hline \multirow{2}{*}{ México } & \multicolumn{5}{c}{ Anos } \\
\cline { 2 - 6 } & $\mathbf{1 9 9 5}$ & $\mathbf{2 0 0 0}$ & $\mathbf{2 0 0 5}$ & $\mathbf{2 0 1 0}$ & $\mathbf{2 0 1 5}$ \\
\hline Muito satisfeito & $3 \%$ & $11 \%$ & $4 \%$ & $6 \%$ & $4 \%$ \\
$\begin{array}{l}\text { Bastante } \\
\text { satisfeito }\end{array}$ & $19 \%$ & $25 \%$ & $15 \%$ & $22 \%$ & $15 \%$ \\
\hline
\end{tabular}




\begin{tabular}{lrrrrr}
\hline Não muito & $37 \%$ & $40 \%$ & $52 \%$ & $42 \%$ & $42 \%$ \\
satisfeito & $33 \%$ & $21 \%$ & $28 \%$ & $26 \%$ & $37 \%$ \\
Nada satisfeito & $7 \%$ & $2 \%$ & $1 \%$ & $3 \%$ & $2 \%$ \\
Não sabe & $1 \%$ & $0 \%$ & $0 \%$ & $1 \%$ & $1 \%$ \\
Não respondeu & 1.204 & 1.166 & 1.200 & 1.200 & 1.200 \\
\hline Amostra &
\end{tabular}

* Resposta à pergunta: Em geral, você diria que está muito satisfeito, bastante satisfeito, não muito satisfeito, nada satisfeito ou não satisfeito com o funcionamento da democracia em (país)?

Fonte: Latinobarometro, 2015.

Como se vê, a grande parte dos entrevistados declararam-se "não muito satisfeitos" e "nada satisfeitos" com o funcionamento da democracia no país entre $60 \%$ e $80 \%$-, embora proporção não desprezível assume estar "mais do que satisfeita" - entre $15 \%$ e $25 \%$.

O México ainda está no caminho rumo a uma democracia liberal. De um lado, o aumento da competição e pluralismo político nas eleições de 2000 - com a eleição de um presidente do PAN e a manutenção de maioria parlamentar do $\mathrm{PRI}$-, alterou as relações de poder dentro do governo mexicano. Porém, houve pouco progresso em áreas como direitos humanos e combate à corrupção (idem).

Por fim, a abertura do país à observação de eleições realizada por organizações internacionais tem contribuído para o aperfeiçoamento das instituições políticas mexicanas, em especial aumentando a garantia de que não haverá fraudes nos centros eleitorais no dia da votação.

\subsubsection{Da soberania à aderência a normas internacionais democráticas}

Se de um lado, as eleições sempre foram um componente presente na vida política mexicana, a competição, por outro lado, esteve sempre ausente. Seu processo de democratização começou com o desenvolvimento de processos eleitorais livres e justos e ampliação da competição eleitoral.

Segundo Lean (2012), "de 1929 a 2000 o país foi governado somente por um único partido. Durante esse período de setenta e um anos, o Partido Revolucionário Institucional (PRI) e seus antecessores nunca perderam uma eleição presidencial” (p. 59). Não somente isso, como o PRI manteve até 1982, 
metade das cadeiras na Câmara de Deputados e, em 1988, ele controlava ao menos $80 \%$ dos assentos no Senado (idem).

Embora as origens do PRI estejam ligadas à Plutarco Calles (1924-1928), fundador do Partido Nacional Revolucionário (PNR), que mais tarde se transformaria no PRI, é com Lázaro Cárdenas (1934-1940) que toma forma o sistema de partido dominante com estrutura política corporativa, que seria a base do PRI anos depois. Em 1938, Cárdenas reuniu agricultores, industriais, professores, funcionários públicos etc, em torno de uniões trabalhistas, ligadas ao partido, que foi renomeado para Partido da Revolução Mexicana (PRM).

Para Roxborough (1996, p. 265), “ao fim da presidência de Lázaro Cárdenas - trinta anos após o início da revolução mexicana - a classe trabalhadora estava organizada, como nunca antes, numa grande e poderosa confederação sindical, a Confederação de Trabalhadores do México (CTM). Já os camponeses foram reunidos na Confederação Nacional Camponesa (CNC).

Essa estrutura deixou de fora o setor privado, que fundou o Partido da Ação Nacional (PAN), ainda em 1938, e representava não são somente os interesses empresariais como aqueles da Igreja Católica. Porém, "embora o PAN tenha competido regularmente nos processos eleitorais realizados no período, ele nunca ganhou mais de $20 \%$ dos votos necessários para ocupação de cargos (Lean, 2012).

O autoritarismo eleitoral mexicano teve como características principais a existência de uma multiplicidade de partidos, competindo minimamente em eleições regulares, porém com violações a princípios liberal-democráticos, a exemplo da liberdade e integridade dos processos. Essas são as mesmas características exaltadas por Schedler (2002), ao indicar como eram a maioria das autocracias eleitorais, que emergiram com a Terceira Onda. Nesses casos, a manipulação aparece como um instrumento na mão do partido incumbente, para manutenção de sua posição no cenário político.

No entanto, esse jogo corrupto acabou por facilitar o gradual processo de democratização através de eleições, no México. Com esse pensamento, o autor revitaliza a tese de Huntington (1994) ao afirmar que nesses regimes, sua permanência no poder não é algo seguro. Sempre sofrem com as incertezas do processo eleitoral e, por isso, usam de estratégias manipulativas para sua manutenção no poder. 
Segundo Pastor (1999), no caso das democracias liberais de países desenvolvidos, há pouca preocupação internacional com a conduta do processo em si, tendo em vista que suas instituições eleitorais são consideradas como algo consolidado. Porém, em se tratando de países em desenvolvimento, há menor interesse nas instituições, e mais no questionamento sobre se esses países possuem capacidade governativa suficiente, para evitar fraudes, ao mesmo tempo em que monitoram práticas de boa governança, como campanhas de financiamento, por exemplo.

O caso mexicano representa uma das formas de ditadura mais duradouras do século $X X$, quando o país, sob a regra do $P R I$, se manteve ano após ano como uma autocracia eleitoral (Schedler, 2013). "Na mesma proporção que diminuiu o número de ditaduras militares, vimos a ascensão de novas variedades de autoritarismo eleitoral" (idem, p. 4), muitos deles, inclusive, nasceram de transições de partidos únicos.

No caso mexicano, a ascensão de novos partidos de oposição nos anos 1980 e a perda da maioria do Congresso pelo PRI em favor do Partido da Revolução Democrática (PRD) e do PAN, do presidente Vicente Fox, eleito em 2000 e que foi o "primeiro líder na história mexicana a pacificamente receber o poder de um grupo político rival (Greene, 2007). Da mesma forma, "a vitória de Fox foi ratificada pelo Tribunal Eleitoral e de Poder Judicial Federal (TEPJF) e não pelo Colégio Eleitoral de compra e venda de novos membros do congresso ${ }^{75}$, que por muitos anos ratificaram suas próprias eleições" (Eisenstadt, $2003)^{76}$.

Em contraste com as eleições de 1988 imersas em tanta controvérsia e denúncias, que mesmo quando Carlos Salinas assumiu a presidência, ainda persistiam dúvidas sobre a legitimidade de sua eleição ${ }^{77}$. Sobretudo, porque 0 processo foi conduzido por uma comissão eleitoral liderada pelo secretário do Interior, que era do PRI, quando uma série de irregularidades surgiram, como

\footnotetext{
75 Ver Magaloni (2006).

${ }^{76}$ Apesar de o PRI dominar o cenário político como um partido único, durante muito tempo, houve preocupação de seus representantes em manter estruturas minimamente parecidas com aquelas de regimes democráticos, sem, no entanto, contarem com processos típicos de uma democracia. 77 Salinas recebeu aproximadamente $50 \%$ dos votos, sobre o rival Cuauhtémoc Cárdenas, do Front Nacional Democrático (FND), depois transformado no PRD.
} 
centenas de cédulas de voto queimadas flutuando nos rios do país e um apagão nos computadores destinados à contagem de votos (idem).

Magaloni (2006) diz que as fraudes das eleições ocorriam, sobretudo, em áreas rurais, pois partidos da oposição não tinham tantos recursos para estar nesses locais, e acabavam por não enviar seus representantes para observar o desenrolar do processo. Muitos desses partidos, inclusive, não possuíam candidatos no campo. Ao contrário das jurisdições políticas urbanas, em que a margem de manobra do PRI para cometer fraudes eleitorais era mais restrita, já que a oposição estava mais presente para monitorar os centros eleitorais.

Conforme Diamond (2004) não se pode atribuir à diminuição do poder do PRI somente a maior utilização de estratégias de manipulação, pois, segundo o autor, líderes autoritários tendem a utilizar métodos de repressão, coação, intimidação e fraude, somente quando estão vulneráveis, e não, quando sua posição política está garantida nas urnas, o que não era o caso à época.

Assim, somado a isso, tem-se o fato de que o México, e outros países da região, atravessavam uma severa crise econômica, que impactava suas escolhas políticas. Sob a gestão de López Portillo (1976-1982), os gastos públicos cresceram exorbitantemente após consecutivos pedidos de empréstimos para exploração de reservas de petróleo recém descobertas. Como consequência, quando ocorreu a queda no preço de barris do petróleo, em 1981, o país estava muito endividado.

A crise permitiu, de um lado, maior pressão para ampliação da participação política, ao mesmo tempo em que o PRI via sua credibilidade internacional diminuir a cada dia mais. As eleições deixavam de ser 0 instrumento tradicional do PRI para legitimar as decisões tomadas dentro do partido e se transformaram no canal manifesto da sociedade, como nunca antes visto, para discussões sobre a legislação, as instituições e os procedimentos políticos envolvidos nas eleições (Gibbran, 2010).

Em 1986, as eleições locais de Chihuahua, estado localizado na fronteira dos Estados Unidos, contribuiu ainda mais para a insatisfação popular com a forma como os processos eleitorais vinham sendo realizados. Nessa eleição, quando o PAN se mostrou um desafio à altura do PRI, o partido dominante empregou uma série de fraudes para assegurar que a oposição não vencesse a disputa. Urnas com cédulas preenchidas para o PRI, coerção de eleitores, erros 
na contagem de votos para o PAN, todas essas estratégias adaptativas de manipulação levaram à indignação dos eleitores, que tomaram as ruas e chamaram a atenção para o processo eleitoral. Chand (2001) diz que a situação incentivou o crescimento das demandas públicas pela integridade dos pleitos e reformas na administração eleitoral, não só em Chihuahua, mas também no resto do país ${ }^{78}$.

Eisenstadt (2003) complementa que os panistas (partidários do PAN), passaram a focar suas ações nos processos eleitorais subnacionais, como uma forma de pressionar o PRI no caminho da democratização. Assim, ao explorar potências locais e forçar o PRI a aceitar resultados de eleições locais ${ }^{79}$ e, depois, governamentais, alcançaram impacto nacional para suas conquistas locais. Também forçaram outros partidos de oposição, a exemplo do PRD, a tentar o mesmo.

Sobre o segundo ponto, Chand (1997) argumenta que a credibilidade do partido começou a ruir também devido às escolhas econômicas de Carlos Salinas. Com sua decisão de adotar um modelo orientado para a exportação com maior integração com os Estados Unidos, o então presidente fez com que o processo eleitoral mexicano se tornasse mais passível de escrutínio internacional, que em outras épocas (idem).

Em 1991, as eleições legislativas não contavam ainda com a presença de visitantes estrangeiros, porém, observadores domésticos da, mais tarde, denominada Aliança Cívica, receberam financiamento externo (Lean, 2007), como resultado da expansão do suporte de organizações internacionais à promoção da democracia, que encorajaram o surgimento de várias organizações domésticas de observação. Os fundos provinham da Usaid ${ }^{80}$ e do NED ${ }^{81}$, sendo

\footnotetext{
78 Robert Pastor, um dos principais representantes do Centro Carter na América Latina, visitou Chihuahua nas eleições de 1986, a pedido de um colega acadêmico mexicano. Durante sua observação informal, ele presenciou múltiplos incidentes de manipulação eleitoral, de modo que seu interesse pessoal pelos pleitos mexicanos contribuiu, além de outros fatores, para o envolvimento prematuro da organização no monitoramento internacional das eleições no país (Lean, 2012).

${ }^{79}$ Hartlyn, McCoy e Mustillo (2008) argumentam que uma eleição só é considerada legítima se todos os partidos políticos com maior destaque aceitam o processo e respeitam seu resultado. ${ }^{80} \mathrm{~A}$ Usaid é um órgão do governo dos Estados Unidos responsável pela distribuição da ajuda externa. Foi criada em 1961, durante a presidência de John F. Kennedy (1961-1963).

81 O NED foi elaborado em 1970 por um grupo de políticos e aca estadunidenses, com o objetivo de dar suporte à criação de novos partidos políticos na América, que depois também foram direcionadas a outras organizações políticas, como os observadores internacionais. Em 1983,
} 
que o último, também financiara a Participa, no Chile, e a Via Cívica, na Nicarágua.

No entanto, entre 1985 e 1991, os fundos foram destinados, em grande parte a organizações econômicas do setor privado, como a Confederação de Câmaras Nacionais de Comércio (Concanaco). Ao contrário de países como a Nicarágua ${ }^{82}$, nos quais houve pressão de Washington, para que reformas políticas internas fossem implementadas, no caminho rumo à democratização, e, assim, os incentivos fossem garantidos, no México, isso não ocorreu. A saída encontrada foi o financiamento feito exclusivamente como assistência ao desenvolvimento democrático, através do NDI e do IRI, para organizações como a Aliança Cívica ${ }^{83}$, de observação doméstica.

Assim, em 1994, as Nações Unidas começaram a trabalhar de forma intensa com a Aliança Cívica, para promoção da maior participação política da sociedade nas eleições gerais daquele ano. Não somente isso, como a chegada de Bill Clinton (1993 - 2001) à Casa Branca, influenciou diretamente nos financiamentos à promoção da democracia no país vizinho, ainda que o maior financiador continuasse sendo as Nações Unidas, através do Pnud.

Tabela 14 - Fundos recebidos pela Aliança Cívica, 1994

\begin{tabular}{lrr}
\hline Fundação & Total US\$ & $\%$ \\
\hline Pnud & $1,277,087$ & 71.2 \\
Trusteeship for Democracy & 331,764 & 18.5 \\
NED & 155,000 & 8.6 \\
Diferentes doações & 17,647 & 1.0 \\
NDI & 8,941 & 0.5 \\
Banco Mexicano de Comércio Exterior & 1,548 & 0.1 \\
Banco Obrero & 1,470 & 0.1 \\
Total & $1,793,457$ & 100.0 \\
\hline Fonte: Adaptado e traduzido de Quezada (2001).
\end{tabular}

Havia ainda o fato de que a contestação sobre a qualidade e integridade dos processos eleitorais no país passou a interessar diretamente Washington ao

Ronald Reagan (1981-1989) aprovou a incorporação do NED às iniciativas de promoção de democracia dos Estados Unidos (Carothers, 2011).

82 Segundo Pastor (1999), a presença de observadores internacionais contribuiu para que não fosse reconhecida a legitimidade, por exemplo, dos governos de Ferdinando Marcos, nas Filipinas, e Manuel Noriega, na Nicarágua, à época, tornando-os mais vulneráveis às pressões domesticas e externas.

${ }^{83}$ O interesse em receber os visitantes surgiu em 1990, porém, para o governo mexicano a vinda de estrangeiros poderia representar um custo muito alto, de modo que, a saída encontrada, foi a promoção do monitoramento pelos próprios cidadãos. Com recursos externos, a prática de observar as eleições começou a se estabelecer no país, e, a partir daí algumas ONGs e partidos locais começaram a convidar observadores estrangeiros sem o consentimento do governo. 
longo das negociações para entrada do México no Tratado Norte-Americano de Livre Comércio (Nafta). Consequentemente, as eleições presidenciais de 1994, no qual Ernesto Zedillo foi eleito, foram as mais observadas na história do país, após a abertura do país às organizações internacionais de monitoramento. Durante o processo, "foram credenciados 943 visitantes estrangeiros de 39 países, sendo que os Estados Unidos tiveram o maior número de observadores enviados, com 653 (68,6\% do total), seguidos pelo Canadá com 55 (5,8\%) e Espanha com 39 (4,1\%)" (Gibbran, 2010, s. p.).

Mesmo assim, dentro do próprio IFE, alguns funcionários se mostravam contrários à participação de estrangeiros nas eleições, porque acreditavam que isso iria comprometer a soberania mexicana. Por razões históricas, em especial as constantes intervenções dos Estados Unidos em seus assuntos domésticos, a constituição mexicana proibia estrangeiros de interferir, de qualquer forma, nas questões de interesse político do país (Lean, 2012).

Porém, para as eleições gerais de 1994, o organismo eleitoral autorizou, pela primeira vez, a participação de forasteiros no processo eleitoral do país, e criou duas categorias separadas para os observadores eleitorais: visitantes estrangeiros e observadores nacionais (idem).

É somente nas eleições de 1997, que o PRI perdeu sua maioria no Congresso e, durante o processo de escolha do novo presidente, em 2000, é que se completa a abertura democrática mexicana.

Ao mesmo tempo, ocorreu a ampliação da participação de uma série de atores internacionais de observação, com o processo de votação que levou Vicente Fox, da coalizão Alianza por el Cambio (Aliança para a Mudança) ao cargo de presidente. Naquela época, a credibilidade deste processo foi novamente uma miríade de observadores nacionais e internacionais. Mais de 30 mil observadores nacionais e 862 observadores internacionais estavam distribuídos por todo o país e acompanharam as eleições" (Santa-Cruz, 2009, p. 28).

Não obstante, o argumento à época era o de que em poucos anos o governo mexicano não exigiria observadores porque seu compromisso com normas internacionais democráticas, com relação a eleições livres e justas, aumentara. Como observa Santa Cruz (2005), nas eleições de legislativas de 2003, haviam apenas alguns poucos observadores estrangeiros, apesar de 0 
Instituto Federal Eleitoral (IFE) ter feito convites a organizações internacionais de monitoramento, há alguns meses antes.

De acordo com Recondo (2006, p. 299-300),

\begin{abstract}
"O IFE tornou-se um membro muito ativo de uma grande rede de organizações eleitorais ao redor do mundo, da Ásia às Américas, através da África e da Europa. Conferências de contrapartes do IFE foram realizadas a cada dois anos na Cidade do México. O Pnud, o Idea e a ONG internacional especializada em perícia eleitoral, Ifes, foram co-organizadoras desses eventos. Finalmente, os partidos políticos em todo o mundo e as fundações relacionadas a eles (Friedrich Hebert, Konrad Adenauer, NDI e IRI, entre outros) organizações regionais que não a UE (Mercosul, União Africana) também passaram a enviar observadores para os processos eleitorais no México".
\end{abstract}

Ao entrar na esfera de processos eleitorais mais contemporâneos vale a pena mencionar as eleições de 2006, quando pela primeira vez observadores internacionais vieram de países como: Afeganistão, Estônia, Grécia, Iraque, Lituânia, Luxemburgo, Malásia, Marrocos, Noruega, Paquistão, Eslováquia, República Checa, Filipinas, Trinidad e Tobago, Turquia, Uganda.

Mais recentemente, as eleições legislativas de 2015 receberam, por exemplo, visitantes estrangeiros provenientes da China. Esses visitantes não só se interessam por eleições em geral, mas em que eleições podem representar para eles em termos de negócios, já que muitos acordos comerciais contêm o que se poderia chamar uma "cláusula democrática" (por exemplo, o México e o acordo comercial da União Europeia). Isto obriga os países a cumprir uma série de condições a serem negociadas, para sua inclusão nos acordos, a exemplo da realização de eleições livres e justas, a intervalos regulares" (idem).

Segundo Magaloni (2006), todas as mudanças realizadas ao longo dos últimos anos, desde a democratização, até o convite à observação internacional, tiveram o incentivo zapatista, uma vez que após a irrupção das guerrilhas no sul do estado de Chiapas, em janeiro de 1994, o governo deu início a uma série de reformas eleitorais. Entre as principais mudanças, pode ser citada a independência do IFE, como organismos responsável pela organização e monitoramento das eleições. A partir daí os partidos da oposição consideraram que o problema da transparência do processo eleitoral federal estava resolvido, sendo necessário outras reformas, nos anos seguintes.

Dentro desse quadro, a observação internacional teve ao longo das últimas eleições, uma atuação importante, sobretudo, após a chegada de mais 
missões a partir de 1994, quando a atividade passou a ser regulamentada no país.

5.3 Primeiras análises: a observação eleitoral a serviço dos interesses políticos mexicanos

O índice geral de governança eleitoral do México atinge o estrato médio, com diferença significativa entre os índices da fase pré-eleitoral e pós-eleitoral, 0.72 e 0.75 , respectivamente, e o índice do dia da eleição, baixo, de 0.38. Conforme quadro e tabelas a seguir:

Quadro 8 - Índice de Governança Eleitoral, por fase de observação, México

\begin{tabular}{ccc}
\hline País & Fase & Índice \\
\hline \multirow{3}{*}{ México } & Pré-eleitoral & $0.72 \rightarrow$ Médio \\
& Dia da eleição & $0.39 \rightarrow$ Baixo \\
& Pós-eleitoral & $0.75 \rightarrow$ Médio \\
\hline
\end{tabular}


Tabela 15 - Matriz de observação para o período pré-eleitoral, México, 1990-2015

\begin{tabular}{|c|c|c|c|c|c|c|c|c|c|c|c|c|c|c|}
\hline Indicadores/Anos & $\begin{array}{l}\frac{5}{g} \\
\text { 戸 }\end{array}$ & $\begin{array}{l}\stackrel{\Xi}{g} \\
\stackrel{\sigma}{\Xi}\end{array}$ & 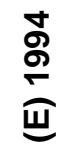 & $\begin{array}{l}\hat{\sigma} \\
\stackrel{\sigma}{\sigma} \\
\Xi\end{array}$ & $\begin{array}{l}\text { 옹 } \\
\text { ㄹ }\end{array}$ & $\begin{array}{l}\text { 옹 } \\
\text { 뜨 }\end{array}$ & 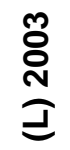 & $\begin{array}{l}\text { o̊ } \\
\stackrel{ }{N} \\
\text { 己. }\end{array}$ & $\begin{array}{l}\mathscr{8} \\
\text { N } \\
\text { ய }\end{array}$ & $\begin{array}{l}\text { ㅇ } \\
\text { 을 } \\
\text { Ð }\end{array}$ & $\begin{array}{l}\text { N } \\
\stackrel{\text { N }}{\beth} \\
\beth\end{array}$ & 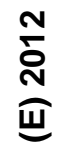 & $\stackrel{n}{\stackrel{n}{0}}$ & Número de sim \\
\hline Existência de um organismo eleitoral independente & - & $\mathrm{n}$ & $\mathrm{n}$ & $\mathrm{s}$ & s & $\mathrm{s}$ & s & s & s & s & s & s & s & 10 \\
\hline Ausência de grupos armados & - & $\mathrm{S}$ & $\mathrm{S}$ & $\mathrm{s}$ & $\mathrm{s}$ & $\mathrm{s}$ & $\mathrm{s}$ & $\mathrm{s}$ & $\mathrm{s}$ & $\mathrm{n}$ & $\mathrm{s}$ & $\mathrm{S}$ & $\mathrm{n}$ & 10 \\
\hline Respeito ao calendário eleitoral & - & $\mathrm{s}$ & $\mathrm{s}$ & $\mathrm{s}$ & $\mathrm{s}$ & $\mathrm{s}$ & $\mathrm{s}$ & $\mathrm{s}$ & $\mathrm{s}$ & $\mathrm{s}$ & $\mathrm{s}$ & $\mathrm{s}$ & $\mathrm{s}$ & 12 \\
\hline Fiscalização de financiamento ilegal de campanha & - & $\mathrm{s}$ & $\mathrm{s}$ & $\mathrm{s}$ & $\mathrm{s}$ & $\mathrm{s}$ & $s$ & $\mathrm{~s}$ & $\mathrm{~s}$ & $\mathrm{~s}$ & $\mathrm{~s}$ & $\mathrm{~s}$ & $\mathrm{~s}$ & 12 \\
\hline Coordenação efetiva de centros eleitorais & - & $\mathrm{n}$ & $\mathrm{n}$ & $\mathrm{s}$ & $\mathrm{n}$ & $\mathrm{n}$ & $\mathrm{n}$ & $\mathrm{n}$ & $\mathrm{n}$ & $\mathrm{n}$ & $\mathrm{n}$ & $\mathrm{n}$ & $\mathrm{n}$ & 1 \\
\hline Ausência de focos de violência eleitoral & - & $\mathrm{s}$ & $\mathrm{s}$ & $\mathrm{n}$ & $\mathrm{s}$ & $\mathrm{s}$ & $\mathrm{s}$ & $\mathrm{n}$ & $\mathrm{n}$ & $\mathrm{n}$ & $\mathrm{n}$ & $\mathrm{n}$ & $\mathrm{n}$ & 5 \\
\hline Capacitação de oficiais eleitorais & - & $\mathrm{s}$ & $\mathrm{s}$ & $\mathrm{s}$ & $\mathrm{s}$ & $\mathrm{s}$ & $\mathrm{s}$ & $\mathrm{s}$ & $\mathrm{s}$ & $\mathrm{n}$ & $s$ & $\mathrm{~s}$ & $\mathrm{~s}$ & 11 \\
\hline Educação cívica sobre importância do voto & - & $\mathrm{n}$ & $\mathrm{n}$ & $\mathrm{s}$ & $\mathrm{s}$ & $\mathrm{s}$ & s & $\mathrm{s}$ & $\mathrm{s}$ & s & s & $\mathrm{s}$ & $\mathrm{s}$ & 10 \\
\hline Ausência de campanhas de desmobilização de eleitores & - & $\mathrm{s}$ & $\mathrm{s}$ & $\mathrm{s}$ & $\mathrm{s}$ & $\mathrm{s}$ & $\mathrm{s}$ & $\mathrm{s}$ & $\mathrm{s}$ & $\mathrm{n}$ & $s$ & $\mathrm{~s}$ & $\mathrm{~s}$ & 11 \\
\hline Competição política & - & $\mathrm{n}$ & $\mathrm{n}$ & $\mathrm{s}$ & $\mathrm{s}$ & $\mathrm{s}$ & $\mathrm{s}$ & $\mathrm{s}$ & $\mathrm{s}$ & $\mathrm{s}$ & $\mathrm{s}$ & $\mathrm{s}$ & $\mathrm{s}$ & 10 \\
\hline Fornecimento de credenciais aos eleitores & - & $\mathrm{s}$ & $\mathrm{s}$ & $\mathrm{s}$ & $\mathrm{s}$ & $\mathrm{s}$ & $\mathrm{s}$ & $\mathrm{s}$ & $\mathrm{s}$ & $\mathrm{s}$ & $\mathrm{s}$ & $\mathrm{s}$ & $\mathrm{s}$ & 12 \\
\hline Ausência de erros no registro de eleitores & - & $\mathrm{n}$ & $\mathrm{n}$ & $\mathrm{n}$ & $\mathrm{n}$ & $\mathrm{n}$ & $\mathrm{n}$ & $\mathrm{n}$ & $\mathrm{n}$ & $\mathrm{n}$ & $\mathrm{n}$ & $\mathrm{n}$ & $\mathrm{n}$ & 0 \\
\hline $\mathrm{N}^{\circ} \operatorname{sim}$ & & 7 & 7 & 10 & 10 & 10 & 10 & 9 & 9 & 6 & 9 & 9 & 8 & Total $=104$ \\
\hline
\end{tabular}

Fonte: Relatórios das missões de observação eleitoral internacionais. Elaboração própria.

Índice de governança eleitoral no dia da eleição $=0,72$ 
Tabela 16 - Matriz de observação para o dia da eleição, México, 1990-2015

\begin{tabular}{|c|c|c|c|c|c|c|c|c|c|c|c|c|c|c|}
\hline Indicadores/Anos & 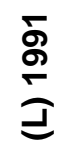 & 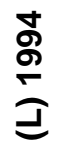 & 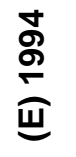 & 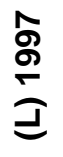 & $\begin{array}{l}\text { O } \\
\stackrel{ }{N} \\
\text { ב }\end{array}$ & $\begin{array}{l}\text { 오 } \\
\text { N } \\
\text { யய }\end{array}$ & 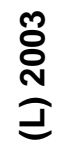 & $\begin{array}{l}0 \\
\stackrel{O}{0} \\
\text { J }\end{array}$ & $\begin{array}{l}\stackrel{\bullet}{8} \\
\stackrel{N}{N} \\
\text { யU }\end{array}$ & $\begin{array}{l}\text { 尺 } \\
\text { 유 } \\
\text { J }\end{array}$ & $\begin{array}{l}\text { N } \\
\text { ల్ } \\
己\end{array}$ & 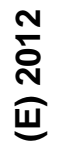 & $\begin{array}{l}\frac{n}{\delta} \\
\stackrel{N}{J}\end{array}$ & Número de sim \\
\hline Ausência de erros nas listas eleitorais & - & $\mathrm{n}$ & $\mathrm{n}$ & $\mathrm{n}$ & $\mathrm{n}$ & $\mathrm{n}$ & $\mathrm{n}$ & $\mathrm{n}$ & $\mathrm{n}$ & $\mathrm{n}$ & $\mathrm{n}$ & $\mathrm{n}$ & $\mathrm{n}$ & 0 \\
\hline Garantia de segurança dos eleitores & - & $\mathrm{n}$ & $\mathrm{n}$ & $\mathrm{s}$ & $\mathrm{s}$ & $\mathrm{s}$ & $\mathrm{s}$ & $\mathrm{n}$ & $\mathrm{n}$ & $\mathrm{s}$ & s & $\mathrm{s}$ & $\mathrm{s}$ & 8 \\
\hline $\begin{array}{l}\text { Presença de material e membros eleitorais na abertura dos } \\
\text { centros }\end{array}$ & - & $\mathrm{n}$ & $\mathrm{n}$ & $\mathrm{n}$ & $\mathrm{n}$ & $\mathrm{n}$ & $\mathrm{n}$ & $\mathrm{n}$ & $\mathrm{n}$ & $\mathrm{s}$ & $\mathrm{s}$ & $\mathrm{s}$ & $\mathrm{s}$ & 4 \\
\hline Pontualidade na abertura dos centros de votação & - & $\mathrm{n}$ & $\mathrm{n}$ & $\mathrm{n}$ & $\mathrm{n}$ & $\mathrm{n}$ & $\mathrm{n}$ & $\mathrm{n}$ & $\mathrm{n}$ & $\mathrm{n}$ & $\mathrm{n}$ & $\mathrm{n}$ & $\mathrm{n}$ & 0 \\
\hline Fácil acesso dos eleitores aos centros de votação & - & $\mathrm{n}$ & $\mathrm{n}$ & $\mathrm{s}$ & $\mathrm{s}$ & $\mathrm{s}$ & $\mathrm{s}$ & $\mathrm{s}$ & $\mathrm{s}$ & $\mathrm{s}$ & $\mathrm{n}$ & $\mathrm{n}$ & $\mathrm{n}$ & 7 \\
\hline Mulheres e grupos minoritários presentes & - & $\mathrm{s}$ & $\mathrm{s}$ & $\mathrm{s}$ & $\mathrm{s}$ & $\mathrm{s}$ & $\mathrm{s}$ & $\mathrm{s}$ & $\mathrm{s}$ & $\mathrm{s}$ & $\mathrm{s}$ & $\mathrm{s}$ & $\mathrm{s}$ & 12 \\
\hline Eleitor informado sobre conteúdo do voto e como votar & - & $\mathrm{n}$ & $\mathrm{n}$ & $\mathrm{s}$ & $\mathrm{s}$ & $\mathrm{s}$ & $\mathrm{n}$ & $\mathrm{s}$ & $\mathrm{s}$ & $\mathrm{n}$ & $\mathrm{n}$ & $\mathrm{n}$ & $\mathrm{n}$ & 5 \\
\hline $\begin{array}{l}\text { Bom preenchimento das atas eleitorais (sem erros e } \\
\text { rasuras) }\end{array}$ & - & $\mathrm{s}$ & $\mathrm{S}$ & $\mathrm{s}$ & $\mathrm{s}$ & $\mathrm{S}$ & $\mathrm{s}$ & $\mathrm{n}$ & $\mathrm{n}$ & $\mathrm{n}$ & $\mathrm{n}$ & $\mathrm{n}$ & $\mathrm{n}$ & 6 \\
\hline Garantia do segredo de voto nas cabines & - & $\mathrm{n}$ & $\mathrm{n}$ & $\mathrm{s}$ & $\mathrm{s}$ & $\mathrm{s}$ & $\mathrm{s}$ & $\mathrm{n}$ & $\mathrm{n}$ & $\mathrm{s}$ & $\mathrm{s}$ & $\mathrm{s}$ & $\mathrm{n}$ & 7 \\
\hline Fácil identificação dos centros de votação pelos eleitores & - & $\mathrm{n}$ & $\mathrm{n}$ & $\mathrm{n}$ & $\mathrm{n}$ & $\mathrm{n}$ & $\mathrm{s}$ & $\mathrm{s}$ & $\mathrm{s}$ & $\mathrm{n}$ & $\mathrm{n}$ & $\mathrm{n}$ & $\mathrm{n}$ & 3 \\
\hline $\begin{array}{l}\text { Ausência de práticas ilegais de voto como compra e } \\
\text { coerção }\end{array}$ & - & $\mathrm{s}$ & s & $\mathrm{n}$ & $\mathrm{n}$ & $\mathrm{n}$ & $\mathrm{n}$ & $\mathrm{n}$ & $\mathrm{n}$ & $\mathrm{s}$ & $\mathrm{n}$ & $\mathrm{n}$ & $\mathrm{n}$ & 3 \\
\hline$N^{\circ} \operatorname{sim}$ & & 3 & 3 & 6 & 6 & 6 & 6 & 4 & 4 & 6 & 4 & 4 & 3 & Total = 55 \\
\hline
\end{tabular}

Fonte: Relatórios das missões de observação eleitoral internacionais. Elaboração própria.

\section{Índice de governança eleitoral no dia da eleição $=0.38$}


Tabela 17 - Matriz de observação pós-eleitorais, México, 1990-2015

\begin{tabular}{|c|c|c|c|c|c|c|c|c|c|c|c|c|c|c|}
\hline Indicadores/Anos & $\begin{array}{l}\bar{g} \\
\frac{\sigma}{\sigma} \\
\Xi\end{array}$ & 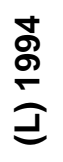 & 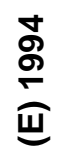 & $\begin{array}{l}\stackrel{ }{g} \\
\stackrel{2}{\Xi}\end{array}$ & $\begin{array}{l}\text { 옹 } \\
\text { 일 } \\
\text { J }\end{array}$ & 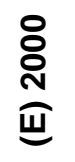 & 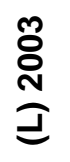 & 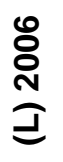 & 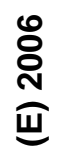 & 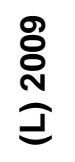 & 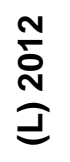 & 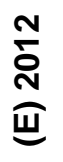 & $\frac{n}{\stackrel{n}{0}}$ & Número de sim \\
\hline $\begin{array}{l}\text { Transporte adequado de material sensível para } \\
\text { contagem }\end{array}$ & - & $\mathrm{s}$ & $\mathrm{s}$ & $\mathrm{s}$ & $\mathrm{s}$ & $\mathrm{s}$ & $\mathrm{s}$ & $\mathrm{s}$ & $\mathrm{s}$ & $\mathrm{n}$ & $\mathrm{s}$ & $\mathrm{s}$ & $\mathrm{s}$ & 11 \\
\hline $\begin{array}{l}\text { Fechamento do centro no horário estipulado pela } \\
\text { lei }\end{array}$ & - & $\mathrm{n}$ & $\mathrm{n}$ & $\mathrm{s}$ & $\mathrm{s}$ & $\mathrm{s}$ & $\mathrm{s}$ & $\mathrm{s}$ & $\mathrm{s}$ & $\mathrm{n}$ & $\mathrm{s}$ & $\mathrm{s}$ & $\mathrm{n}$ & 8 \\
\hline Contagem adequada preliminar e final dos votos & - & $\mathrm{s}$ & $\mathrm{s}$ & $\mathrm{s}$ & $\mathrm{s}$ & $\mathrm{s}$ & s & $\mathrm{n}$ & $\mathrm{n}$ & $\mathrm{n}$ & $\mathrm{s}$ & $\mathrm{s}$ & $\mathrm{s}$ & 9 \\
\hline Rápida divulgação de resultados & - & $\mathrm{s}$ & $\mathrm{s}$ & $\mathrm{s}$ & $\mathrm{s}$ & $\mathrm{s}$ & $\mathrm{s}$ & $\mathrm{n}$ & $\mathrm{n}$ & $\mathrm{s}$ & $\mathrm{s}$ & $\mathrm{s}$ & $\mathrm{s}$ & 10 \\
\hline $\begin{array}{l}\text { Pouca divergência entre resultados preliminar e } \\
\text { final }\end{array}$ & - & $s$ & $\mathrm{~s}$ & $\mathrm{~s}$ & $\mathrm{~s}$ & $\mathrm{~s}$ & $\mathrm{~s}$ & $\mathrm{n}$ & $\mathrm{n}$ & $s$ & $\mathrm{~s}$ & $\mathrm{~s}$ & $\mathrm{~s}$ & 10 \\
\hline Existência de instância para análise de denúncias & - & $\mathrm{n}$ & $\mathrm{n}$ & $\mathrm{s}$ & $\mathrm{s}$ & $\mathrm{s}$ & $\mathrm{s}$ & $\mathrm{s}$ & $\mathrm{s}$ & $\mathrm{s}$ & $\mathrm{s}$ & $\mathrm{s}$ & $\mathrm{s}$ & 10 \\
\hline $\begin{array}{l}\text { Padronização de procedimentos entre centros de } \\
\text { votacão }\end{array}$ & - & $\mathrm{n}$ & $\mathrm{n}$ & $\mathrm{n}$ & $\mathrm{n}$ & $\mathrm{n}$ & $\mathrm{n}$ & $\mathrm{s}$ & $\mathrm{s}$ & $\mathrm{n}$ & $\mathrm{n}$ & $\mathrm{n}$ & $\mathrm{s}$ & 3 \\
\hline $\begin{array}{l}\text { Aceitação dos resultados finais por candidatos e } \\
\text { oposição }\end{array}$ & - & $\mathrm{n}$ & $\mathrm{n}$ & $\mathrm{s}$ & $\mathrm{s}$ & $\mathrm{s}$ & $\mathrm{s}$ & $\mathrm{n}$ & $\mathrm{n}$ & $\mathrm{s}$ & $\mathrm{n}$ & $\mathrm{n}$ & $\mathrm{s}$ & 6 \\
\hline Instrumentos confiáveis de contagem e tabulação & - & $\mathrm{s}$ & $\mathrm{s}$ & $\mathrm{s}$ & $\mathrm{s}$ & $\mathrm{s}$ & $\mathrm{s}$ & $\mathrm{n}$ & $\mathrm{n}$ & $\mathrm{s}$ & $\mathrm{s}$ & $\mathrm{s}$ & $\mathrm{s}$ & 10 \\
\hline $\begin{array}{l}\text { Ausência de muitos votos em um candidato } \\
\text { apenas }\end{array}$ & - & $\mathrm{n}$ & $\mathrm{n}$ & $\mathrm{s}$ & $\mathrm{s}$ & $\mathrm{s}$ & $\mathrm{s}$ & $\mathrm{s}$ & $\mathrm{s}$ & $\mathrm{s}$ & $\mathrm{s}$ & $\mathrm{s}$ & $\mathrm{s}$ & 10 \\
\hline Ausência de violência pós-eleitoral & - & $\mathrm{s}$ & $\mathrm{s}$ & $\mathrm{s}$ & $\mathrm{s}$ & $\mathrm{s}$ & $\mathrm{s}$ & $\mathrm{s}$ & $\mathrm{s}$ & $\mathrm{s}$ & $\mathrm{s}$ & $\mathrm{s}$ & $\mathrm{s}$ & 12 \\
\hline Baixo índice de abstenções (presença e voto) & - & $\mathrm{s}$ & $\mathrm{s}$ & $\mathrm{s}$ & $\mathrm{s}$ & $\mathrm{s}$ & $\mathrm{n}$ & $\mathrm{s}$ & $\mathrm{s}$ & $\mathrm{s}$ & $\mathrm{n}$ & $\mathrm{n}$ & $\mathrm{s}$ & 9 \\
\hline$N^{\circ} \operatorname{sim}$ & & 7 & 7 & 11 & 11 & 11 & 10 & 7 & 7 & 8 & 9 & 9 & 11 & Total $=108$ \\
\hline
\end{tabular}

Fonte: Relatórios das missões de observação eleitoral internacionais. Elaboração própria.

Índice de governança eleitoral no dia da eleição $=0.7$ 
Embora a observação tenha se estabelecido no país já nas primeiras eleições dos anos 1990, muitos dos seus esforços se voltaram para a pressão sobre os governos, que deveriam do ponto de vista das missões, implementar procedimentos mais rigorosos de organização e contagem de votos. Em outras palavras, o resultado obtido poderia ser explicado pelo próprio caráter da observação internacional no México, que se voltou para aspectos mais técnicos do processo eleitoral, a fim de tornar as eleições mais próximas dos padrões normativos internacionais democráticos.

Pastor (1998) diz que embora a falácia do eleitoralismo (Schmitter e Karl, 1991) ainda seja uma crítica pertinente nos dias atuais, ele defende que a maioria dos acadêmicos da área de governança, concorda que as eleições são uma parte fundamental da democracia. De modo que a observação internacional assumiu papel central, sobretudo após o fim da Guerra Fria, "quando a norma das eleições livres e justas como uma base governativa legítima se tornou praticamente universal" (Pastor, 1998, p. 154). Para além do papel de portavozes dessa nova norma, os observadores internacionais podem assumir diferentes funções.

Para o autor ainda, as missões são diversificadas, possuindo diferentes funções, potencialidades e falhas. Entre as funções que uma missão pode assumir no desempenho de suas atividades, está o da verificação, observação, monitoramento e mediação.

Kelley (2012) argumenta que muitas vezes os observadores realizam o papel de verificação das eleições, quando os governos são incapazes de conduzir uma eleição sem fraudes, de forma autônoma, porém necessitam de aprovação internacional, para o recebimento de recursos econômicos e outros benefícios. Em outras palavras, os monitores internacionais podem aumentar os benefícios de realizar eleições limpas exercendo seu papel de verificação. Sem monitores, uma eleição limpa pode não ser recompensada se os políticos não puderem demonstrar que a eleição de contou com uma boa governança eleitoral. No entanto, se os monitores verificarem as eleições, considerando-as limpas, elas se tornam mais valiosas e, também, mais atraentes.

Esse foi o caso das eleições realizadas no México. Em um país cuja a incerteza processual (Schedler, 2002a e Elklit e Reynolds, 2005) não estava garantida, devido à dominação que o PRI exercia sobre a política, de uma forma 
geral, dificultando a competição política e, aumentando a previsibilidade sobre os resultados das disputas eleitorais.

Dessa forma, há grande preocupação do país com a fase pós-eleitoral, pois é nesse momento que são agrupados os indicadores para contagem, tabulação e publicação de resultados, que, mais tarde, serão divulgados para o público doméstico e internacional e é importante demonstrar que a eleição teve resultados credíveis. Assim como, é importante que os observadores internacionais atestem a melhoria da competição política na fase pré-eleitoral.

Por outro lado, as reformas eleitorais, realizadas no país, em atendimento às recomendações das missões internacionais eleitorais, realizadas no país, permitiram melhor organização dos pleitos, criação de um organismo eleitoral independente e diminuição de focos de violência. Dessa forma, o índice de governança eleitoral da fase pré-eleitoral, 0.72 , chega perto da categoria mais alta. O resultado, no entanto, do dia da votação, atinge nível haitiano: 0.38 . Nesta fase, concentram-se, então, no México, as más práticas.

É importante salientarmos que o México já possuía eleições, ainda que manipuladas, durante o período de sistema de partido único. No entanto, o México faz parte de um grupo de países cujos governos imitaram, de forma mnemônica, comportamentos considerados desejáveis, do ponto de vista da promoção da democracia, para que suas eleições fossem reconhecidas no plano internacional, sem muitas vezes, alterar sua cultura política (Hyde, 2011).

O México tem realizado reformas consecutivas em seu sistema eleitoral, desde meados de 1993. Para Magaloni (2006), cada uma das reformas introduziu inovações no sistema eleitoral mexicano.

As eleições de 1994 ocorreram após a remoção de quase todas as barreiras à liberalização econômica, e entrada do país no Nafta, tornando o país mais integrado aos mercados internacionais. No plano doméstico, a situação econômica não ia bem. O PRI teve dificuldades em manter a estabilidade das contas públicas, porém para a maioria dos eleitores, era o partido que teria melhores condições de enfrentar o futuro incerto da economia nacional (idem). Somado a isso há o fato que de irromperam as ações dos grupos armados zapatistas, culminando no assassinato do candidato à presidência, do PRI, Luis Donaldo Colosio. 
Ambas as situações contribuíram para a reforma do IFE de 1993, que garantiu a transparência e integridade necessárias ao processo eleitoral, evitando críticas de fraude por parte da oposição. Entre as inovações da reforma, estava o estabelecimento dos Conselheiros Cidadãos (Consejeros Ciudadanos), grupo de seis cidadãos eleitos para coordenar as atividades do IFE, sendo cada um deles indicado pelos maiores partidos mexicanos: PRI, PAN e PRD.

Eisenstadt (2003) reforça a tese de que esses episódios contribuíram para a maior abertura também no campo eleitoral, porém, para o autor, esses acontecimentos sozinhos não poderiam determinar o rumo das mudanças. $\mathrm{Ou}$ seja, para ele, o estabelecimento de um maior ativismo político na arena eleitoral é que foi, de fato, fundamental para as reformas observadas nos últimos anos.

O boom de organizações sociais aconteceu no início dos anos $1990 \mathrm{em}$ áreas novas como meio ambiente e direitos humanos. Lean (2012) argumenta que muitas demandas sociais, a exemplo da democracia, que foi ignorada por tanto tempo, se tornou uma causa comum para muitas delas, particularmente, "as organizações voltadas à defesa dos direitos humanos, que passaram a se questionar sobre a possibilidade de aplicar métodos de monitoramento de direitos humanos ao monitoramento de violações de direitos políticos" (p. 65). $E$, assim, muitas organizações domésticas passaram a monitorar os processos eleitorais no país, identificando, por exemplo, irregularidades nas eleições de 1991, quando observaram centros eleitorais nos quais o PRI havia recebido $100 \%$ dos votos (idem).

Essa foi uma das principais deficiências identificadas pelos observadores internacionais. O relatório do Centro Carter, de 1994, apontou, inclusive uma baixa confiança no processo eleitoral por parte dos eleitores, em virtude de práticas ilegais, como a alta porcentagem de votos em um só candidato, em vários centros eleitorais (CC, 1994). Os observadores citam, também, a grande disparidade entre recursos financeiros disponíveis para cada um dos partidos, tendo o PRI o benefício de receber mais que qualquer outro partido, sem, necessariamente comunicar a sua fonte de origem (idem).

Segundo a Idea (2014), as eleições realizadas em muitos países da América Latina têm sido qualificadas como democráticas, porque satisfazem os requisitos básicos de eleições livres, justas, limpas, competitivas e 
transparentes. Sem dúvida, sua validade e legitimidade ainda são frágeis, perante questões como a garantia da participação popular, por exemplo.

Em 1994, a preocupação em melhorar os índices de confiança foi apontada pelo Ifes (1994), que via na maior independência do IFE o caminho a ser seguido. No entanto, a missão assinalou que a troca de liderança dos Conselheiros Cidadãos dois meses apenas antes do dia da votação não havia sido medida suficiente para garantir a confiança no processo, sendo necessário que o organismo fosse realmente independente, para aplicação de penalidades, caso fraudes tivessem ocorrido.

Apesar do baixo nível de confiança, o processo eleitoral em 1994 teve uma alta taxa de participação popular, acima dos 50\%. Essa não foi, no entanto, uma tendência que se manteve, visto que muitos relatórios apontaram o absenteísmo em vários dos processos eleitorais realizados no período de estudo. Porém, Klesner (2001) afirma que os padrões de participação eleitoral têm se modificado bastante no México, saindo de um padrão com muitas abstenções, para o de eleitores mais conscientes e engajados. Para o autor, o absenteísmo se manteve alto nos últimos anos em função da crença do eleitorado de que seu voto não seria contabilizado de forma honesta, porém, com as reformas realizadas nos últimos anos, sobretudo em 1996, isso mudou.

A reforma de 1996 trouxe maior competição para o campo eleitoral, verificada já nas eleições federais de 1997, que, para muitos, marcou o fim da longa transição da democracia. Hoyos (2003, p. 114) complementa que "os comícios de 2000 não só confirmaram a existência de eleições democráticas no país, como a alternância na presidência da república".

Assim,

"Quando os mexicanos foram às urnas nos anos 2000 , eles cruzaram
uma ponte final para o sistema político competitivo. Pela primeira vez,
havia incerteza em relação à qual partido assumiria a presidência, e
essa incerteza confirmou o fato de que livres escolhas haviam sido
estabelecidas no país, independentemente do resultado final" (CC,
2000, p. 12).

Muitos dos relatórios indicaram ainda o amadurecimento da competição eleitoral como algo positivo em vista das tendências existentes na região, à época. O Centro Carter, declarou que:

“... a bem-sucedida transição do México para a democracia tornou-se ainda mais significativa em função de eventos recentes como as fracassadas eleições no Peru e o golpe no Equador, que sugerem uma 
profunda perturbação da democracia em alguns dos países latinoamericanos (CC, 2000, p. 5).

O IRI (2000) atribui esse sucesso também às reformas realizadas em 1996, que reforçaram o maior nível de independência e autonomia do IFE, eliminando completamente os representantes do Poder Executivo, da liderança do corpo eleitoral. Na época, foi discutida ainda a profissionalização dos conselheiros cidadãos, que passaram a ser reconhecidos como conselheiros eleitorais.

Apesar dos avanços em termos de reformas eleitorais, que tornaram mais igualitários os limites financeiros disponíveis a cada partido e introduziram a competição eleitoral, é no dia da eleição, conforme indicado, que estão concentrados as más práticas mais difíceis de serem modificadas. Nas eleições de 2000 ainda, os observadores testemunharam o transporte de eleitores até os centros de votação e receberam denúncias de compra de votos, além de outros tipos de coação (IRI, 2000; PE, 2000; CC, 2000).

Dessa forma, o que pudemos perceber com os primeiros resultados de observação é que embora o México tenha melhor pontuação em aspectos procedimentais, relativos à organização e divulgação de resultados de seus processos eleitorais, ainda há aspectos a serem melhorados com sua condução, sobretudo, no dia da votação.

\subsection{Visitantes estrangeiros e o impacto das recomendações no sistema eleitoral mexicano}

É fato que a observação internacional de eleições é uma evidência que mostra como os atores externos podem influenciar o comportamento de governos. A forma como os governos irão responder a essa influência varia conforme uma combinação de incentivos (Kelley, 2012).

O México respondeu realizando reformas que impactaram, principalmente, nos períodos pré e pós-eleitorais, sendo que tentativas de manipulação de votos, acosso de eleitores e outras práticas maliciosas, ainda continuam a existir, no dia da eleição.

No entanto, é possível identificar três papeis principais para a observação internacional nas eleições mexicanas. Ela facilitou a criação de redes de 
observação doméstica dos processos eleitorais (Lean, 2012), desempenhou a tarefa de verificação (Pastor, 1998) e indicou os pontos mais sensíveis dos pleitos, que deveriam ser melhorados, através de suas recomendações (Kelley, 2012).

De uma forma geral, obtivemos os seguintes índices para as recomendações das missões de observação eleitoral internacionais, no México, a partir do quadro e tabelas abaixo:

Quadro 9 - Índice de Implementação das recomendações das MOEls, México

\begin{tabular}{ccc}
\hline País & Fase & Índice \\
\hline \multirow{3}{*}{ México } & Pré-eleitoral & $0.76 \rightarrow$ Médio \\
& Dia da votação & $0.45 \rightarrow$ Médio \\
& Pós-eleitoral & $0.72 \rightarrow$ Médio \\
\hline
\end{tabular}


Tabela 18 - Matriz das recomendações para o período pré-eleitoral, México, 1990-2015

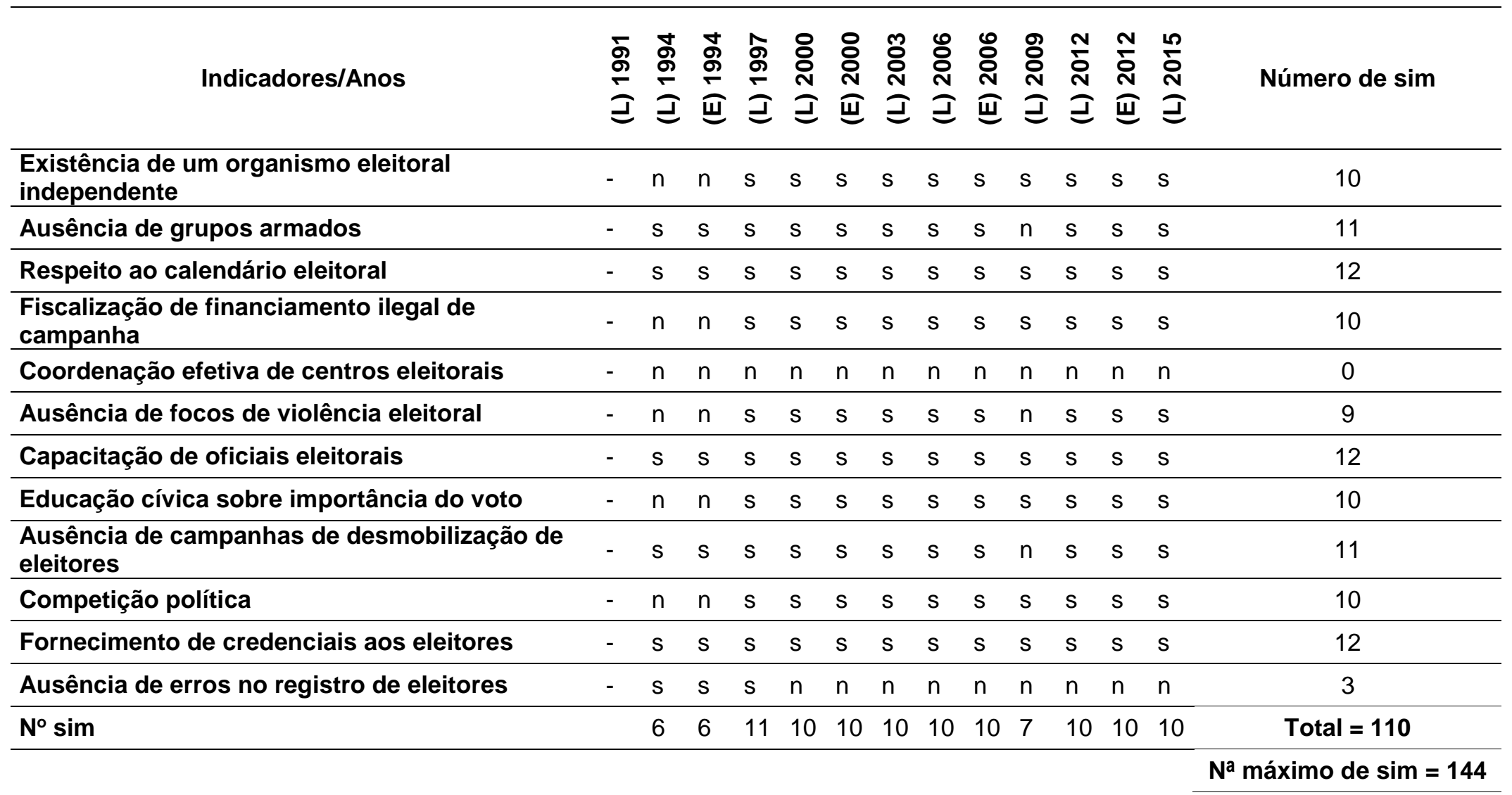

Fonte: Relatórios das missões de observação eleitoral internacionais. Elaboração própria.

\section{Índice de implementação das recomendações $=0.76$}


Tabela 19 - Matriz das recomendações para o dia da eleição, México, 1990-2015

\begin{tabular}{|c|c|c|c|c|c|c|c|c|c|c|c|c|c|c|}
\hline Indicadores/Anos & $\begin{array}{l}\frac{5}{\circ} \\
\stackrel{9}{\beth}\end{array}$ & 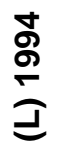 & 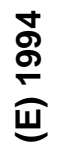 & 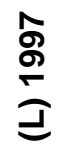 & $\begin{array}{l}\text { 옹 } \\
\text { 己 }\end{array}$ & 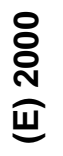 & 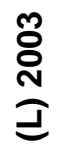 & 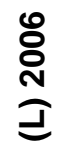 & 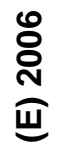 & $\begin{array}{l}\text { 옹 } \\
\text { ㄱ. } \\
\text { త }\end{array}$ & $\begin{array}{l}\text { N } \\
\text { O } \\
\text { J }\end{array}$ & $\begin{array}{l}\text { N } \\
\text { ণ } \\
\text { யூ }\end{array}$ & $\begin{array}{l}\text { ㅇ } \\
\text { 을 }\end{array}$ & Número de sim \\
\hline Ausência de erros nas listas eleitorais & - & $\mathrm{n}$ & $\mathrm{n}$ & $\mathrm{n}$ & $\mathrm{n}$ & $\mathrm{n}$ & $\mathrm{n}$ & $\mathrm{n}$ & $\mathrm{n}$ & $\mathrm{n}$ & $\mathrm{n}$ & $\mathrm{n}$ & $\mathrm{n}$ & 0 \\
\hline Garantia de segurança dos eleitores & - & $\mathrm{n}$ & $\mathrm{n}$ & $\mathrm{s}$ & $\mathrm{s}$ & $\mathrm{s}$ & $\mathrm{s}$ & $\mathrm{s}$ & $\mathrm{s}$ & $\mathrm{s}$ & $\mathrm{s}$ & $\mathrm{s}$ & $\mathrm{s}$ & 10 \\
\hline $\begin{array}{l}\text { Presença de material e membros eleitorais na abertura dos } \\
\text { centros }\end{array}$ & - & $\mathrm{n}$ & $\mathrm{n}$ & $\mathrm{n}$ & $\mathrm{n}$ & $\mathrm{n}$ & $\mathrm{n}$ & $\mathrm{n}$ & $\mathrm{n}$ & $\mathrm{s}$ & $\mathrm{s}$ & $\mathrm{s}$ & $\mathrm{s}$ & 4 \\
\hline Pontualidade na abertura dos centros de votação & - & $\mathrm{n}$ & $\mathrm{n}$ & $\mathrm{n}$ & $\mathrm{n}$ & $\mathrm{n}$ & $\mathrm{n}$ & $\mathrm{n}$ & $\mathrm{n}$ & $\mathrm{n}$ & $\mathrm{n}$ & $\mathrm{n}$ & $\mathrm{n}$ & 0 \\
\hline Fácil acesso dos eleitores aos centros de votação & - & $\mathrm{s}$ & $\mathrm{s}$ & $\mathrm{s}$ & $\mathrm{s}$ & $\mathrm{s}$ & $\mathrm{s}$ & $\mathrm{s}$ & $\mathrm{s}$ & $\mathrm{n}$ & $\mathrm{n}$ & $\mathrm{n}$ & $\mathrm{n}$ & 8 \\
\hline Mulheres e grupos minoritários presentes & - & $\mathrm{s}$ & $\mathrm{s}$ & $\mathrm{s}$ & $\mathrm{s}$ & $\mathrm{s}$ & $\mathrm{s}$ & $\mathrm{s}$ & $\mathrm{s}$ & $\mathrm{s}$ & $\mathrm{s}$ & $\mathrm{s}$ & $\mathrm{s}$ & 12 \\
\hline Eleitor informado sobre conteúdo do voto e como votar & - & $\mathrm{n}$ & $\mathrm{n}$ & $\mathrm{s}$ & $\mathrm{s}$ & $\mathrm{s}$ & $\mathrm{n}$ & $\mathrm{s}$ & $\mathrm{s}$ & $\mathrm{s}$ & $\mathrm{n}$ & $\mathrm{n}$ & $\mathrm{s}$ & 7 \\
\hline $\begin{array}{l}\text { Bom preenchimento das atas eleitorais (sem erros e } \\
\text { rasuras) }\end{array}$ & - & $\mathrm{s}$ & $\mathrm{s}$ & $\mathrm{s}$ & $\mathrm{s}$ & $\mathrm{s}$ & $\mathrm{s}$ & $\mathrm{s}$ & $\mathrm{s}$ & $\mathrm{n}$ & $\mathrm{n}$ & $\mathrm{n}$ & $\mathrm{n}$ & 8 \\
\hline Garantia do segredo de voto nas cabines & - & $\mathrm{n}$ & $\mathrm{n}$ & s & $\mathrm{s}$ & $\mathrm{s}$ & $\mathrm{s}$ & $\mathrm{n}$ & $\mathrm{n}$ & $\mathrm{s}$ & $\mathrm{s}$ & $\mathrm{s}$ & $\mathrm{n}$ & 7 \\
\hline Fácil identificação dos centros de votação pelos eleitores & - & $\mathrm{n}$ & $\mathrm{n}$ & $\mathrm{s}$ & $\mathrm{n}$ & $\mathrm{n}$ & $\mathrm{s}$ & $\mathrm{s}$ & $\mathrm{s}$ & $\mathrm{n}$ & $\mathrm{n}$ & $\mathrm{n}$ & $\mathrm{n}$ & 4 \\
\hline $\begin{array}{l}\text { Ausência de práticas ilegais de voto como compra e } \\
\text { coerção }\end{array}$ & - & $\mathrm{s}$ & $\mathrm{s}$ & $\mathrm{n}$ & $\mathrm{n}$ & $\mathrm{n}$ & $\mathrm{n}$ & $\mathrm{n}$ & $\mathrm{n}$ & $\mathrm{s}$ & $\mathrm{n}$ & $\mathrm{n}$ & $\mathrm{n}$ & 3 \\
\hline \multirow[t]{2}{*}{$N^{\circ} \operatorname{sim}$} & & 4 & 4 & 7 & 6 & 6 & 6 & 6 & 6 & 7 & 5 & 5 & 4 & Total = 66 \\
\hline & & & & & & & & & & & & & \multicolumn{2}{|r|}{ Na máximo de $\operatorname{sim}=144$} \\
\hline
\end{tabular}

Fonte: Relatórios das missões de observação eleitoral internacionais. Elaboração própria.

Índice de implementação das recomendações $=0.45$ 
Tabela 20 - Matriz das recomendações para o período pós-eleitoral, 1990-2015

\begin{tabular}{|c|c|c|c|c|c|c|c|c|c|c|c|c|c|c|}
\hline Indicadores/Anos & $\begin{array}{l}\frac{\sigma}{\sigma} \\
\stackrel{\Xi}{\beth}\end{array}$ & $\begin{array}{l}\text { ஓ } \\
\stackrel{\sigma}{\sigma} \\
\text { 己 }\end{array}$ & 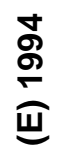 & $\begin{array}{l}\hat{\sigma} \\
\stackrel{\sigma}{\sigma} \\
\Xi\end{array}$ & 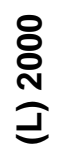 & $\begin{array}{l}\text { 옹 } \\
\text { N } \\
\text { யூ }\end{array}$ & 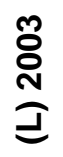 & $\begin{array}{l}\stackrel{8}{8} \\
\stackrel{\text { N }}{\beth}\end{array}$ & $\begin{array}{l}\stackrel{0}{8} \\
\stackrel{\text { N }}{\text { யூ }}\end{array}$ & $\begin{array}{l}\text { 응 } \\
\text { 을 } \\
\text { 己. }\end{array}$ & 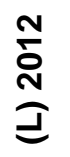 & 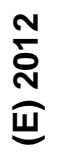 & $\begin{array}{l}\frac{n}{0} \\
\stackrel{\text { N }}{\beth}\end{array}$ & Número de sim \\
\hline $\begin{array}{l}\text { Transporte adequado de material sensível para } \\
\text { contagem }\end{array}$ & - & $\mathrm{s}$ & s & $\mathrm{s}$ & s & s & s & s & s & $\mathrm{s}$ & s & s & $\mathrm{s}$ & 12 \\
\hline $\begin{array}{l}\text { Fechamento do centro no horário estipulado pela } \\
\text { lei }\end{array}$ & - & $\mathrm{s}$ & s & $\mathrm{s}$ & $n$ & $\mathrm{n}$ & s & s & s & $\mathrm{s}$ & s & S & s & 10 \\
\hline Contagem adequada preliminar e final dos votos & - & $\mathrm{s}$ & s & $\mathrm{s}$ & s & $\mathrm{s}$ & s & s & s & $\mathrm{n}$ & s & s & s & 11 \\
\hline Rápida divulgação de resultados & - & $\mathrm{s}$ & s & $\mathrm{s}$ & s & $\mathrm{s}$ & s & $\mathrm{n}$ & $\mathrm{n}$ & s & s & s & s & 10 \\
\hline $\begin{array}{l}\text { Pouca divergência entre resultados preliminar e } \\
\text { final }\end{array}$ & - & $\mathrm{s}$ & $\mathrm{s}$ & $\mathrm{s}$ & s & $\mathrm{s}$ & s & $\mathrm{n}$ & $\mathrm{n}$ & $\mathrm{s}$ & $\mathrm{n}$ & $\mathrm{n}$ & s & 8 \\
\hline Existência de instância para análise de denúncias & - & $\mathrm{s}$ & s & $\mathrm{s}$ & s & s & $\mathrm{s}$ & s & $\mathrm{s}$ & $\mathrm{s}$ & $\mathrm{s}$ & s & s & 12 \\
\hline $\begin{array}{l}\text { Padronização de procedimentos entre centros de } \\
\text { votação }\end{array}$ & - & $\mathrm{n}$ & $\mathrm{n}$ & $\mathrm{n}$ & $\mathrm{n}$ & $\mathrm{n}$ & $\mathrm{n}$ & s & s & $\mathrm{n}$ & $\mathrm{n}$ & $n$ & s & 3 \\
\hline $\begin{array}{l}\text { Aceitação dos resultados finais por candidatos e } \\
\text { oposição }\end{array}$ & - & $\mathrm{n}$ & $\mathrm{n}$ & $\mathrm{s}$ & s & $\mathrm{s}$ & s & $\mathrm{n}$ & $\mathrm{n}$ & $\mathrm{s}$ & $\mathrm{n}$ & $\mathrm{n}$ & s & 6 \\
\hline Instrumentos confiáveis de contagem e tabulação & - & $\mathrm{s}$ & s & s & s & $\mathrm{s}$ & s & $\mathrm{s}$ & s & $\mathrm{s}$ & s & s & s & 12 \\
\hline $\begin{array}{l}\text { Ausência de muitos votos em um candidato } \\
\text { apenas }\end{array}$ & - & $\mathrm{s}$ & s & $\mathrm{n}$ & $\mathrm{n}$ & $\mathrm{n}$ & $\mathrm{n}$ & $\mathrm{n}$ & $\mathrm{n}$ & $\mathrm{n}$ & $\mathrm{n}$ & $n$ & $\mathrm{n}$ & 2 \\
\hline Ausência de violência pós-eleitoral & - & $\mathrm{s}$ & s & $\mathrm{s}$ & s & $\mathrm{s}$ & s & s & s & $\mathrm{s}$ & s & s & $\mathrm{s}$ & 12 \\
\hline Baixo índice de abstenções (presença e voto) & - & $\mathrm{n}$ & $\mathrm{n}$ & $\mathrm{s}$ & s & $\mathrm{s}$ & $\mathrm{n}$ & $\mathrm{n}$ & $\mathrm{n}$ & $\mathrm{s}$ & s & s & s & 7 \\
\hline$N^{\circ} \operatorname{sim}$ & & 9 & 9 & 10 & 9 & 9 & 9 & 7 & 7 & 9 & 8 & 8 & 11 & Total $=105$ \\
\hline
\end{tabular}

Fonte: Relatórios das missões de observação eleitoral internacionais. Elaboração própria.

Índice de implementação das recomendações $=0.7$ 
Brevemente, se faz importante mencionar algumas das recomendações que foram implementadas, após sugestões das missões internacionais de monitoramento eleitoral e, algumas, que mesmo tendo sido recomendadas, não se modificaram. Mesmo as missões informais de organizações internacionais de monitoramento de eleições, enviadas em processos eleitorais anteriores à sua legalização, como uma prática aceita no país, geraram recomendações que foram adotadas para as eleições de 1994. Entre as recomendações informais adotadas pelo governo de Salinas, estavam: os acordos para a realização de auditorias de listas de registro de eleitores; o aumento da autonomia do IFE, com relação à influência dos partidos políticos; o acesso dos observadores domésticos aos centros eleitorais e, a decisão de creditar visitantes internacionais para observar as eleições (idem).

Em 1994, o Ifes levantou questionamentos sobre problemas relacionados à falta de independência do organismo eleitoral, recomendando seu desligamento do Ministério do Interior e, o aumento do envolvimento de cidadãos no seu quadro de funcionários (Ifes, 1994). A resposta do IFE veio na criação dos Conselheiros Cidadãos, maior autonomia dos organismos eleitoral, que se tornara um pouco menos partidarizado e estabelecimento do TEPJF, após as reformas de 1996 (Eisenstadt, 2003).

O Centro Carter (1994) também fez apontamentos nessa eleição, que, depois, se tornaram práticas. Os observadores internacionais colocaram as finanças da campanha e do partido na agenda política, de modo que, foram abertos mais espaços de divulgação dos concorrentes, a exemplo da realização de debates televisivos entre os principais candidatos à presidência, contribuindo para a melhoria da competição política, mais especificamente.

Nas eleições de 1997, essa ampliação da competição política se configurou na perda da maioria legislativa do PRI. Se de um lado, os observadores se davam por satisfeitos com essa mudança no tom da política mexicana, por outro enfatizavam perigos à boa governança eleitoral, como a manutenção da má prática de compra de votos e fraude, em áreas rurais (CC, 1997).

Porém, há também recomendações que não foram implementadas, que foram sumarizadas no Quadro 10, junto àquelas implementadas: 


\section{Quadro 10 - Implementação das recomendações das MOEls, México}

\begin{tabular}{|c|c|c|c|}
\hline Período & & Observações & $\begin{array}{l}\text { Percentual } \\
\text { de } \\
\text { implement } \\
\text { ação (\%) }\end{array}$ \\
\hline \multirow{12}{*}{$\begin{array}{l}\text { Pré- } \\
\text { eleitoral }\end{array}$} & \multirow{2}{*}{$\begin{array}{c}\text { Não } \\
\text { implementadas } \\
{[1]}\end{array}$} & Coordenação efetiva de centros eleitorais & $0 \%$ \\
\hline & & Ausência de erros no registro de eleitores & $25 \%$ \\
\hline & $\begin{array}{c}\text { Parcialmente } \\
\text { implementadas } \\
\text { [2] }\end{array}$ & Ausência de focos de violência eleitoral & $75 \%$ \\
\hline & \multirow{9}{*}{$\begin{array}{l}\text { Implementadas } \\
\text { [3] }\end{array}$} & Existência de um organismo eleitoral independente & $83 \%$ \\
\hline & & Fiscalização de financiamento ilegal de campanha & $83 \%$ \\
\hline & & Educação cívica sobre importância do voto & $83 \%$ \\
\hline & & Competição política & $83 \%$ \\
\hline & & Ausência de grupos armados & $91 \%$ \\
\hline & & Respeito ao calendário eleitoral & $100 \%$ \\
\hline & & $\begin{array}{l}\text { Ausência de campanhas de desmobilização de } \\
\text { eleitores }\end{array}$ & $100 \%$ \\
\hline & & Capacitação de oficiais eleitorais & $100 \%$ \\
\hline & & Fornecimento de credenciais aos eleitores & $100 \%$ \\
\hline \multirow{12}{*}{$\begin{array}{l}\text { Dia da } \\
\text { votação }\end{array}$} & \multirow{6}{*}{$\begin{array}{l}\text { Não } \\
\text { implementadas }\end{array}$} & Ausência de erros nas listas eleitorais & $0 \%$ \\
\hline & & Pontualidade na abertura dos centros de votação & $0 \%$ \\
\hline & & $\begin{array}{l}\text { Ausência de focos de violência e intimidação de } \\
\text { eleitores }\end{array}$ & $25 \%$ \\
\hline & & $\begin{array}{l}\text { Ausência de práticas ilegais de voto como compra } \\
\text { e coerção }\end{array}$ & $25 \%$ \\
\hline & & $\begin{array}{l}\text { Presença de material eleitoral e membros de mesa } \\
\text { na abertura dos centros }\end{array}$ & $33 \%$ \\
\hline & & $\begin{array}{l}\text { Fácil identificação dos centros de votação pelos } \\
\text { eleitores }\end{array}$ & $33 \%$ \\
\hline & \multirow{4}{*}{$\begin{array}{l}\text { Parcialmente } \\
\text { implementadas }\end{array}$} & $\begin{array}{l}\text { Eleitor informado sobre conteúdo do voto e como } \\
\text { votar }\end{array}$ & $58 \%$ \\
\hline & & Garantia do segredo de voto nas cabines & $58 \%$ \\
\hline & & Fácil acesso dos eleitores aos centros de votação & $66 \%$ \\
\hline & & $\begin{array}{l}\text { Bom preenchimento das atas eleitorais (sem erros } \\
\text { e rasuras) }\end{array}$ & $66 \%$ \\
\hline & \multirow{2}{*}{ Implementadas } & Garantia de segurança dos eleitores & \multirow{2}{*}{$\begin{array}{c}83 \% \\
100 \%\end{array}$} \\
\hline & & Mulheres e grupos minoritários presentes & \\
\hline \multirow{11}{*}{$\begin{array}{l}\text { Pós- } \\
\text { eleitoral }\end{array}$} & \multirow[b]{2}{*}{$\begin{array}{l}\text { Não } \\
\text { implementadas }\end{array}$} & Ausência de muitos votos em um candidato apenas & $16 \%$ \\
\hline & & $\begin{array}{l}\text { Padronização de procedimentos entre centro de } \\
\text { votação }\end{array}$ & $25 \%$ \\
\hline & \multirow{3}{*}{$\begin{array}{l}\text { Parcialmente } \\
\text { implementadas }\end{array}$} & $\begin{array}{l}\text { Aceitação dos resultados finais por candidatos e } \\
\text { oposição }\end{array}$ & $50 \%$ \\
\hline & & Baixo índice de abstenções (presença e voto) & $58 \%$ \\
\hline & & $\begin{array}{l}\text { Pouca divergência entre resultados preliminar e } \\
\text { final }\end{array}$ & $66 \%$ \\
\hline & \multirow{6}{*}{ Implementadas } & $\begin{array}{l}\text { Fechamento do centro no horário estipulado pela } \\
\text { lei }\end{array}$ & $83 \%$ \\
\hline & & Rápida divulgação de resultados & $83 \%$ \\
\hline & & Contagem adequada preliminar e final dos votos & $91 \%$ \\
\hline & & Existência de instância para análise de denúncias & $100 \%$ \\
\hline & & Instrumentos confiáveis de contagem e tabulação & $100 \%$ \\
\hline & & Ausência de violência pós-eleitoral & $100 \%$ \\
\hline
\end{tabular}


[1]As recomendações que não foram implementadas variam de $0 \%$ a $39 \%$.

[2]As recomendações que foram parcialmente implementadas variam de $40 \%$ a $79 \%$

[3]As recomendações que foram implementadas variam de $80 \%$ a $100 \%$

Fonte: elaboração própria com base nos resultados das tabelas de matrizes das recomendações para o período pré-eleitoral, durante a eleição e pós-eleitoral.

Nos períodos pré e pós-eleitorais, são poucas as más práticas observadas, tendo o IFE realizado uma série de mudanças apontadas pelos observadores, como fundamentais para a boa governança eleitoral.

Mas se há persistência de práticas que minam a legitimidade dos processos eleitorais mexicanos, as missões impactaram de forma positiva esses indicadores. Esse impacto, entretanto, pode ser considerado médio pela persistência de determinadas práticas, destarte as recomendações feitas. Entre as más práticas persistentes, podem ser citadas a continuidade nos erros relacionados ao registro de eleitores no período pré-eleitoral, que frequentemente têm sido apontados pelos observadores como contendo eleitores duplicados ou fantasmas; as incongruências nas listas eleitorais, no dia da eleição, decorrentes dos erros relacionados aos registros iniciais e; a tendência à concentração de votos em um só candidato no pós-eleitoral, devido à recente competição política, que ganhou terreno nas eleições legislativas de 1997 e que se estabeleceu, de fato, nas eleições presidenciais, em 2000.

Entre as ações de boa governança eleitoral, merecem destaque aquelas realizadas depois do dia da votação. Segundo os relatórios (CC,1994; 1997; 2000; EU, 2006; OEA, 2009; 2012; 2015), o transporte de material sensível; a existência de instrumentos confiáveis de contagem e tabulação e ausência de violência eleitoral, são boas práticas que se instalaram no país desde os primeiros processos eleitorais, tendo as recomendações somente reforçado a necessidade de que elas se mantivessem. Elas são importantes, especialmente, para que não haja contestações sobre a integridade do processo eleitoral, ao mesmo tempo em que sinalizam para a comunidade internacional, que o organismo eleitoral atendeu a critérios minimamente democráticos.

Entre as recomendações que foram implementadas, mas que reincidiram em alguns momentos, também na etapa pós-eleitoral, está a pouca divergência entre resultados preliminar e final. Os relatórios (EU, 2006; OEA, 2012) apontaram que houve falhas somente em dois processos eleitorais no período 
estudado. A introdução de um sistema estatístico de divulgação de resultados preliminares pelo organismo eleitoral, se mostrou efetivo, em comparação aos resultados de contagens paralelas de organizações da sociedade civil. $O$ Programa de Resultados Eleitorais Preliminares (Prep), ganhou maior importância e veio a substituir contagens mais informais, após ser apontado pelos observadores que outras contagens, que não a do organismo eleitoral, era um dos principais focos de divergências entre os candidatos.

Entre as medidas que foram implementadas, mas que deixaram de sê-lo está a presença de todo o material sensível e dos membros da mesa localizadas no dia da votação. Localizada no dia da eleição, foram vistas como uma melhoria após as observações das missões, porém nas eleições de 2009 a 2015, o que se viu foi novamente a ausência desses recursos nos centros eleitorais. $O$ mesmo pode ser dito para a facilidade de acesso aos centros de votação. Em trabalho de campo realizado durante a jornada eleitoral legislativa de 2015, no México D.F., havia muitos centros eleitorais sem nenhuma identificação, ou que haviam sido deslocados para outros locais. Muitos, inclusive, não permitiam o acesso de pessoas com deficiência, por se localizarem em terrenos elevados ou sem acesso via transporte público; muitas ainda foram montadas em garagens mecânicas e estacionamentos de prédios comunitários.

Em 2009, a OEA fez recomendações para que a questão fosse resolvida, sobretudo, porque muitos centros eleitorais não possuíam as mesmas comodidades apresentadas por outros. Segundo seu relatório, os observadores indicaram que viram centros eleitorais muito bem instalados em escolas, enquanto outros, nas proximidades, se encontravam em casas particulares, garagens privativas ou em becos sem saída (OEA, 2009).

Já em 2015, observadores relataram que centros eleitorais não conseguiram ser abertos porque o responsável pela sua abertura não havia sido encontrado, de modo que os chefes desses locais acabaram por buscar espaços alternativos, tendo um deles, inclusive, aberto a própria garagem de sua casa para a votação, não oferecendo qualquer estrutura básica de comodidade aos eleitores (OEA, 2015).

No entanto, a maior preocupação é com o segredo de voto, visto que, muitas vezes ele não foi garantido. Em 1994, apesar das campanhas promovidas pelo IFE para promoção do segredo de voto, este não foi respeitado nos centros 
de votação. Contudo, isso não fez com que os eleitores deixassem de votar. Em 2006 e 2015, o IFE repetiu as mesmas campanhas de conscientização e incentivo à participação cidadã, no qual destacava a importância do segredo de voto e os direitos dos votantes. Houve, porém, indicações nos relatórios de que, apesar da baixa participação, este era um direito que deveria ser garantido e, assim, uma vez mais, a violação do segredo de voto não foi determinante para anular o processo eleitoral.

Tabela 21 - Taxa de participação popular nos processos eleitorais mexicanos, por tipo de eleição, data, votos e eleitores registrados, a partir dos anos 2000

\begin{tabular}{lcccc}
\hline \multicolumn{1}{c}{ Tipo de eleição } & Data & Votos & $\begin{array}{c}\text { Eleitores } \\
\text { registrados }\end{array}$ & $\begin{array}{c}\text { Taxa de } \\
\text { Participação }\end{array}$ \\
\hline Câmara dos & $07 / 06 / 2015$ & $39,872,757$ & $83,563,272$ & $47.72 \%$ \\
Deputados & $01 / 07 / 2012$ & $51,052,668$ & $77,547,511$ & $65.83 \%$ \\
Câmara dos & $01 / 07 / 2012$ & $50,310,328$ & $77,547,511$ & $64.88 \%$ \\
Deputados & $01 / 07 / 2012$ & $50,323,153$ & $77,738,494$ & $64.73 \%$ \\
Senado & $05 / 07 / 2009$ & $34,126,794$ & $71,351,123$ & $47.83 \%$ \\
Presidente & $02 / 07 / 2006$ & $41,762,798$ & $71,374,373$ & $58.51 \%$ \\
Câmara dos & $02 / 07 / 2006$ & $41,195,198$ & $71,374,373$ & $57.72 \%$ \\
Deputados & $02 / 07 / 2006$ & $41,791,322$ & $71,374,373$ & $58.55 \%$ \\
Senado & $06 / 07 / 2003$ & $26,968,371$ & $64,710,596$ & $41.68 \%$ \\
Câmara dos & $02 / 07 / 2000$ & $37,610,715$ & $58,789,209$ & $63.98 \%$ \\
Deputados & $02 / 07 / 2000$ & $37,603,923$ & $58,789,209$ & $63.96 \%$ \\
Presidente & $02 / 07 / 2000$ & $37,424,301$ & $58,789,209$ & $63.66 \%$ \\
Câmara dos & Deputados & & & \\
Senado & Presidente & & \\
Câmara dos & Deputados & & & \\
\hline Fonte: IFES, 2016. & & & & \\
\hline
\end{tabular}

Fonte: IFES, 2016.

Também merece destaque a possibilidade de retrocessos na administração eleitoral por parte do IFE. Serra (2012) argumenta que apesar do organismo ter alcançado notória credibilidade e autonomia em 1997, ele fora novamente preenchido por uma série de representantes de partido, em 2003. Da mesma forma, as reformas eleitorais de 2007, removeram os conselheiros eleitorais, antes mesmo de finalizado o período de seus mandatos, além de outras mudanças.

Freidenberg (2009) identificou algumas forças políticas destoantes que tentavam se impor durante as reformas de 2007. De um lado, a coalizão 
declinante, liderada pelo PRI, que promoveu reformas inclusivas com o intuito de melhorar seus níveis de legitimidade e, de outro, a coalizão perdedora desafiante, na forma do PRD, com expectativas ascendentes, pressionava para que suas preferencias fossem maximizadas, em um contexto de grande incerteza com respeito ao comportamento dos atores. Por fim, havia a coalizão governante, o PAN, que enfrentava o risco de não poder levar adiante a tarefa de governar, em função dos conflitos surgidos com a eleição de 2006.

O PRI havia perdido legitimidade, porém o PAN, que elegeu Felipe Calderón (2006 - 2012), não conseguiu maioria legislativa, sendo a reforma eleitoral a melhor saída para alcançar a governabilidade desejada.

As recomendações das missões foram menos implementadas também, com relação aos procedimentos dos centros de votação, que em geral têm práticas distintas uns dos outros. É o caso, por exemplo, dos centros de votação especiais. Esses centros foram criados como alternativas ao recebimento de votos daqueles eleitores que estão temporariamente afastados dos distritos eleitorais, aos quais correspondem seus domicílios. Apesar de recomendações recorrentes, de que fosse revisto o formato de tais centros, como o respeito à restrição de cédulas de votação a até 750 eleitores (OEA, 2015).

Para Serra (2012), essas implementações mostram como instituições democráticas podem ser fracas, sobretudo em democracias de Terceira Onda. Muitos autores já mencionaram a necessidade de consolidação de instituições, como uma forma de garantir que o novo regime não seja derrubado por um presidente despótico ou por um partido dominante (O'Donnell, Schmitter e Whitehead, 1986). Destarte os esforços empregados, práticas não democráticas são comuns na região. Freidenberg (2015) argumenta que os principais problemas com a governança eleitoral, na América Latina, são: baixa profissionalização de integrantes de centros eleitorais; baixa independência partidária dos órgãos eleitorais; baixa capacidade de fiscalização de campanhas; problemas nos registros de eleitores; demora na entrega de resultados etc.

Assim, Holzner (2011) argumenta que a qualidade da democracia mexicana deixa a desejar, pois para ele, há uma diferença entre aquilo que se aspirava com a transição, daquilo que realmente foi alcançado. Entre seus sucessos estão a realização de reformas eleitorais e a ascensão de competição política. 
Mesmo com os avanços alcançados, a democracia no país ainda é vulnerável à um retorno ao autoritarismo. Buendía e Somuano (2003) afirmam que os cidadãos mexicanos não confiam no voto que depositam nas urnas, em virtude de uma década de eleições fraudulentas. Assim como muitas das democracias eleitorais da região, o México teve uma democratização ao revés, ou seja, se estabeleceram eleições livres e competitivas antes de serem criadas instituições básicas. Desse ponto de vista, os autores apontam três caminhos: ou essas democracias podem se consolidar, regressar ao autoritarismo ou persistir de modo indefinido como democracias eleitorais.

Por muitos anos, os mexicanos participaram de eleições nas quais a fraude eleitoral, corrupção e irregularidades eram comuns. Para os autores, é provável que isso tenha afetado a confiança dos cidadãos nas instituições, minando a legitimidade do voto como um instrumento de participação (idem).

Holzner (2011) chama atenção para o fato de que mesmo as percepções de fraude tendo diminuído para o período de 1997 a 2000, após o maior fortalecimento do IFE, no período seguinte, a percepção de que o processo havia sido fraudulento cresceu para os eleitores de todas as faixas de renda do país nas eleições seguintes (idem).

Outro ponto que passou a aparecer com mais frequência nos relatórios foi o papel dos programas sociais como uma forma de coação de eleitores. Em 2006, a União Europeia citou como uma das principais fontes de preocupação de partidos políticos, sociedade civil e representantes eleitorais, durante 0 período pré-eleitoral, a possibilidade de compra de votos, mediante a oferta de acesso a um programa social, junto a intimidação de votantes. No relatório, os observadores disseram que "o uso arbitrário dos programas sociais tem sido um problema no passado que afetou sobretudo os grupos sociais mais vulneráveis do país, como as populações indígenas e os idosos" (UE, 2006, p. 25).

Segundo Cornelius (2002), embora existam outras formas de coação, a exemplo da compra de votos - que foi registrado como o abuso mais sério das eleições de 2000 -houve uma modernização na compra e coerção de eleitores nas eleições mexicanas, que deixaram de se concentrar no dia da votação, para ocorrer no período pré-eleitoral. Em outras palavras, o autor chama a atenção para o refinamento das técnicas de manipulação, utilizadas pelos partidos mais tradicionais, como uma das consequências não intencionais do aumento no 
monitoramento de eleições (Hyde, 2008; Beaulieu e Hyde, 2009; Hartlyn e McCoy, 2006; Simpser, 2008).

O uso de programa eleitorais como um instrumento de manipulação eleitoral no período antes do dia da votação não é algo novo no país, uma vez que, o PRI, já utilizava esse meio para manter para manter sua vantagem política (Cornelius, 2002). Em 2000, o autor investigou a eficácia desse tipo de manipulação na compra de votos, e, descobriu que ela havia deixado de ter o mesmo efeito de antes. Ele defende que o votante mexicano à época se sentiu mais propenso a votar no candidato presidencial da oposição, no caso do PAN, porque tal violação da integridade do processo eleitoral se mostrara mais séria ao eleitor quando cometida pelo $\mathrm{PRI}$, que por outros partidos.

Assim, mesmo com as recomendações, a tentativa de troca de votos por benefícios em programas sociais continua uma estratégia bastante praticada no país, tendo inclusive, o Partido Verde Ecologista do México (Pvem), utilizado essa estratégia, nas eleições de 2015, conforme observações de campo, ao oferecer bolsas de estudos em troca de votos para cargos do legislativo.

Ao tratar das diferentes estratégias de manipulação mais comuns nas eleições mexicanas, Calingaert (2006) cita: paraquedistas e carrosséis, durante a votação, e alquimistas, durante o processo de contagem e tabulação. O voto múltiplo aparece ainda como um problema a ser eliminado dos processos eleitorais mexicanos. É comum que eleitores credenciados consigam votar mais de uma vez, ou, até mesmo, votar em nome de um parente falecido ou não assinar a lista de eleitores. Esse é o caso dos paraquedistas, que parecem cair do céu nos centros de votação, para depositar cédulas nas urnas eleitorais. Já os carrosséis consistem na prática do transporte de um conjunto de eleitores até os centros de votação, para votação em um único candidato. Por fim, os alquimistas são aqueles agentes do partido no poder que, durante a tabulação dos votos, são capazes de converter uma derrota, em vitória. Uma das estratégias utilizadas pelos alquimistas é a de preencher as urnas com votos para a situação, durante o seu transporte dos centros provinciais até o organismo eleitoral (idem).

Durante as eleições de 1994, os visitantes estrangeiros não acusaram a presença de práticas ilegais, como coação de eleitores, no dia da eleição. Porém, segundo Fox (1996) os estrangeiros visitaram somente áreas urbanas 
modernas, nas quais as eleições foram relativamente limpas, ao contrário das áreas rurais, sobretudo no Sul (Chiapas, Guerrero, Michoacán, Oaxaca, Puebla, Tabasco e Veracruz), em que observadores domésticos ressaltaram uma alta incidência de violações contra o direito de voto dos cidadãos, como o carrossel e a não garantia do segredo de voto.

Não é à toa que nas últimas eleições realizadas no país, em junho de 2015, uma parte da missão da OEA foi deslocada para o Sul - evidenciando a maior abrangência do monitoramento no país -, onde puderam presenciar a queima de urnas e episódios de violência eleitoral (OEA, 2015).

É possível apontar a maior especialização do processo de monitoramento, como um fator que modificou o conteúdo dos relatórios divulgados pelas missões. Em 1994, as observações se limitaram aos problemas relacionados à confiança no processo eleitoral, com ênfase no dia da votação. Em 1997, os observadores ampliaram suas atividades de observação e fizeram 0 monitoramento também das campanhas eleitorais ${ }^{84}$, uso de programas sociais, educação cívica e outros. Em outras palavras, passaram a incluir em seus relatórios, de forma mais incisiva, as etapas pré e pós-eleitorais.

Com a chegada dos anos 2000 e as várias reformas eleitorais realizadas, a preocupação com a confiança no processo deixou de ser algo central, para dar lugar a temas como o financiamento dos partidos políticos e as condições de campanha, se impactadas ou não por tentativas de intimidação e/ou violência eleitoral. $\mathrm{O}$ ano de 2003 seguiu a mesma tendência da eleição anterior, sendo que, o foco das observações passou a ser o do período pré-eleitoral, visto que a expectativa era que possíveis violações das regras eleitorais ocorressem aí (Hyde e O'Mahony, 2005). O processo de 2006, que recebeu o maior número de visitantes estrangeiros até o momento (Gibbran, 2010; Santa-Cruz, 2005), abrangeu uma maior gama de temas, como por exemplo, o voto de estrangeiros residentes no exterior e a polêmica envolvendo a contagem de votos, que levou a uma margem de diferença muito pequena, entre os candidatos que mais se destacaram ao longo do processo de escolha do novo presidente ${ }^{85}$.

\footnotetext{
${ }^{84}$ No México, o período de campanhas eleitorais dura noventa dias, no caso de eleições gerais, e sessenta dias, para eleições legislativas, sendo que ambas devem finalizar três dias antes do dia da votação.

85 Felipe Calderón, do PAN, recebeu aproximadamente, $35,89 \%$ dos votos, ao passo que, Andrés Manuel López Obrador, do PRD, obteve 35,31\% dos votos (INE, 2016).
} 
Em 2009, o processo de contagem também ganhou destaque nos relatórios, assim como, as recomendações passaram a se concentrar no dia da eleição, uma vez, que esse é o período dentro do processo eleitoral, que as recomendações têm menor impacto, conforme Quadro 10. As recomendações se voltaram, principalmente, para: atuação dos membros de mesa, instruções aos eleitores de como e onde votar, preenchimento das atas e localização e condições dos centros de votação, com ênfase na acessibilidade a pessoas com dificuldade de locomoção, entre outras.

Nas eleições de 2012, o PRI retorna à sua popularidade, assumindo mais de $40 \%$ das cadeiras do Congresso, além de ter conseguido eleger Enrique Peña Nieto como presidente (INE, 2016). Nesse momento, os relatórios elogiaram a atuação do IFE na condução do processo eleitoral, porém relataram o ambiente de desconfiança, marcado por uma série de denúncias de compra massiva de votos, por representantes de partidos da oposição (UE, 2012; OEA, 2012). Não obstante, as recomendações acabaram por refletir esse ambiente, tendo os observadores sugerido penas mais severas com vistas à redução na frequência de tais práticas (idem).

Após as reformas eleitorais efetivadas em 2013 e 2014, o governo mexicano realizou eleições legislativas que, segundo os relatórios das missões da União Europeia e OEA, contou com ampla igualdade de gênero, tanto na composição das mesas eleitorais, quanto, na participação popular. Esse foi um dos temas mais abordados nos relatórios, assim como, os atrasos na abertura das urnas e a dificuldade de acesso dos eleitores aos centros de votação. Uma vez mais o $\mathrm{PRI}$ recebera a maioria dos votos e a violência se manteve no Sul do país, ambos os pontos foram apresentados como temas muito relevantes do ponto de vista da manutenção da qualidade dos processos eleitorais no país (UE, 2015; OEA, 2015).

Assim, as observações realizadas no México corresponderam a cada uma das etapas de especialização do monitoramento internacional de eleições, conforme Boneo (2007). Segundo o autor, inicialmente, a observação tinha como foco contribuir para a promoção de eleições livres, transparentes, limpas e periódicas. As eleições de início dos anos 1990 careciam de legitimidade, em virtude do caráter transitório, que apresentavam, de modo que, a observação se voltou para esse fim, ao monitorar se os governos em questão cometiam práticas 
irregulares ou fraudulentas. A ênfase recaiu na imparcialidade do organismo eleitoral em organizar as eleições, com eficiência e segurança, sem votos duplos ou descaminho de materiais sensíveis.

Com a chegada dos anos 2000, o objetivo passou a ser o aperfeiçoamento da boa governança eleitoral, com maior preocupação sobre a qualidade da organização do processo eleitoral, ao qual se somaram novos temas, como a fiscalização do financiamento ilegal de campanhas e a resolução de conflito póseleitorais (Gibbran, 2010).

Para Boneo (2007), o impacto da observação ocorre em dois planos: político e técnico. Sua classificação tem a ver com a própria natureza da observação, que, embora todas tenham o componente técnico de diferente magnitude, é na parte política que podem ser identificados variados graus de influência ou impacto.

Ao contrário da observação doméstica, a observação internacional tem menor impacto, sobretudo, porque, em alguns casos são vistas como uma forma de interferência externa, ou mesmo, devido seu caráter limitado de atuação por legislações, a exemplo da Nicarágua, Venezuela e Chile, que permitem somente o acompanhamento internacional de eleições.

O autor cita o caso das eleições gerais de 1994, que geraram enorme interesse da comunidade internacional, em um contexto interno marcado pela morte de um candidato à presidência da república e o início dos levantes zapatistas, no Sul. É a partir daí que os observadores passaram a ser permitidos no país, embora os estrangeiros já realizassem observação informal anteriormente (Santa-Cruz, 2005). Assim, "a presença de uma grande quantidade de observadores internacionais da América e Europa contribuiu para acelerar uma série de reformas eleitorais, que melhoraram significativamente as eleições no país (...)" (Boneo, 2007, p. 1104). O impacto avaliado pelo autor revelou que ocorreram mais melhorias no âmbito técnico que no político, resultado também observado em nosso estudo, uma vez que práticas a exemplo da segurança do voto e a coação de eleitores, continuam sendo denunciadas pelos observadores, ao passo que aspectos mais técnicos, como a criação de campanhas de conscientização política e de instrumentos confiáveis de contagem e tabulação de votos, foram aprimorados nos últimos anos. 
Os organismos eleitorais podem até realizar eleições tecnicamente impecáveis, porém caso não seja garantida a segurança dos eleitores e do Estado de Direito, é muito difícil que as elas sejam consideradas boas. No caso das eleições legislativas no México, em 2015, houve dificuldade do IFE em coordenar todos os eventos relacionados à garantia da livre circulação de candidatos e eleitores, sobretudo em Oaxaca, Chiapas e Michoacán, em que urnas foram queimadas e o medo impediu a ida de muitos eleitores, até os centros de votação. Também houve dificuldade na identificação, punição e erradicação de más práticas como a compra de votos e utilização de programas sociais como estratégia de barganha, por mais, a exemplo do que fez o Pvem (OEA, 2015).

Importante citar ainda impactos que vão além do dia da eleição, mais especificamente, o fortalecimento institucional e a cultura política. Sobre o primeiro ponto, os relatórios das primeiras eleições observadas citavam como aspecto a ser melhorado, a maior independência do organismo eleitoral (CC, 1994; Ifes, 1994), item que foi incluído nas reformas realizadas em 1996, e que depois foi mencionado pelos observadores, como base do sucesso das eleições seguintes (Ifes, 1997; IRI, 2000). Em se tratando da cultura política, a prática de compra de votos, ainda que presente nas eleições mexicanas, deixou de ser vista como uma prática corriqueira, visto que havia sido amplamente utilizada pelo PRI, ao longo dos anos em que o partido dominara a cena política (Lean, 2012; Eisenstadt, 2003; Cornelius, 2000), para uma irregularidade que ameaça a consolidação democrática do país.

Esses impactos só foram possíveis porque a própria natureza da observação se modificou ao longo dos anos. Gibbran (2010, s. p.) menciona que "... as atividades de observação eleitoral alcançaram um alto nível não
somente pela relevância dos temas observados, senão pela mais
ampla cobertura geográfica em todo o território nacional e por ter
iniciado suas atividades de observação com vários meses de
antecipação ao desenvolvimento e verificação da jornada eleitoral.
Também se destacou o trabalho mais profissional dos visitantes
estrangeiros."

Ou seja, a medida que as más práticas se tornaram mais elaboradas (Hyde, 2011; Hoyos, 2014; Simpser e Donno, 2012), também se modificaram as missões, com o intuito de não somente monitorar a existência ou não de irregularidades, como também promover a boa governança eleitoral, 
aumentando a qualidade das eleições e mantendo sua integridade frente aos votantes.

O impacto da observação também pode ser verificado com relação à legitimidade que ele traz ao processo. Ao contrário dos observadores domésticos que transmitem informações ao público nacional, sendo esta sua principal audiência, os observadores internacionais são a fonte mais consultada por meios de comunicação externos e governos em geral, sobre a qualidade das eleições.

Embora seja possível observar que muitas medidas foram implementadas a cada ano, em se tratando do período pré-eleitoral, o ano de 2009 merece destaque, pois representou uma queda importante dentro do quadro de análise.

A explicação para essa mudança no padrão de recomendações implementadas por ano, reside, sobretudo, nos quesitos de recomendações sobre ausência de grupos armados, ausência de focos de violência eleitoral e ausência de campanhas de desmobilização de eleitores. Esses quesitos que há anos não eram citados nos relatórios, apareceram como recomendações importantes, em função do aumento dramático da violência associada ao crime organizado, que teve reflexos nas eleições. Em 2009, esse tipo de violência havia crescido muito no país, apesar das tentativas de Calderón de enviar militares para as áreas de maior dominação do crime organizado, na tentativa de diminuir as mortes relacionadas, sobretudo, ao tráfico de drogas.

No entanto, a escalada da violência no México acabou gerando um descontentamento interno crescente de atores sociais, econômicos e políticos com sua estratégia de guerra contra o narcotráfico, que vinha se mostrando ineficaz. $E$, durante o período pré-eleitoral surgiram denúncias de que alguns candidatos haviam recebido dinheiro do narcotráfico, que se traduziram, mais tarde, em enfrentamentos nas ruas entre simpatizantes do PRD e do PRI. Da mesma forma, os observadores relataram a presença de grupos armados, "que atacaram famílias em seu deslocamento até o centro de votação, provocando a morte de doze pessoas, entre elas um jovem e um vereador do PRD" (OEA, 2009 , s. p.). Também foram relatados casos de mensagens com ameaças aos candidatos do PAN e PRI, que, segundo oficiais de Justiça, envolvidos no processo eleitoral, estavam ligadas ao narcotráfico (idem).

Outro ponto que reapareceu nas eleições de 2009, foram as campanhas de desmobilização de eleitores, que consiste nas tentativas de desestimular os 
eleitores a votar no dia da eleição. Essas campanhas foram executadas através de meios não regulados, como telefone e internet, dificultando seu controle por parte do IFE e chamaram a atenção dos observadores, que recomendaram a maior atenção para com esse tipo de ativismo, que poderia ter consequências importantes, como o aumento do absenteísmo, nas eleições (ibidem).

Por fim, cabe mencionar que os observadores contribuíram, sobretudo, não somente pelas recomendações de fizeram e que, depois, foram implementadas, sobretudo, nos períodos pré e pós-eleitorais, como também em dois aspectos importantes da cultura política mexicana. Sem dúvida, os observadores desempenharam um papel de suporte na criação de uma rede de observação doméstica de eleições (Lean, 2007; 2012; Kelley, 2012), ao mesmo tempo em que contribuíram para a melhoria de sua reputação no cenário internacional.

\subsection{Considerações finais}

O PRI, partido hegemônico do México, fundado em 1929, governou o país por mais de 70 anos, sob um tipo especial de regime não-democrático: o autoritarismo eleitoral. As autocracias eleitorais têm sua legitimidade baseada na realização de eleições periódicas, que contam com algum grau de pluralismo, mas não atendem padrões mínimos democráticos. Violações de normas liberaisdemocráticas podem se manifestar no ambiente político dos países com a limitação de liberdades civis (Freedom House, 2016), restrições à candidatura de partidos e candidatos, fraude eleitoral, compra de votos e coerção de eleitores e um ambiente que privilegiava o partido incumbente.

No entanto, a crise econômica que abateu o país em meados dos anos 1980, aumentou a popularidade de partidos da oposição, que seriam a alternativa frente a ineficiência do PRI, de encontrar uma saída para os problemas econômicos. Com isso, os partidos de oposição foram paulatinamente acumulando força, em sucessivas rodadas de eleições, ao mesmo tempo em que negociavam reformas rumo à democratização.

Em contraste com a tendência que marcou a Terceira Onda na América Latina, de transições de governos autoritários militares que culminaram na 
realização de eleições fundacionais, a transição política mexicana progrediu lentamente através de reformas que transformaram suas práticas eleitorais (Magaloni, 2006).

A competição eleitoral também cresceu e pode ser visualizada através de alguns eventos marcantes. Em meados de 1980, partidos da oposição alcançaram a vitória em eleição municipal e nos anos 2000 os governadores desses partidos se encontravam distribuídos em grande parte dos estados mexicanos. Embora o PRI, historicamente, dominasse com folga as cadeiras da Câmara de Deputados mexicana, em 1997, pela primeira vez, sua maioria absoluta foi derrotada, abrindo oportunidades para que partidos da oposição ocupassem seus assentos. No mesmo ano, o PRI também perdeu maioria no Senado (idem).

Não obstante sua trajetória diferenciada, a desconfiança do eleitorado com relação aos processos eleitorais que ocorreram durante a transição mexicana, contribuiu para mudanças importantes com relação à condução desses processos. O convite à observação internacional ocorreu na esteira de reformas que buscaram aumentar a credibilidade do processo eleitoral não somente frente aos cidadãos, como também perante a comunidade internacional.

A observação tem servido não somente aos interesses políticos mexicanos, mas sobretudo, como indicação para o recebimento de recursos financeiros de instituições promotoras da democracia, como o Banco Mundial, e também como auxilio na maior articulação da sociedade civil, mediante o incentivo à criação de organizações domésticas de observação eleitoral.

Além desses papeis, a observação também contribuiu para as reformas eleitorais no país, uma vez que algumas de suas recomendações foram implementadas, posteriormente. O resultado do índice de boa governança eleitoral para o México poderia ser maior caso arraigadas más práticas não minassem o andamento da jornada eleitoral. Assim, os índices de governança eleitoral para o período pré e pós-eleitorais são melhores, do que os do dia da eleição que os do dia da votação, principalmente porque estão mais ligados à organização do processo eleitoral e divulgação de resultados, respectivamente. A fase de condução (dia da votação) continua a ser um desafio, especialmente porque muitas das más práticas estão concentradas aí e dependem muito mais 
de mudanças na cultura política que propriamente de alterações na legislação e demais regras eleitorais.

Finalmente, ao contrário do que esperávamos, que era um impacto mais alto das recomendações das missões para o país, obtivemos um resultado mediano, sobre o qual argumentamos que se deve muito mais a heranças do período autoritário eleitoral, do que das práticas que poderiam levar o país rumo a se tornar uma democracia liberal. 


\section{CONCLUSÃO}

A observação eleitoral internacional tornou-se uma ferramenta muito comum das organizações internacionais de promoção da democracia. Da mesma forma, a comunidade internacional passou a ver a observação como um item importante na avaliação do desenvolvimento democrático de uma nação.

Os observadores que tem profissões variadas assim como variadas trajetórias de vida (Crochetet, 2013), têm sido deslocados de seus países de origem para países em transição, ainda sujeitos a práticas eleitorais manipuladas e fraudulentas, mas onde eleições monitoradas conquistam o respeito internacional e muitas vezes significam o primeiro e maior passo no processo de democratização.

$\mathrm{Na}$ América Latina, a observação internacional se faz presente em muitas das recentes democracias eleitorais que transitaram de diferentes regimes autoritários, como o caso do Haiti, por muito tempo sob a regra da família Duvalier, ou o do México, que por 70 anos sob o predomínio de um partido único, o PRI.

O monitoramento internacional de eleições tem suas origens nos valores da boa governança. De modo mais simples, as eleições são o pilar que permite a uma nação construir o governo representativo de sua vontade. A observação internacional contribui para esse processo ao avaliar se as eleições atendem a normas mínimas de democracia. Cada uma das organizações internacionais que realizam a avaliação dos processos eleitorais tem seus próprios procedimentos e preparo. No entanto, todas emitem seu relatório para uma ampla gama de atores, tanto domésticos quanto internacionais, que os consideram uma fonte essencial de consulta no que se refere à credibilidade $\mathrm{e}$ legitimidade de um pleito.

Em muitos casos, o desenvolvimento democrático leva tempo e esforço, de modo que não devem ser criadas expectativas quanto ao surgimento de respostas rápidas nessa área. É necessário que haja um grande grau de compromisso para que as mudanças ocorram.

Esse trabalho buscou avaliar a governança eleitoral e o impacto das recomendações das MOEls para o seu aprimoramento, em países que ainda apresentam uma série de características de regime autoritário, mas que 
possuem qualidades democráticas mínimas, tornando-os espaços de experimentação sem igual. Consideramos em nossa pesquisa, que é nesses países de regime híbrido que a observação poderia contribuir mais e melhor, visto que, há muito o que mudar e construir. Muitas vezes, nas democracias liberais, as MOEs servem mais a objetivos de correção de irregularidades, que propriamente de avaliação (Norris, 2013).

No caso do México e Haiti, em ambos os países a aprovação internacional é muito importante. Suas economias estão muito ligadas ao cenário externo e qualquer abalo em suas imagens de países democráticos, poderia incorrer em perdas econômicas importantes, a começar pelos financiamentos de agências internacionais.

No Haiti a presença dos observadores contribuiu, ainda que modestamente, para a melhoria de algumas práticas eleitorais, sobretudo no dia da eleição. Sua classificação pelo índice de governança eleitoral aqui usado, coloca-o no limite inferior do estrato médio.

No caso mexicano, vimos que, apesar da influência relativamente maior das missões nas práticas eleitorais desse país, seu índice de boa governança eleitoral, coloca-o no limite superior do estrato médio. Foram introduzidas reformas eleitorais que impactaram, principalmente, as fases pré e pós-eleitoral. O dia da eleição continuou concentrando as arraigadas más práticas eleitorais, mais difíceis de serem superadas.

Sobre a atuação dos observadores percebemos que elas foram mais visíveis na construção de capacidades nacionais, necessárias à melhoria de sua governança democrática, para o caso mexicano, e, no Haiti, através de sua presença nos centros eleitorais, no dia da votação, como uma forma de inibir fraudes e manipulações. De fato no México, a observação foi além do esperado ao contribuir para o fortalecimento de organizações domésticas de monitoramento eleitoral, cujo maior expoente é a Aliança Cívica (Lean, 2007; 2012). O mesmo desenvolvimento não ocorreu no Haiti onde apesar de existirem, as organizações domésticas de observação eleitoral não conseguiram assumir a mesma relevância que os observadores internacionais.

Do México, o PRI permitia instituições minimamente pluralistas, que facilitaram sua transição e adaptação a novos tempos. Contudo, não havia 
nenhum espaço para instituições mais plurais, já que a política era dominada por um líder autoritário, que colocava seus aliados à frente da condução do país.

Com relação às recomendações, obtivemos resultados melhores para 0 México, do que para o Haiti. Isso pode ser explicado pelas reformas eleitorais que foram realizadas no México, que, muitas vezes, incluíram as recomendações dos observadores na agenda eleitoral (Kelley, 2012). As reformas foram realizadas em 1987, 1990, 1993, 1994 e 1996, uma verdadeira revolução do processo eleitoral no país, que introduziram mudanças como o fornecimento de novas credenciais aos eleitores, oficiais eleitorais escolhidos de forma aleatório entre a população, urnas de votação transparentes, a maior independência do organismo eleitoral e uma lista nominal de eleitores que contem a fotografia dos eleitores habilitados a votar (Schedler, 2001).

Importante notar, que o último ponto foi motivo de controvérsia nas eleições legislativas de 2015, porque a mesma lista que é entregue aos membros das mesas, com nome e foto dos eleitores, é disponibilizada também aos representantes de partidos políticos, que monitoram os centros eleitorais (OEA, 2015). Segundo os observadores, essa prática poderia ser um risco aos eleitores, visto que, durante o estudo de campo, foi possível observar a checagem dos eleitores que votavam, com as listas com nome e foto dos votantes. Em outras palavras, tendo em mãos essas informações, os representantes dos partidos políticos, poderiam fazer a checagem daqueles que votaram ou não, representando uma ameaça ao segredo de voto (idem).

Sobre o segredo do voto é importante enfatizar que há diferenças com relação aos dois países. No Haiti, em virtude, muitas vezes, da precariedade dos locais de votação, é difícil a garantia do segredo de voto, porém isso não diminui a credibilidade do processo, visto que, para os observadores, a preocupação maior com os processos eleitorais no país se encontra na sua organização, mais que em seu andamento. Já no México, após décadas de dominação do PRI, que constantemente recorreu à compra de votos e manipulação de resultados para se manter no poder, há uma preocupação maior, por parte dos observadores, que frequentemente mencionam esse como um dos pontos que merecem maior atenção dos oficiais eleitorais, e que poderia minar a integridade dos processos eleitorais mexicanos. 
Segundo Merloe (2015), a integridade de uma eleição reside em uma gama de processos, aí incluídos, por exemplo, os procedimentos utilizados para o registro de candidatos e votantes e a precisão dos resultados finais. As missões têm como uma de suas tarefas assegurar que incumbentes não violem esses processos, através do mau uso do poder que detém. Embora nenhuma eleição possa ser perfeita, indicações positivas em toda a gama de processos relacionados com as eleições, apontam para a democratização do país, um respeito aos direitos humanos, incluindo a liberdade dos cidadãos para fazer escolhas políticas (idem).

A promoção de normas eleitorais democráticas é essencial para evitar a ressurgência de regimes autoritários em países que se encontram em transição (Carothers, 2002), sobretudo democracias eleitorais como o Haiti e México (Freedom House, 2016). Uma vez que práticas democráticas se fortalecem torna-se mais difícil esconder aspectos mais frágeis, fraudulentos ou manipulados dentro dos processos eleitorais.

Embora o relacionamento desses dois países com a observação internacional de eleições já seja longo, por vezes, os métodos aí, poderiam ser revistos, dadas as novas ameaças de fraude e outros desafios que se impõem pelos diferentes contextos políticos. Da mesma forma, experiências exitosas de criação de capacidades estatais domésticas como a do México, poderiam ser melhor avaliadas, no que se refere à adequação de aplicá-las em outros países, como o Haiti. O governo haitiano tentou investir na criação de uma rede doméstica de observadores eleitorais, porém sem sucesso. É possível que com maiores incentivos, sobretudo, das próprias missões internacionais que participam dos pleitos em cada país, possam ser feitas recomendações no sentido do fortalecimento das capacidades estatais domésticas.

Os cidadãos têm direito a eleições autênticas, porém as boas eleições só ocorrem em contextos institucionais fortes, em que as condições de sobrevivência básica da maioria da população estão asseguradas; as regras eleitorais são imparciais, conhecidas e respeitadas por todos; os organismos eleitorais possuem legitimidade frente aos demais atores políticos, sobretudo os partidos políticos; há assegurada liberdade de circulação etc (Merloe, 2015).

Por fim, a observação internacional se popularizou na Terceira Onda mediante o convite de autocracias eleitorais (Hyde, 2011) e, mais recentemente, 
tem servido a muitos governos de democracias eleitorais, que não possuem as mesmas condições existentes em democracias liberais de legitimar seus regimes. Ao convidarem estrangeiros, para que eles participem de seus pleitos, há a expectativa de que seus regimes sejam reconhecidos internacionalmente.

De uma forma geral, a observação internacional de eleições tem sido a cada dia mais reconhecida internamente como uma alternativa popular frente à possibilidade de manipulação de resultados, pelos organismos eleitorais. A tendência, portanto, é que nos próximos anos ela seja mais frequente, conforme cresce o número de democracias instáveis no mundo. 


\section{REFERÊNCIAS BIBLIOGRÁFICAS}

ACE PROJECT. "Electoral Cycle". What is the Electoral Cycle?, s.d. Disponível em: http://aceproject.org/electoral-advice/electoral-assistance/electoral-cycle. Acesso em: 3 Jun. 2016.

. "Electoral Integrity". The ACE Encyclopaedia, 2012. Disponível em: http://aceproject.org/ace-en/topics/ei/eid/eid06/default. Acesso em: 20 out. 2016.

Projeto de Administração e Custo das Eleições. Comparative Data. Disponível em: http://aceproject.org/epic-en. Acesso em: 23 out. 2016.

ALVAREZ, R. Michael; HALL, Thad E. "Building secure and transparent elections through standard operating procedures". Public Administration Review, v. 68, n. 5, p. 828-838, 2008.

ANGLIN, Douglas. "International Election Monitoring: The African Experience". African Affairs, v. 97, n. 389, p. 471-495, 1998.

BACHELARD, Jérôme Y. Press. "Pressure Struggles Behind Elections and Coups: Madagascar's 2001-2002 and 2009 Democratization Crises in Comparative Perspective". Annual Congress of the Swiss Political Science Association, University of Geneva, 7-8 Janeiro 2010, 26 p.

BADIE, Bertrand; BERG-SCHLOSSER, Dirk; MORLINO, Leonardo. "Election Observation" In: International Encyclopedia of Political Science. United States: SAGE Publications, p. 722-725, 2011.

BANCO MUNDIAL. "Governance". The World Bank's Experience, Washington, DC: The World Bank, 1994.

World Bank Open Data. 2016. Disponível em: http://data.worldbank.org/. Acesso em: 25 out. 2016.

BBC. Two UN peacekeepers die in Haiti. Two Jordanian UN peacekeepers have been shot dead in the Haitian capital, Port-au-Prince, UN officials say. Americas. 11 Nov. 2006. Disponível em: http://news.bbc.co.uk/go/pr/fr//2/hi/americas/6139596.stm. Acesso em: 31 out. 2016.

BEAULIEU, Emily; HYDE, Susan D. "In the shadow of democracy promotion strategic manipulation, international observers, and election boycotts". Comparative Political Studies, v. 42, n. 3, p. 392-415, 2009.

BEIGBEDER, Yves. "Referendum". In: Max Planck Encyclopedia of Public International Law. Heidelberg: Max Planck Foundation for International Peace and the Rule of Law, 2011.

. International monitoring of plebiscites, referenda and national

elections: self-determination and transition to democracy. Leiden: Martinus Nijhoff Publishers, Vol. 32, 1994, 331 p.

BETTS, Richard K.; HUNTINGTON, Samuel P. "Dead dictators and rioting mobs: does the demise of authoritarian rulers lead to political instability?". International Security, v. 10, n. 3, p. 112-146, 1986.

BIRCH, Sarah. Electoral Malpractice. Oxford: Oxford University Press, 2011, $209 \mathrm{p}$. 
BJORNLUND, E. Beyond free and fair: Monitoring elections and building democracy. Washington: Woodrow Wilson Center Press, 2004, 408 p. 24, 2001.

"Democracy Inc." The Wilson Quarterly, v. 25, n. 3, (Summer), p. 18-

BØÅS, Morten. "Governance as multilateral development bank policy: The cases of the African development bank and the Asian development bank". The European Journal of Development Research, v. 10, n. 2, p. 117-134, 1998.

BONEO, Horacio. "La observación (internacional y nacional) de las elecciones". In: NOHLEN, Dieter et al (comp.). Tratado de derecho electoral comparado de América Latina. Mexico: Fondo de Cultura Económica, p. 1072-1109, 2007.

BOUTROS-GHALI, BOUTROS. Report of the Secretary-General. An Agenda for Peace - Preventive diplomacy, peacemaking and peace-keeping, UN doc. A/47/277-S/24111, 17 Junho 1992.

. Report of the Secretary-General. An Agenda for Development, UN doc. A/48/935, 6 Maio 1994.

. Report of the Secretary-General. An Agenda for Democratization, UN Doc. A/51/761, 20 Dezembro 1996.

BRUSIS, Martin. Developing Governance Capacity. A Review of Causes and Effects (Bertelsmann Foundation and Center for Applied Policy Research). Strategy Paper for the Transformation Thinkers Conference, Berlin, 30 November - 5 December 2003, 18 p.

BUENDÍA, Jorge; SOMUANO, Fernanda. Participación electoral en nuevas democracias: la elección presidencial de 2000 en México. Política y Gobierno, v. 10, n. 2, p. 289-322, 2003.

CALINGAERT, Daniel. "Election Rigging and How to Fight It". Journal of Democracy, v. 17, n. 3, p. 138-151, 2006.

CAMPBELL, David F. J. The basic concept for the democracy ranking of the quality of democracy. Vienna: Democracy Ranking, v. 10, 2008, 50 p.

CAROTHERS, Thomas. Aiding democracy abroad: The learning curve. Carnegie Endowment, 2011.

"The end of the transition paradigm". Journal of Democracy, v. 13, n. 1, p. 5-21, 2002.

. "The rising of election monitoring: the observers observed". Journal of Democracy, v. 8, n. 3, p. 17-31, 1997.

CARRILLO, Manuel. "Cooperación Internacional" In: NOHLEN, Dieter; ZOVATTO, Daniel; OROZCO, Jesús; THOMPSON, José (comp.). Tratado de derecho electoral comparado de América Latina. $2^{\mathrm{a}}$ ed. México: FCE, Instituto Interamericano de Derechos Humanos, Universidad de Heidelberg, International IDEA, Tribunal Electoral del Poder Judicial de la Federación, Instituto Federal Electoral, p. 84-106, 2007. 
CARROLL, David J.; DAVIS-ROBERTS, Avery. "The Carter Center and election observation: An obligations-based approach for assessing elections". Election Law Journal, v. 12, n. 1, p. 87-93, 2013.

CASTRO SANTOS, Maria Helena de. "Governabilidade, Governança e Democracia: Criação de Capacidade Governativa e Relações ExecutivoLegislativo no Brasil Pós-Constituinte". Dados [online]. 1997, v. 40, n. 3. Available from: http://www.scielo.br/scielo.php?script=sci arttext\&pid=S0011$\underline{52581997000300003 \& \operatorname{lng}=\text { en\&nrm=iso. }}$.

. "Que democracia? Uma visão conceitual desde a perspectiva dos países em desenvolvimento". Dados, v. 44, n. 4, p. 729-771, 2001.

CENTRO CARTER. "About". Elections Standards at the Carter Center. Acesso em: 20 set. 2016. Disponível em: http://electionstandards.cartercenter.org/about/.

. Final Report of the Electoral Observation Mission in Mexico. Democracy Program for Latin America and Caribbean, 1994.

The Carter Delegation to Observe the July 6, 1997 Elections in Mexico. Democracy Program for Latin America and Caribbean, 1997.

Observing the $\mathbf{2 0 0 0}$ Mexico Elections. Final Report. Latin American and Caribbean Program, 2001.

CEPALSTAT. Base de dados. Comissão Econômica para América Latina e Caribe, $2016 . \quad$ Disponível em: http://estadisticas.cepal.org/cepalstat/web cepalstat/Portada.asp?idioma=i. Acesso em: 28 nov. 2016.

CHAND, Vikram. "Democratisation from the outside in: NGO and International Efforts to Promote Open Elections". Third World Quarterly, v. 18, n. 3, p. 543 561, 1997.

Mexico's political awakening. Notre Dame, IN: University of Notre Dame, Dame Press, 2001, 392 p.

CHAUVET, Lisa; COLLIER, Paul. "Elections and Economic Policy in Developing Countries". Economic Policy, v. 24, n. 59, p. 509-550, July, 2009.

COLLIER, David; LEVITSKY, Steven. "Democracy with adjectives: Conceptual innovation in comparative research". World politics, v. 49 , n. 03 , p. 430-451, 1997.

COLLIER, Paul. The Bottom Billion: Why the Poorest Countries are Failing and What Can Be Done about It. Oxford: Oxford University Press, 2007, 224 p.

COMISSÃO EUROPEIA. EC Methodological Guide on Electoral Assistance. Bruxelas: EuropeAid Co-Operation Office, 2006, 237 p.

COMMISSION OF THE EUROPEAN COMMUNITIES. Communication from the Commission on EU Election Assistance and Observation. Disponível em: http://europa.eu.int/eurlex/en/com/cnc/2000/com2000 0191en01.pdf. Acesso em: 29 abril 2016. 
CONFLICT BAROMETER. Conflict Barometer 2015. Heidelberg Institute for International Conflict Research, Heildeberg, Germany, 2016.

CEP (CONSELHO ELEITORAL PROVISÓRIO). Liste des candidats à la Présidence confirmés - 2015. Porto Príncipe, 2015a.

. Liste des Partis Politiques agréés - 2015. Porto Príncipe, 2015b.

CORNELIUS, Wayne A. "La eficacia de la compra y coacción del voto en las elecciones mexicanas de 2000". Revista Perfiles Latinoamericanos, v. 10, n. 20, p. 11-31, 2002.

CRESPO, Jose Antonio. "Observadores internacionales: la percepción ciudadana", Documento de trabajo 3. Mexico City: CIDE, 1992.

CROCHETET, Mathilde. La sociogenèse de l'observation électorale international: le rôle des missions d'observation électorale internationale dans la promotion de la démocratie. Tese, Sciences Po Toulouse, Institut d'Études Poltiques, 2013, $102 \mathrm{p}$.

CRONIN, Bruce. "Self-Determination". In: BADIE, Bertrand; BERGSCHLOSSER, Dirk; MORLINO, Leonardo (eds). International encyclopedia of political science. Sage, p. 2394-2396, 2011.

DAHL, Robert. Poliarquia: participação e oposição. São Paulo: Editora USP, 2005, $240 \mathrm{p}$.

DALTON, Jennifer E. "Self-determination". In: KURIAN, George T. (ed.). The Encyclopedia of Political Science. Washington, D.C.: CQ Press, 2011, p. 1530.

DASH, Michael. "True Dechoukaj: Uprooting Bovarysme in Post-Duvalier Haiti". In: QUINN, Kate; SUTTON, Paul. Politics and power in Haiti. United States: Palgrave Macmillan, p. 27-42, 2013.

DAXECKER, Ursula; SCHNEIDER, Gerald. "Election monitoring: the implications of multiple monitors for electoral integrity". In: NORRIS, Pipa et al. (eds). Advancing Electoral Integrity. New York: Oxford University Press, p. 73-93, 2014.

DPIOE (DECLARAÇÃO DE PRINCÍCIOS DE OBSERVAÇÃO INTERNACIONAL ELEITORAL). Nações Unidas, 2005.

DEMMERS, Jolle et al. "Good Governance and democracy in a world of neoliberal regimes". In: DEMMERS, Jolle et al (eds). Good Governance in the Era of Global Neoliberalism Conflict and depolitisation in Latin America, Eastern Europe, Asia and Africa. New York: Routledge, 2005, Cap.1.

DIAMOND, Larry Jay. "Elecciones sin democracia: a proposito de los regímenes híbridos". Estudios Políticos, n. 24, Medellin, p. 117-134, 2004.

1996

"Is the third wave over?". Journal of Democracy, v. 7, n. 3, p. 20-37,

DONNO, Daniela. "Elections and democratization in authoritarian regimes".

American Journal of Political Science, v. 57, n. 3, p. 703-716, $2013 \mathrm{~b}$. 
. "Who is punished? Regional intergovernmental organizations and the enforcement of democratic norms". International Organization, v. 64, n. 04, p. 593-625, 2010.

Defending democratic norms: international actors and the politics of electoral misconduct. Oxford University Press, 2013a, 268 p.

DUPUY, Alex. "Haiti Election 2006: A Pyrrhic Victory for René Préval?". Latin American Perspectives, v. 33, n. 3, p. 132-141, 2006.

From François Duvalier to Jean-Bertrand Aristide: The Declining Significance of Color Politics in Haiti. In: QUINN, Kate; SUTTON, Paul. Politics and power in Haiti. United States: Palgrave Macmillan, p. 43-64, 2013.

EDGELL, Amanda B. et al. When and Where do Elections Matter? A Global Test of the Democratization by Elections Hypothesis, 1900-2012. Working Paper, University of Gothenburg, v. 8, Aug. 2015, 35 p.

EISENSTADT, Todd A. Courting democracy in Mexico: party strategies and electoral institutions. Cambridge University Press, 2003.

ELKLIT, Jørgen; REYNOLDS, Andrew. "A framework for the systematic study of election quality". Democratization, v. 12, n. 2, p. 147-162, 2005.

; SVENSSON, P. "What Makes Elections Free and Fair?". Journal of Democracy, v. 8, n. 3, p. 32-46, 1997.

EXECUTIVE ORDER. "Establishment of the Presidential Commission of Election Administration,", White House, 28 March 2013. Disponível em: https://www.whitehouse.gov/the-press-office/2013/03/28/executive-order-

establishment-presidential-commission-election-administr. Acesso em: 03 Maio 2016.

FIORI, José Luís. A governabilidade democrática na nova ordem econômica. Universidade de São Paulo, Instituto de Estudos Avançados, 1995.

FINNEMORE, Martha; SIKKINK, Kathryn. "International norm dynamics and political change". International organization, v. 52, n. 04, p. 887-917, 1998.

FLORES, Thomas. "Monitoring the Monitors: Understanding Election Observation in Today's World”. International Studies Review, v. 15, p. 432-437, 2013.

FOX, Gregory H.; ROTH, Brad R. Democratic governance and international law. United Kingdom: Cambridge University Press, 2000, 600 p.

FOX, Jonathan. "National electoral choices in rural Mexico". In: RANDALL, Laura (ed.) Reforming Mexico's Agrarian Reform. Armonk, NY: ME Sharpe, p. 185209, 1996.

FRANCK, Thomas M. "The Emerging Right to Democratic Governance". The American Journal of International Law, Vol. 86, No. 1 Jan., p. 46-91, 1992.

FREEDOM HOUSE. Freedom in the world 2015. Washington, DC e New York, 2015a. Disponível em: https://freedomhouse.org/report/freedom-world/freedomworld-2015. Acesso em: 14 out. 2016. 
Freedom in the world 2016. Electoral Democracies: Freedom in the World 1989-90 to 2016. Washington, DC e New York, 2016. Disponível em: https://freedomhouse.org/sites/default/files/Electoral\%20Democracy\%20Table, \%20"Yes-No"\%20list,\%20FIW\%201989-2016.xIsx. Acesso em: 23 out. 2016.

. Methodology. Washington, DC e New York, 2015b. Disponível em: https://freedomhouse.org/report/freedom-world-2015/methodology. Acesso em: 23 out. 2016.

FREIDENBERG, Flavia. ¡En el Jardín de las Delicias! Los Informes de las Misiones de Observación Electoral como una herramienta para evaluar las elecciones en América Latina. Conferencia Global de la Asociación Mundial de Organismos Electorales (AWEB), Santo Domingo y Punta Cana, 27 octubre 2015, 28 p.

"Oportunistas, idealistas y adversarios en el proceso de reforma electoral en México (2007-2008)". Revista Justicia Electoral, v. 1, n. 5, p. 525531, 2010.

FSI (FRAGILE STATES INDEX). Fragile States Index 2016: The Book. Washington, DC: The Fund for Peace, 2016.

GANDHI, Jennifer; LUST-OKAR, Ellen. "Elections under authoritarianism". Annual Review of Political Science, v. 12, p. 403-422, 2009.

GAUTHIER, Amélie; MOITA, Madalena. Vulnerability and causes of fragility in Haiti. Spain: Fride, 2010, 12 p.

GEISLER, Gisela. "Fair? What Has Fairness Got to Do with It? Vagaries of Election Observations and Democratic Standards". The Journal of Modern African Studies, v. 31, n. 4, pp 613-637, 1993.

GIBBRAN, Montero. Visitantes extranjeros: Evolución y retos de la observación electoral internacional. Caso de México. V Congreso Latinoamericano de Ciencia Política. Asociación Latinoamericana de Ciencia Política, Buenos Aires, 2010, 20 p.

GOODWIN-GILL, Guy S. Free and fair elections. Inter-Parliamentary Union, Geneva, 2006, 214 p.

GREENE, Kenneth F. Why dominant parties lose: Mexico's democratization in comparative perspective. Cambridge University Press, 2007.

HABER, Stephen H. et al. Mexico since 1980. Cambridge: Cambridge University Press, 2008.

HARTLYN, Jonathan; MCCOY, Jennifer. "Observer Paradoxes: How to Assess Electoral Manipulation". In: SCHEDLER, Andreas (ed.). Electoral Authoritarianism: The Dynamics of Unfree Competition. Boulder: Lynne Rienner, p. 41-54, 2006.

; MUSTILLO, Thomas M. "Electoral Governance Matters: Explaining the Quality of Elections in Contemporary Latin America". Comparative Political Studies, v. 41, n. 1, p. 73-98, 2008. 
HERZ, Monica; HOFFMANN, Andrea R. Organizações Internacionais: histórias e práticas. Rio de Janeiro: Elsevier, 2004.

HOLZNER, Claudio. "Mexico: Weak State, Weak Democracy". In: LEVINE, Daniel $\mathrm{H}$.; MOLINA, José Enrique (Ed.). The quality of democracy in Latin America. Boulder, CO: Lynne Rienner Publishers, p. 83-110, 2011.

HOYOS, Irma Méndez de. Exploring the determinants of Electoral Mal Practices in Presidential Elections in Latin America 2006-2012. 23rd World Congress of Political Science IPSA, July 19-24, Montréal, Canada, 2014, 25 p.

; LOZA, Nicolas. Instituciones electorales, opinión pública y poderes políticos locales en México. FLACSO Mexico/CLACSO, 2014.

. "De la hegemonía a la competitividad electoral: la transición democrática en México, 1979-2003". Revista Española de Ciencia Política, n. 9, p. 113-142, 2003.

HUNTINGTON, Samuel P. "Democracy's third wave". Journal of Democracy, v. 2, n. 2, p. 12-34, 1991.

A Terceira Onda. A democratização no final do século XX. São Paulo: Ática, 1994, 335 p.

HYDE, Susan D. "How International Election Observers Detect and Deter Election Fraud." In ALVAREZ, R.; HALL, Thad E. e HYDE, Susan D. (eds). Election Fraud: Detecting and Deterring Electoral Manipulation, Washington, DC: Brookings Institution Press, p. 201-215, 2008.

. "The observer effect in international politics: Evidence from a natural experiment". World Politics, v. 60, n. 01, p. 37-63, 2007. 2011, $248 \mathrm{p}$.

The Pseudo-democrat's Dilemma. Cornell University Press, Ithaca,

.; MARINOV, Nikolay. "Information and self-enforcing democracy: The role of international election observation". International Organization, v. 68, n. 02, p. 329-359, 2014.

.; MARINOV, Nikolay. "Which Elections Can Be Lost?", Political Analysis, v. 20, n. 2, p. 191-201, 2012.

.; O'MAHONY, Angela. "International scrutiny and pre-electoral fiscal manipulation in developing countries". The Journal of Politics, v. 72, n. 03, p. 690-704, 2010.

. Explaining the causes and consequences of internationally monitored elections. Tese. Universidade da California, San Diego, Estados Unidos, 2006, $277 \mathrm{p}$.

.; KELLEY, Judith; NIELSEN, Daniel. The sources of perceived legitimacy for election observation organizations: three experiments on non-governmental organizations. International Studies Association Annual Meeting, Georgia, 16-19 March, 2016, 68 p. 
ICHINO, Nahomi; SCHÜNDELN, Matthias. "Deterring or displacing electoral irregularities? Spillover effects of observers in a randomized field experiment in Ghana". The Journal of Politics, v. 74, n. 01, p. 292-307, 2012.

IDEA (INTERNATIONAL INSTITUTE FOR DEMOCRACY AND ELECTORAL ASSISTANCE). Electoral Management Design: Revised edition. Sweden, 2014.

International electoral standards: Guidelines for reviewing the legal framework of elections. Stockholm, 2002.

IFES (INTERNATIONAL FOUNDATION FOR ELECTORAL SYSTEMS). Ifes Election Guide. United States: Washington, 2016.

Election Observation Final Report Mexico, 1994.

1997 Federal Elections in Mexico: a general overview, 1997.

INE (INSTITUTO NACIONAL ELEITORAL). Atlas de Resultados Electorales Federales 1991-2012. Sistema de Consulta de la Estadística de las Elecciones Federales. Disponível em: http://siceef.ife.org.mx/. Acesso em: 27 out. 2016.

IPU (INTER-PARLIAMENTARY UNION). Declaration on Criteria for free and fair Elections Unanimously adopted by the Inter-Parliamentary Council in Paris, 26 March 1994.

. Universal Declaration on Democracy Unanimously adopted by the Inter-Parliamentary Union in Cairo, 16 September 1997.

IRI (INTERNATIONAL REPUBLICAN INSTITUTE). Haiti: Election Observation Report. Washington: IRI, 1990.

Haiti: Election Observation Report. Washington: IRI, 1995.

Haiti: Election Observation Report. Washington: IRI, 1997.

Election Observation Mission Report Mexico. Washington, IRI, 2000.

Election Observation Mission Report Mexico. Washington, IRI, 2006.

ISO (ORGANIZAÇÃO INTERNACIONAL PARA A PADRONIZAÇÃO/COMITÊ TÉCNICO (TC). Quality management systems. Particular requirements for the application of ISO 9001: 2008 for electoral organizations at all levels of government. Suíça: Genebra, 2014.

JASON, Karen J. "Role of Non-Governmental Organizations in International Election Observing". The NYU Journal of International International Law \& Politics, v. 24, p. 1795-1843, 1991.

JOHNSTON, Jake; WEISBROT, Mark. Haiti's Fatally Flawed Election. Center for Economic and Policy Research, 2011, 15 p.

KANT, Immanuel. A Paz Perpétua (1795). Coleção L\&PM Pocket, 96 p., 2008.

KARL, Terry Lynn. "Dilemmas of democratization in Latin America". Comparative Politics, v. 23, n. 1, p. 1-21, 1990. 
. "The hybrid regimes of Central America". Journal of Democracy, v. 6, n. 3, p. 72-86, 1995.

KAUFMANN, Daniel; KRAAY, Aart; MASTRUZZI, Massimo (2010). "The Worldwide Governance Indicators: Methodology and Analytical Issues". World Bank Policy Research Working Paper No. 5430, 2010.

KEESING'S RECORD OF WORLD EVENTS. "Fall of Duvalier government", 01 Jan. 1986. Volume 32, Issue No. 12 (December), Page 34158, 1986.

. "Opposition protests General elections Swearing in of civilian President", 01 Fev. 1988. Volume 34, Issue No. 2 (February), Page 35695, 1988.

. "Postponement of general election", 09 Jan 1990. Volume 36, Issue No. 12 (December), Page 37708, 1990.

"Presidential elections", 01 Dec 1990. Volume 36, Issue No. 12 (December), Page 37911, 1990.

KEKIC, Laza. The Economist Intelligence Unit's index of democracy. The Economist, v. 21, p. 1-11, 2015.

KELLEY, Judith. "Assessing the complex evolution of norms: the rise of international election monitoring". International Organization, v. 62, n. 02, p. 221-255, 2008.

"The more the merrier? The effects of having multiple international election monitoring organizations". Perspectives on Politics, v. 7, n. 01, p. 5964, 2009.

Monitoring Democracy: When International Election Observation Works and Why It Often Fails. Princeton University Press, Princeton, NJ, 2012a, $336 \mathrm{p}$.

The Good, the Bad, and the Ugly: Rethinking Election Monitoring. Stockholm. Sweden: International IDEA, 2012b, 19 p.

KENKEL, Kai Michael. Five generations of peace operations: from the "thin blue line" to "painting a country blue". Revista Brasileira de Política Internacional, Brasília, v. 56, n. 1, p.122-143, 2013.

KLESNER, Joseph L. "Adiós to the PRI? Changing Voter Turnout in Mexico's Political Transition". Estudios Mexicanos, v. 17, n. 1, p. 17-39, 2001.

KUMAR, Krishna. Post-conflict elections and international assistance.: Postconflict Elections, Democratization, and International Assistance. Boulder: Lynne Rienner Publishers, 1998, 270 p.

LANSFORD, Tom. "Democracy, future of". In KURIAN, George T. (ed.), The Encyclopedia of Political Science. Washington, D.C.: CQ Press, p. 391 - 392, 2011a.

"Election Monitoring". In KURIAN, George T. (ed.), The Encyclopedia of Political Science. Washington, D.C.: CQ Press, p. $478-479,2011 \mathrm{~b}$. 
LAPPIN, Richard. "Why Observe Elections? Reassessing the Importance of Credible Elections to Post-Conflict Peacebuilding". Peace Research, v. 41, n. 2, p. 85-117, 2009.

LATINOAMERICANA. "Haiti". Enciclopédia contemporânea da América Latina e do Caribe. São Paulo; Buenos Aires: Boitempo Editorial, p. 643-651, 2007.

. "México". Enciclopédia contemporânea da América Latina e do Caribe. São Paulo; Buenos Aires: Boitempo Editorial, p. 759-779, 2007.

LATINOBAROMETRO. Latinobarómetro Análisis de datos. Chile: Providencia Santiago, 2015.

LEAN, Sharon. "External Validation and Democratic Accountability". In: LEGLER, Thomas; LEAN, Sharon; BONIFACE, Dexter (Eds). Promoting Democracy in the Americas. Baltimore, The Johns Hopkins University Press, p. 152-174, 2007.

. Civil Society and Electoral Accountability in Latin America. New York: Palgrave Macmillan, 2012, $196 \mathrm{p}$.

LEDUC, Lawrence; NIEMI, Richard G.; NORRIS, Pipa. Comparing Democracies. Elections and voting in a Changing World. Sage Publications, 2014, 256 p.

LEGLER, Thomas F.; LEAN, Sharon F.; BONIFACE, Dexter S. Promoting democracy in the Americas. John Hopkins University Press, 2007, 338 p.

LEININGER, Julia. "Bringing the Outside in': Illustrations from Haiti and Mali for the Re-conceptualization of Democracy Promotion”. Contemporary Politics, v. 16, n. 1, p. 63-80, 2010.

LEVITSKY, Steven; WAY, Lucan A. Competitive authoritarianism: Hybrid regimes after the cold war. Cambridge University Press, 2010, 536p.

.; . "The rise of competitive authoritarianism". Journal of Democracy, v. 13, n. 2, p. 51-65, 2002.

LINDBERG, Staffan (ed.). Democratization by elections: a new mode of transition. Baltimore: Johns Hopkins University Press, 2009, 432 p.

. Democracy and elections in Africa. JHU Press, 2006, 221 p.

LIPSET, S. M. "Some Social Requisites of Democracy: Economic Development and Political Legitimacy." American Political Science Review, n. 53, p. 69-105, 1959.

LUDWIG, Robin. "Processes of democratization: the new role of the United Nations in electoral assistance". The Ecumenical Review, 01 July, 1995, 5p.

MAGALONI, Beatriz. Voting for autocracy: Hegemonic party survival and its demise in Mexico. Cambridge: Cambridge University Press, 2006.

MAGEN, A.; MORLINO, L. (eds) International Actors, Democratization, and the Rule of Law: Anchoring Democracy? London: Routledge, 2008, 291 p. 
; RISSE, T.; MCFAUL, M. (eds). Promoting Democracy and the Rule of Law. New York: Palgrave Mcmillan, 2009, 281 p.

MAINWARING, Scott P.; HAGOPIAN, Frances (eds.). The third wave of democratization in Latin America: advances and setbacks. Cambridge University Press, 2005.

MATHEWS, Jessica T. "Power shift". Foreign Affairs, p. 50-66, 1997.

MCCONNELL, Shelley A. "The 2011 presidential and legislative elections in Nicaragua". Electoral Studies, v. 34, p. 300-303, 2013.

MCCOY, Jennifer. "Monitoring and Mediating Elections During Latin American Democratization". In: MIDDLEBROOK, Kevin (ed.). Electoral Observation and Democratic Transitions in Latin America. San Diego: Center for US - Mexican Studies, University of California, p. 53-90, 1998.

.; PASTOR, Robert A.; GARBAR, Larry. "Pollwatching and peacemaking". Journal of Democracy, v. 2, n. 4, p. 102-114, 1991.

.; HARTLYN, Jonathan. "The relative powerlessness of elections in Latin America. Democratization by elections: A new mode of transition". In: LINDBERG, Staffan (ed.). Democratization by elections: a new mode of transition. Baltimore: Johns Hopkins University Press, p. 47-76, 2009.

.; MCCARTHY, Michael. Electoral Legitimacy and International Norms: Repercussions of the April, 2013 Venezuelan Presidential Elections. Paper prepared for the XXI International Congress of the Latin American Studies Association. Washington, DC, May 29-June 1, 2013.

.; MCCONNEL, Shelley; MCCARTHY, Michael. ¿Desafiando la norma? Acompañamiento Electoral Internacional en Nicaragua y Venezuela. América Latina Hoy, n. 70, p. 109-132, 2015.

MCFAUL, Michael. "Transitions from postcommunism". Journal of Democracy, v. 16, n. 3, p. 5-19, 2005.

MEARSHEIMER, John J. "A Realist Reply." International Security, v. 20, n. 1, p. 82-93, 1995.

Por que os líderes mentem: toda a verdade sobre as mentiras na política internacional. São Paulo: Zahar, 2012, 179 p.

MERLOE, Patrick. "Authoritarianism Goes Global: Election Monitoring Vs. Disinformation”. Journal of Democracy, v. 26, n. 3, p. 79-93, 2015.

Promoting Legal Frameworks for Democratic Elections: An NDI Guide for Developing Election Laws and Law Commentaries, 2008, 162 p.

MOZAFFAR, Shaheen. "Patterns of Electoral Governance in Africa's Emerging Democracies". International Political Science Review, v. 23, n. 1, p. 85-101, 2002.

.; SCHEDLER, Andreas. "The Comparative Study of Electoral Governance - Introduction", International Political Science Review, v. 23, n.1, p. 5-27, 2002. 
MUNCK, Gerardo L.; VERKUILEN, Jay. "Conceptualizing and measuring democracy Evaluating alternative indices". Comparative Political Studies, v. 35, n. 1, p. 5-34, 2002.

MUÑOZ-POGOSSIAN, Betilde; VELOSO, David Álvarez. "La Responsabilidad de Observar: Repensando la Observación Electoral de la OEA". América Latina Hoy, v. 70, p. 55-76, 2015.

NANDA, Ved P. The "good governance" concept revisited. The Annals Of The American Academy of Political and Social Science, v. 603, n. 1, p. 269-283, 2006.

NDI e NRIIA. Toward a Democratic Haiti: A Report on the Constitutional Referendum of March 29, 1987 and the Electoral Process in Haiti, 1987.

NRIIA (NATIONAL REPUBLICAN INSTITUTE FOR INTERNATIONAL AFFAIRS). The 1990 Elections in Haiti: Report of the International Election Observer Delegation. Washington: NRIIA, 1990.

NELSON, Sue. Haitian Elections and the Aftermath. In: KUMAR, Krishna. Post conflict elections and international assistance. Post conflict Elections, Democratization, and International Assistance, United Kingdom: Lynne Rienner Publishers, v. 6, p. 71-86, 1998.

NEVITTE, Neil; CANTON, Santiago A. "The role of domestic observers". Journal of Democracy, v. 8, n. 3, p. 47-61, 1997.

NICHOLLS, David. The Duvalier Regime in Haiti. In: CHEHABI, Houchang E.; LINZ, Juan J. Sultanistic regimes. JHU Press, p. 153-181, 1998.

NORRIS, Pippa et al. The Electoral Integrity Project: The Year in Elections, 2015.

NORRIS, Pippa. "Does the world agree about standards of electoral integrity? Evidence for the diffusion of global norms". Electoral Studies, v. 32, n. 4, pp 576 $-588,2013 b$.

"The new research agenda studying electoral integrity". Electoral Studies, v. 32, n. 4, p. 563-575, 2013a.

. Why electoral malpractices heighten risks of electoral violence. In: APSA 2012 Annual Meeting Paper, p. 1-31, 2012.

.; FRANK, Richard W.; I COMA, Ferran Martínez. "Assessing the quality of elections". Journal of Democracy, v. 24, n. 4, p. 124-135, 2013.

O'DONNELL, Guillermo; SCHMITTER, Philippe C.; WHITEHEAD, Laurence. Transitions from authoritarian rule: comparative perspectives. JHU Press, 1986, $208 \mathrm{p}$.

OCDE (ORGANIZAÇÃO PARA A COOPERAÇÃO E DESENVOLVIMENTO ECONÔMICO). Participatory Development and Good Governance, Paris: OECD, 1995.

Principles for good international engagement in fragile states and situation. Paris: Development Assistance Committee (DAC), 2007, 4 p. 
OEA (ORGANIZAÇÃO DOS ESTADOS AMERICANOS). AG/RES. 1063 (XX$0 / 90)$. Unit for the Promotion of Democracy. $8^{\text {th }}$ June 1990. June 1990.

AG/RES. 1063 (XX-0/90). Unit for the Promotion of Democracy. $8^{\text {th }}$

. Carta Democrática Interamericana: documentos e interpretaciones. Washington, DC, 2003, 350p.

. Final Report of the Electoral Observation Mission in Haiti. Secretary General, 2000.

. Final Report of the Electoral Observation Mission in Haiti. Secretary General, 2006.

Final Report of the Electoral Observation Mission in Haiti. Secretary General, 2015.

. OAS Report of the Secretary General on the Organization's Support for the Electoral Process in Haiti. Washington: OEA, 1992.

OEA: 50 años observando elecciones en las Américas. Departamento para la Cooperación y Observación Electoral, 2012, 18 p.

Rapport sur la mission d'observation des elections presidentielles. Washington: OEA, 2015.

Report of the Joint Electoral Observation Mission of the Organization of American States (OAS) and the Caribbean Community (CARICOM): Presidential and Legislative Elections: First and Second Rounds: Republic of Haiti: November 28, 2010, and March 20, 2011, Department for Electoral Cooperation and Observation, 2010.

Informe final de la misión de observación electoral de la OEA sobre el proceso electoral federal del 5 de julio de 2009 celebrado en los Estados Unidos Mexicanos. Secretaría de Asuntos Políticos, 2009.

. Informe final de la misión de observación electoral de la OEA sobre el proceso electoral federal del 1 de julio de 2012 celebrado en los Estados Unidos Mexicanos. Secretaría de Asuntos Políticos, 2012.

Informe final de la misión internacional de la OEA para presenciar las elecciones federales de diputados del 5 de junio de 2015 en los Estados Unidos Mexicanos. Secretaría de Asuntos Políticos, 2015.

OIF (ORGANISATION INTERNATIONALE DE LA FRANCOPHONIE). Rapport de la mission francophone d'observation des elections, 2006.

ONU (ORGANIZAÇÃO DAS NAÇÕES UNIDAS). Carta das Nações Unidas, Capítulo VII, 1945.

"Electoral Assistance". Department of Political Affairs. 2016. Disponível em: http://www.un.org/undpa/en/overview. Acesso em: 10 ago 2016.

. Convenção para Eliminação de Todas as Formas de Discriminação contra Mulheres. Assembleia Geral. Estados Unidos: Washington, 1979. 
Geral, 1948.

Declaração Universal de Direitos Humanos (DUDH). Assembleia

. Declaration of Principles for International Election Observation and Code of Conduct for International Election Observers. United Nations, New York, 27 October, 2005.

Pacto Internacional sobre Direitos Civis e Políticos (ICCPR). Assembleia Geral, 1968. 1995.

Plataforma de Ação de Beijing. Assembleia Geral. China: Pequim,

. Resolução 45/150. Assembleia Geral, 1991.

Resolution 742 (VIII): factors which should be taken into account in deciding whether a territory is or is not a territory whose people not yet attained a full measure of self-government, Assembleia Geral, 1953.

PADILLA, David; HOUPPERT, Elizabeth. "International election observing: enhancing the principle of free and fair elections". Emory International Law Review, v. 7, p. $73-132,1993$.

PE (PARLAMENTO EUROPEU). Observer's Report on the Elections. Delegation of observers to Mexico for the federal elections of 2 July 2000. Committee on Foreign Affairs, Human Rights, Common Security and Defence Policy, 2000.

PASTOR, Robert A. "Elections, monitoring". Encyclopedia of Democracy, Washington, DC: Congressional Quarterly, 1995, p. 409.

1998.

"Mediating elections". Journal of Democracy, v. 9, n. 1, p. 154-163,

"Post-revolutionary Mexico: The salinas opening". Journal of Interamerican Studies and World Affairs, v. 32, n. 3, p. 1-22, 1990.

. Not condemned to repetition: The United States and Nicaragua. Boulder: Westview, 2002, $448 \mathrm{p}$.

"The Third Dimension of Accountability: The Role of the International Community in National Elections,". In: SCHEDLER, Andreas; DIAMOND, Larry, PLATTNER, Marc F. (eds). The Self-Restraining State: Corruption and Accountability in New Democracies. Boulder, CO: Lynne Rienner, p.123-44, 1999.

PEREIRA, Lucilia. Free and Fair: The Politicization of Election Monitoring Reports. Thesis. Department of Political Studies of the University of Saskatchewan, Saskatoon, 2006.

PNUD (PROGRAMA DAS NAÇÕES UNIDAS PARA O DESENVOLVIMENTO). Relatório do Desenvolvimento Humano. $O$ trabalho como motor do desenvolvimento humano. Adis Abeba, Etiópia, Pnud, 2015.

1997, p. 2-3.

Governance for Sustainable Human Development, New York: UNDP, 
York, 2015.

Human Development Report 2015. Oxford University Press, New

PROTOCOLO DE QUITO. Protocolo de Quito. Associação de Organismos Eleitorais da América Central e do Caribe. Costa Rica: San José, 1989. Disponível em: https://www.iidh.ed.cr/capel2016/media/1091/acta-constitutivade-quito.pdf. Acesso em: 21 out. 2016.

PROTOCOLO DE TIKAL. Protocolo de Tikal. Associação de Organismos Eleitorais da América Central e do Caribe. Guatemala: Tikal, 1985. Disponível em: https://www.iidh.ed.cr/multic/UserFiles/Biblioteca/CAPEL/2 2010/0ea3fe6a636b-4df8-be6c-aca9b981e17c.pdf. Acesso em: 21 out. 2016.

PROTOCOLO DE WASHINGTON. Protocolo de Washington. Protocolo de Reforma da Carta da Organização dos Estados Americanos. Estados Unidos: Washington, 1992.

PRZEWORSKI, A. "Acquiring the Habit of Changing Governments Through Elections". Comparative Political Studies, v. 48, n. 1, p. $101-129,2015$.

QUEZADA, Sergio A. El financiamiento extranjero y la transición democrática mexicana: El caso de Alianza Cívica, 2001.

RECONDO, David. "Tailleurs de démocratie: l'assistance électorale de l'ONU racontée par ses artisans". In : BARÉ, Jean François. Paroles d'experts: Etudes sur la pensée institutionnelle du développement. KARTHALA Editions, p. 29-60, 2006.

REISMAN, W. Michael. "International Election Observation". Pace Yearbook of International Law, v. 4, 1992, 48 p.

REUS-SMIT, Christian. Individual Rights and the Making of the International System. Cambridge: Cambridge University Press, 2013, 248 p.

RISSE, Thomas; ROPP, Stephen C.; SIKKINK, Kathryn (eds). The power of human rights: International Norms and Domestic Change. United Kingdom: Cambridge, 1999, 336 p.

"Let's Argue!" Communicative Action in International Relations". International Organization, v. 54, n. 1, pp 1-39, 2000.

ROESSLER, Phillip G.; HOWARD, Marc M. "Post-Cold War Political Regimes: When Do Elections Matter?". In: LINDBERG, Staffan (ed.). Democratization by elections: a new mode of transition. Baltimore: Johns Hopkins University Press, p. 101-127, 2009.

ROSE, Richard. "Governability". In KURIAN, G. T. et al, International Encyclopedia of Political Science. Washington, D.C.: CQ Press, p. 686 - 687, 2010.

ROXBOROUGH, lan. "México". In: BETHELL, Leslie; ROXBOROUGH, lan. A América Latina entre a Segunda Guerra Mundial e a Guerra Fria. Paz e Terra, p. 265-302,1996.

RUSTOW, Dankwart. "Transitions to Democracy: Toward a Dynamic Model." Comparative Politics, v. 2, p. 337-363, 1970. 
SANTA-CRUZ, Arturo. "Constitutional structures, sovereignty, and the emergence of norms: The case of international election monitoring". International Organization, v. 59, n. 03, p. 663-693, 2005.

. "Election Monitoring and the Western Hemisphere Idea". In: LEGLER, Thomas; LEAN, Sharon; BONIFACE, Dexter (eds.). Promoting Democracy in the Americas. Baltimore, The Johns Hopkins University Press, p. 133-151, 2007.

. "Contested Compliance in a Liberal Normative Structure-The Western Hemisphere Idea and the Monitoring of the Mexican Elections". Journal of International Law \& International Relations, v. 5, p. 49-92, 2009.

International Election Monitoring, Sovereignty, and the Western Hemisphere: The Emergence of an International Norm. New York: Routledge, 2013, $304 \mathrm{p}$.

SARTORI, Giovanni. "Concept Misformation in Comparative Politics". The American Political Science Review, v. 64, n. 4, p. 1033-1053, 1970.

SCHEDLER, Andreas (ed.). Electoral authoritarianism: The dynamics of unfree competition. Boulder, CO: Lynne Rienner, 2006, 260 p.

. "Elections without democracy: The menu of manipulation". Journal of Democracy, v. 13, n. 2, p. 36-50, 2002a.

"The nested game of democratization by elections". International Political Science Review, v. 23, n. 1, p. 103-122, 2002b.

The politics of uncertainty: Sustaining and subverting electoral authoritarianism. OUP Oxford, 2013.

"Distrust Breeds Bureaucracy: Democratization and the Formal Regulation of Electoral Governance in Mexico". Public Integrity, v. 3, n. 2, 181199, 2001.

SCHERLEN, Renee G. "Lessons to build on: The 1994 Mexican presidential election". Journal of Interamerican Studies and World Affairs, v. 40, n. 1, 1998, p. 19-38.

SCHMITTER, Philippe C.; KARL, Terry Lynn. "What democracy is... and is not". Journal of Democracy, v. 2, n. 3, p. 75-88, 1991.

SCHUMPETER, Joseph A. Capitalismo, socialismo e democracia. Trad. de Ruy Jungmann. Rio de janeiro: Jorge Zahar, 1961, 487p.

SEBUDUBUDU, David. "Election observation". In: BADIE, Bertrand; BERGSCHLOSSER, Dirk; MORLINO, Leonardo (eds). International encyclopedia of political science. Sage, p. 722-724, 2011.

SELIGSON, Mitchell A.; BOOTH, John A. (Ed.). Elections and democracy in Central America, revisited. UNC Press Books, 1995, $312 \mathrm{p}$.

SERRA, Gilles. "The Risk of Partyarchy and Democratic Backsliding". Taiwan Journal of Democracy, v. 8, n. 1, p. 31-56, 2012. 
SHAW, Carolyn. "The United States: Rethoric and Reality". In: LEGLER, Thomas; LEAN, Sharon; BONIFACE, Dexter (eds.). Promoting Democracy in the Americas. Baltimore, The Johns Hopkins University Press, p. 63-84, 2007.

SHENON, Philip. Quayle Warns Haiti to Hold Fair Election. New York Times. World. Americas. 10 de agosto de 1990. Disponível em: http://www.nytimes.com/1990/08/10/world/quayle-warns-haiti-to-hold-fairelection.html. Acesso em: 30 out 2016.

SILVAYN, Patrick. "The Macoutization of Haitian Politics". In: QUINN, Kate; SUTTON, Paul. Politics and power in Haiti. United States: Palgrave Macmillan, p. $65-90,2013$.

SIMPSER, Alberto. "Unintended Consequences of Election Monitoring". In ALVAREZ, R.; HALL, Thad E. e HYDE, Susan D. (eds). Election Fraud: Detecting and Deterring Electoral Manipulation, Washington, DC: Brookings Institution Press, p. 201-215, 2008.

; DONNO, Daniela. "Can international election monitoring harm governance?". The Journal of Politics, v. 74, n. 02, p. 501-513, 2012.

STOKES, Geoffrey. "Democracy and citizenship". In ; CARTER, A. F.; Democratic theory today: challenges for the 21 st century. Blackwell Publishers, p. 23-51, 2001.

TAFT-MORALES, Maureen. Haiti's National Elections: Issues, Concerns, and Outcome. Current Politics and Economics of South and Central America, v. 4, n. 4, 2011.

TOSTENSEN, Arne; FABER, Doeke; JONG, Karijn de. Vers une approche intégrée de l'observation des élections? La professionnalisation des missions d'observation des élections de longue durée. Policy Management Report. Maastricht: European Centre for Development Policy Management, n. 7, 1997.

TRATADO DE PARIS. Tratado de Paris. França: Paris, 1856.

UE (UNIÃO EUROPEIA). Rapport sur la mission d'observation electoral Haiti 2015. Elections générales, 2015.

. Misión de Observación Electoral Unión Europea, México. Elecciones presidenciales y legislativas, 2006.

Report on the Election Observation Mission Mexico 2012. General Elections, 2012.

Report on the Election Observation Mission Mexico 2015. Legislative and Municipal Elections, 2015.

UNIORE (UNIÃO INTERAMERICANA DE ORGANISMOS ELEITORAIS). Acta Constitutiva. União Interamericana de Organismos Eleitorais. 1991. Disponível em: https://www.iidh.ed.cr/capel2016/media/1367/acta-constitutivade-la-union-interamericana.pdf. Acesso em: 11 ago 2016.

UNISDR (UNITED NATIONS INTERNATIONAL STRATEGY FOR DISASTER REDUCTION). Living with Risk: A Global Review of Disaster Reduction Initiatives. Preliminary Version. Geneva, Switzerland: Inter-Agency Secretariat of 
the International Strategy for Disaster Reduction. 382 pp, 2004. Disponível em: http://www.unisdr.org/eng/about isdr/bd-lwr-2004-eng.htm. Acesso em: 31 out. 2016.

VASAK, Karel. Reflexion sur l'observation international des eléctions. Symposium International de Bamako, Mali, p. 299-306, 2000.

WALECKI, Marcin et al. Political Finance in Post-Conflict Societies. Ifes: Center for transitional and post-conflict governance, 2006, $131 \mathrm{p}$.

WANBAUGH, Sarah. A monograph on plebiscites: with a collection of official documents. New York: Oxford University Press, 1920.

WEISS, Thomas G. "Governance, good governance and global governance: Conceptual and actual challenges". Third World Quarterly, v. 21, n. 5, p. 795814, 2000.

WENDT, Alexander. "Anarchy is what States Make of it: The Social Construction of Power Politics." International Organization (Cambridge Journals) v. 46, n. 2, p. 391-425, 1992.

WHITEHEAD, L. "Democratization with the benefit of hindsight: The changing international components". In: NEWMAN, E.; RICH, R. (eds). The UN Role in Promoting Democracy: Between Ideals and Reality. Tokyo, New York, Paris: UN University Press, p. 135-65, 2004. 